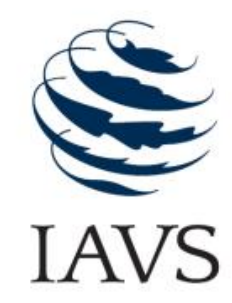

(

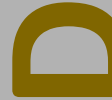

2

음

42

の

ง

$\circlearrowleft$

E

10

7

象

(1)

U

$\cup \frac{5}{6 \cdot \frac{\pi}{4}}$

F

U

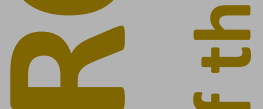

$<\div$

-

山.

4 흥

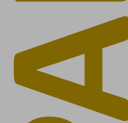

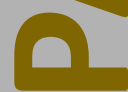

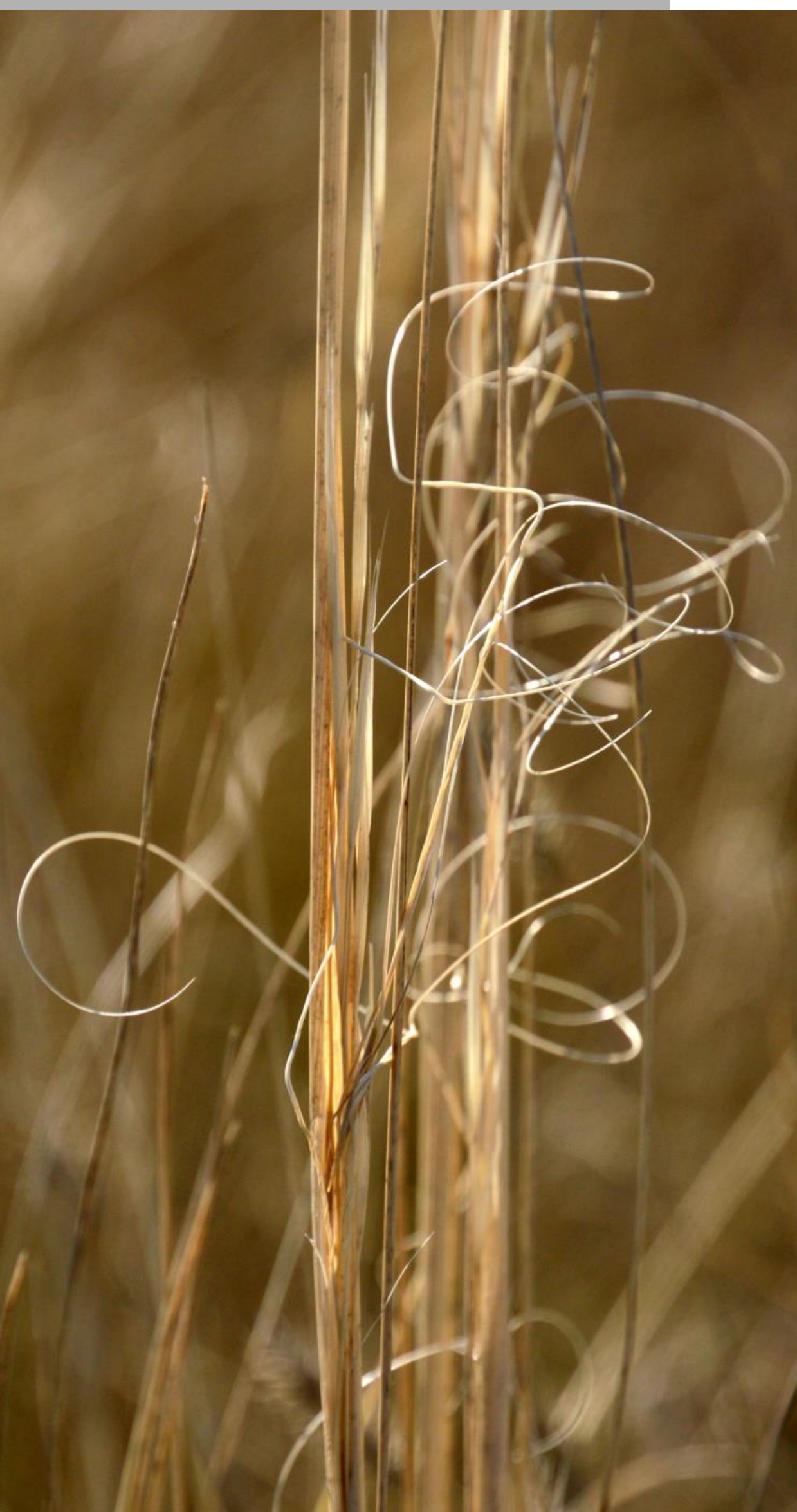




\section{Table of Contents}

Editorial

News

EDGG Publications

Dengler et al.: Sampling multiscale and multi-taxon plant diversity data in the subalpine and alpine habitats of Switzerland: Report on the 14th EDGG Field Workshop

Photo Stories

Glimpses of a Grassland

Photo competition

Short Contributions

Book Review

Recent Publications of our Members

Forthcoming Events

\section{Palaearctic Grasslands}

ISSN 2627-9827

DOI 10.21570/EDGG.PG47

Palaearctic Grasslands, formerly published under the names Bulletin of the European Dry Grassland Group (Issues 1-26) and Bulletin of the Eurasian Dry Grassland Group (Issues 27-36) is the journal of the Eurasian Dry Grassland Group (EDGG). It usually appears in four issues per year. Palaearctic Grasslands publishes news and announcements of EDGG, its projects, related organisations and its members. At the same time it serves as outlet for scientific articles and photo contributions.

Palaearctic Grasslands is sent to all EDGG members and, together with all previous issues, it is also freely available at http://edgg.org/publications/bulletin.

All content (text, photos, figures) in Palaearctic Grasslands is open access and available under the Creative Commons license CC-BY-SA 4.0 that allow to re-use it provided proper attribution is made to the originators ("BY") and the new item is licensed in the same way ("SA" = "share alike").

Scientific articles (Research Articles, Reviews, Forum Articles, Scientific Reports) should be submitted to Jürgen Dengler (dr.juergen.dengler@gmail.com), following the Author Guidelines updated in Palaearctic Grasslands 45: 4. They are subject to editorial review, with one member of the Editorial Board serving as Scientific Editor and deciding about acceptance, necessary revisions or rejection.

All other text contributions (News, Announcements, Short Contributions, Book Reviews, Glimpses of a Grassland...) should be submitted to Anna Kuzemko (anyameadow.ak@gmail.com) AND Idoia Biurrun (idoia.biurrun@ehu.es). Please check a current issue of Palaearctic Grasslands for the format and style. Deadline for submission to the next issue is $\mathbf{1 5}$ December 2020

Photo and art contributions (photos for general illustrative purposes with captions; Photo Stories; contributions to Photo and Art Competition) should be submitted to our Photo Editor Rocco Labadessa (rocco.labadessa@gmail.com). Deadline for submissions to the next Photo Competition on "Grassland studies" is 15 December 2020.

Contributions to the section "Recent Publications of our Members" should be sent to Iwona Dembicz (i.dembicz@gmail.com) and those for "Forthcoming Events" to Alla Aleksanyan (alla.alexanyan@gmail.com).

Photos included in submissions have always to be delivered in two forms, embedded in the document and as separate jpg (or tiff) files with sufficient resolution for printing (i.e. not less than $1 \mathrm{MB}$ ).

Palaearctic Grasslands is published by EDGG c/o Prof. Dr. Jürgen Dengler, Plant Ecology, BayCEER, University of Bayreuth, Universitätsstr. 30, 85447 Bayreuth, Germany.

\section{Editorial Board}

CHIEF EDITOR:

Anna Kuzemko, Ukraine

DEPUTY CHIEF EDITORS:

Idoia Biurrun, Spain

Jürgen Dengler, Switzerland

\section{EDITORAL BOARD:}

Alla Aleksanyan, Armenia

Didem Ambarlı, Turkey

Dolores Byrne, Ireland

Iwona Dembicz, Poland

Edy Fantinato, Italy

Magdalena Firganek-Fulcher, UK

Paul Goriup, UK

Riccardo Guarino, Italy

Richard Jefferson, UK

Gwyn Jones, UK
Rocco Labadessa, Italy

Frank Yonghong Li, China

Ashley Lyons, UK

Lorna Marcham, UK

Jim Martin, Ireland

James Moran, Ireland

Jalil Noroozi, Austria

Arkadiusz Nowak, Poland

Salza Palpurina, Bulgaria

Nina Polchaninova, Ukraine

Solvita Rūsiṇa, Latvia

Stuart Smith, UK

Laura Sutcliffe, Germany

Péter Török, Hungary

Atushi Ushimaru, Japan

Orsolya Valkó, Hungary

Stephen Venn, Finland

On front cover page: Stipa capillata in a forb-bunchgrass steppe, Cherkasy region, Ukraine. Photo: D. Shyriaieva. 


\section{Editorial}

Dear readers,

Autumn is the time when harvest festivals are held in many countries; so in our autumn issue we also usually summarize the field season in our own harvest festival. This year has not been easy for many of us. The Covid 19 pandemic is continuing, but we have already learned to coexist with it. That's why many of us still had a very productive field season. You will find proofs of that throughout this issue. First of all, there is a piping hot Scientific Report from the ad hoc 14th EDGG Field Workshop in Switzerland Alps in early September (pp. 14-42). It was organized by Jürgen Dengler after the originally planned 14th Field Workshop earlier this year in Ukraine had been cancelled. The sampling in the alpine environments was extremely productive and will provide a significant addition to our GrassPlot database. Since most of us are still limited in our movements and can only remember the charming grassland sites that we are not able to visit this year, we decided to continue our section "Glimpses of a Grassland", started in the previous issue, and you will find two new "Glimpses" on pages 63-67. There are also three longer charming "Photo Stories" on grasslands in Poland and Russia (pp. 43-62). Perhaps the limited travel opportunities, and perhaps also the usual enthusiasm of our members, has contributed to productive work with research data from previous years, including databases. Therefore, we are pleased to present to you the new extensive "Databases" menu on the EDGG website (pp. 5-9). This tool also contains the prototype of the GrassPlot Diversity Explorer that allows you to find out what the mean, minimum and maximum richness values of grasslands and other open habitats of the Palaearctic are - across taxonomic groups, grain sizes, vegetation types and regions. As we have a lot of work ahead of us to analyze the results of our research, organize collections, write articles, etc., we hope that our autumn issue will not only give you pleasant memories of summer, but also inspire new ideas for your further research and activities. We wish you a pleasant reading! Take care of yourselves and stay with us.

Anna Kuzemko, Chief Editor

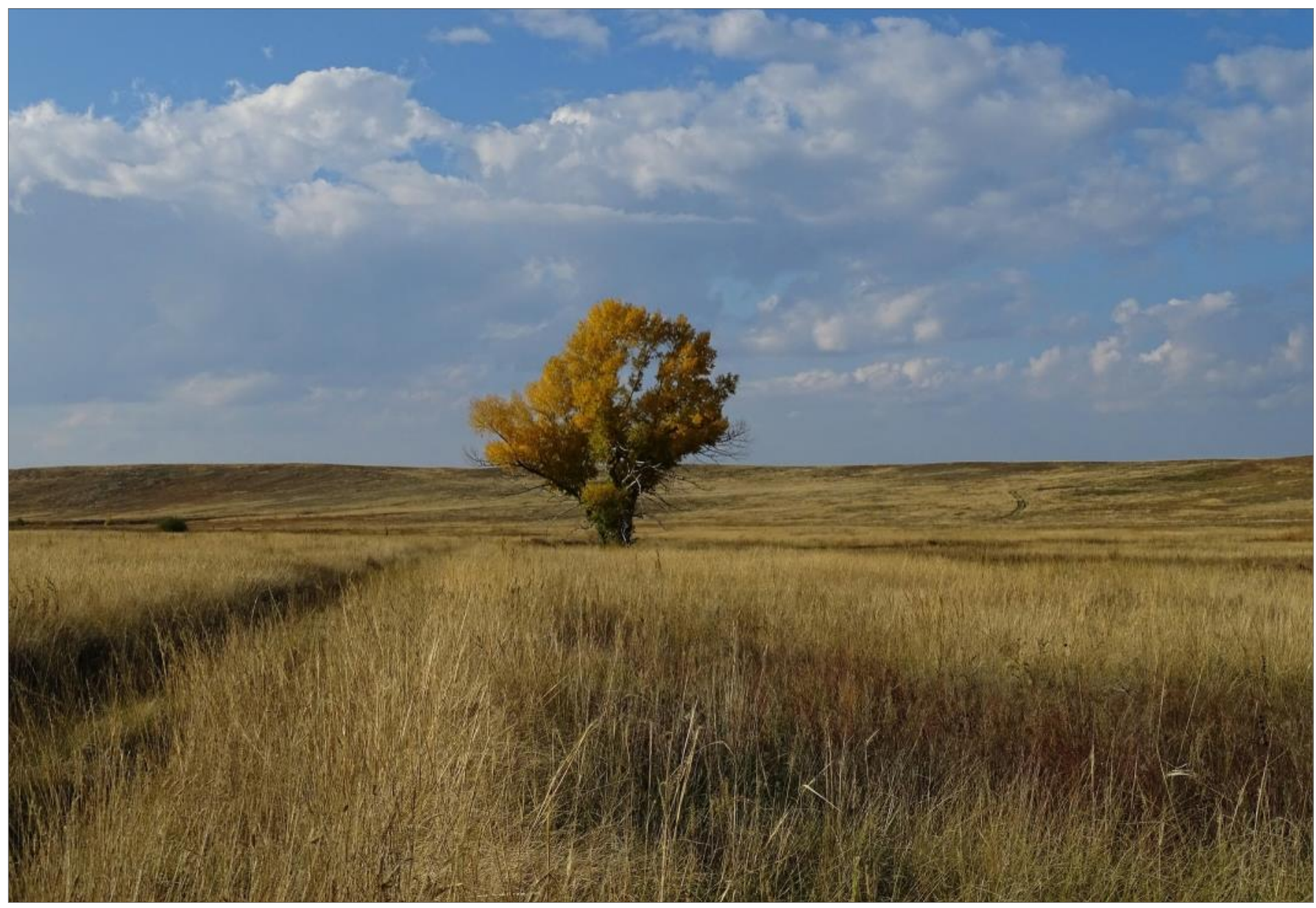

Poplar tree in typical steppe. Orenburg Province, Russia. Photo: I. Smelansky. 


\section{News}

\section{Updates about EDGG events in 2021}

The conference organizing committee is following the global Covid-19 situation regarding next year's Eurasian Grassland Conference. We plan to hold the conference in Tolosa, Spain, but only as long as it can succeed without jeopardizing the health and safety of all participants. We anticipate that the pandemic will decline by the time of the conference, $6-12^{\text {th }}$ September 2021, and we are also hopeful that an effective vaccine will be widely available, permitting relaxation of the currently widespread travel restrictions. If those conditions are not met and we cannot be certain of the safety of participants, then we will consider organizing an alternative online event. The final decision will be made and announced by the end of February 2021.

Due to the uncertain (and rather bad) epidemic situation in many countries in recent weeks, we decided to postpone the decision on the organization of the Field Workshop in Ukraine in 2021 to the start of next year. If the situation is improved then the Field Workshop will be held from 24 May to 2 June 2021. We hope that it will be possible, despite the currently not very optimistic epidemiological predictions. The final decision will be made and announced by the end of February 2021.

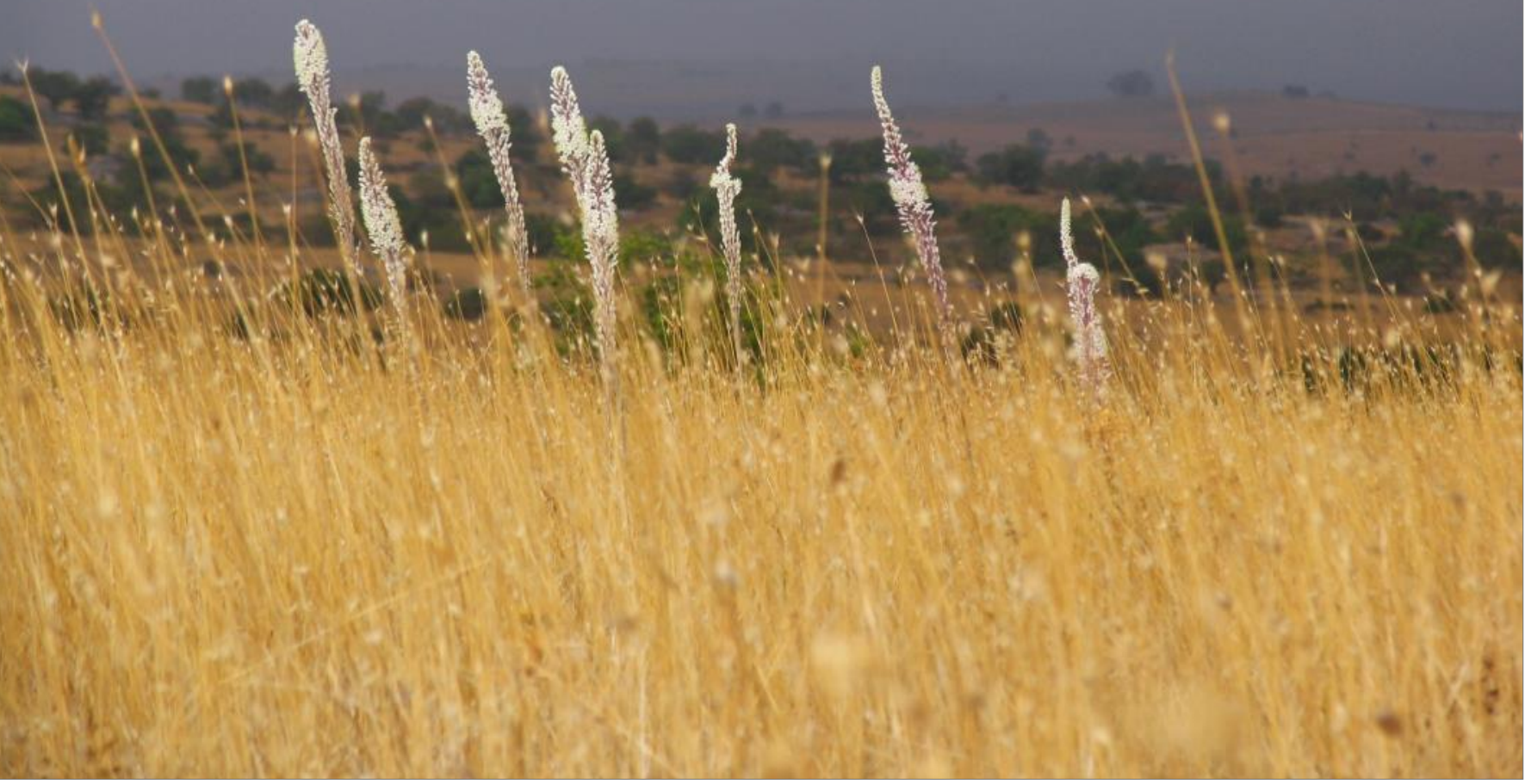

Drimia maritima in a dry grassland before a late-summer storm. Alta Murgia, Puglia, Italy. Photo: R. Labadessa. 


\section{Databases: A new menu item on the EDGG website}

We are pleased to inform you about "Databases", a new extensive feature on the EDGG website. It contains five different pages related to the databases of plot-level vegetation data. With those pages, we aim to provide comprehensive information about vegetation plot databases related to grasslands in the Palaearctic, i.e. GrassPlot and regional grassland databases, in which EDGG has a key role in establishment and maintenance. The core is GrassPlot, the EDGG-associated multi-scale plot-level data, including all those from the EDGG Field Workshops. On a separate page, you can find the GrassPlot Diversity Explorer, an interactive tool developed by Remigiusz Pielech to explore plant diversity data based on the information contained in the 200,000 plots in GrassPlot. We also provide up-to-date information about the ongoing and completed projects using data of GrassPlot. On the last page, you can find publications from GrassPlot and the regional EDGG-associated databases. You are welcome to explore the new pages and functionalities!
The Introduction page (Fig. 1) provides an overview of the content and importance of vegetation plot data and important databases collecting grassland vegetation data at the plot level around the world.

The GrassPlot page (Fig. 2) provides detailed information about the GrassPlot database, an EDGG-affiliated database of multi-scale plant diversity in Palaearctic grasslands. It is a repository for the data collected at the Field Workshops of the EDGG and similar multi-scale sampling schemes. You can find information about the establishment and management of the database, including the custodians and governing board, the content of the database, materials such as Bylaws and Newsletters. Two essential sections are devoted to the GrassPlot projects. In the accordion part of the page, you can click to see information about ongoing and completed projects together with related publications (Fig. 3).

\section{EDGG
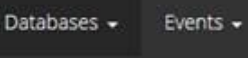 \\ News $\log$ in \\ Introduction \\ Vegetation plot records (relevés) are standardized descriptions of plant community compos these areas, all occurring plant species (vascular plants, but often also bryophytes, lichens and cover or cover-abundance classes of Braun-Blanquet). Additionally, they contain information o individual layers), location, time and in most cases at least some environmental factors measu land use type, soil parameters).}
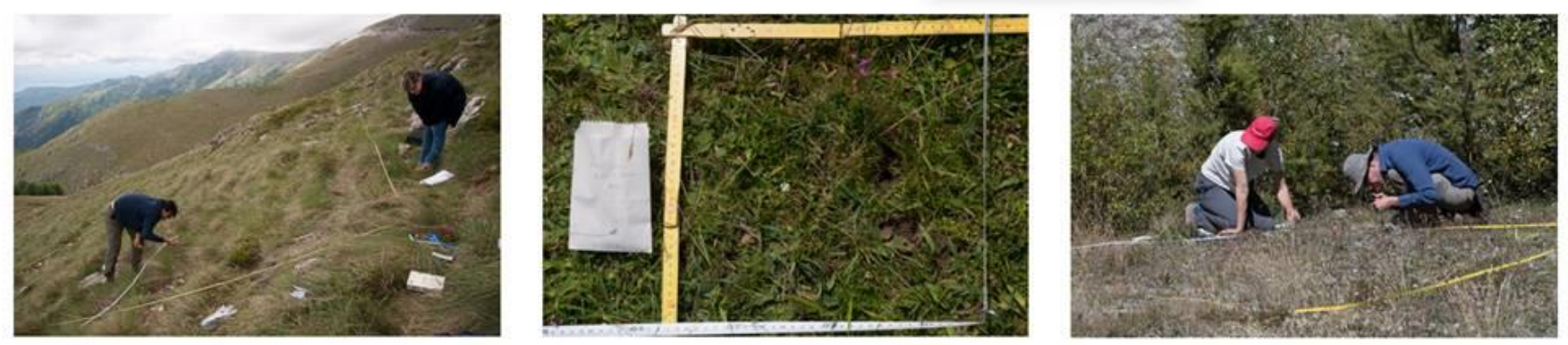

Photos by J. Dengler

Vegetation plot records are used in one way or another in most plant community ecological research. They have been sampled all around the world in a relatively uniform manner since about 100 years. This results in estimated 5-10 million existing relevés in Europe (with its strong phytosociological tradition) and perhaps 10-20 million worldwide. Such vegetation plots have big advantages for macroecological studies of plants and vegetation over more widely used data sources such as the Global Biodiversity Information Facility (GBIF) that provides point distribution data for individual species:

- they provide true community data of species co-occurring in close neighbourhood and sharing the same environmental conditions and competing for the same resources,

- they provide information on dominance and frequency of each species,

- they contain information on true absences (i.e. a species not listed for a plot does not occur there, which is not the case with GBIF data), an important

feature for modelling studies, and

- they typically contain at least some structural and environmental parameters determined locally (while GBIF studies have to rely exclusively on modelled environmental parameters at much coarser scale) 


eDGG Home About us EDGG Conferences - Field Workshops - Publications - Databases - Events - News Log in

\section{GrassPlot}

GrassPlot is the EDGG-affiliated database of multi-scale plant diversity in Palaearctic grasslands. The database started as a repository for the data collected at the Research Expeditions/Field Workshops of the Eurasian Dry Grassland Group (EDGG) and similar multi-scale sampling schemes. It formerly was named "Database Species-Area Relationships in Palaearctic Grasslands". GrassPlot is registered under the code EU-00-003 in the Global Index of Vegetation-Plot Databases (GIVD; www.givd.info).
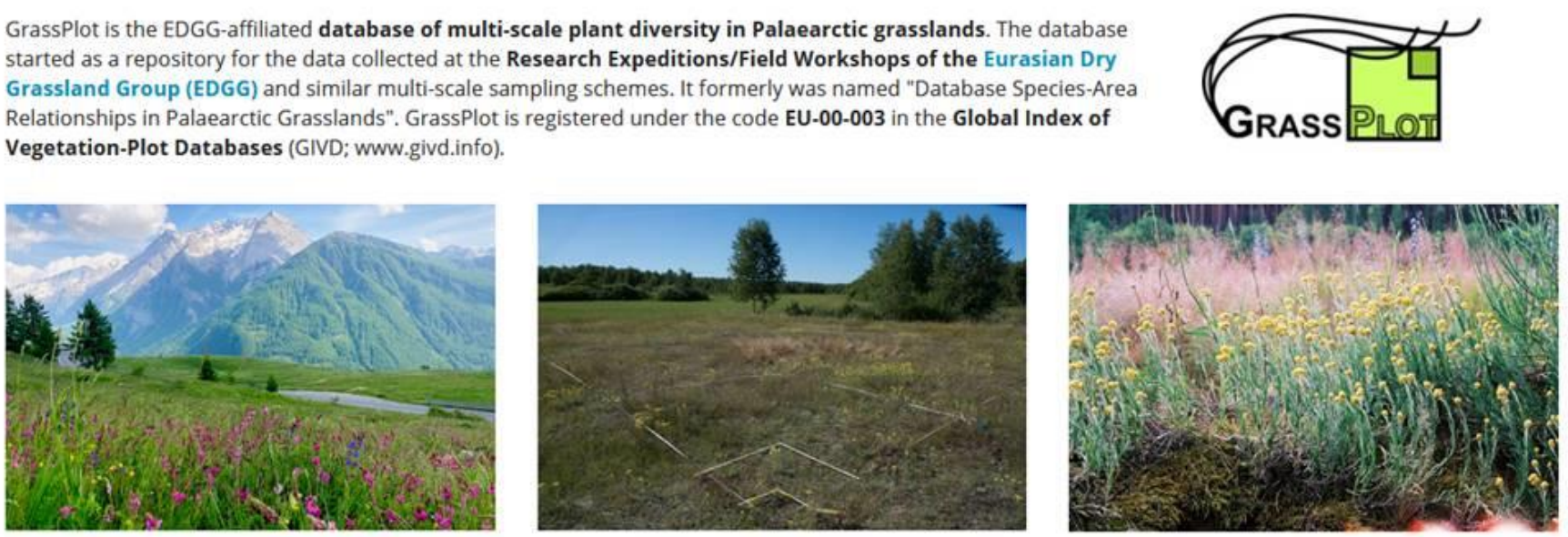

Photos by F, Napoleone (left), J. Dengler (middle), R. Pielech (right)

GrassPlot is looking for high-quality phytodiversity data sampled on plots of the following standard areas: $0.0001 \mathrm{~m}^{2}, 0.001$ or $0.0009 \mathrm{~m}^{2}, 0.01 \mathrm{~m}^{2}, 0.1$ or $0.09 \mathrm{~m}^{2}, 1 \mathrm{~m}^{2}, 10$ or $9 \mathrm{~m}^{2}, 100 \mathrm{~m}^{2}$, and 1000 or 900 or $1024 \mathrm{~m}^{2}$.

We preferentially include nested-plot multi-scale data, but we also welcome data for single grain sizes, provided they were carefully sampled with the aim of complete species lists. We request that plots have been precisely delimited in the field, usually with metal pins in the corners and a measuring tape on the

Fig. 2. The GrassPlot page devoted to the GrassPlot database.

Content of the Grassplot Database

Governing Board

Ongoing projects

Completed projects

\section{Opt-out papers \#01A, \#01B: "Database papers"}

Start: March 2017

Project leader(s): Jürgen Dengler (CH) \& Idoia Biurrun (ES)

Summary: The GrassPlot Consortium published an initial paper that the describes the scope and the content of the database in 2018. When there are major updates, we are publishing follow-ups of this database paper.

\section{Publications:}

Dengler, J., Wagner, V., Dembicz, I., Garcia-Mijangos, I., Naqinezhad, A., Boch, S., Chiarucci, A., Conradi, T., Filibeck, G., (...) \& Biurrun, I. 2018. GrassPlot - a database of multi-scale plant diversitv in Palaearctic

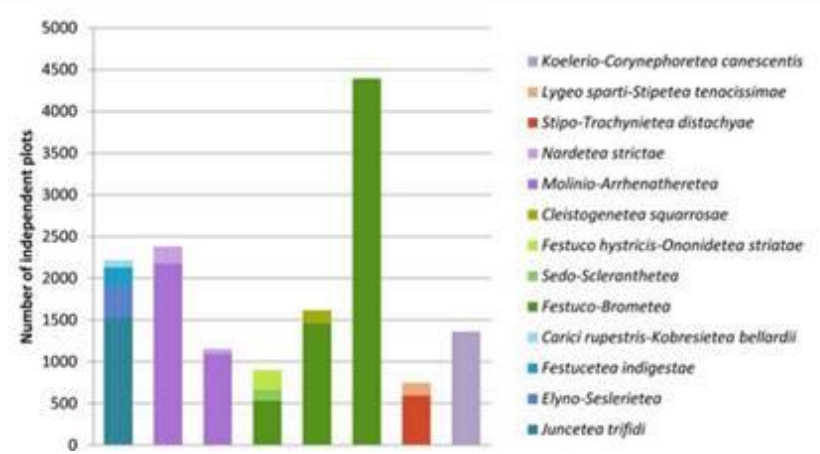

Fig. 3. The accordion section of the GrassPlot page includes six sections: Content of the GrassPlot Database, Governing Board, Ongoing Projects, Completed Projects, Initial Grassplot Workshop, and Materials. After clicking the headings, you can see detailed information related to that subject. 


\section{GrassPlot Diversity Explorer}

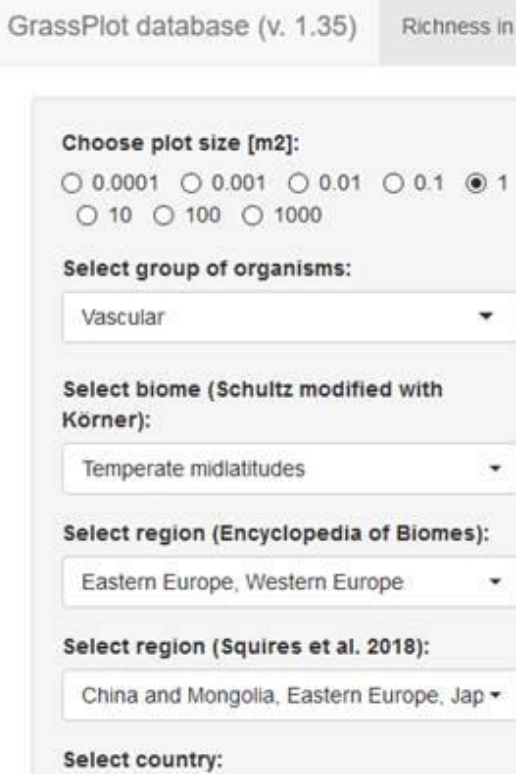

Fig. 4. GrassPlot Diversity Explorer presenting vascular plant species richness for different vegetation types. Note that the dataset used to display the plot is filtered to $1 \mathrm{~m}^{2}$ plots located in temperate mid-latitudes of Eastern and Western Europe.

GrassPlot Diversity Explorer was created to enable flexible exploration of data gathered in the GrassPlot database. The GrassPlot Diversity Explorer was developed as a web application using the Shiny package (Winston et al. 2020) in $R$ software, and is embedded within the EDGG webpage. In its current form, it has four different tabs containing a variety of information. The first tab, 'Richness in vegetation types,' shows boxplots with species richness of selected groups (vascular plants, bryophytes, lichens, or their combinations) within different vegetation types that were distinguished in the GrassPlot database (Fig. 4). One can also filter the dataset used by selecting among plot size grains, biomes and countries.

The second tab, 'Richness in biomes and regions,' allows generating similar plots for species richness in different geographical regions. One can filter data based on plot size, group of organisms and vegetation type. The third tab, 'Descriptive statistics,' provides basic statistics of species richness, including mean, maximum, minimum and a measure of variation (standard deviation) within the selected subset (Fig. 5). One can filter data based on plot size, vegetation type or locality within biome or country.

Finally, the last tab presents a map with the distribution of the plots and also gives the option to subset the displayed dataset based on several filters. It was prepared using the leaflet package (Cheng et al. 2019) in R. For example, Figure 6 illustrates the distribution of the plots from dune and sandy grasslands in Europe and Central Asia.
The current version of the GrassPlot Diversity Explorer uses 118,912 plots (dataset v. 1.35) and will be updated continuously. Future development is also planned, including code optimization and adding new filters, for example, selection based on syntaxonomy (i.e., classes, orders or alliances).

The Regional Databases page (Fig. 7) is devoted to the regional grassland or general non-forest databases that are managed by several EDGG members. You can find detailed information about foundation, content, spatial coverage and consortia of the Balkan Dry Grassland Database (BDGD), the German Grassland Vegetation Database (GrassVeg.DE), the Nordic-Baltic Grassland Vegetation Database (NBGVD), the Romanian Grassland Database (RGD), and the Ukrainian Grassland Database (UGD). More are on the way.

An increasing number of publications use data from one or several of these databases. You can find detailed information about these in the Publications using our data page (Fig. 8) under three headings: publications from GrassPlot, from EVA and sPlot.

The overall Database section of the EDGG website will be updated and managed by Jutta Kapfer (jutta.kapfer@nibio.no), and the GrassPlot Diversity Explorer will be maintained by Remigiusz Pielech (remekpielech@gmail.com). Please get in contact with them if you have suggestions or comments. 


\section{GrassPlot Diversity Explorer}

GrassPlot database (v. 1.35) Richness in vegetation types Richness in biomes and regions Descriptive statistics Map

Choose plot size [m2]:
$0.000100 .00100 .01 \quad 0.1$
Select group of organisms:
Bryophytes
Select vegetation type:
Alpine grassland
Select biome (Schultz modified with
Korner):

Descriptive Statistics

value

N. 500

\begin{tabular}{|l|l|l|l|l|l|l|r|r|}
\hline & Min & Q1 & Mean & Median & Q3 & Max & Std.Dev & I \\
\hline value & 0.00 & 2.00 & 4.91 & 3.00 & 7.00 & 15.00 & 4.43 \\
\hline
\end{tabular}

Generated by summarytools 0.9 .3 ( $R$ version 3.6 .1 ) 2020-10-12

Fig. 5. GrassPlot Diversity Explorer presenting bryophyte species richness in $10 \mathrm{~m}^{2}$ plots in alpine grasslands.

eDGG Home Aboutus EDGGConferences - FildWorkshops - Publications - Databases - Events - News Log in

\section{GrassPlot Diversity Explorer}

GrassPlot database (v. 1.35) Richness in vegetation types Richness in biomes and regions Descriptive statistics Map

Select vegetation type:
Dune, Sandy dry grassland
Select biome (Schultz modified with
Korner):
Alpine, Boreal zone, Dry midlatitudes, Di-
Select region (Encyclopedia of Biomes):
China, Eastern Europe, Japan and Kores -
Select region (Squires et al. 2018):
China and Mongolia, Eastern Europe, Ja -
Select country:
AD, AM, AT, AZ, BA, BE, BG, BY, CH, C.

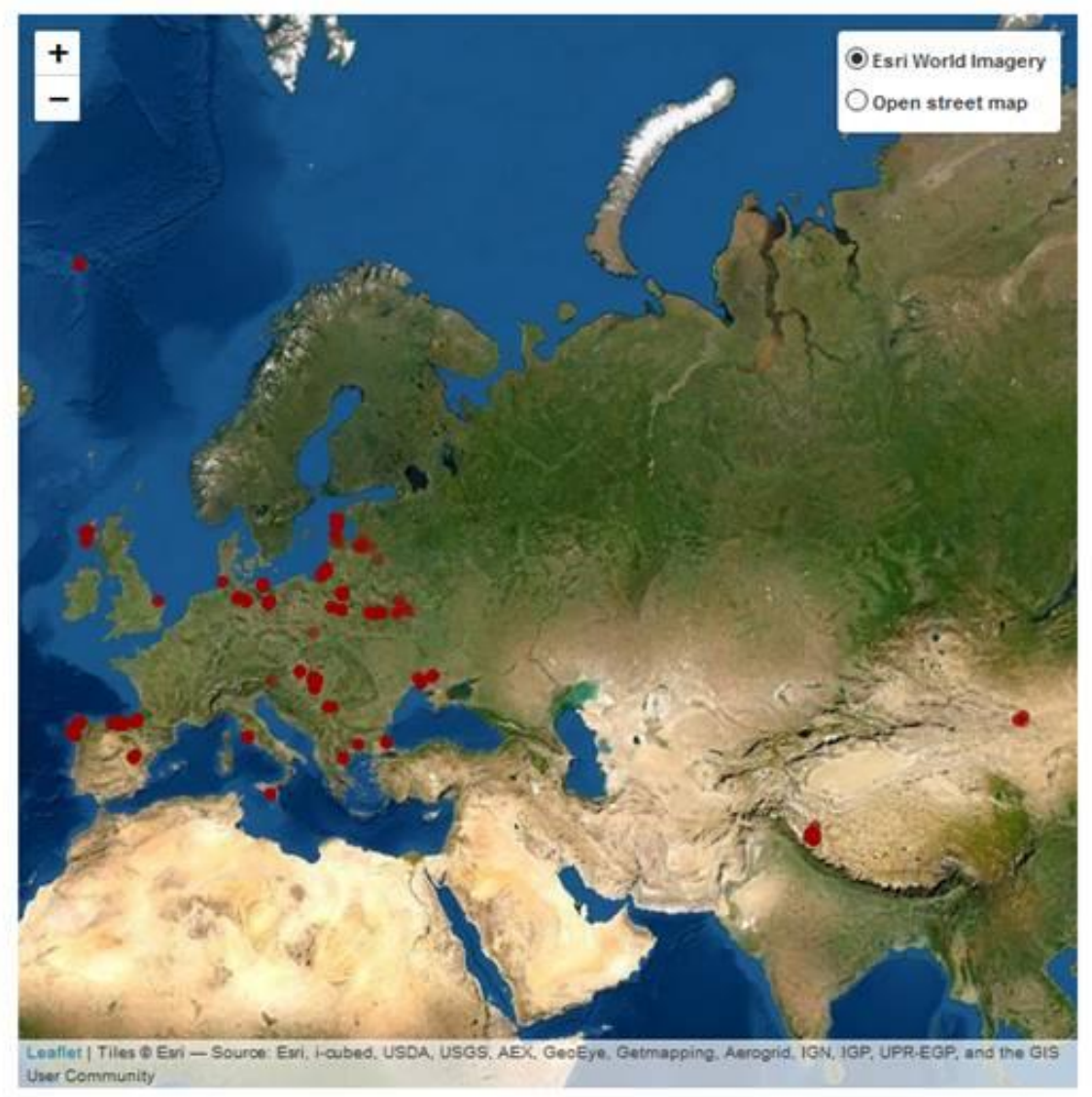




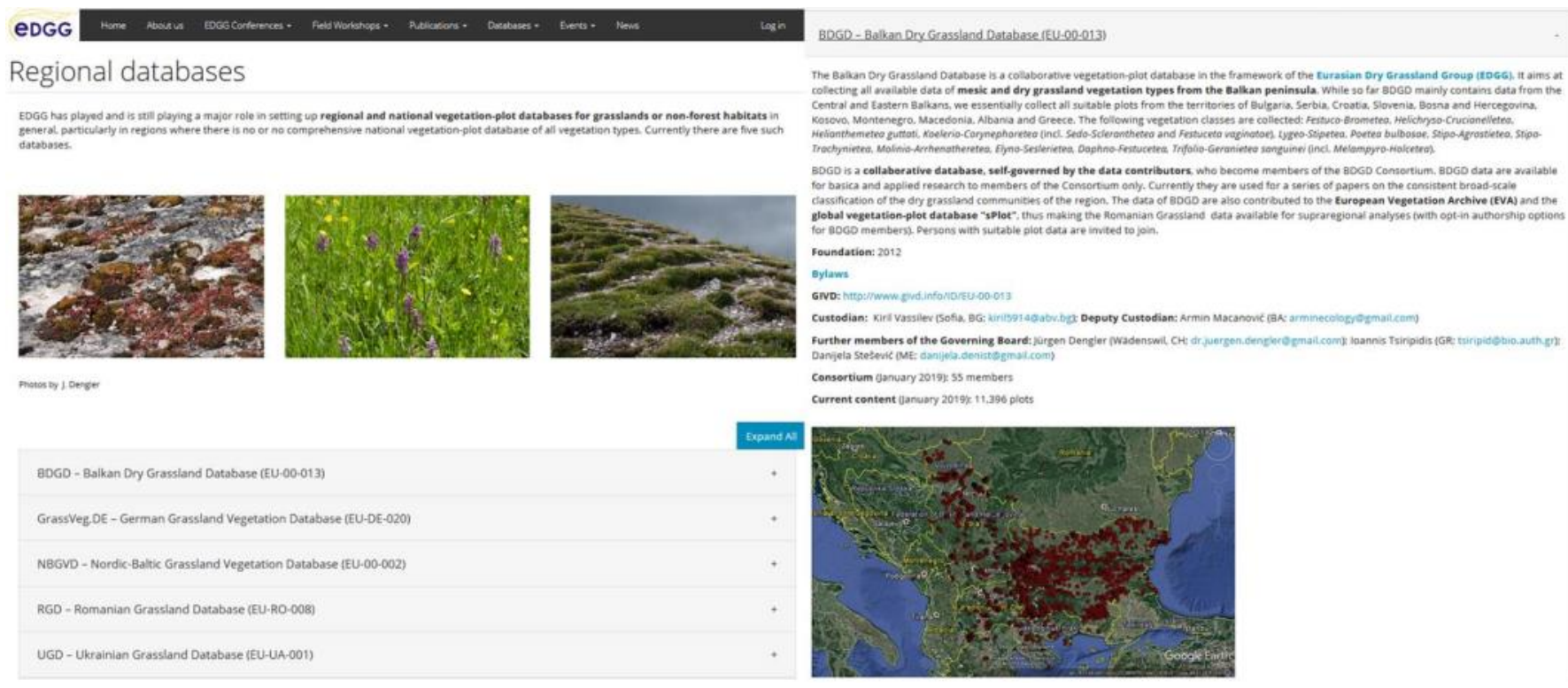

Fig. 7. The Regional Databases page (left) and the content of Balkan Dry Grassland Database section (right) as an example.

eDGG

Publications using our data

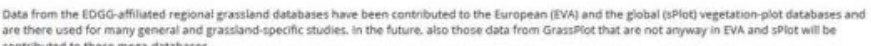
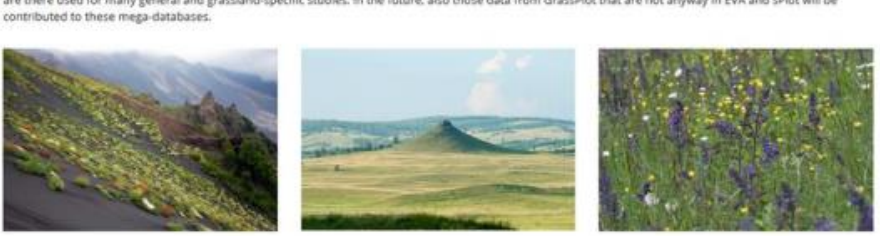

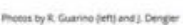

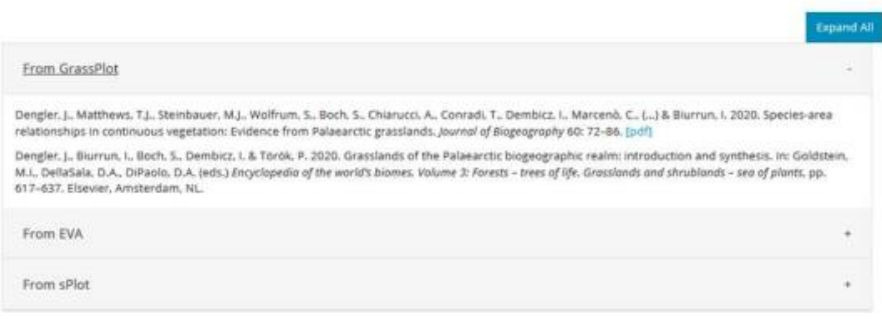

Fig. 8. Publications using our data of the Databases menu.

\section{References}

Cheng, J., Karambelkar, B. \& Xie, Y. 2019. leaflet: Create Interactive Web Maps with the JavaScript 'Leaflet' Library. R package version 2.0.3. https://CRAN.R-project.org/package=leaflet

Winston, C., Joe, C., Allaire, J.J., Xie, Y. \& McPherson, J. 2020. shiny: Web Application Framework for R. R package version 1.5.0. https://CRAN.R-project.org/package=shiny

Alla Aleksanyan, Yerevan, Armenia, alla.alexanyan@gmail.com

Didem Ambarl, Freising, Germany didem.ambarli@gmail.com

Jürgen Dengler, Wädenswil, Switzerland, dr.juergen.dengler@gmail.com Jutta Kapfer, Tromsø, Norway, jutta.kapfer@nibio.no

Remigiusz Pielech, Kraków, Poland, remekpielech@gmail.com 


\section{Call for the new Photo Competition "Grassland studies" and Photo Story}

The theme of the current Photo Competition is "Grassland studies", dedicated to all the field activities carried out for sampling and studying the various components of grassland ecosystems.

You are invited to send up to three high-quality photographs within the competition theme (full size JPEG or TIFF images, at least $300 \mathrm{dpi}$ ) together with captions giving a short title or description (a short text to explain the meaning or a story beyond the shot) and information on the subject (species name, date, place name).

The selection will be made by a jury of at least five members from the Editorial Board of the journal, assuming that a minimum of 3 contributors and/or 6 contributions is needed to select a winner.

The three best shots will be awarded with full space in the next issue, but we reserve the right to use further submitted materials for illustrative purposes in other parts of the issue.

If you feel you can contribute with your shots, don't be shy! Everyone can join the competition!

Contributions for the Photo Story section are always welcome. Photo Story is an open space where members can submit their own photo collection on a certain grasslandrelated topic of their choice. High-quality photos should be provided together with their captions (at least species names or landscape description), a brief text and possibly other graphical elements (like a map or a drawing). The selection of photos should fit for 3-8 pages and the proponents should already propose a preliminary layout (in PDF or MS Word format), which will be finally typeset by Editors. As an example, you may take a look at the Photo Stories published in this issue.

As with Scientific Papers, Photo Stories undergo a review process with a focus on photo quality. There is no guarantee that they are accepted without changes, and late submissions might be published in subsequent issue.

If you want to contribute to these sections, or if you simply want to help us enriching the aspect of the journal, please submit your photos together with required information to Rocco (rocco.labadessa@gmail.com).

Deadline for photo submissions is 15 December 2020!

Rocco Labadessa, Bari, Italy rocco.labadessa@gmail.com

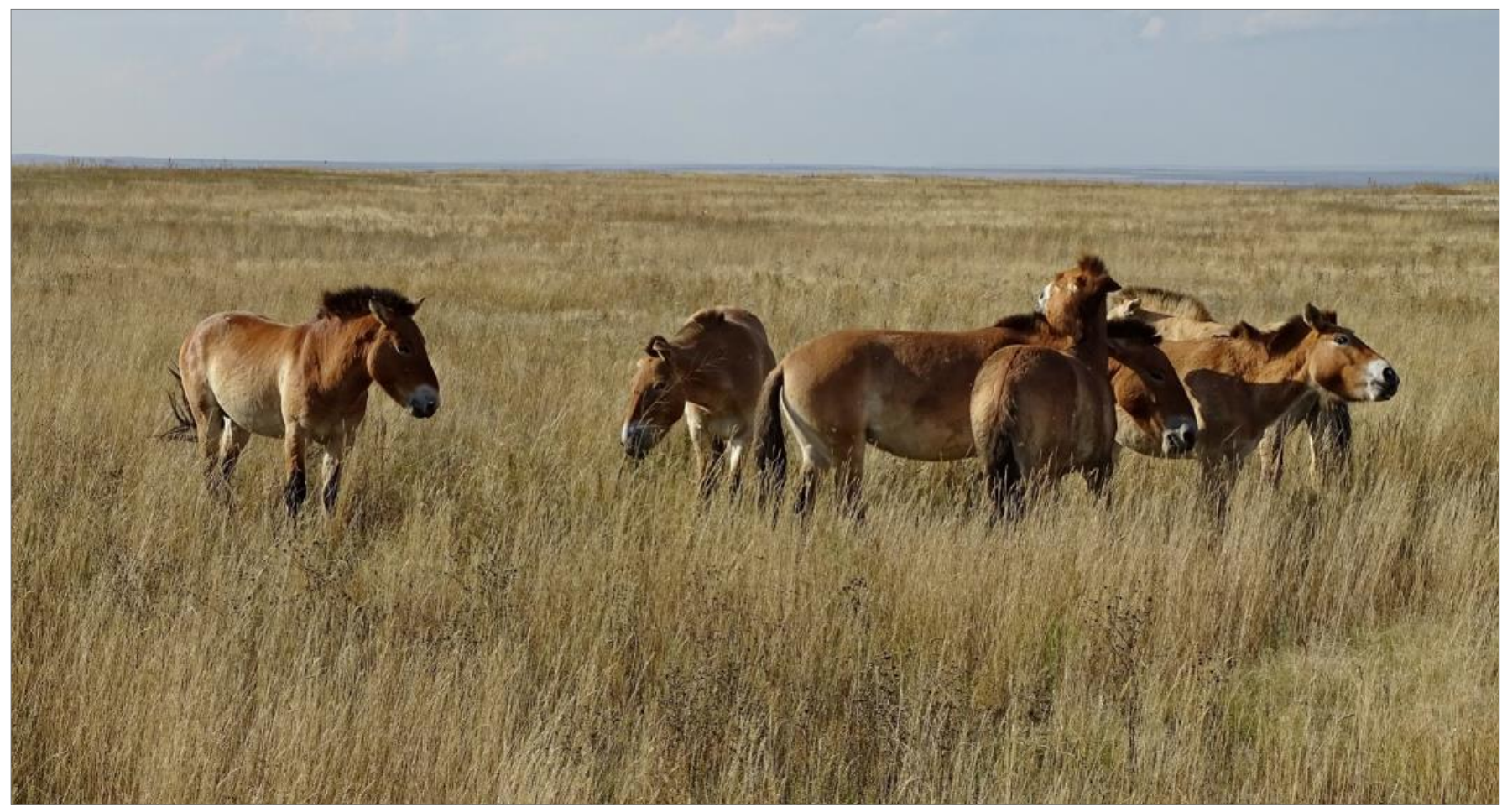

Pzewalski horses (Equus ferus przewalskii) in typical steppe in the Orenburg SNR, Russia. Photo: I. Smelansky. 


\section{EDGG Publication}

\section{Ecology and Evolution of Steppe Biodiversity: A new EDGG Special Issue in the journal Flora}

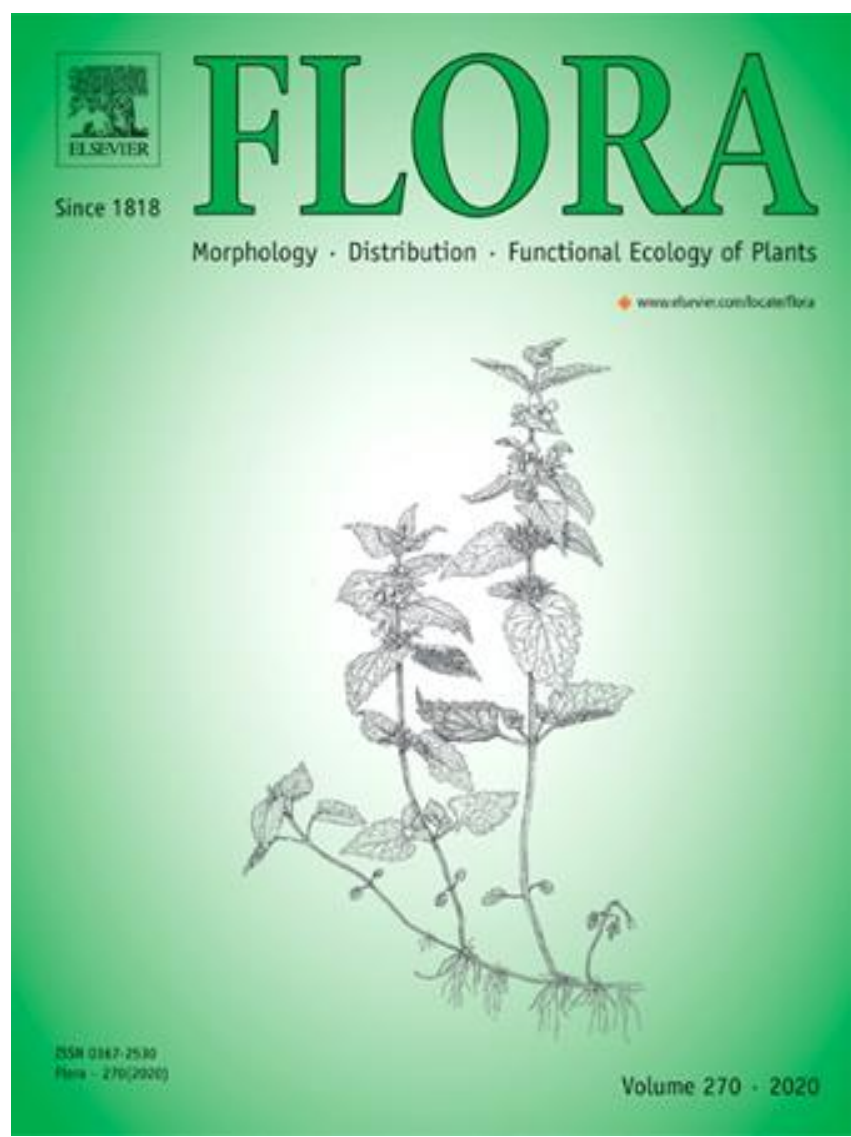

In the summer of 2018, a special issue on the ecology and evolution of steppe biodiversity was initiated by the Editorial Board of Flora with the collaboration of EDGG. The special issue was finalised in the summer of 2020 and contains 12 papers with 75 authors from 13 countries. The special issue was edited by handling editors Péter Török (Hungary), Barbara Neuffer (Germany), Karl-Georg Bernhardt (Austria), and Karsten Wesche (Germany). Both basic research and applied studies were invited, and the present papers addressed (i) steppe biodiversity and phylogeography, and (ii) land use effects and grazing. All shared an overarching interest in understanding steppe biodiversity, with the former dealing with long, evolutionary timescales and the latter with a focus on current processes. For both, interactions with climate are key topics. Climate history but also current climate conditions differ between regions within the vast Eurasian steppe belt. How this has affected phylogeography of a given steppe region, and how local climate interacts with modified local land use impact, still is to be explored.

The papers in the special issue indicated that the steppes are characterised by high levels of plant diversity which sup- port complex and mosaic patterns of biodiversity richness and habitat richness at multiple scales. These complex patterns have originated and are sustained by the interaction of macroclimate and local patterns of abiotic factors, and are sustained at the local scale by small-scale disturbances. The authors conclude that the macroclimate and landscape history of the Eurasian steppe belt affect species phylogenies, genetic subdivisions across species ranges and fine-scale distribution patterns. Thus, molecular signals and plant community composition may mirror biogeographic dynamics and colonization of steppe habitats from different source areas.

Current biodiversity patterns are strongly shaped by increased levels of human influence. Drastic area loss and fragmentation of steppes and subsequent land-use changes mostly in the form of overgrazing, transformation to arable land or other forms of overuse threaten not only steppe biodiversity at the species level, but also negatively affect the functional and phylogenetic diversity of steppe plant communities. They also decrease their stability and, thus, their resistance and resilience to climatic extremities predicted by models of climate change. It was stressed that the different types of steppe habitats even at the small scale need locally adapted and fine-tuned management, mostly in form of livestock grazing and/or mowing. Temperate grasslands are among the least protected habitats worldwide. The area loss and fragmentation of steppe biodiversity are especially alarming taking also into consideration that only a very small proportion of steppes is under formal protection in e.g. reserves.

\section{The papers in the special issue}

Török, P., Neuffer, B., Heilmeier, H., Karl-Georg, B. \& Wesche, K. 2020. Climate, landscape history and management drive Eurasian steppe biodiversity. Flora 271: 151685. Editorial. DOI: 10.1016/j.flora.2020.151685

Žerdoner Čalasan, A., Seregin, A.P., Hurka, H., Hofford, N.P. \& Neuffer, B. 2020. The Eurasian steppe belt in time and space: Phylogeny and historical biogeography of the false flax (Camelina Crantz, Camelineae, Brassicaceae). Flora 260: 151477. DOI: 10.1016/j.flora.2019.151477

Friesen, N., Smirnov, S.V., Shmakov, A.I., Herden, T., Oyuntsetseg, B. \& Hurka, H. 2020. Allium species of section Rhizomatosa, early members of the Central Asian steppe vegetation. Flora 263: 151536. DOI: 10.1016/ j.flora.2019.151536 
Friesen, N., Zerdoner Calasan, A., Neuffer, B., German, D.A., Markov, M. \& Hurka, H. 2020. Evolutionary history of the Eurasian steppe plant Schivereckia podolica (Brassicaceae) and its close relatives. Flora 268: 151602. DOI: 10.1016/i.flora.2020.151602

Seidl, A., Pérez-Collazos, E., Tremetsberger, K., Carine, M., Catalán, P. \& Bernhardt, K.-G. 2020. Phylogeny and biogeography of the Pleistocene Holarctic steppe and semidesert goosefoot plant Krascheninnikovia ceratoides. Flora 262: 151504. DOI: 10.1016/i.flora.2019.151504

Kropf, M., Bardy, K., Höhn, M. \& Plenk, K. 2020. Phylogeographical structure and genetic diversity of Adonis vernalis L. (Ranunculaceae) across and beyond the Pannonian region. Flora 262: 151497. DOI: 10.1016/ j.flora.2019.151497

Plenk, K., Willner, W., Demina, O. N., Höhn, M., Kuzemko, A., Vassilev, K. \& Kropf M. 2020. Phylogeographic evidence for long-term persistence of the Eurasian steppe plant Astragalus onobrychis in the Pannonian region (eastern Central Europe). Flora 264: 151555. DOI: 10.1016/i.flora.2020.151555

Treiber, J., von Wehrden, H., Zimmermann, H., Welk, E., Jäger, E.J., Ronnenberg, K. \& Wesche, K. 2020. Linking large-scale and small-scale distribution patterns of steppe plant species-An example using fourth-corner analysis. Flora 263: 151553. DOI: 10.1016/ j.flora.2020.151553

Oyundelger, K., Ritz, C.M., Munkhzul, O., Lang, B., Ahlborn, J., Oyuntsetseg, B., Römermann, C. \& Wesche, K. 2020. Climate and land use affect genetic structure of Stipa glareosa P. A. Smirn. in Mongolia. Flora 266: 151572. DOI: 10.1016/i.flora.2020.151572

Qin, J., Ren, H., Han, G., Zhang, J., Browning, D., Willms, W. \& Yang, D. 2020. Grazing reduces the temporal stability of temperate grasslands in northern China. Flora 259: 151450. DOI: $10.1016 /$ j.flora.2019.151450

Yang, J.-X., Hou, D.-J., Qiao, X.-G., Geng, X.-M., Guo, K. \& He, W.-M. 2020. Plowing, seeding, and fertilizing differentially influence species diversity, functional groups and community productivity in a degraded steppe. Flora 257: 151414. DOI: 10.1016/j.flora.2019.05.013

Boch, S., Bedolla, A., Ecker, K.T., Ginzler, C., Graf, U., Küchler, H., Küchler, M., Nobis, M.P., Holderegger, R. \& Bergamini, A. 2019. Threatened and specialist species suffer from increased wood cover and productivity in Swiss steppes. Flora 258: 15144. DOI: 10.1016/ j.flora.2019.151444

Kertész, M., G. Ónodi, G., Botta-Dukát, Z., Lhotsky, B., Barabás, S., Bölöni, J., Csecserits, A., Molnár, C., Nagy, J., (...) \& Rédei, T. 2020. Different impacts of moderate human land use on the plant biodiversity of the characteristic Pannonian habitat complexes. Flora 267: 151591. DOI: 10.1016/i.flora.2020.151591

Péter Török, Debrecen, Hungary molinia@gmail.com

Barbara Neuffer, Osnabrück, Germany Hermann Heilmeier, Freiberg, Germany

Karl-Georg Bernhardt, Vienna, Austria Karsten Wesche, Görlitz, Germany

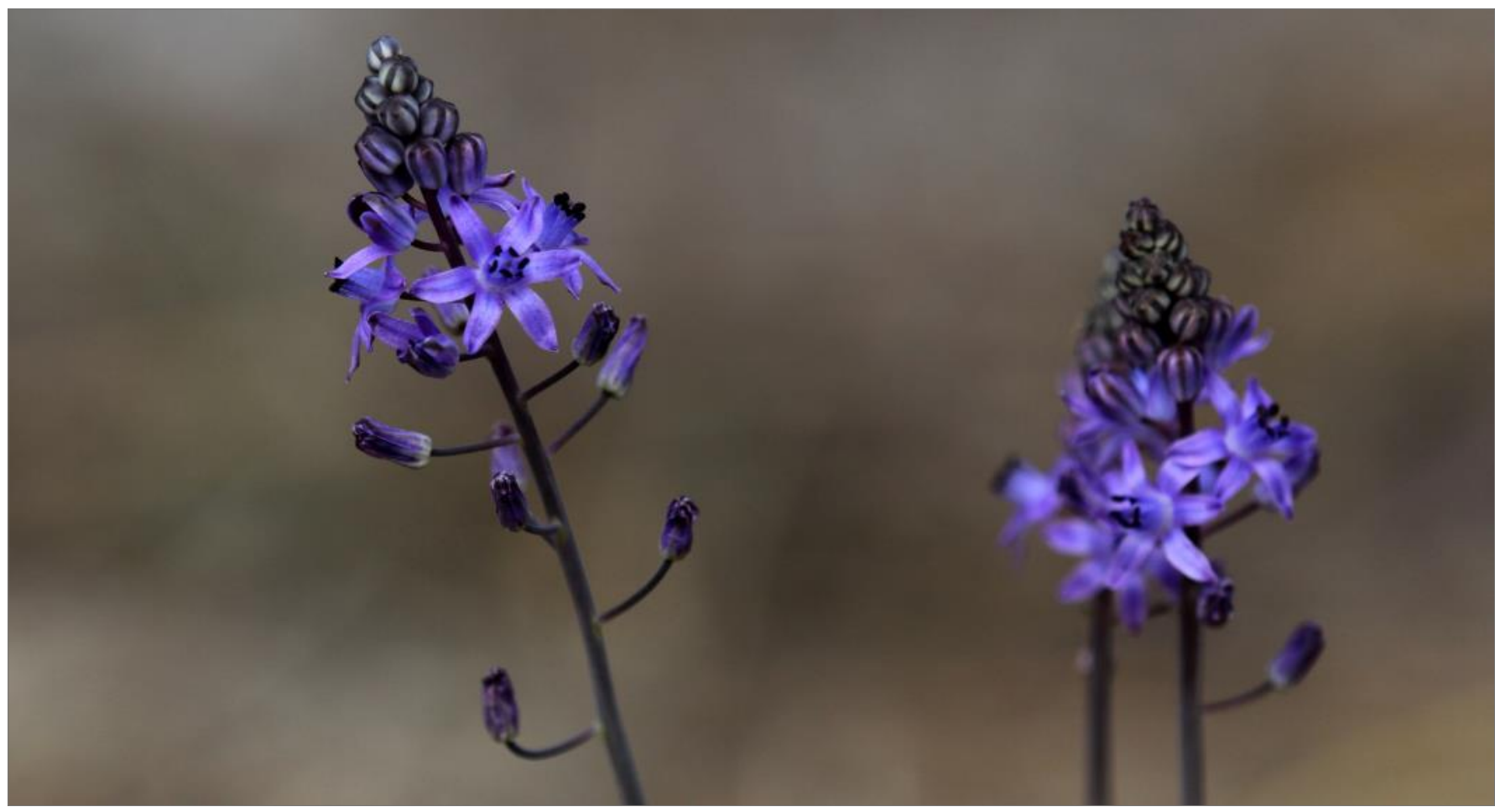

Prospero autumnale. Prespes, NW Greece. Photo: P. Chmielewski. 


\section{Call for the 16th EDGG-edited Grassland Special Fea- ture in Tuexenia: Central European dry grasslands in a changing world}

In 2021, the Eurasian Dry Grassland Group (EDGG; www.edgg.org) continues a long tradition of grasslandrelated publications and will organize the 16th Grassland Special Feature in Tuexenia (www.tuexenia.de).

Tuexenia is a diamond open access, peer-reviewed journal publishing original articles, reviews, and reports. The annual Grassland Special Feature is open to grassland-related topics with a focus on geobotany, vegetation ecology and related sciences such as population biology, biodiversity research, biocenology, restoration ecology, and their applications, particularly in grassland conservation. We further welcome studies involving interactions of plants with other taxa such as animals and fungi, and particularly welcome contributions that were presented on the Eurasian Grassland Conferences or show results from the EDGG Field Workshops. The geographic scope of the Special Feature is Central Europe, comprising Germany, Switzerland, Liechtenstein, Austria, Slovenia, Hungary, Slovakia, Czech Republic and Poland. Contributions from adjacent regions are also welcome if they make a clear connection to Central Europe, at least in the discussion part.
If you plan to contribute, you are invited to send an abstract to the Chair of Guest Editors, Steffen Boch, prior to manuscript submission. Based on these abstracts, we will decide which papers to invite.

Manuscripts should be submitted as soon as possible and preferentially until 15 March 2021. Early submitted manuscripts have a higher chance of inclusion in the next Special Feature 2021. Later submission is only possible after prior consultation with Steffen Boch.

Benefits of submitting to our Special Feature in Tuexenia include:

- Open access and peer reviewed ISI journal (IF 1.05)

- No color and page charges

- Competent Guest Editor Team: Steffen Boch (chair, Switzerland), Thomas Becker (Germany), Balázs Deák (Hungary), Jürgen Dengler (Switzerland), Valentin Klaus (Switzerland).

Steffen Boch, Birmensdorf, Switzerland, also on behalf of the Guest Editor Team steffen.boch@wsl.ch

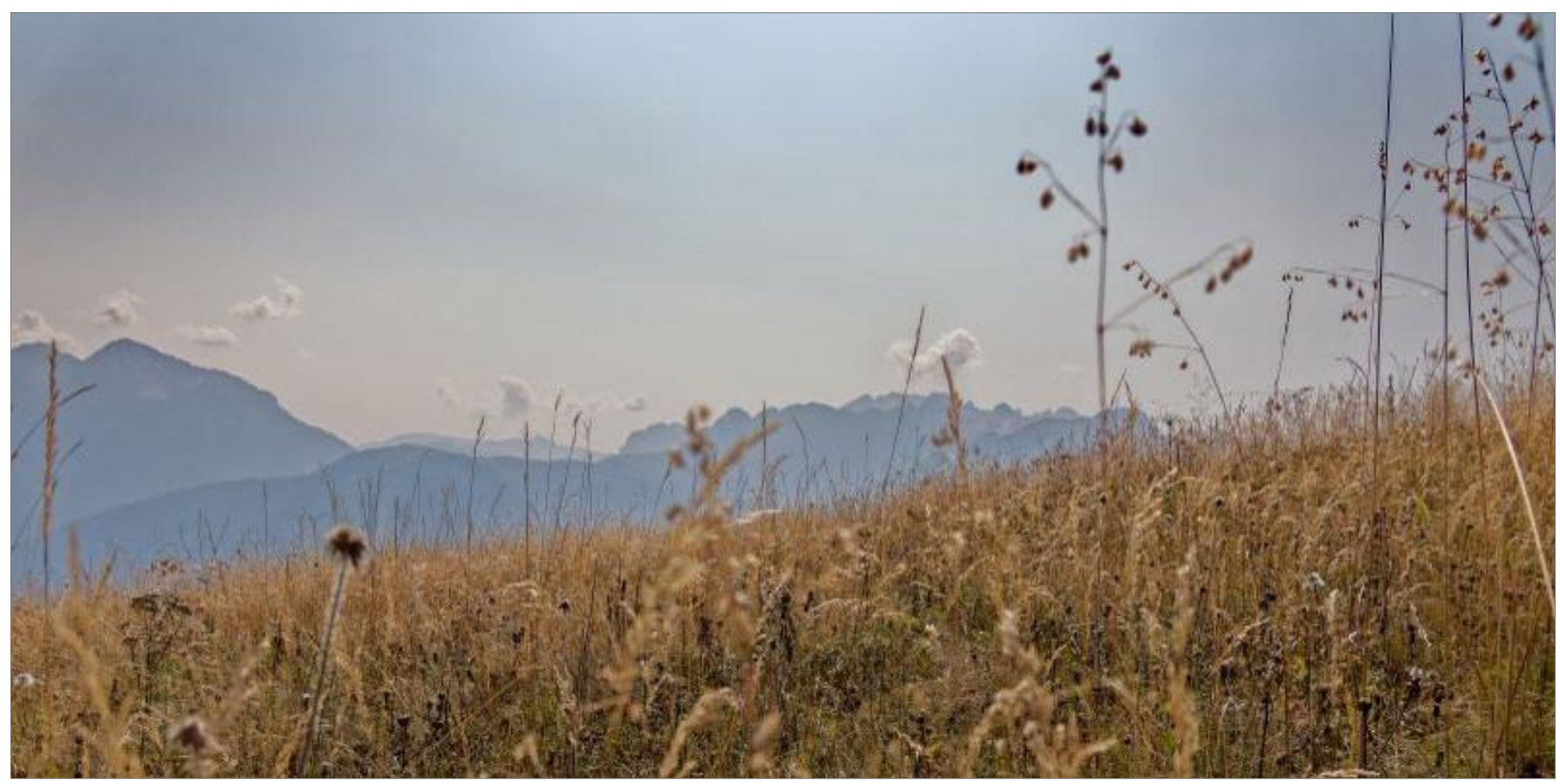

Unmown pasture in Mussen, southeast Carinthia, Gailtaler Alpen, Austria. Photo: M. Magnes. 


\title{
Sampling multi-scale and multi-taxon plant diversity data in the subalpine and alpine habitats of Switzer- land: Report on the 14th EDGG Field Workshop
}

\author{
Jürgen Dengler ${ }^{1,2,3^{*}\left(\frac{1}{0}\right.}$, Beata Cykowska-Marzencka ${ }^{4,5}{ }^{\circledR}$, Timon Bruderer $^{1}$, Christian Dolnik ${ }^{6}$ \\ Patrick Neumann $^{7}{ }^{\circledR}$, Susanne Riedel ${ }^{8}$, Hallie Seiler ${ }^{1}$, Jinghui Zhang ${ }^{1,9}{ }^{\circledR}$ \& Iwona Dembicz ${ }^{10}$
}

\begin{abstract}
${ }^{1}$ Vegetation Ecology, Institute of Natural Resource Sciences (IUNR), Zurich University of Applied Sciences (ZHAW), Grüentalstr. 14, 8820 Wädenswil, Switzerland; dr.juergen.dengler@gmail.com, brudetim@students.zhaw.ch, hallie.seiler@gmx.ch, jhzhang1001@126.com

${ }^{2}$ Plant Ecology, Bayreuth Center of Ecology and Environmental Research (BayCEER), Universitätsstr. 30, 95447 Bayreuth, Germany

${ }^{3}$ German Centre for Integrative Biodiversity Research (iDiv) Halle-JenaLeipzig, Deutscher Platz 5e, 04103 Leipzig, Germany

${ }^{4}$ Department of Mycology, W. Szafer Institute of Botany, Polish Academy of Sciences, Lubicz 46, 31-512 Kraków, Poland; $\underline{\text { b.cykowska@botany.pl }}$

${ }^{5}$ Tiefenhofstrasse 68, 8820 Wädenswil, Switzerland

${ }^{6}$ Department of Landscape Ecology, Institute for Natural Resource Conservation, Kiel University, Ohlshausenstr. 40, 24098 Kiel, Germany; cdolnik@ecology.uni-kiel.de
\end{abstract}

7Erna-Zöller-Str. 13, 24582 Bordesholm, Germany; p.neumann@ecologysh.de

${ }^{8}$ Research Group Agricultural Landscape and Biodiversity, Agroscope, Reckenholzstr. 191, 8046 Zurich, Switzerland; susanne.riedel@agroscope.admin.ch

${ }^{9}$ Ministry of Education Key Laboratory of Ecology and Resource Use of the Mongolian Plateau \& Inner Mongolia Key Laboratory of Grassland Ecology, School of Ecology and Environment, Inner Mongolia University, 010021 Hohhot, China

${ }^{10}$ Department of Plant Ecology and Environmental Conservation, Faculty of Biology, University of Warsaw, ul. Żwirki i Wigury 101, 02-089, Warsaw, Poland, i.dembicz@gmail.com

*) corresponding author

\section{Palaearctic Grasslands 47 (2020): 14-42}

Abstract: The $14^{\text {th }}$ EDGG Field Workshop took place from the $4^{\text {th }}$ to the $14^{\text {th }}$ of September 2020 in Switzerland, and was devoted to the vegetation of open habitats in the subalpine and alpine zones. In total, 26 EDGG Biodiversity Plots (nested plots with grain sizes of 0.0001 to $100 \mathrm{~m}^{2}$ ) were sampled in different open habitat types (grasslands, heathlands, screes, snowbeds, fens) in three regions of Switzerland, both over acidic and base-rich bedrock. Additionally, three normal plots of $10 \mathrm{~m}^{2}$ were sampled in high-elevation Festuco-Brometea stands in Zermatt. Across all grain sizes, stands showed 10-25\% higher means and 50-94\% higher maxima for total richness of vascular plants, terricolous bryophytes and lichens compared with data from the $12^{\text {th }}$ EDGG Field Workshop in dry and semi-dry grasslands of the central valleys of the Swiss Alps. We found outstanding preliminary maxima of total richness of 61, 109 and 163 species in 1, 10 and 100 $\mathrm{m}^{2}$ respectively, in an unused alpine grassland over limestone (Seslerion). Both particularly variable and partly extremely rich was the bryophyte and lichen flora of the analysed stands, with up to 33 bryophyte and 22 lichen species in $10-\mathrm{m}^{2}$ plots. We report the liverwort Cephaloziella dentata as new for Switzerland, found in a thermophilous subalpine heathland at Alp Glivers, Surselva, Grisons. Overall, our preliminary data suggest that some of the sampled subalpine and alpine habitats are among the most species-rich communities at small scales if bryophytes and lichens are also considered. Based on this finding, we recommend that these two taxonomic groups be more regularly included in surveying and particularly in monitoring programs for vegetation. The Scientific Report is supplemented by a photo diary that provides impressions of work and life during the Field Workshop.

Keywords: alpine grassland; biodiversity; bryophyte; Cephaloziella dentata; dwarf shrub heath; elevational gradient; Eurasian Dry Grassland Group (EDGG); fen; Festuco-Brometea; lichen; nested plot; scree; Seslerion; snow bed; soil pH; species richness; Switzerland; vascular plant.

Nomenclature: Juillerat et al. (2017) for vascular plants; Meier et al. (2013) for bryophytes; Nimis et al. (2018) for lichens; Mucina et al. (2016) for syntaxa.

Abbreviation: EDGG = Eurasian Dry Grassland Group.

Submitted: 8 October 2020; first decision: 11 October 2020; accepted: 11 October 2020

Scientific Editor: Riccardo Guarino 


\section{Introduction}

Field Workshops (formerly called Research Expeditions) are a major element of the annual activities of the Eurasian Dry Grassland Group (EDGG) (see Vrahnakis et al. 2013). In May 2020, the planned $14^{\text {th }}$ Field Workshop in Ukraine (Vynokurov et al. 2019) had to be cancelled and postponed to 2021 due to the Corona pandemic. This prompted some of the regular participants of EDGG Field Workshops to organise an ad-hoc event in late summer, when the infection rates throughout Europe were relatively low and people from several countries could travel. We chose the subalpine and alpine open habitats of Switzerland as the target for two reasons: (1) these habitats can still be sampled quite well in September, as they contain only a very small fraction of therophytes and geophytes (see Baumann et al. 2016) and (2) while dry grasslands at lower elevations are very well represented in the GrassPlot database (Dengler et al. 2018; Biurrun et al. 2019), alpine grasslands and particularly non-grassland habitats of the subalpine and alpine zones, such as dwarf-shrub heaths, snow beds, screes and moraines, as well as fens, are largely underrepresented. This means that we lack knowledge on scale-dependent biodiversity patterns in these habitats, particularly when it comes to bryophytes and lichens, which are known to play a much bigger role within these habitats than in the lowlands.

EDGG has decided to call this ad-hoc event the $14^{\text {th }}$ EDGG Field Workshop as we used the standardised EDGG methodology (Dengler et al. 2016) and will contribute the data to the EDGG-affiliated GrassPlot database (Dengler et al. 2018; Biurrun et al. 2019; https://edgg.org/databases/GrassPlot) for overarching studies. In this contribution, we report on the $14^{\text {th }}$ Field Workshop (including a photo diary in the Appendix) and provide some preliminary results.

\section{The $14^{\text {th }}$ EDGG Field Workshop}

The Field Workshop was attended by nine people from four countries (Switzerland, Germany, Poland and China) (Fig. 1). Since several colleagues participated only partially, there were on average 5.7 people present on each of the 10 sampling days.

We sampled in three different regions (Fig. 2, Table 1) to reflect geological and biogeographical differences: (1) the Glarus Alps (cantons Glarus and Uri) with base-rich bedrock; (2) Surselva (canton Grisons) with acidic bedrock and (3) around Zermatt (canton Valais) with both acidic (Fig. 3) and base-rich bedrock (Fig. 4). In each of the three regions we

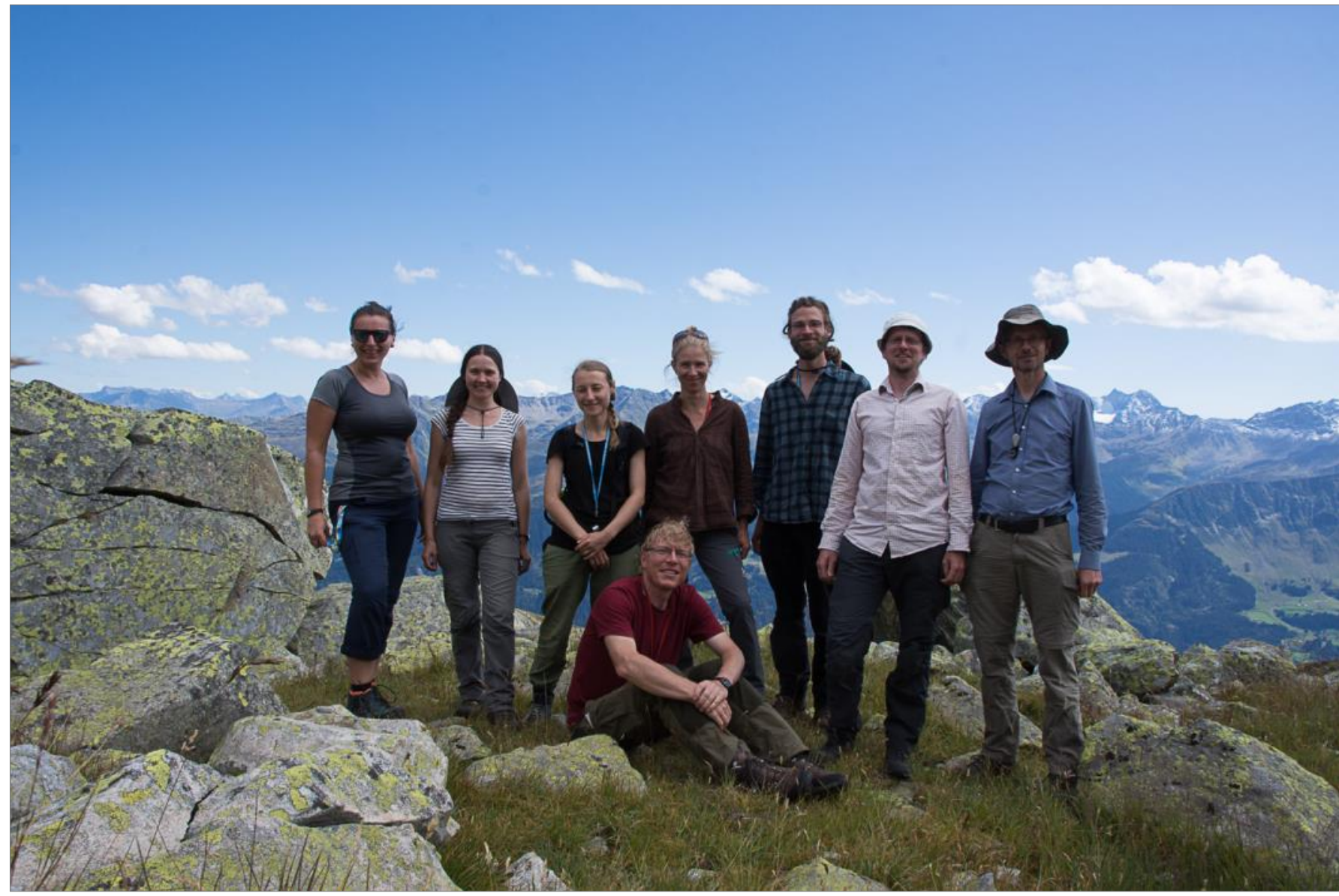

Fig. 1. The Field Workshop team on $\mathbf{5}$ September 2020 above Alp Glivers, Surselva, Switzerland. From left to right standing: Beata Cykowska-Marzencka, Iwona Dembicz, Hallie Seiler, Susanne Riedel, Timon Bruderer, Patrick Neumann and Christian Dolnik; in the front: Jürgen Dengler. Jinghui Zhang is missing in this photo, since he only participated in the last third of the Field Workshop. Photo: J. Dengler. 

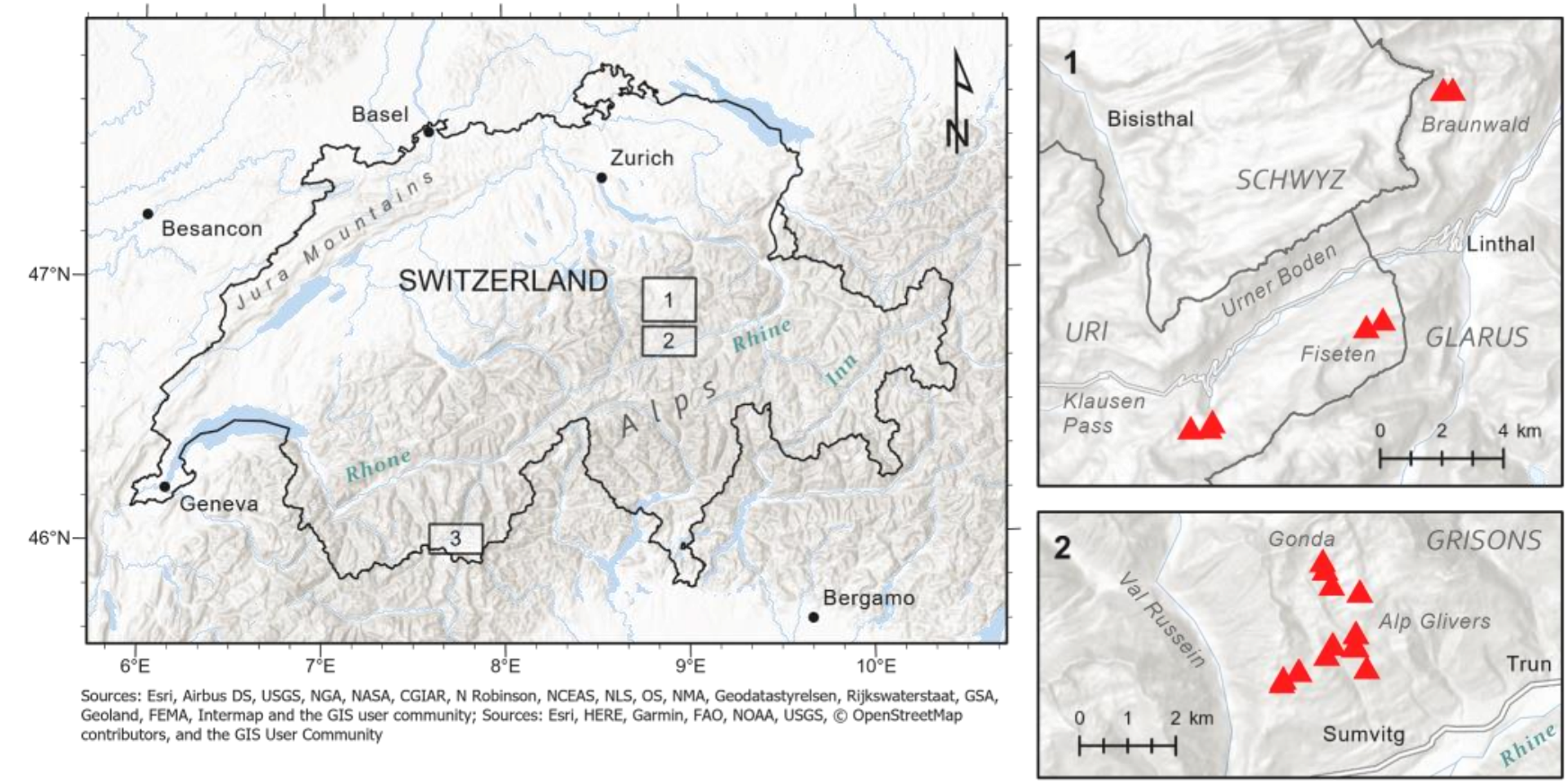

Ge contributors, and the GIS User Community

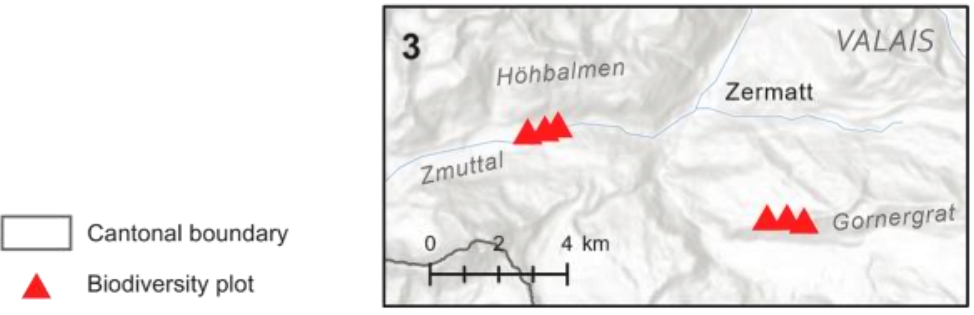

Fig. 2. Distribution of the sampling sites of the $14^{\text {th }}$ EDGG Field Workshop in four cantons of Switzerland (Valais, Uri, Glarus and Grisons). Prepared by H. Seiler.

tried to cover the diversity of open habitat types of the subalpine and alpine zones as far as this was possible within the limited time. This means that we included both natural and secondary habitats, both with current landuse (i.e. livestock grazing) and without. We spread our plots across the main habitat types found at this elevation: grasslands (both livestock-grazed and unused), heathlands (both low and tall), screes, moraines, snowbeds and fens (Table 1; Figs. 3 and 4). Our plots of subalpine and alpine habitats were located at elevations between 1,874 and 3,076 $\mathrm{m}$ a.s.l. They ranged from $45.98^{\circ}$ to $46.96^{\circ}$ northern latitude and from $7.68^{\circ}$ to $8.98^{\circ}$ eastern longitude. While mean annual temperature varied only from -1.9 to $+1.4{ }^{\circ} \mathrm{C}$, the variability in mean annual precipitation was more pronounced, ranging from 613 to $1,908 \mathrm{~mm}$ (Fig. 5).

In total, we sampled 26 nested-plot series ("EDGG biodiversity plots"; Fig. 6) with grain sizes of $0.0001-100 \mathrm{~m}^{2}$ (Table 1). Additionally, we sampled three $10-\mathrm{m}^{2}$ plots ("normal plots" in EDGG terminology: Dengler et al. 2016) of highelevation Festuco-Brometea communities in Zermatt (Fig. 7) to complement the data of the $12^{\text {th }}$ EDGG Field Workshop (Dengler et al. 2020). Our plots are permanently marked with soil magnets to allow future resampling to analyse possible changes of the vegetation due to global change.

\section{Initial results and discussion}

\section{Floristic composition and species of special interest}

The most frequent vascular plants in the subalpine and alpine habitats of the three regions (based on the $5210-\mathrm{m}^{2}$ plots) were Leontodon helveticus (44\%), Anthoxanthum odoratum aggr. (38\%), Campanula scheuchzeri (38\%), Nardus stricta (37\%) and Vaccinium myrtillus (33\%). Among the bryophytes, Racomitrium canescens aggr. (33\%), Pleurozium schreberi (31\%), Polytrichum juniperinum (25\%) and Weissia spp. (25\%) were most widespread. Finally, among the lichens, Cetraria islandica (29\%), Cladonia arbuscula (19\%) and Cladonia macroceras (17\%) reached the highest constancy. In all of these cases, such high constancies indicate that species have low affinity to specific vegetation types and often occur over both siliceous and limestone bedrock.

In one plot, we found the foliose liverwort Cephaloziella dentata (Raddi) Mig., which is the first record for Switzerland (i.e. the species is not included in Meier et al. 2013). 
Table 1. Overview of the sites studied during the $14^{\text {th }}$ EDGG Field Workshop 2020.

\begin{tabular}{|c|c|c|c|c|c|c|}
\hline Plot & Date & Canton & Municipality & Location & Bedrock & Vegetation type \\
\hline $\mathrm{CHA01}$ & 4.09 .20 & Grisons & Sumvitg & Alp Glivers & acidic & Grassland (grazed) \\
\hline $\mathrm{CHA02}$ & 4.09 .20 & Grisons & Sumvitg & Alp Glivers & acidic & Heathland (tall) \\
\hline $\mathrm{CHA03}$ & 5.09 .20 & Grisons & Sumvitg & Gonda & acidic & Scree \\
\hline $\mathrm{CHA04}$ & 5.09 .20 & Grisons & Sumvitg & Gonda & acidic & Grassland (unused) \\
\hline CHA05 & 5.09 .20 & Grisons & Sumvitg & Gonda & acidic & Snowbed \\
\hline CHA06 & 5.09 .20 & Grisons & Sumvitg & Alp Glivers & acidic & Heathland (low) \\
\hline $\mathrm{CHA07}$ & 6.09 .20 & Grisons & Sumvitg & Alp Glivers & acidic & Heathland (tall) \\
\hline $\mathrm{CHA08}$ & 6.09 .20 & Grisons & Sumvitg & Alp Glivers & acidic & Fen \\
\hline CHA09 & 7.09 .20 & Grisons & Sumvitg & Alp Crap Ner & acidic & Heathland (tall) \\
\hline CHA10 & 7.09 .20 & Grisons & Sumvitg & Alp Crap Ner & acidic & Snowbed \\
\hline CHA11 & 7.09 .20 & Grisons & Sumvitg & Alp Crap Ner & acidic & Heathland (low) \\
\hline CHA12 & 7.09 .20 & Grisons & Sumvitg & Alp Crap Ner & acidic & Heathland (tall) \\
\hline $\mathrm{CHA} 13$ & 7.09 .20 & Grisons & Sumvitg & Alp Glivers & acidic & Grassland (grazed) \\
\hline CHA14 & 9.09 .20 & Valais & Zermatt & Zmutttal & base-rich & Moraine \\
\hline CHA15 & 9.09 .20 & Valais & Zermatt & Zmutttal & base-rich & Scree \\
\hline CHA16 & 9.09 .20 & Valais & Zermatt & Zmutttal & base-rich & Grassland (unused) \\
\hline $\mathrm{CHA} 17$ & 10.09 .20 & Valais & Zermatt & Gornergrat & acidic & Scree \\
\hline CHA18 & 10.09 .20 & Valais & Zermatt & Gornergrat & acidic & Snowbed \\
\hline CHA19 & 10.09 .20 & Valais & Zermatt & Gornergrat & acidic & Grassland (grazed) \\
\hline $\mathrm{CHA} 20$ & 12.09 .20 & Glarus & Braunwald & Gumen & base-rich & Scree \\
\hline $\mathrm{CHA} 21$ & 12.09 .20 & Glarus & Braunwald & Gumen & base-rich & Grassland (grazed) \\
\hline CHA22 & 13.09 .20 & Uri & Urnerboden & Im Gries & base-rich & Moraine \\
\hline CHA23 & 13.09 .20 & Uri & Urnerboden & Im Gries & base-rich & Snowbed \\
\hline $\mathrm{CHA} 24$ & 13.09 .20 & Uri & Urnerboden & Im Gries & base-rich & Heathland (low) \\
\hline CHA25 & 14.09 .20 & Uri & Urnerboden & Fisetengrat & base-rich & Grassland (unused) \\
\hline $\mathrm{CHA} 26$ & 14.09 .20 & Uri & Urnerboden & Fisetengrat & base-rich & Grassland (unused) \\
\hline
\end{tabular}

The plot was located on Arctostaphylos uva-ursi heathland on a steep south-facing slope on Alp Glivers (Plot CHA07; $46.7508^{\circ}$ northern latitude, $8.9317^{\circ}$ eastern longitude, 2,080 m a.s.l.). According to Paton (1999), this species occurs in southern Great Britain, where it is known only from a few sites in Erica vagans-Calluna heathlands of western Cornwall. The species has also been recorded in Mediterranean countries such as Spain, France, Sardinia, Sicily, Italy, former Yugoslavia and Turkey, as well as Denmark, Sweden, and Madeira (Paton 1999; Damsholt 2002; Keçelı \& Çetın 2006). As Cephaloziella species belong to the smallest hepatics of our flora, they are easily overlooked. Diagnostic features of $\boldsymbol{C}$. dentata are its minutely toothed leaves and the typical tuberculate gemmae on the tips of some leaves.

\section{Phytodiversity}

Our phytodiversity data are preliminary, as some critical vascular plants and more bryophytes and lichens have yet to be determined or confirmed in the lab. This should not create a systematic bias in our data for the grain sizes between 0.0001 and $10 \mathrm{~m}^{2}$, as something recognised as a different species in the field will likely remain a different species irrespective of the final determination. However, for the $100-\mathrm{m}^{2}$ grain size, our preliminary richness data will likely overestimate the true richness by approx. 5-10\%, as the same species might have been collected under a different "field name" in both corners.

We found that mean total species richness (i.e. vascular plants + terricolous bryophytes and lichens) increased from 2.7 species in $0.0001 \mathrm{~m}^{2}$ to 22.8 species in $1 \mathrm{~m}^{2}$, and again from 38.1 species in $10 \mathrm{~m}^{2}$ to 69.2 species in $100 \mathrm{~m}^{2}$ (Table 2). Interestingly, these values are between $10 \%$ and $25 \%$ higher than the means found last year in the dry and semidry grasslands of the central valleys of the Swiss Alps (Dengler et al. 2020). However, means only tell part of the story; in the subalpine and alpine vegetation we found much larger variability in richness across all scales than in the xerothermic vegetation in the lower parts of these valleys. Actually, all of our minima for the subalpine and alpine open vegetation (excluding values of 0 ) were lower, and the maxima were all higher. Particularly striking is the difference in the maxima, which were between $50 \%$ and $94 \%$ higher than those from the xerothermic grasslands of the same regions. The increase was strongest for grain sizes of $1 \mathrm{~m}^{2}$ and larger, with increases of $80 \%$ and more (despite having more replicates at lower elevations): 61 vs. 33 species in 1 

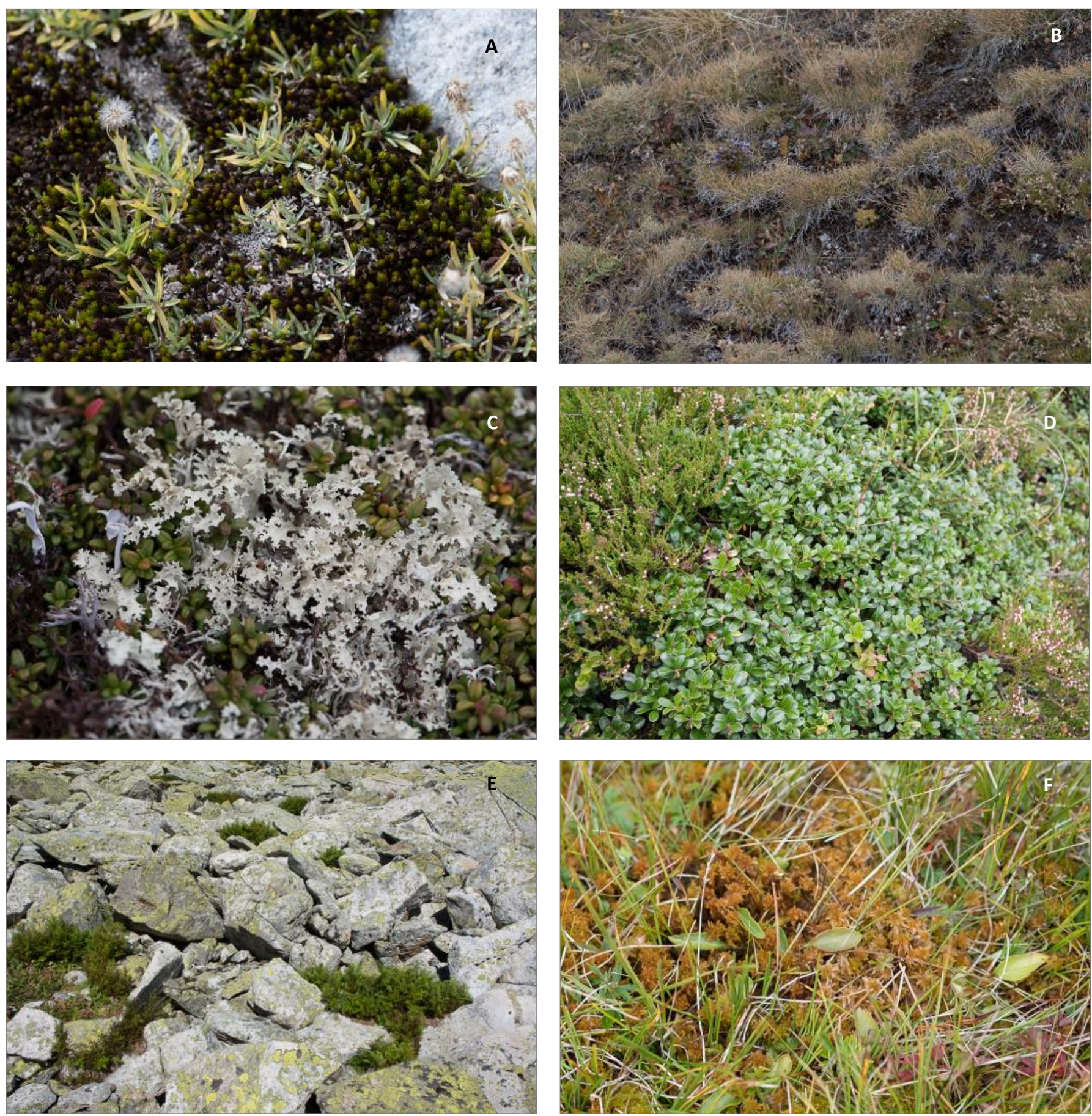

Fig. 3. Examples of the main vegetation types studied over acidic bedrock: (a) snowbed vegetation with Gnaphalium supinum and Polytrichastrum sexangulare; (b) alpine grassland with Festuca halleri aggr.; (c) low-grown wind-exposed alpine heath with Loiseleuria procumbens and Flavocetraria nivalis; (d) taller, thermophilous subalpine heath with Arctostaphylos uva-ursi and Calluna vulgaris; (e) scree with Cryptogramma crispa; (f) fen with Sphagnum inundatum. Photos: J. Dengler. 

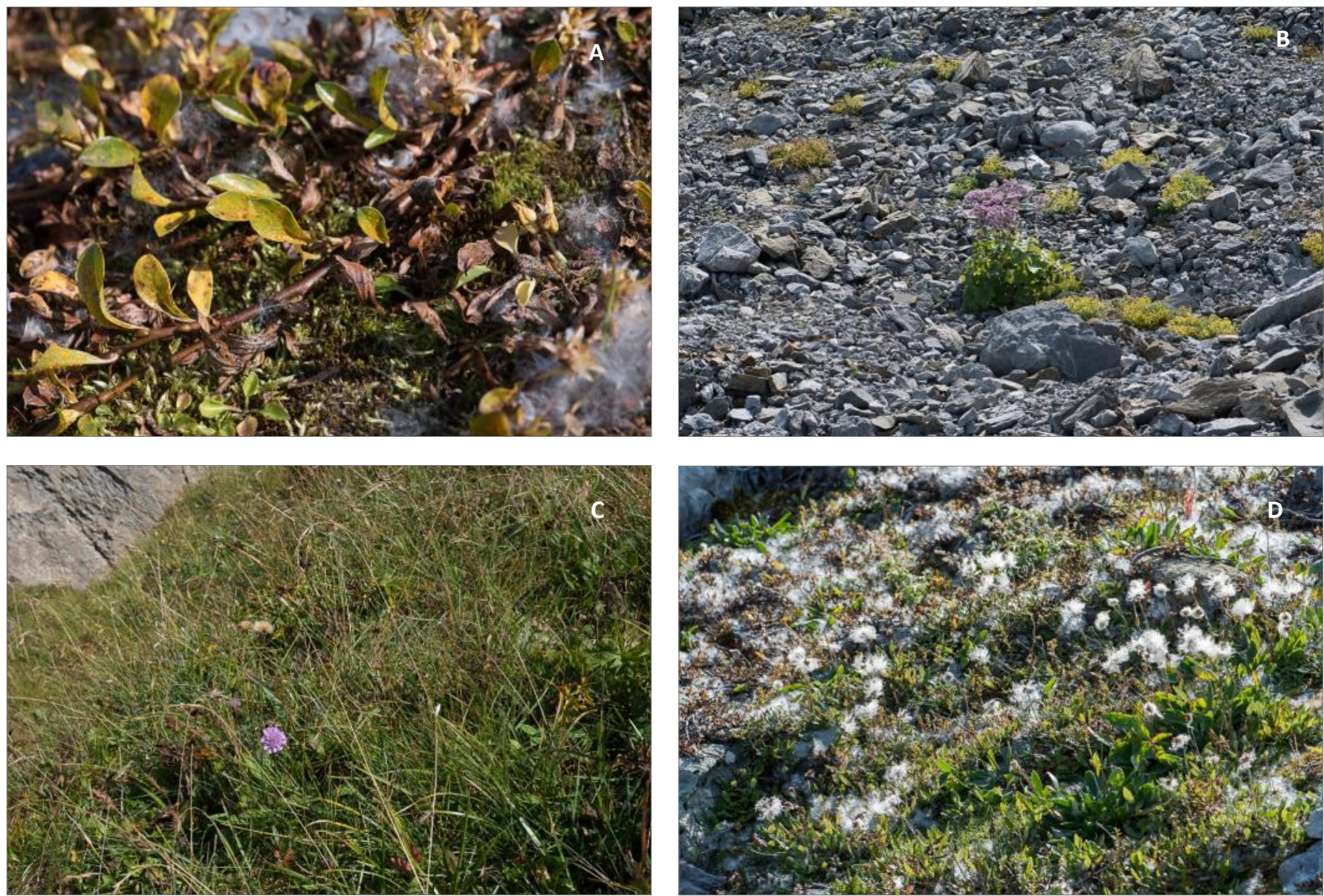

Fig. 4. Examples of the main vegetation types studied over limestone. (a) snowbed vegetation with Salix retusa; (b) vegetation on a recent moraine with Adenostyles alpina and Saxifraga aizoides; (c) alpine grassland with Sesleria varia and Scaciosa lucida; (d) dwarf-shrub heath with Dryas octopetala. Photos: J. Dengler.

$\mathrm{m}^{2}, 109$ vs. 60 species in $10 \mathrm{~m}^{2}$ and 163 vs. 84 species in 100 $\mathrm{m}^{2}$. Currently, the highest values in the GrassPlot database (version 2.09 as of 4 October 2020; see Dengler et al. 2018; Biurrun et al. 2019) are 159 for a mesoxeric grassland in Armenia (Aleksanyan et al. 2020), 146 for a mesoxeric grassland in the White Carpathians, Czech Republic, and 134 and 129 species for mesoxeric grasslands in the Transylvanian Plateau, Romania. However, as the final species determination has not yet been completed for the Armenian dataset, its species richness will likely be slightly lower than initially reported. So, there is a good chance that our plot will become the new Palaearctic record holder, presumably with 150-155 species after determination and correction. Interestingly, all the hitherto top-ranked plots for total species richness in $100 \mathrm{~m}^{2}$ (the named ones and some more) belong to the order Brachypodietalia pinnati (class FestucoBrometea), while our stand is from the alliance Seslerion caeruleae (class Elyno-Seslerietea). While this plot could likewise be considered a mesoxeric, basiphilous grassland, it is also a natural grassland above the timberline and at least currently ungrazed, unlike the other top-ranked plots, all of them secondary, semi-natural grasslands.

While our total richness values are outstanding, at least for the more diverse habitats, those for vascular plants are high, but not exceptional, when compared to other grassland types. For bryophytes and lichens, the story is different. Bryophyte and lichen richness varied widely; in $10 \mathrm{~m}^{2}$, for example, we found between 0 and 33 bryophyte species and between 0 and 22 lichen species (Table 2). Also, the contribution of non-vascular species to total richness varied from $0 \%$ to $73 \%$ at $10 \mathrm{~m}^{2}$. This means that in some subalpine and alpine habitats cryptogams were virtually absent, while in others they outnumbered the vascular plant species three-fold. On average, there were 8.5 bryophyte species and 4.0 lichen species in $10 \mathrm{~m}^{2}$, accounting for $32 \%$ of the total richness.

Considering the main habitat and bedrock types, we found pronounced differences in species richness (Fig. 8). The species richness of the complete vegetation (all three taxonomic groups together) and of vascular plants alone was hig- 

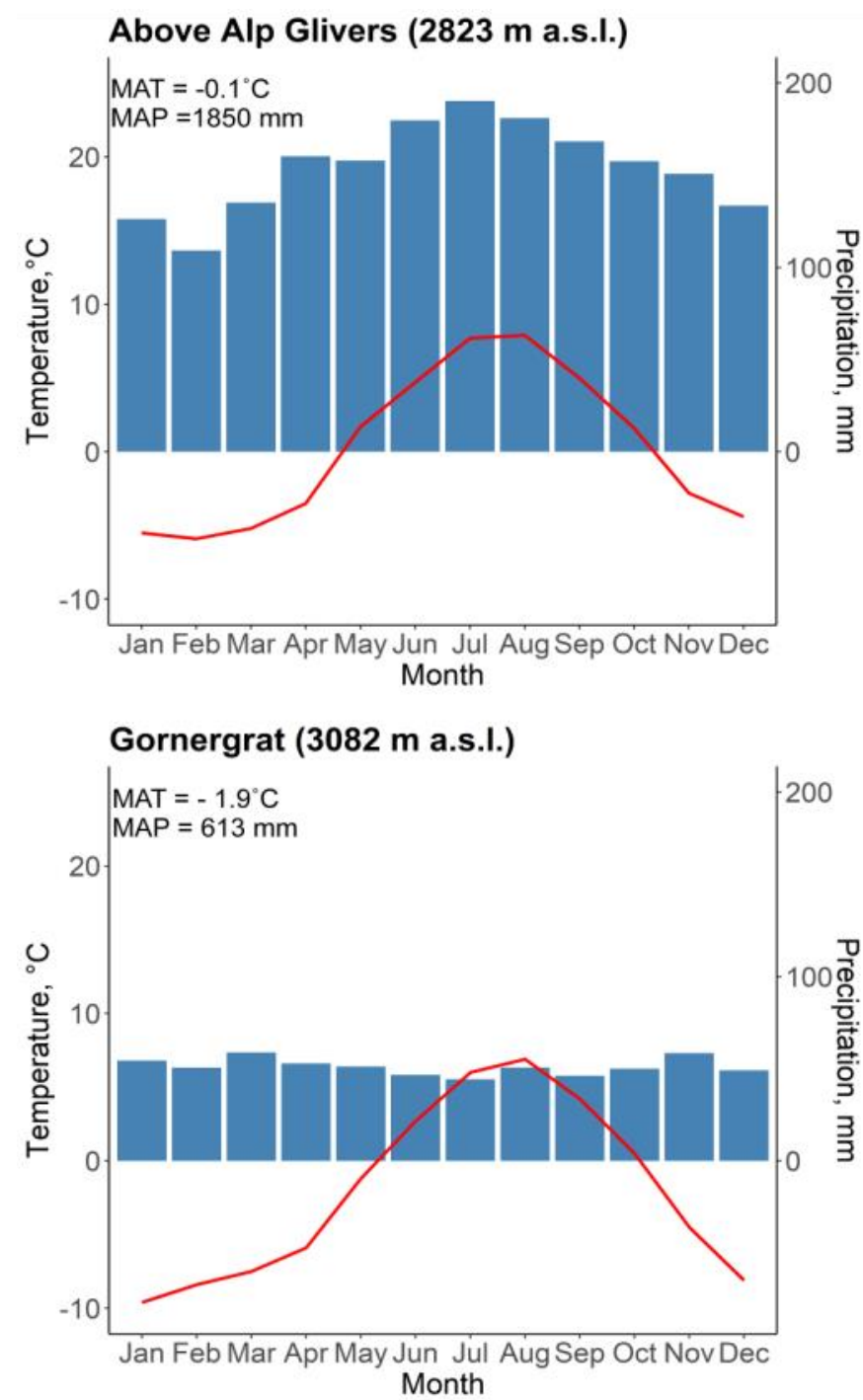
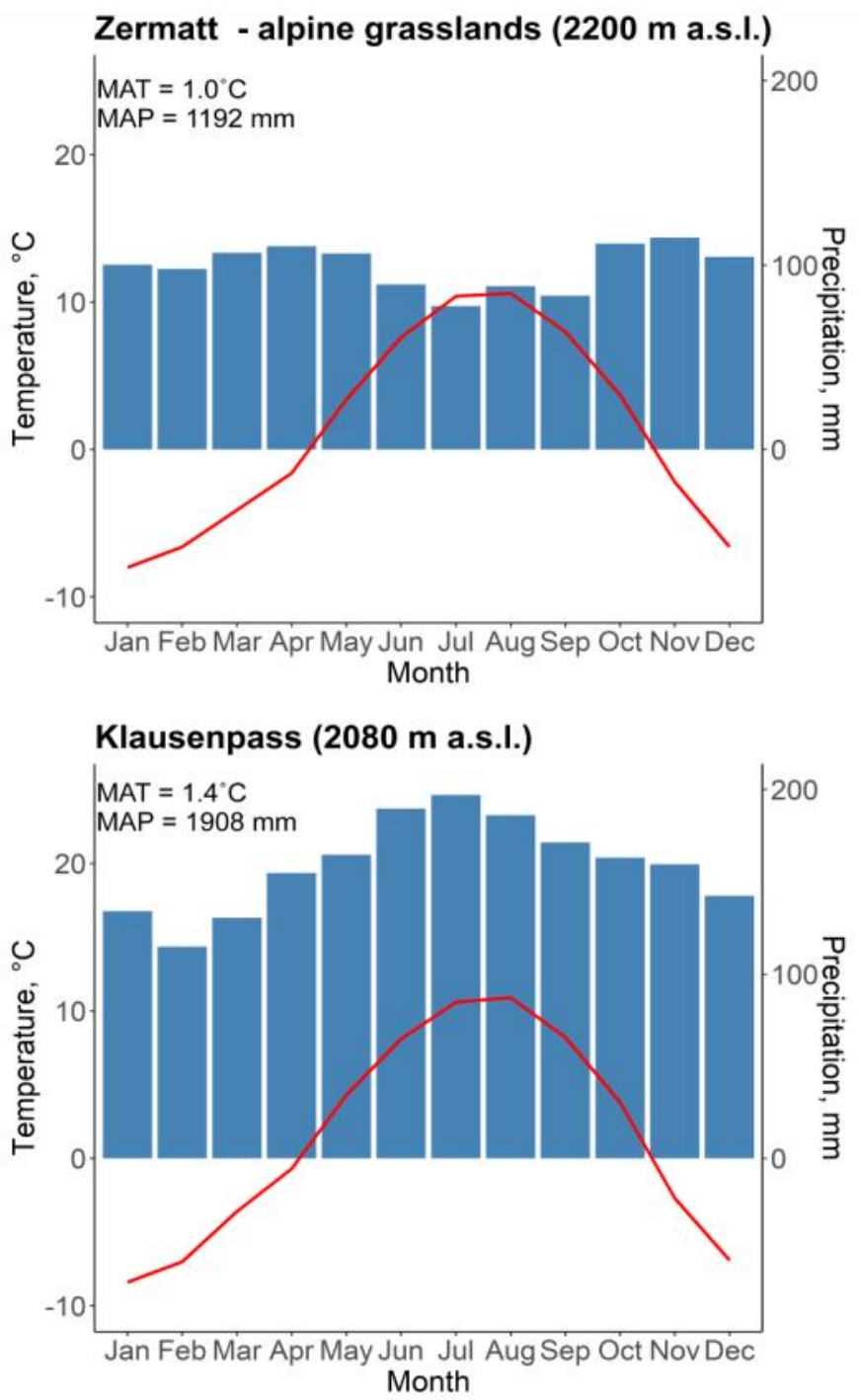

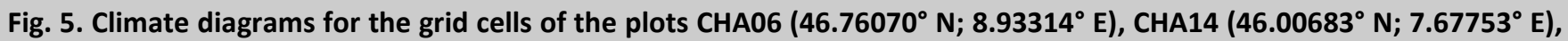
CHA17 $\left(45.98319^{\circ} \mathrm{N} ; 7.78136^{\circ} \mathrm{E}\right), \mathrm{CHA}^{23}\left(46.85907^{\circ} \mathrm{N} ; 8.87445^{\circ} \mathrm{E}\right)$ representing four main sampling areas: vicinities of Alp Glivers, vicinities of Zermatt, Gornergrat and Klausenpass, respectively. Data were obtained from CHELSA (Karger et al. 2017) in $30 \mathrm{sec}$ resolution via QGIS (QGIS Development Team 2019) and processed with the R package ggplot2 (Wickham 2016). MAT - mean annual temperature, MAP - mean annual precipitation.

Table 2. Preliminary species richness data from the $14^{\text {th }}$ EDGG Field Workshop in Switzerland. For the grain sizes from 0.0001 to $10 \mathrm{~m}^{2}$ the richness values should be more or less unbiased, but for $100 \mathrm{~m}^{2}$ the values are likely about 5-10\% too high, as the same species might have been noted under different "field names" in the two opposite corners.

\begin{tabular}{llllllllll}
\hline & & \multicolumn{2}{c}{ Total richness } & \multicolumn{2}{c}{ Vascular plants } & \multicolumn{2}{c}{ Bryophytes } & \multicolumn{2}{c}{ Lichens } \\
Area $\left[\mathbf{m}^{2}\right]$ & $\boldsymbol{n}$ & Mean & Range & Mean & Range & Mean & Range & Mean & Range \\
\hline 0.0001 & 52 & 2.7 & $0-8$ & 1.9 & $0-5$ & 0.6 & $0-5$ & 0.3 & $0-4$ \\
0.001 & 52 & 4.5 & $0-14$ & 3.1 & $0-8$ & 1.0 & $0-8$ & 0.3 & $0-6$ \\
0.01 & 52 & 7.6 & $0-22$ & 5.4 & $0-13$ & 1.6 & $0-8$ & 0.6 & $0-8$ \\
0.1 & 52 & 13.4 & $1-36$ & 9.5 & $1-23$ & 2.8 & $0-11$ & 1.2 & $0-12$ \\
1 & 52 & 22.8 & $4-61$ & 16.0 & $4-44$ & 4.9 & $0-16$ & 1.9 & $0-13$ \\
10 & 52 & 38.1 & $4-109$ & 25.5 & $4-66$ & 8.5 & $0-33$ & 4.0 & $0-22$ \\
100 & 26 & 69.2 & $27-163$ & 44.4 & $16-103$ & 16.3 & $2-45$ & 8.5 & $0-31$ \\
\hline
\end{tabular}



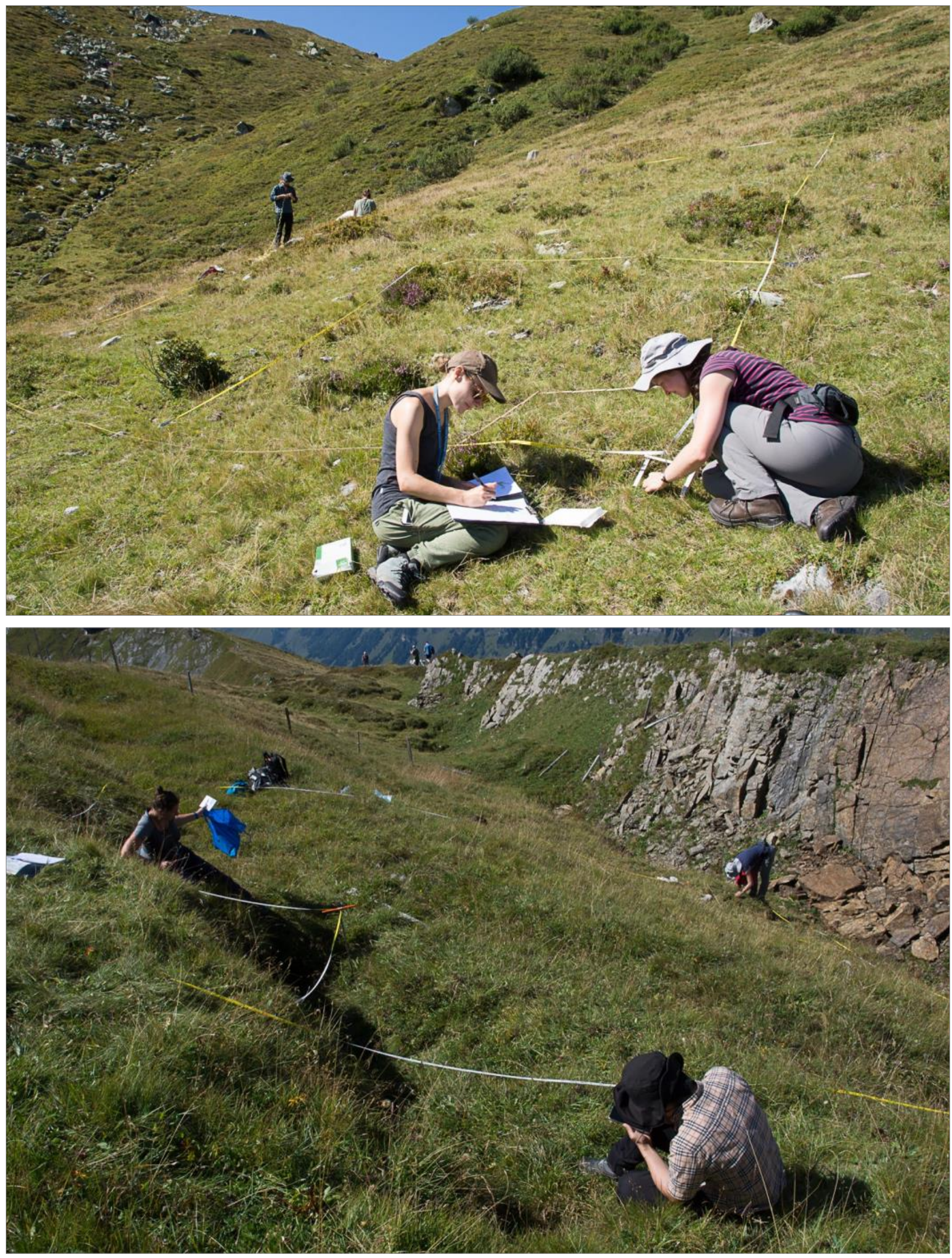

Fig. 6. Sampling of the EDGG biodiversity CHAO1 (upper photo) in a subalpine Nardus stricta grassland on Alp Glivers, Grisons, with approx. 100 species in $100 \mathrm{~m}^{2}$ and of EDGG biodiversity plot CHA25 (lower photo) in an alpine Sesleria caerulea grassland at Fissetengrat, Uri, with approx. 150 species in $100 \mathrm{~m}^{2}$. Photos: J. Dengler. 

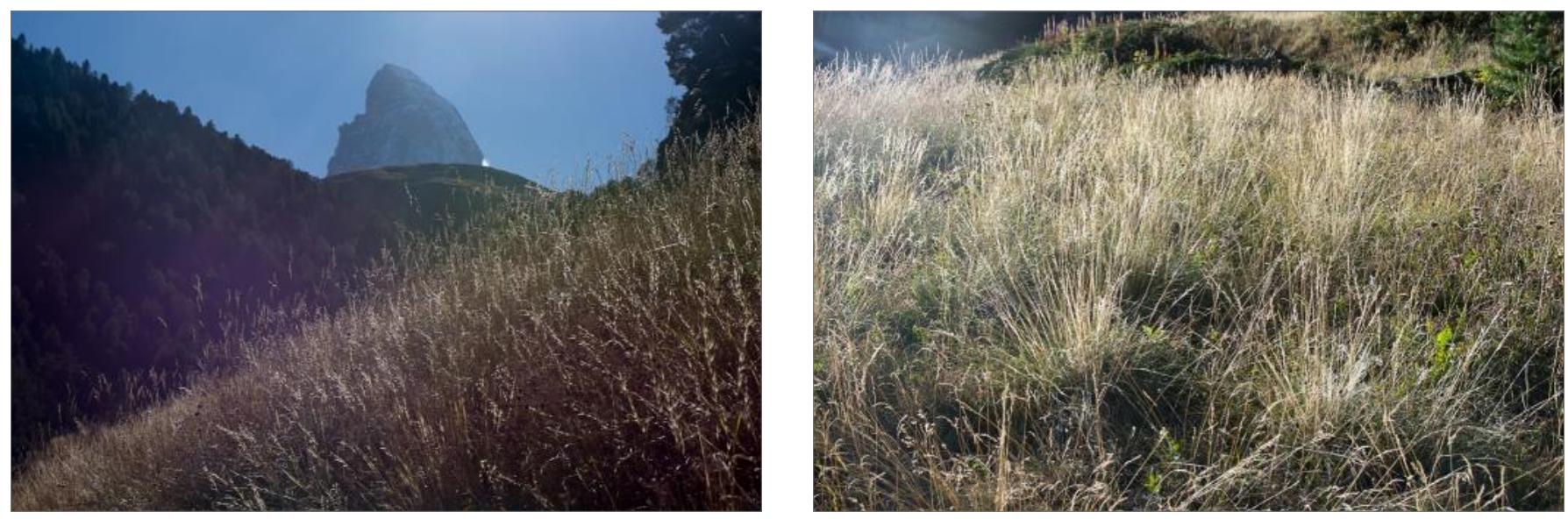

Fig. 7. In the Zmutt valley below the Matterhorn in Zermatt, we sampled three $10-\mathrm{m}^{2}$ normal plots of Festuco-Brometea stands at unusually high elevation (around $2000 \mathrm{~m}$ a.s.I.), with Stipa pennata, Bromus erectus and various Festuca species. Photo: J. Dengler.

hest in grasslands, and lowest in screes and moraines. Bryophytes did not show large differences in diversity between habitats, except that screes and moraines were the poorest habitats. Most habitats were poor in lichen species, except acidic heathlands and acidic snowbeds.

Interestingly, bedrock type had contrasting effects on the three taxonomic groups. For those four habitat types that were sampled over both acidic and base-rich bedrock, vascular plants and bryophytes had consistently higher median richness in the base-rich subtype, whereas the opposite was the case for lichens (except screes and moraines where lichen richness was equally low irrespective of bedrock chemistry) (Fig. 8). Taking all three taxonomic groups together still resulted in higher richness of base-rich vs. acidic subtypes in the case of grasslands, screes and moraines, whereas total richness values were very similar in the case of heathlands and snowbeds. While for lowland habitats in Central and Northern Europe it is a well-known phenomenon that base-rich types are more species-rich in vascular plants than their acidic counterparts (Ewald 2003; Schuster \& Diekmann 2003), this has to our knowledge not been systematically shown for subalpine and alpine habitats before, except for mires (Sekulová et al. 2013), where we did not have a paired sampling. For alpine habitats in Switzerland at the $1-\mathrm{m}^{2}$ grain size, Vonlanthen et al. (2006) found a unimodal relationship of vascular plant species richness to soil $\mathrm{pH}$ with a peak around $\mathrm{pH}=5.5$. Thus, in subsequent analyses, we will have to address the reasons for this apparent discrepancy. It could be the different grain size $\left(1 \mathrm{~m}^{2}\right.$ instead of $10 \mathrm{~m}^{2}$ ), pooling all habitat types in one analysis instead of habitat-specific comparisons, using the actual $\mathrm{pH}$ of the upper soil horizon vs. the bedrock type or a combination thereof. Additionally, the similar pattern for bryophytes and the largely reversed pattern for lichens have not been generally acknowledged previously. The constrasting behaviour of the three taxonomic groups underlines the necessity to take non-vascular taxa into account when studying biodiversity patterns of vegetation.

\section{Conclusions and outlook}

The preliminary data already demonstrate that the vegetation types of open alpine and subalpine areas in the Alps are particularly species rich, with some types even comparable to mesoxeric basiphilous grasslands in terms of total species richness. We also found that richness in these elevational belts seems to be more variable than in the lowlands (i.e. both minima lower and maxima higher), which is probably attributable to higher small- to medium-scale variability in topography and soil conditions. Also striking was the high average contribution of bryophytes and lichens to total richness, which together occasionally outnumbered vascular plant species three-fold. This finding suggests that for proper biodiversity monitoring, at least within these elevational belts, the non-vascular plants should be considered. By contrast, of the three national biodiversity monitoring programs of Switzerland (BDM: Koordinationsstelle, 2014; WBS: Bergamini et al. 2019; ALL-EMA: Riedel et al. 2018), only BDM currently considers bryophytes, and none of them consider lichens.

We plan to finalise the identification of the remaining critical vascular plant, bryophyte and lichen species by the end of the year. Major parameters of the collected soil samples will be analysed concurrently, according to EDGG standards (Dengler et al. 2016). Once these steps are completed, we intend to use our dataset to prepare a study of scale- and taxon dependent patterns and drivers of vegetation diversity in these habitat types. As soon as the vegetation data are ready, they will also be integrated in the GrassPlot database (Dengler et al. 2018; Biurrun et al. 2019) and the emerging Swiss national vegetation database ("Veg. $\mathrm{CH}^{\prime}$ ) and via these in the European Vegetation Archive (EVA; Chytrý et al. 2016) and the global plot database "sPlot" (Bruelheide et al. 2019) to allow the best possible use. Moreover, the floristic information will be fed into the database of the National Data and Information Center on the Swiss Flora ("Info Flora"; https://www.infoflora.ch), bryophytes ("Swissbryophytes"; 

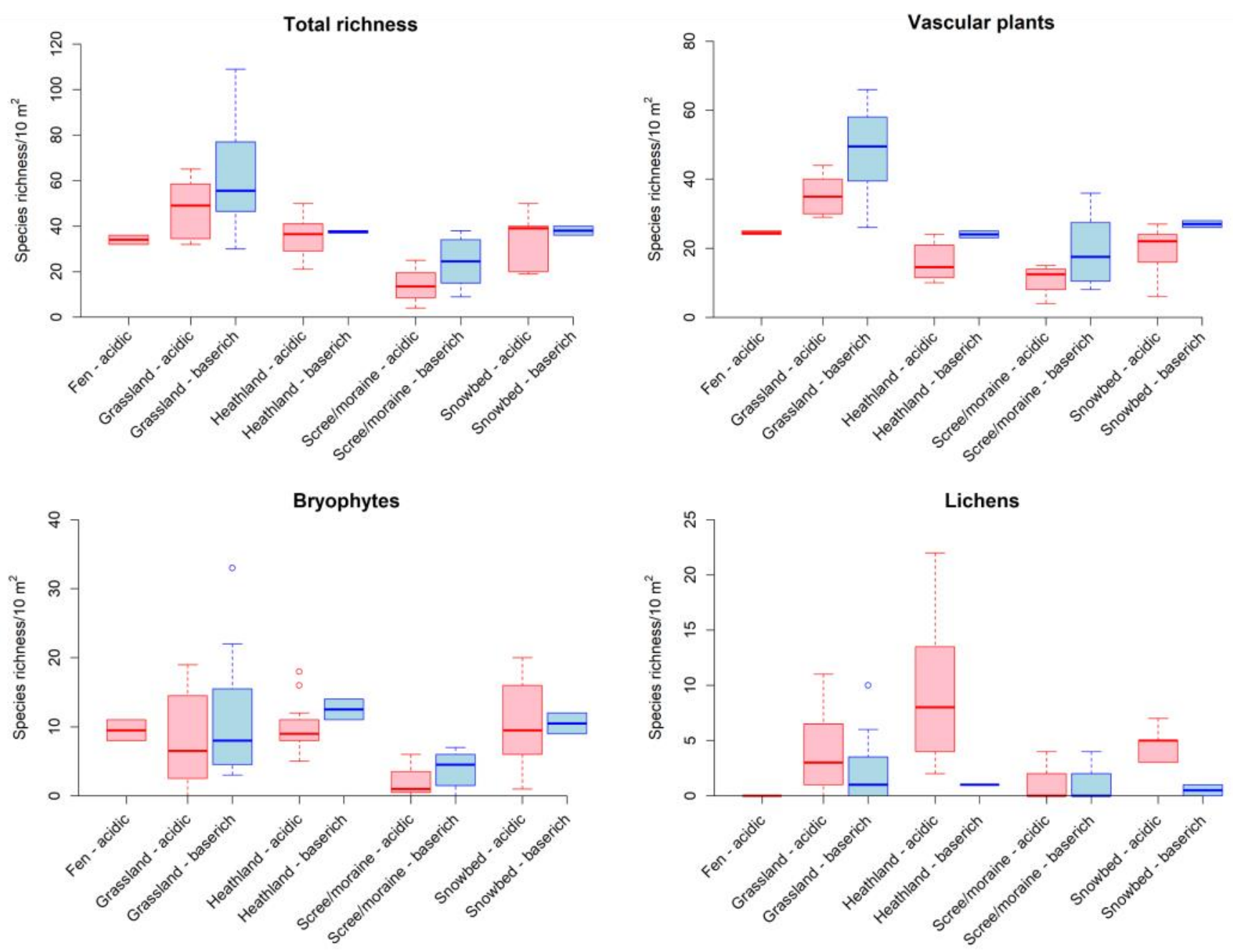

Fig. 8. Variability of species richness at $10 \mathrm{~m}^{2}$, aggregated by main structural vegetation types and differentiated according to bedrock chemistry.

https://www.swissbryophytes.ch/)

("Swisslichens"; Stofer et al. 2019).

While all previous EDGG Field Workshops focussed mainly or exclusively on dry grasslands at lower elevations, our sampling demonstrates that widening the scope of the Field Workshops to all natural and semi-natural open habitat types of the Palaearctic (corresponding to the scopes of EDGG and GrassPlot) makes sense. There are large gaps in our understanding of diversity patterns for many such habitats, particularly those within the subalpine and alpine belts of the Palaearctic.

\section{Author contributions}

J.D. organised the Field Workshop. All co-authors helped with the field sampling and plant determination. J.D. drafted the report, I.D. prepared the climate diagrams and boxplots and H.S. the maps, while B.C.-M. composed the photo diary. All authors checked, improved and approved the manuscript.

\section{References}

Aleksanyan, A., Biurrun, I., Belonovskaya, E., Cykowska-Marzencka, B., Berastegi, A., Hilpold, A., Kirschner, P., Mayrhofer, H., Shyriaieva, D., (...) \& Dengler, J. 2020. Biodiversity of dry grasslands in Armenia: First results from the 13th EDGG Field Workshop in Armenia. Palaearctic Grasslands 46: 12-51.

Baumann, E., Weiser, F., Chiarucci, A., Jentsch, A. \& Dengler, J. 2016. Diversity and functional composition of alpine grasslands along an elevational transect in the Gran Paradiso National Park (NW Italy). Tuexenia 36: 337-358.

Bergamini, A., Ginzler, C., Schmidt, B.R., Bedolla, A., Boch, S., Ecker, K., Graf, U., Küchler, H., Küchler, M., (...) \& Holderegger, R. 2019. Zustand und Entwicklung der Biotope von nationaler Bedeutung: Resultate 2011-2017 der Wirkungskontrolle Biotopschutz Schweiz. WSL Berichte 85: 1-104.

Biurrun, I., Burrascano, S., Dembicz, I., Guarino, R., Kapfer, J., Pielech, R., García-Mijangos, I., Wagner, V., Palpurina, S., (...) \& Dengler, J. 2019. GrassPlot v. 2.00 - first update on the database of multi-scale plant diversity in Palaearctic grasslands. Palaearctic Grasslands 44: 26-47.

Bruelheide, H., Dengler, J., Jiménez-Alfaro, B., Purschke, O., Hennekens, S. M., Chytrý, M., Pillar, V.D., Jansen, F., Kattge, J., 
(...) \& Zverev, A. 2019. sPlot - A new tool for global vegetation analyses. Journal of Vegetation Science 30: 161-186.

Chytrý, M., Hennekens, S.M., Jiménez-Alfaro, B., Knollová, I., Dengler, J., Jansen, F., Landucci, F., Schaminée, J.H.J., Aćić, S., (...) \& Yamalov, S. 2016. European Vegetation Archive (EVA): An integrated database of European vegetation plots. Applied Vegetation Science 19: 173-180.

Damsholt, K. 2002. Illustrated flora of Nordic liverworts and hornworts. Nordic Bryological Society, Lund, SE.

Dengler, J., Boch, S., Filibeck, G., Chiarucci, A., Dembicz, I., Guarino, R., Henneberg, B., Janišová, M., Marcenò, C., (...) \& Biurrun, I. 2016. Assessing plant diversity and composition in grasslands across spatial scales: the standardised EDGG sampling methodology. Bulletin of the Eurasian Grassland Group 32: 13-30.

Dengler, J., Wagner. V., Dembicz, I., García-Mijangos, I., Naqinezhad, A., Boch, S. Chiarucci, A., Conradi, T., Filibeck, G., (...) \& Biurrun, I. 2018. GrassPlot - a database of multi-scale plant diversity in Palaearctic grasslands. Phytocoenologia 48: 331-347.

Dengler, J., Guarino, R., Moysiyenko, I., Vynokurov, D., Boch, S., Cykowska-Marzencka, B., Babbi, M., Catalano, C., Eggenberg, S., (...) \& Dembicz, I. 2020. On the trails of Josias BraunBlanquet II: First results from the 12th EDGG Field Workshop studying the dry grasslands of the inneralpine dry valleys of Switzerland. Palaearctic Grasslands 45: 59-88.

Ewald, J. 2003. The calcareous riddle: Why are there so many calciphilous species in the Central European flora? Folia Geobotanica 38: 357-366.

Juillerat, P., Bäumler, B, Bornand, C., Eggenberg, S., Gygax, A., Jutzi, M., Möhl, A., Nyffeler, R., Sager, L. \& Santiago, H. 2017. Flora Helvetica Checklist 2017 der Gefässpflanzenflora der Schweiz. Info Flora, Bern, $\mathrm{CH}$.

Karger, D.N., Conrad, O., Böhner, J., Kawohl, T., Kreft, H., SoriaAuza, R.W., Zimmermann, N.E., Linder, H.P. \& Kessler, M. 2017. Climatologies at high resolution for the earth's land surface areas. Scientific Data 4: Article 170122.

Keçelı, T. \& Cetın, B. 2006. A contribution to the liverwort flora of the Western Black Sea Region, Northern Turkey, and a new record (Cephaloziella dentata, Cephaloziellaceae) to Southwest Asia. Cryptogamie, Bryologie 27: 459-470.

Koordinationsstelle BDM 2014. Biodiversitätsmonitoring Schweiz BDM. Beschreibung der Methoden und Indikatoren. UmweltWissen 1410: 1-104.

Meier, M.K., Urmi, E., Schnyder, N., Bergamini, A. \& Hoffmann, H. 2013. Checkliste der Schweizer Moose. Stand: 14.10.2013. Nationales Inventar der Schweizer Moosflora \& Institut für Systematische Botanik der Universität Zürich, Zurich, $\mathrm{CH}$.
Mucina, L., Bültmann, H., Dierßen, K., Theurillat, J.-P., Raus, T., Čarni, A., Šumberová, K., Willner, W., Dengler, J., (...) \& Tichý, L. 2016. Vegetation of Europe: Hierarchical floristic classification system of vascular plant, bryophyte, lichen, and algal communities. Applied Vegetation Science 19, Supplement 1: 3-264.

Nimis, P.L., Hafellner, J., Roux, C., Clerc, P., Mayrhofer, H., Martellos, S. \& Bilovitz, P.O. 2018. The lichens of the Alps - an annotated checklist. MycoKeys 31: 1-634.

Paton, J.A. 1999. The liverwort flora of the British Isles. Harley Books, Colchester, UK.

QGIS Development Team 2019. QGIS Geographic Information System. Open Source Geospatial Foundation Project. URL: http:// qgis.osgeo.org.

Riedel, S., Meier, E., Buholzer, S., Herzog, F., Indermauer, A., Lüscher, G., Walter, T., Winizki, J., Hofer, G., (...) \& Ginzler, C. 2018. ALL-EMA Methodology Report Agricultural Species and Habitats. Agroscope Science 57: 1-31.

Schuster, B., Diekmann, M. 2003. Changes in species density along the soil pH gradient - evidence from German plant communities. Folia Geobotanica 38: 367?379.

Sekulová, L., Hájek, M. \& Syrovátka, V. 2013. Vegetationencironment relationships in alpine mires of the West Carpathians and the Alps. Journal of Vegteation Science 24: 11181128.

Stofer, S., Scheidegger, C., Clerc, P., Dietrich, M., Frei, M., Groner, U., Jakob, P., Keller, C., Roth, I., (...) \& Zimmermann, E. 2019. SwissLichens - Webatlas der Flechten der Schweiz / Modul Verbreitung (Version 2). URL: http://www.swisslichens.ch [accessed on 10 January 2019].

Vonlanthen, C.M., Kammer, P.M., Eugster, W., Bühler, A. \& Veit, H. 2006. Alpine vascular plant species ricness: the improtance of daily maximum temperature and pH. Plant Ecology 184: 13-25.

Vrahnakis, M.S., Janišová, M., Rūsiṇa, S., Török, P., Venn, S. \& Dengler, J. 2013. The European Dry Grassland Group (EDGG): stewarding Europe's most diverse habitat type. In: Baumbach, H. \& Pfützenreuter, S. (eds.) Steppenlebensräume Europas Gefährdung, Erhaltungsmaßnahmen und Schutz, pp. 417-434, Thüringer Ministerium für Landwirtschaft, Forsten, Umwelt und Naturschutz, Erfurt, DE.

Vynokurov, D., Moysiyenko, I., Shyriaieva, D., Khodosovtsev, A., Dembicz, I. \& Biurrun, I. 2019. 14th EDGG Field Workshop: Ukrainian steppes along climatic gradients. Ukraine, 25 May - 3 June 2020. Second call. Palaearctic Grasslands 44: 6-15.

Wickham, H. 2016. ggplot2: Elegant graphics for data analysis. Springer, New York, US. 


\section{Appendix: Photo diary of the 14th EDGG Field Workshop}

Edited by Beata Cykowska-Marzencka \& Jürgen Dengler

With photos by Beata Cykowska-Marzencka, Iwona Dembicz, Jürgen Dengler, Patrick Neumann \& Hallie Seiler

Day 1 (4 September 2020)

Our rather spontaneous expedition started at "Stalla Alp Glivers", the mountain hut situated on Alp Glivers at $1919 \mathrm{~m}$ a.s.l. This was our starting point and sleeping place for four days. During the first afternoon after arrival, we made our first two biodiversity plots, one in grazed grassland and the second in tall heathland. They were not made without difficulties - on both plots some of us had to fight with "mountain grazing animals" to keep our measuring tapes and backpacks in good (any) condition. However, our hardships were rewarded with beautiful views, pleasant company and a delicious dinner. After dinner we were joined by two friendly lichenologists from northern Germany.
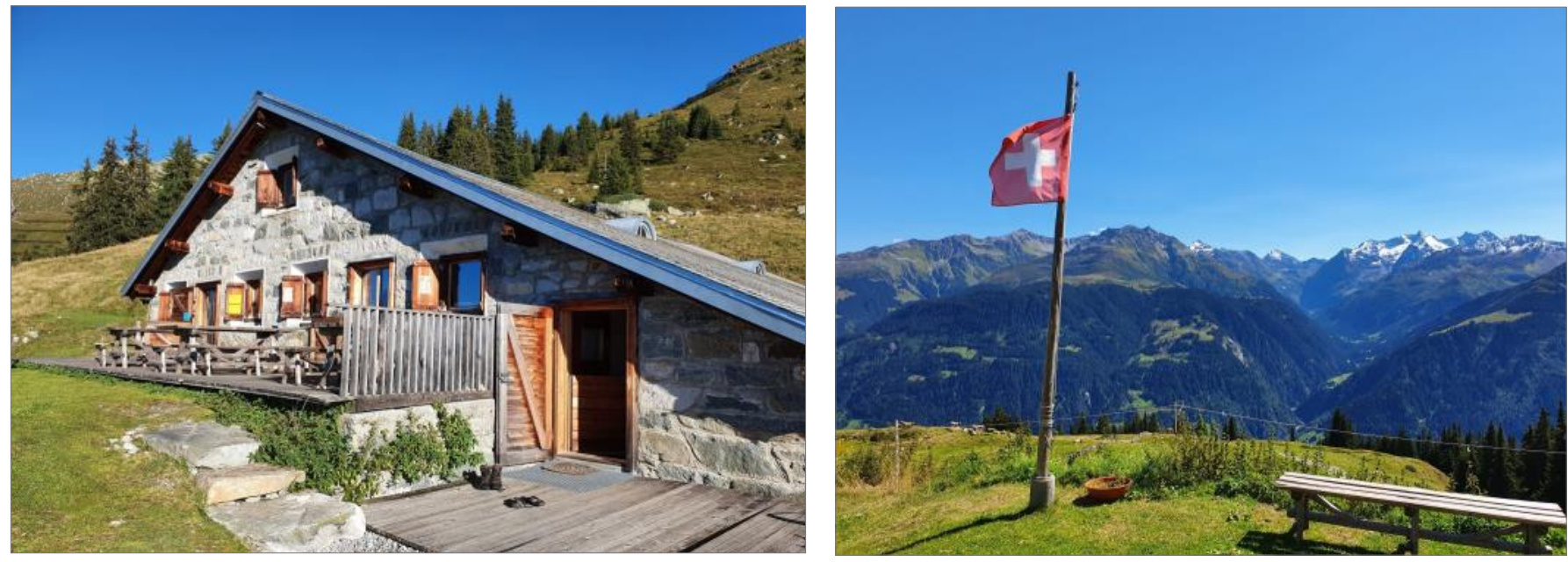

Stalla Alp Glivers and surroundings.
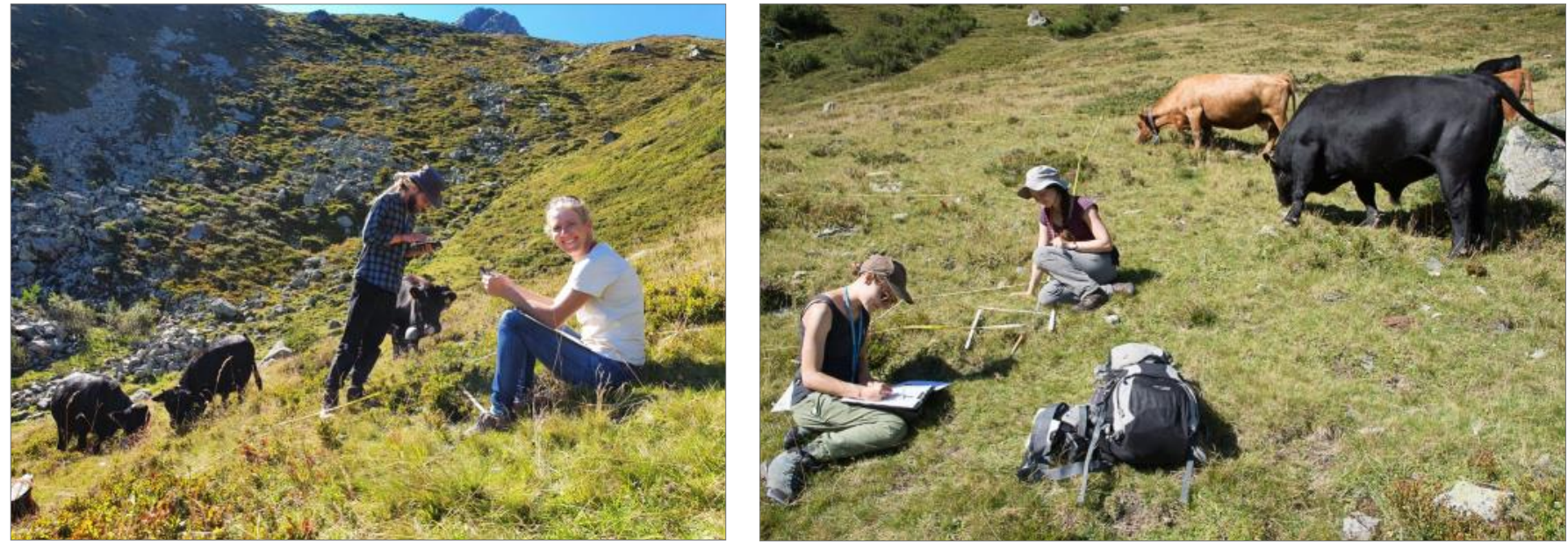

First plot CHA01 surrounded by cattle. 

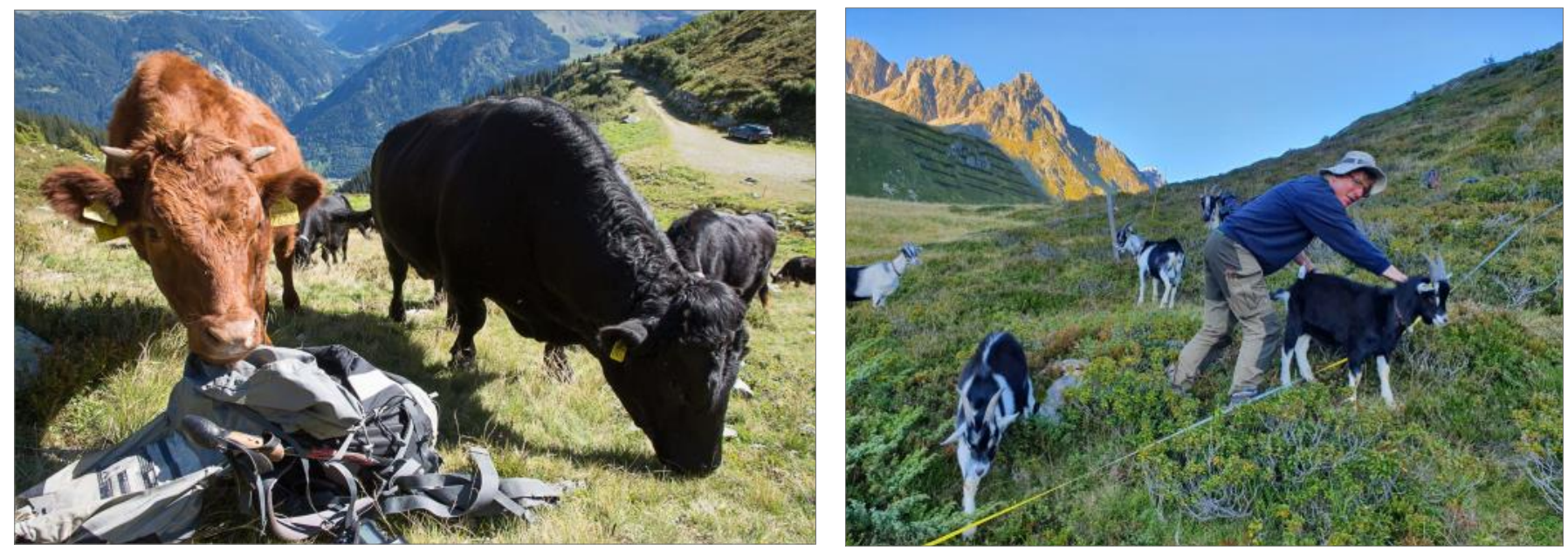

Our companions on first two plots and eaters of things, not only plants. Left: plot CHA01, right: plot CHAO2.

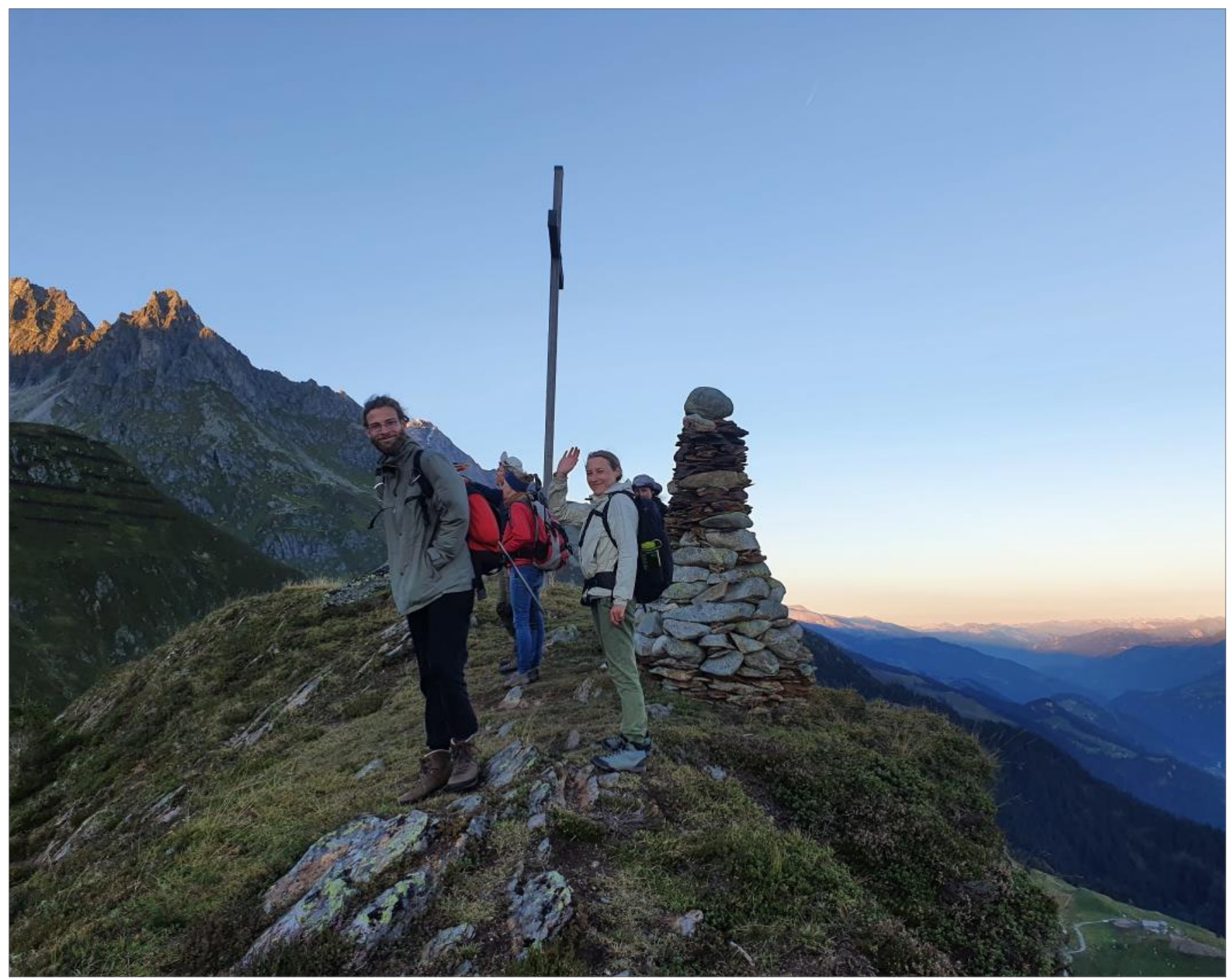

The views and company made up for the hardships. 
Day 2 (5 September 2020)

The second day started with perfect weather and a delicious breakfast in our accommodation. We ascended over 600 meters, completing four biodiversity plots along the way. Some of us also refreshed themselves in a high-mountain lake, while others had to tend the goats.
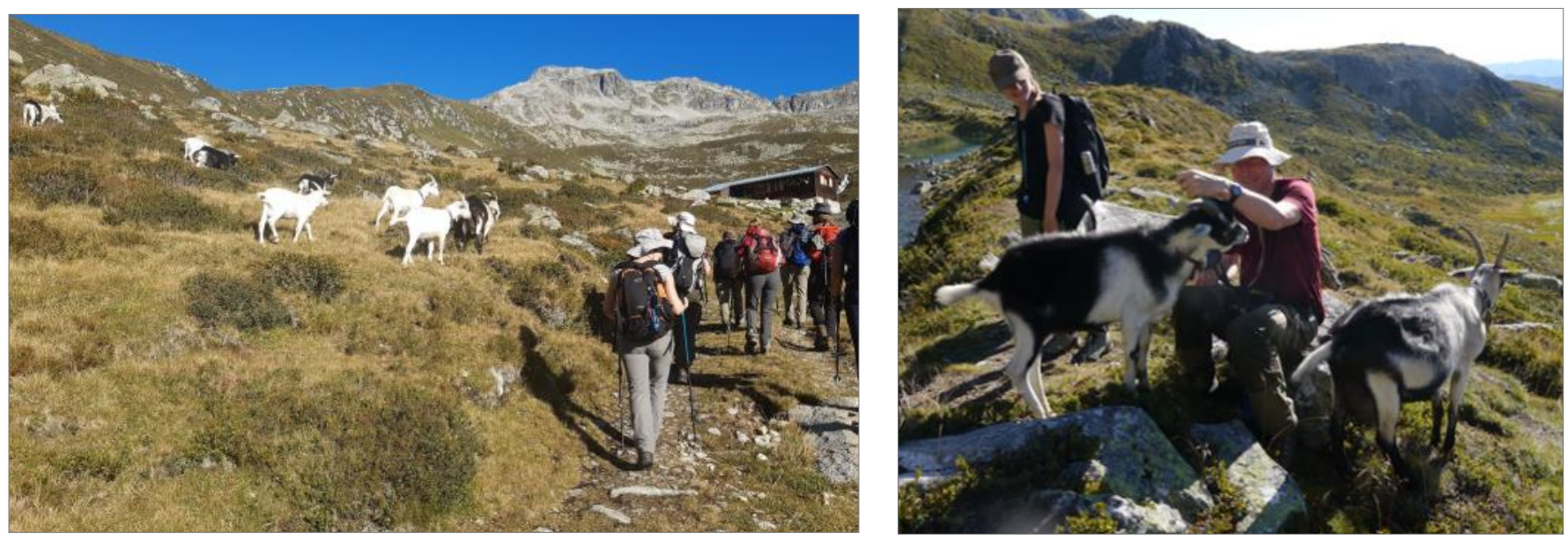

“Together forever".
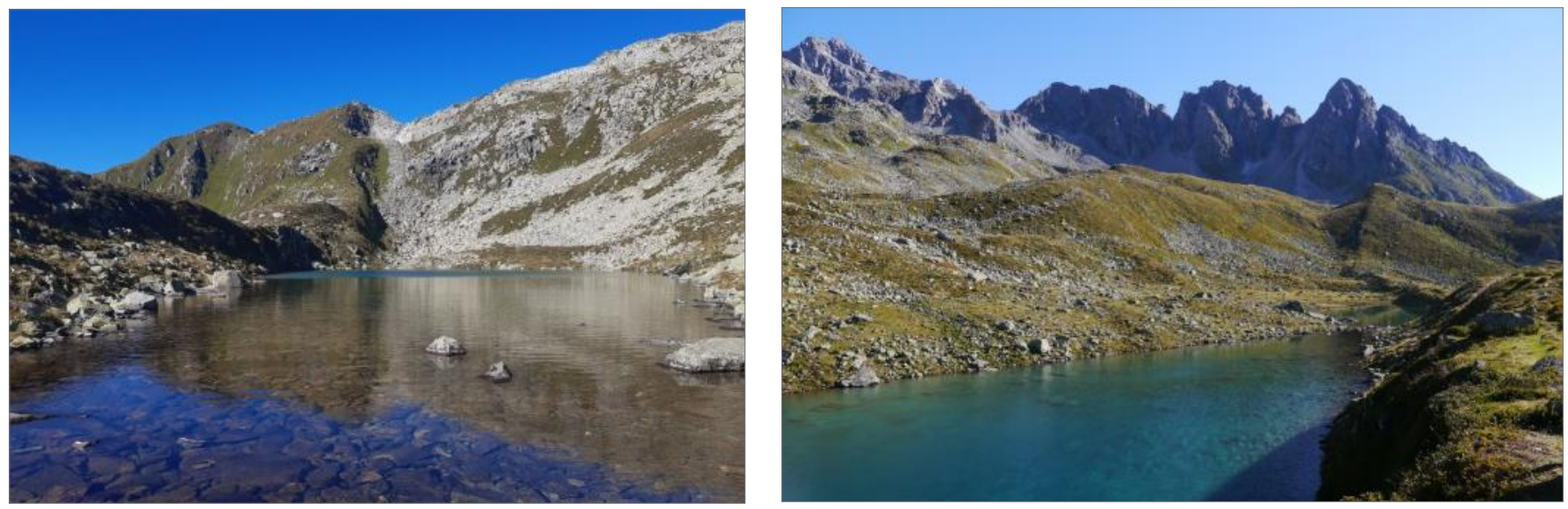

Lag Serein - the perfect lake for a (short) swim. On the right in the background: Piz Ner, $2691 \mathrm{~m}$ a.s.l.
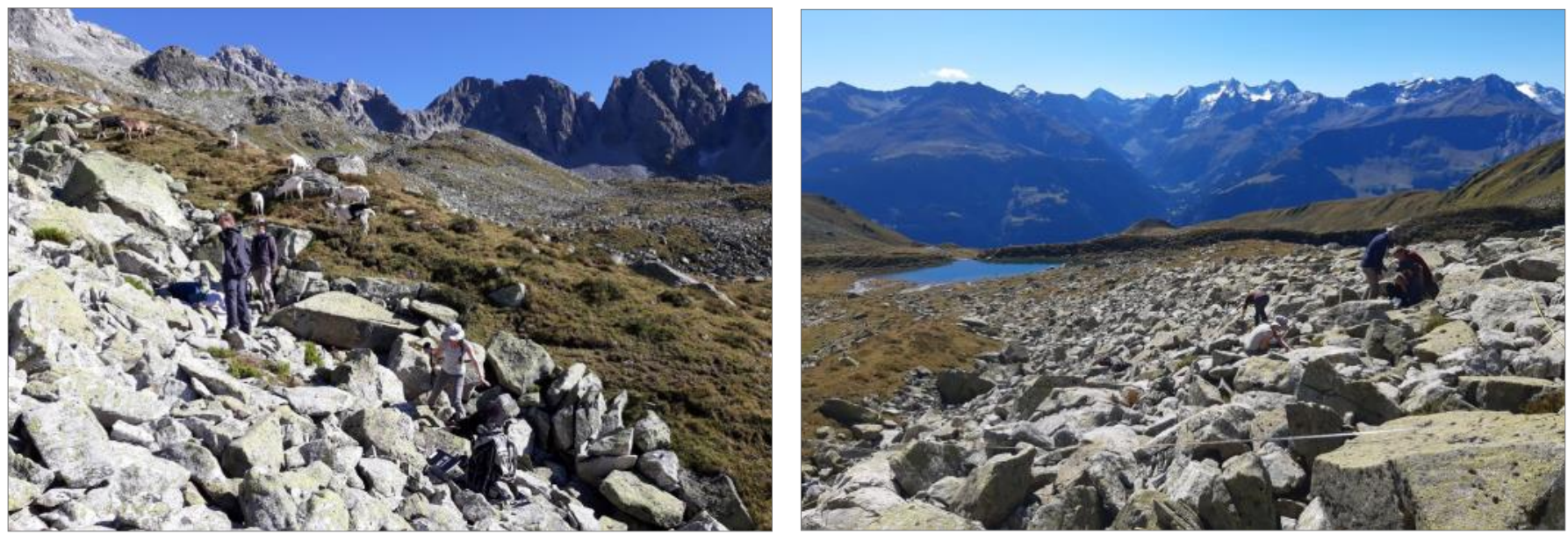

Our first plot was over scree. 

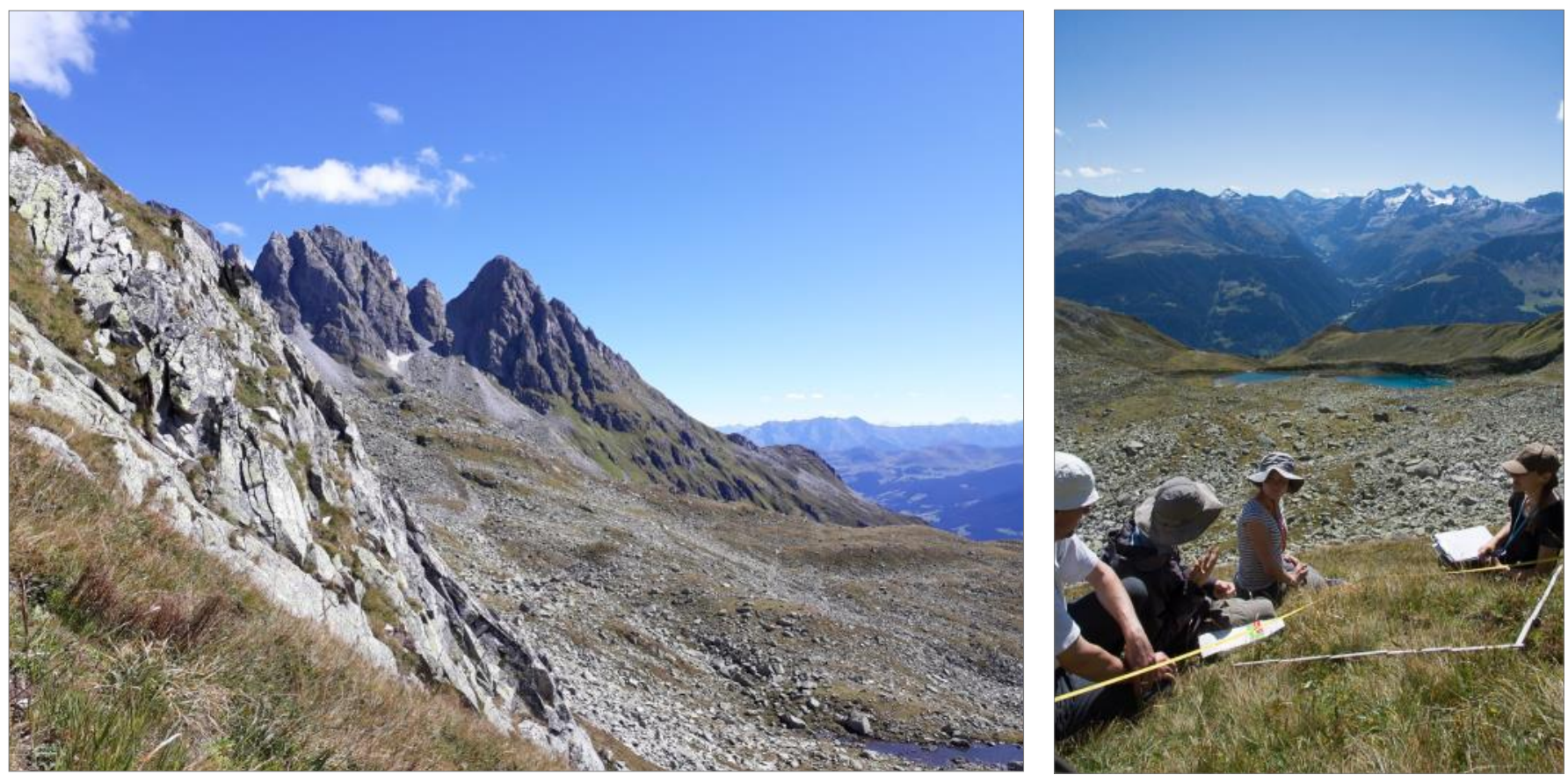

The second location in very steep unused grassland with a view of Piz Ner, $2691 \mathrm{~m}$ a.s.l. (left) and the Lepontinian Alps (right).
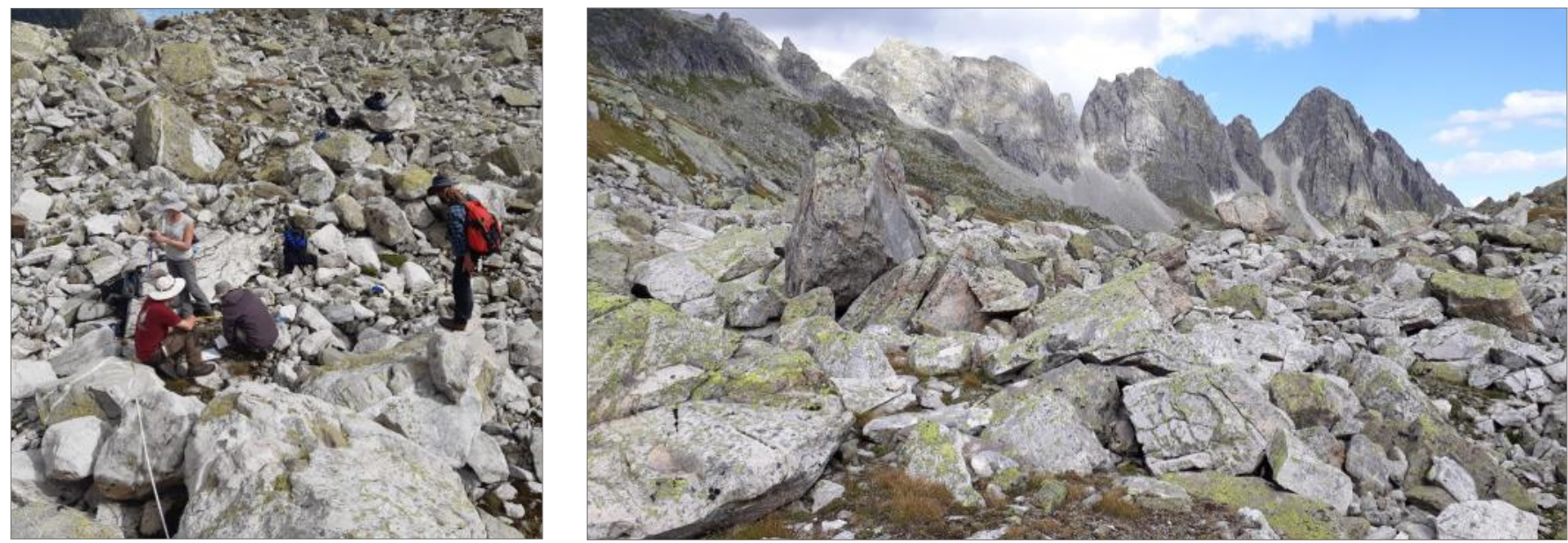

Snowbed on the slopes below Piz Posta Biala, 2499 m a.s.l., with a view of Piz Ner, 2691 m a.s.l. (right).
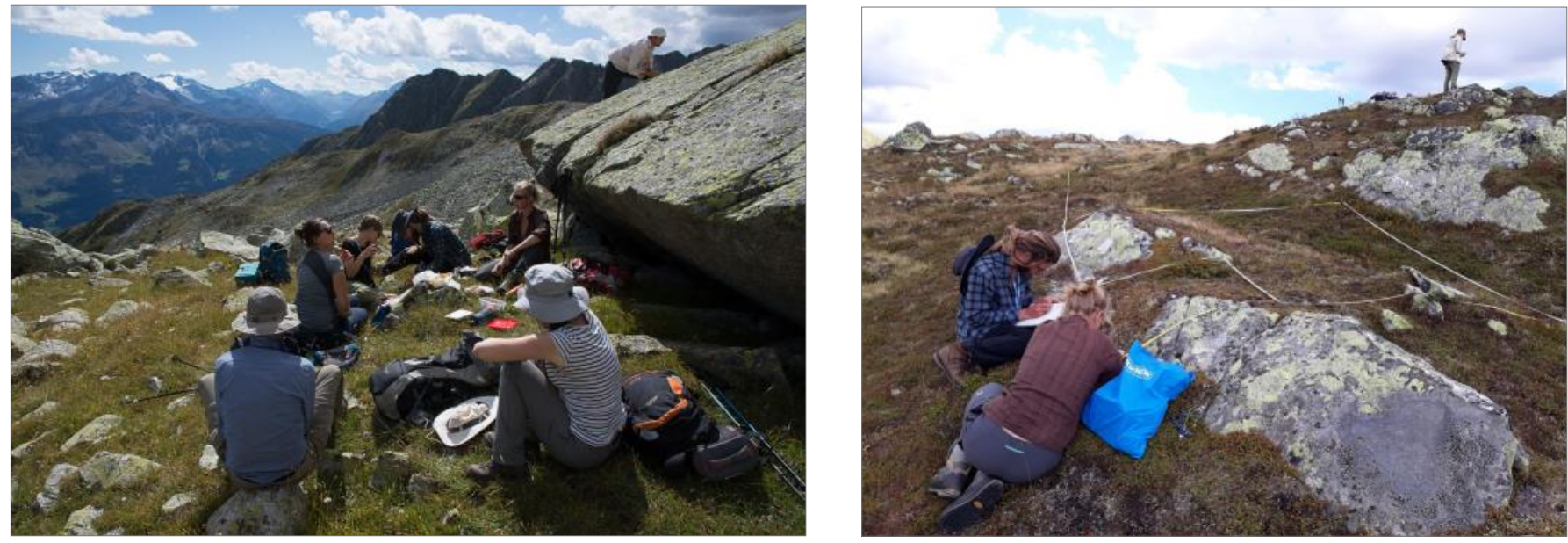

Picnic time (left) and fourth plot in a low-grown heathland (right). 


\section{Day 3 (6 September 2020)}

The third day we started with fog and one of the steepest localities during this trip. Because weather forecast had predicted rain, we decided to make plots in the vicinity of the hut. We chose a tall heathland on a steep south-facing slope and a fen as our two plots. In the afternoon a storm came, offering us time to eat calmly in the hut and to identify a lot of material, including one liverwort species new to Switzerland.
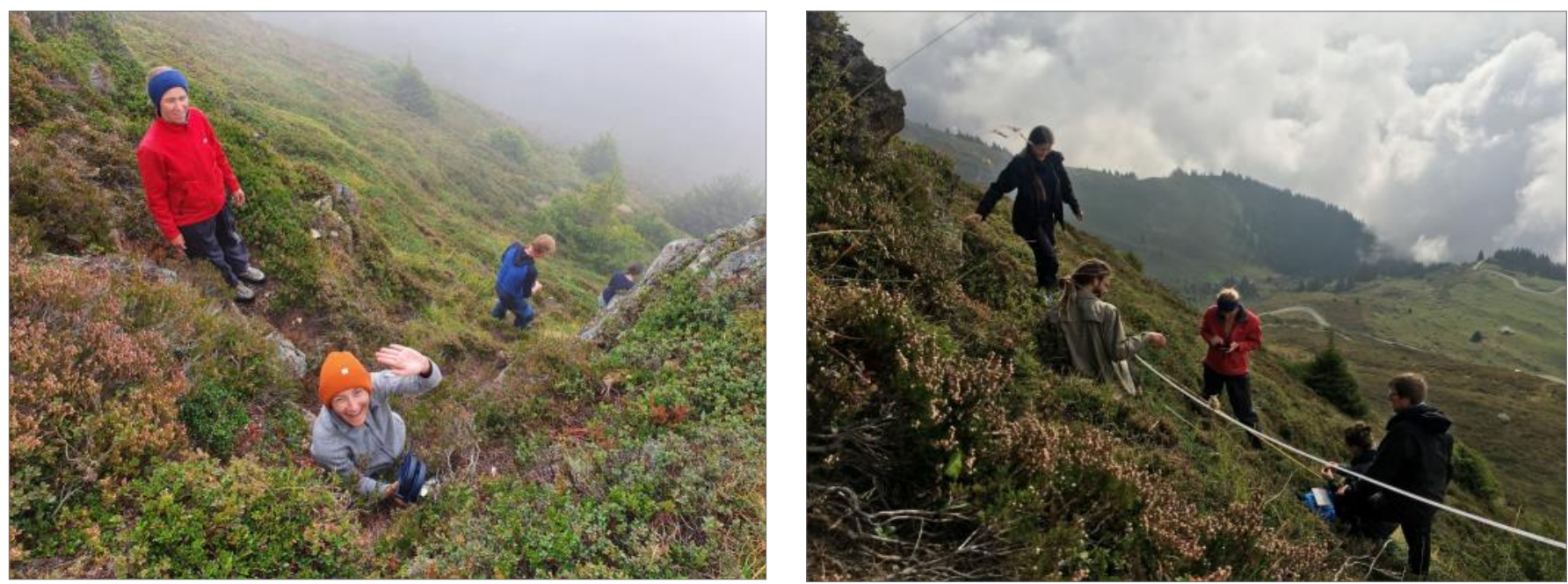

Sampling the steep plot in a tall heathland (CHA07).
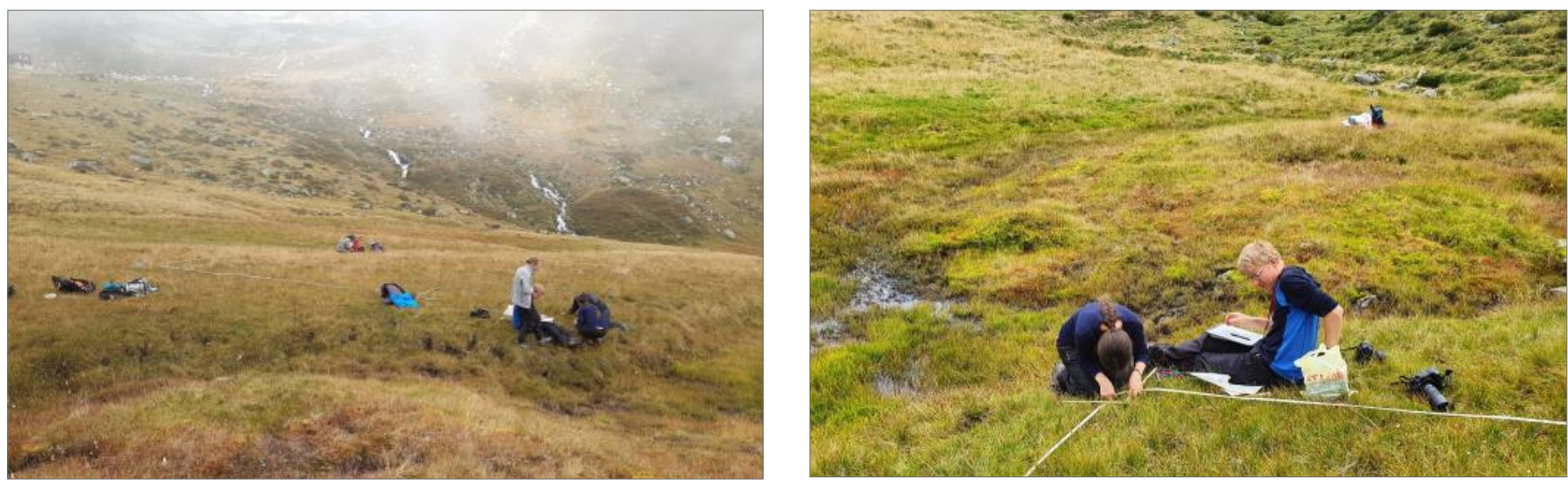

Sampling in an acidic fen (CHA08).
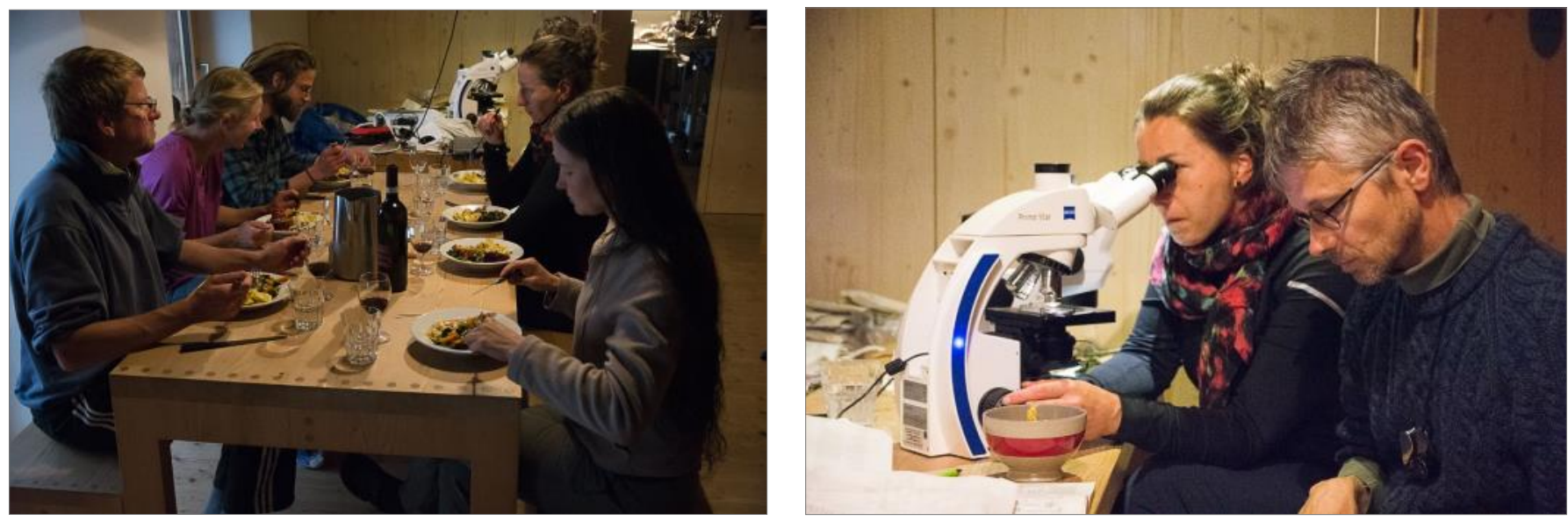

A perfect dinner and identification. 


\section{Day 4 (7 September 2020)}

On this day hardly any rain was forecasted, but essentially we stayed inside a cloud the whole day, leading to quite cool and humid conditions. We had to use all our clothes and to move a lot to survive. Nobody was thinking about swimming in a lake. A big surprise was the result of this hard day: five completed plots more than on any other day!
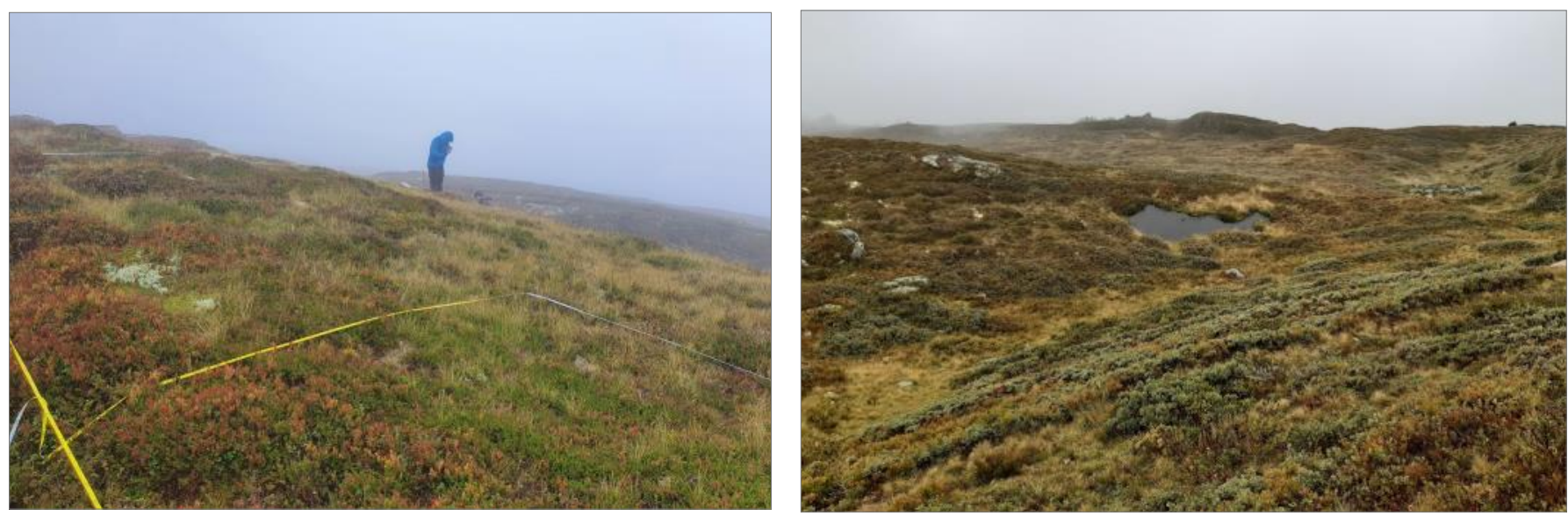

First plot of the day in a tall heathland (CHAO9).
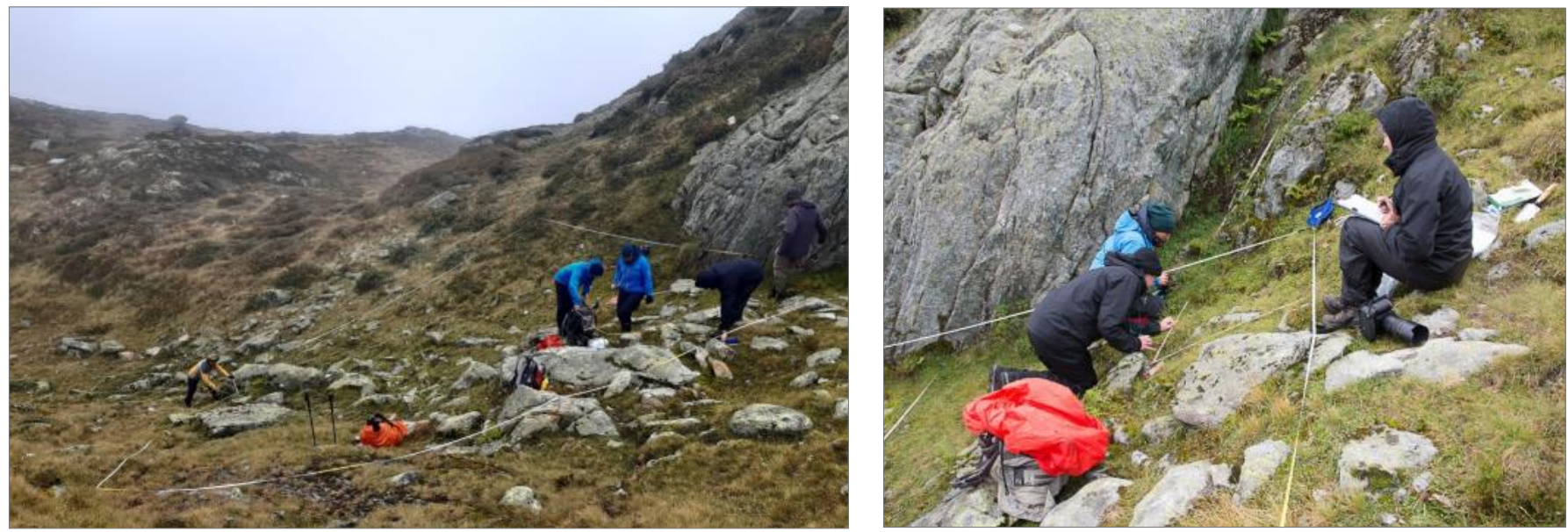

Second plot the day in a snowbed (CHA10).
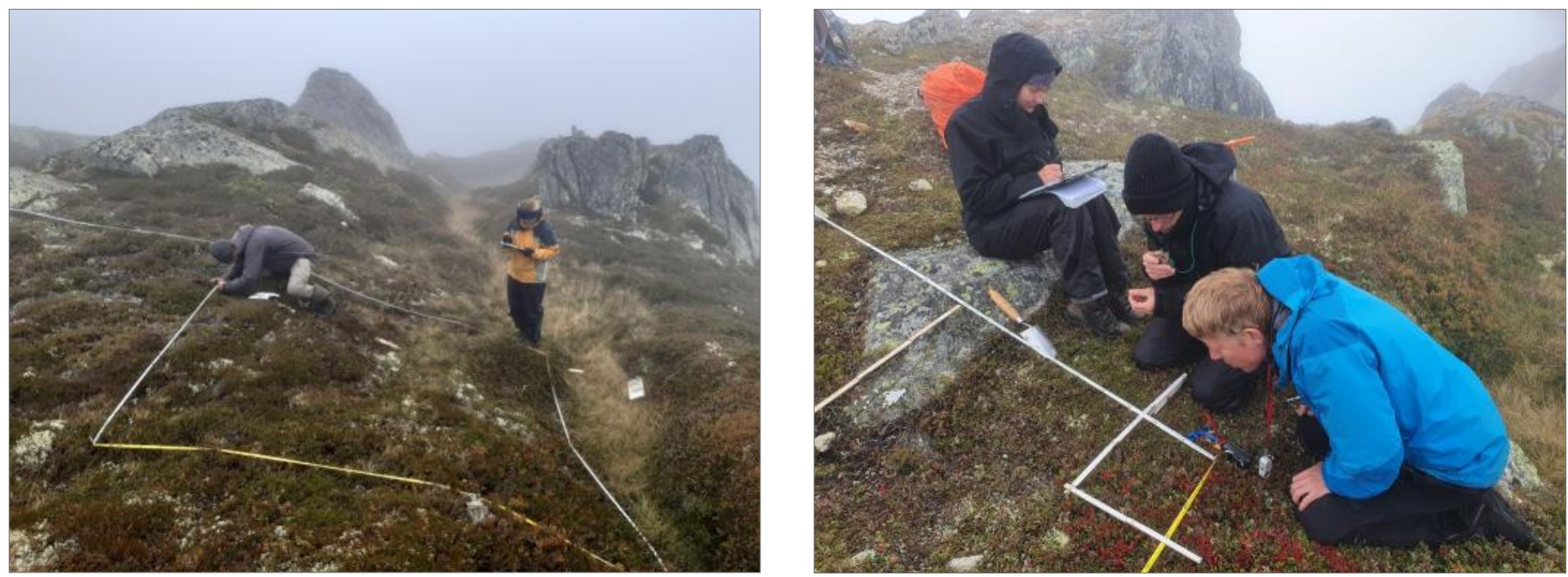

Sampling low-grown heathland at a summit below Piz Avat, at $2170 \mathrm{~m}$ a.s.I. 

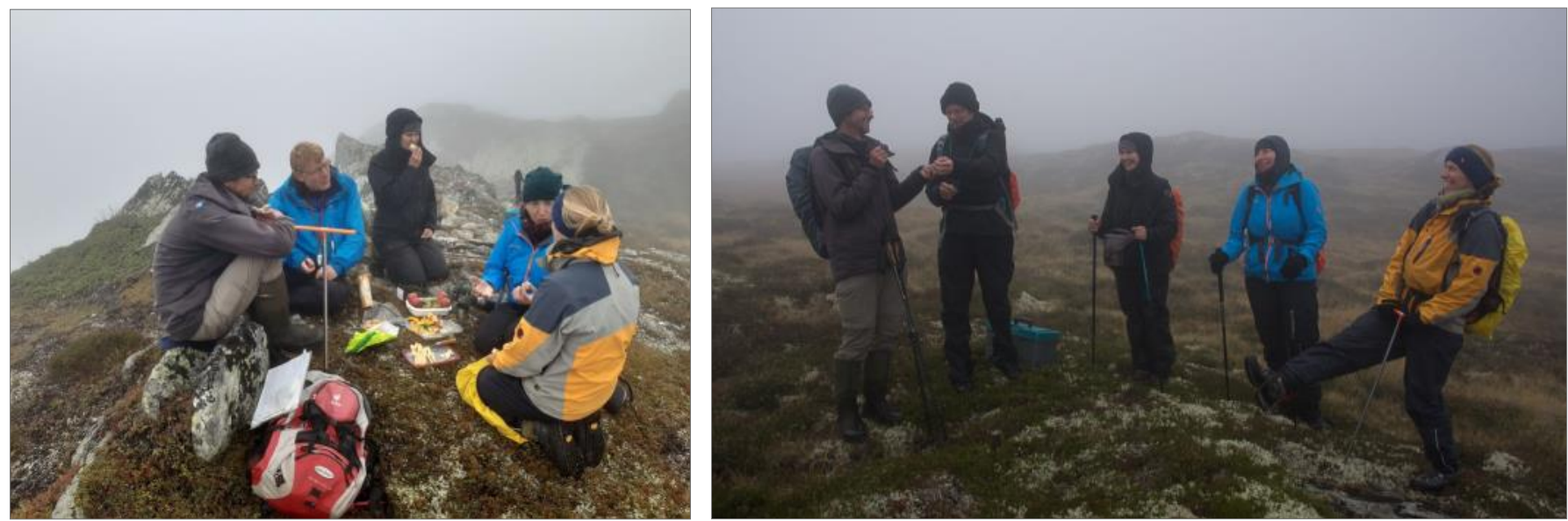

Good picnic and explaining lichens can make you happy.

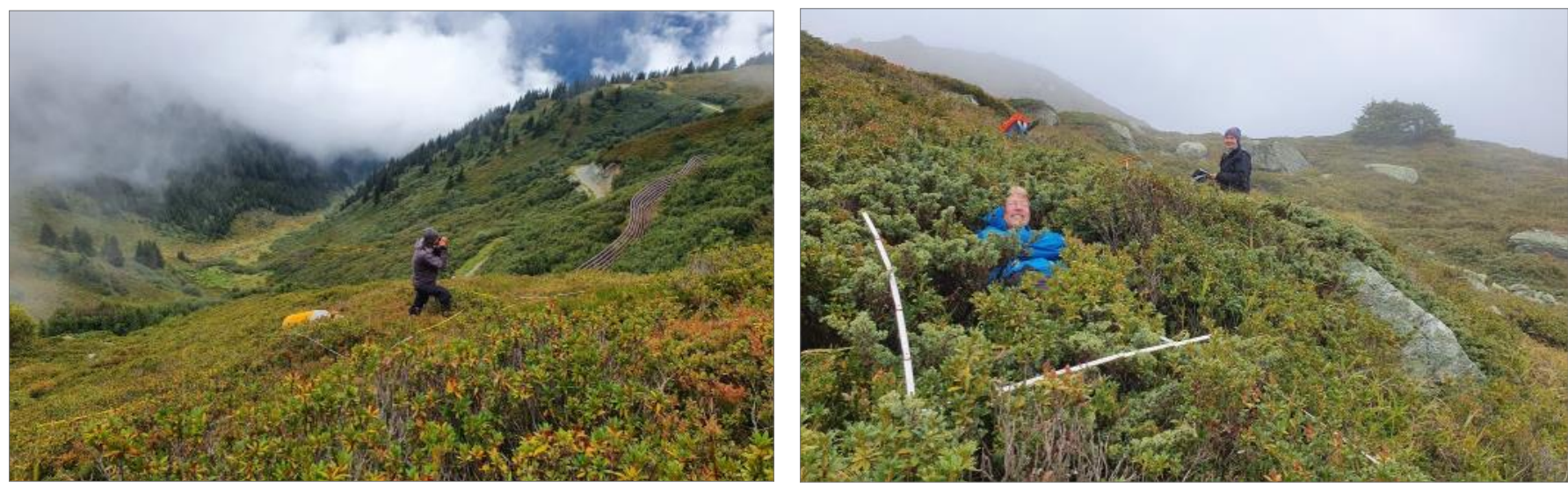

Tall heathlands with a dominance of Rhododendron ferrugineum and Juniperus communis subsp. alpina (plot CHA12).
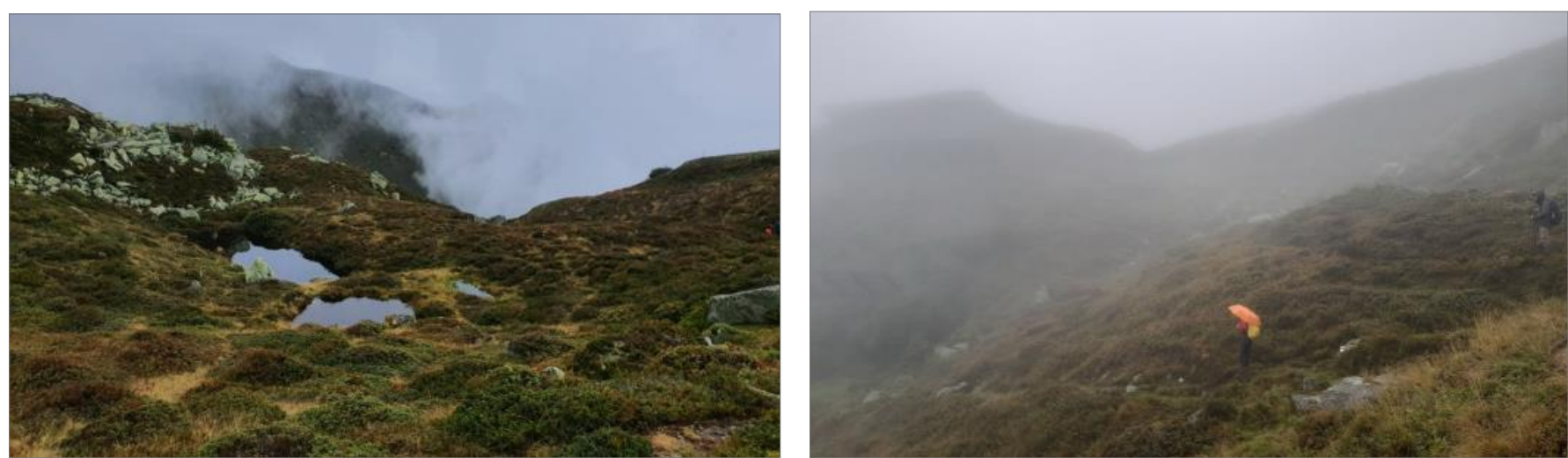

Views from the few moments when the fog lifted.
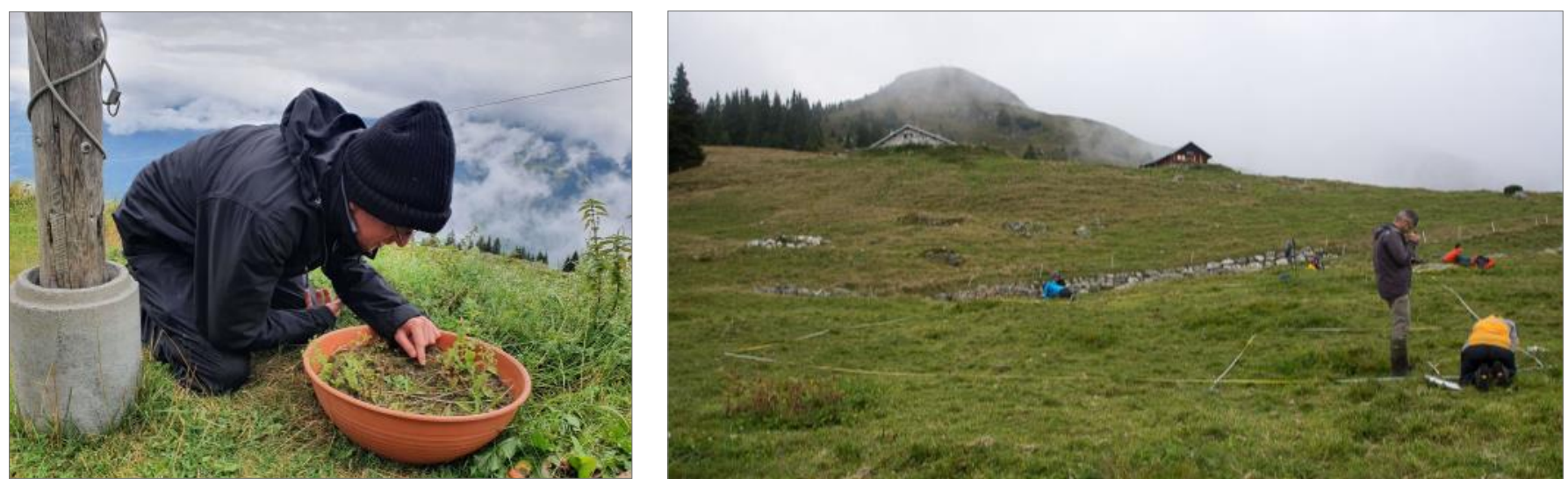

After a short break for a hot coffee and cake, we made one more plot in grazed grassland, just below the hut (right). One of us was quite eager to work despite the biting cold (left). 


\section{Day 5 (8 September 2020)}

With the fifth day, the second part of our expedition started. Unfortunately, two persons left our group: Hallie had to go to work and Timon had to continue his personal research. We left Alp Glivers and travelled from Grisons to Zermatt in Valais. We drove via two of the highest passes in Switzerland: the Oberalppass (2046 $\mathrm{m}$ a.s.l.) and Furkapass (2436 $\mathrm{m}$ a.s.l.). Zermatt welcomed us with beautiful, sunny weather. During the first afternoon, we settled into our lodgings and made three normal $\left(10 \mathrm{~m}^{2}\right)$ plots in dry grasslands in the Zmutt valley above the town.

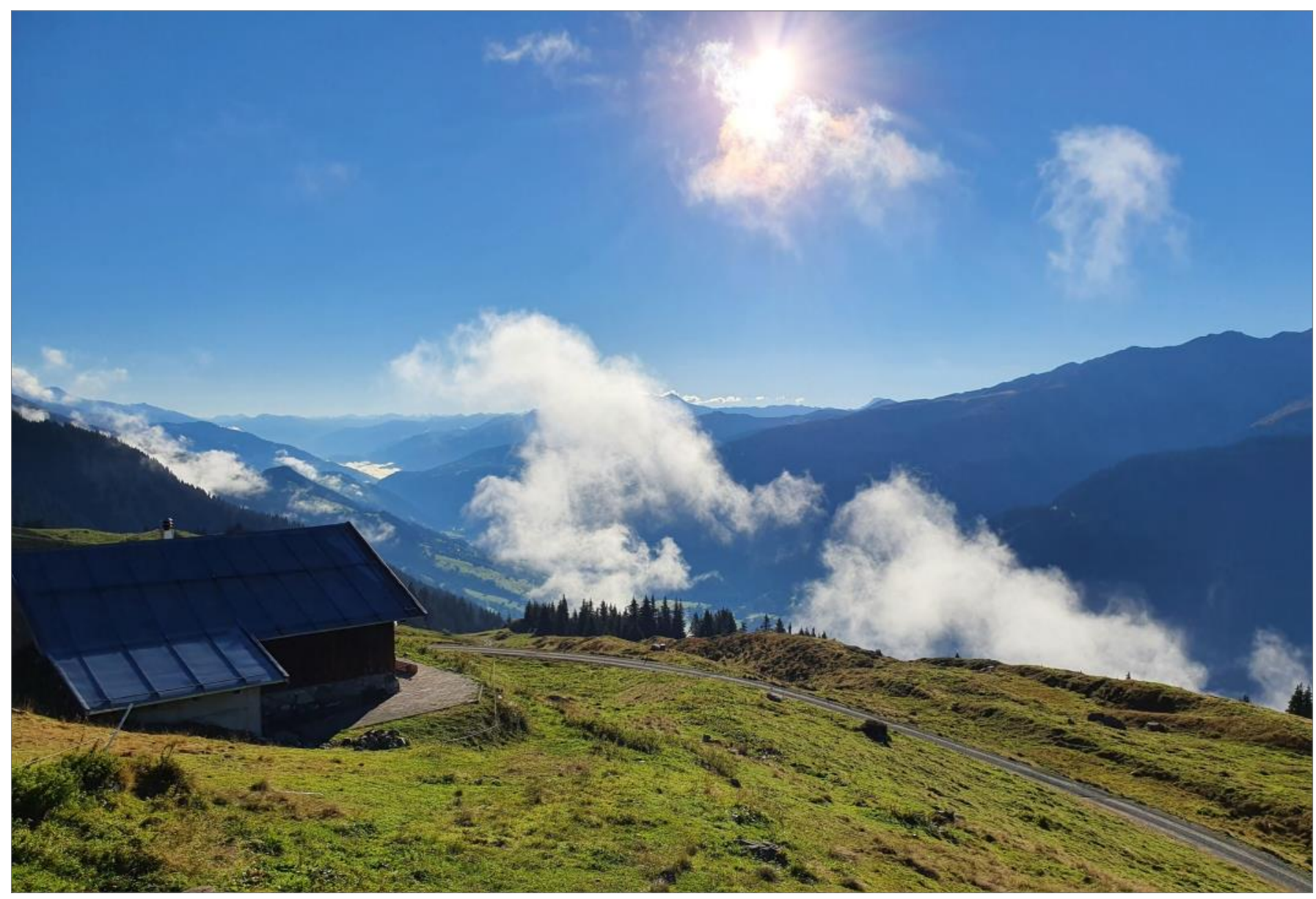

Last view from Stalla Alp Glivers (left).

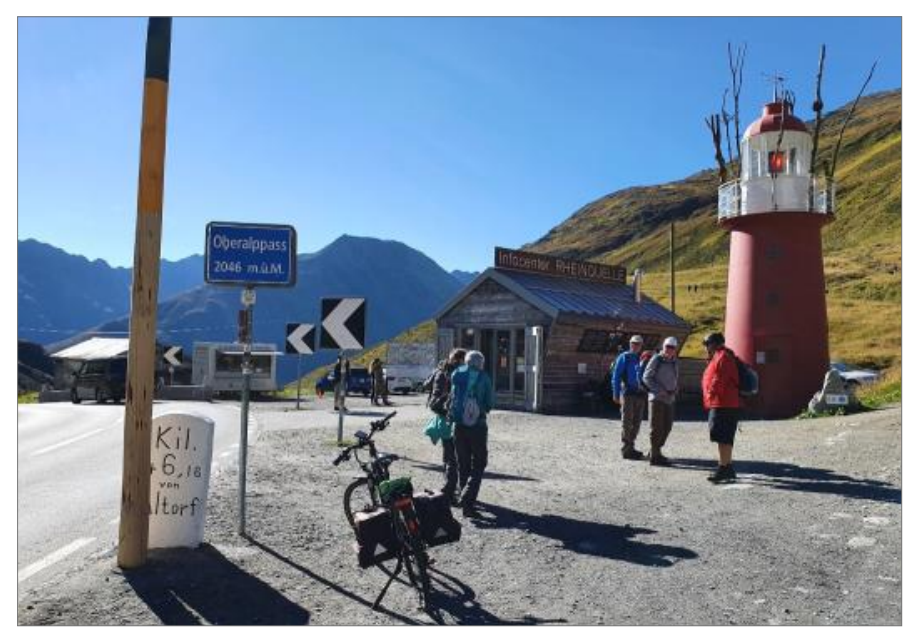

Oberalppass (2046 m a.s.l.) (left) and Furkapass (2436 m a.s.l.) (right).

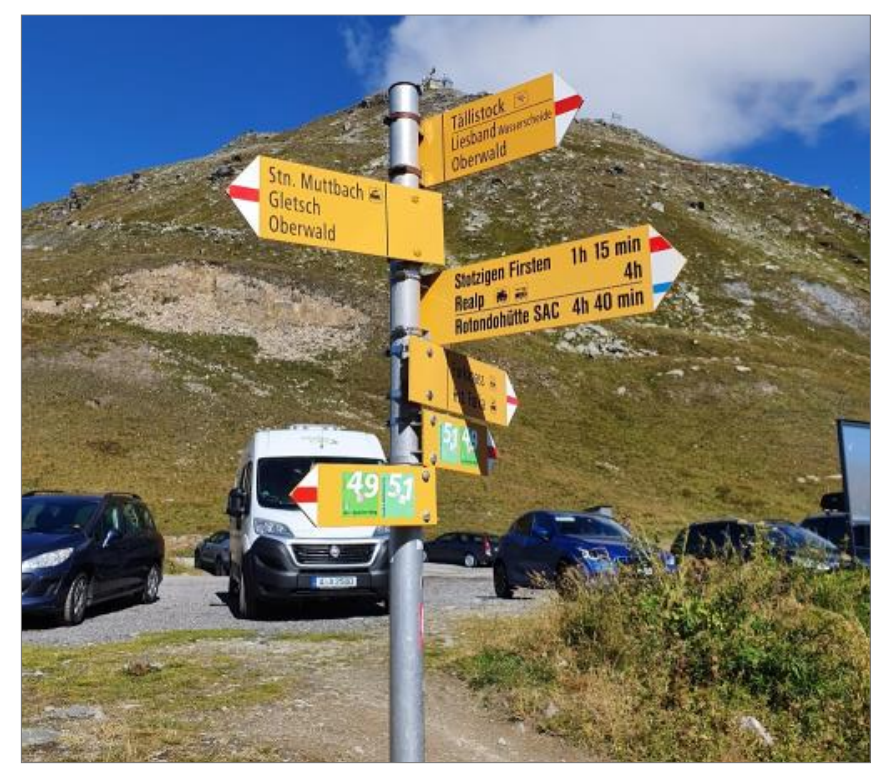



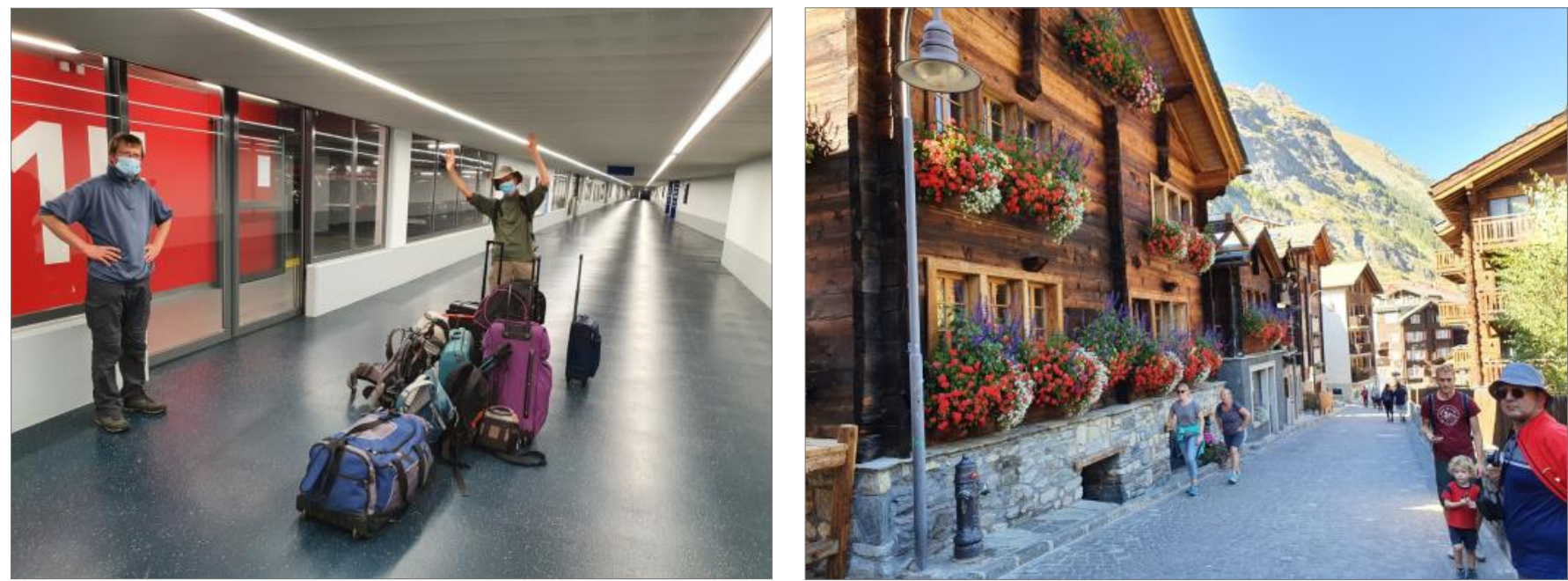

To reach Zermatt, we had to leave our cars in Täsch and travel by train. Zermatt is a town without private car transport. Due to the pandemic, Zermatt was almost empty (right).
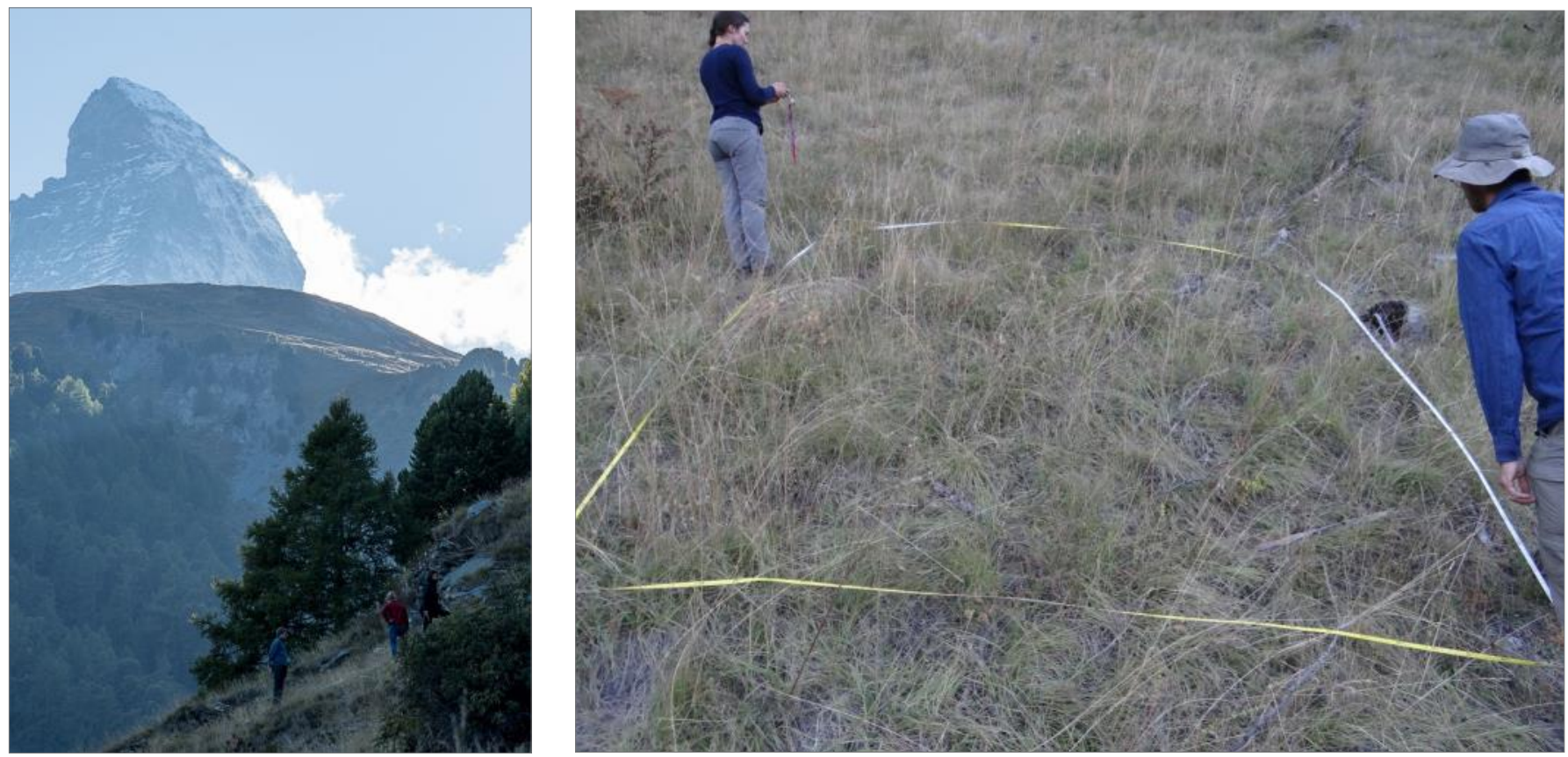

An afternoon spent sampling $10-\mathrm{m}^{2}$ plots in dry grasslands with a view of the Matterhorn (4478 $\mathrm{m}$ a.s.I.).
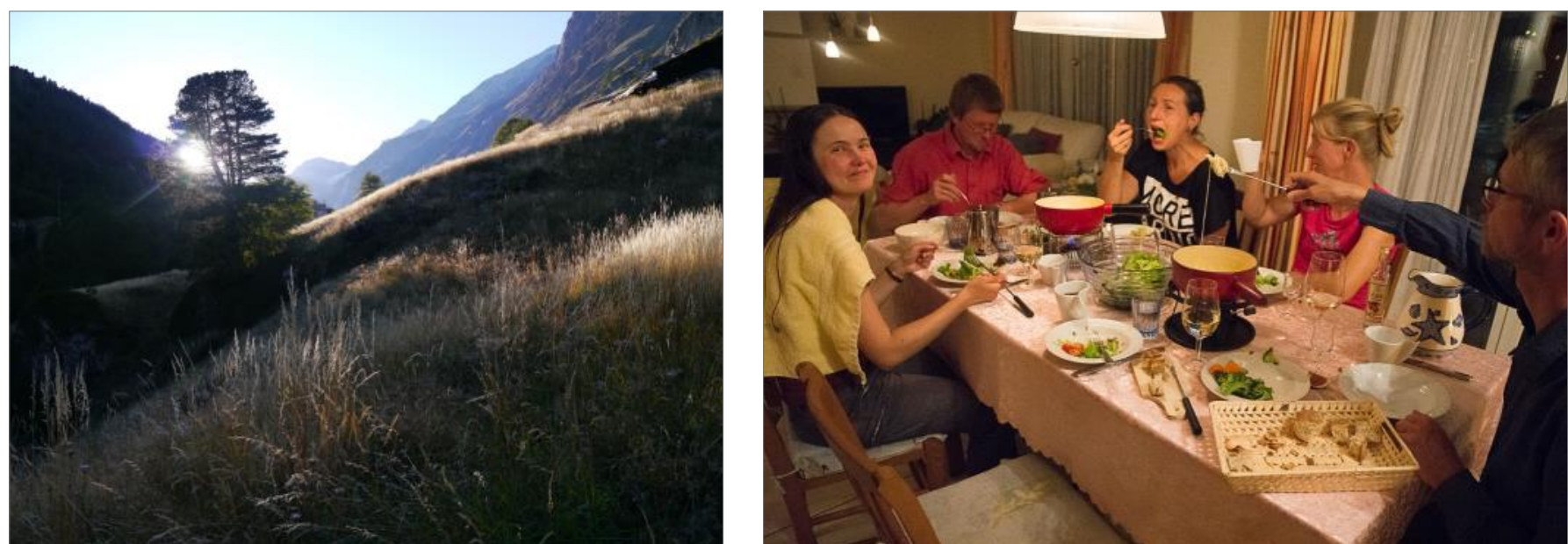

Left: evening impression from the Zmutt valley. Right: it's impossible to visit Switzerland without eating some form of melted cheese. In the evening we thus prepared cheese fondue in our rented flat. 


\section{Day 6 (9 September 2020)}

The weather was still perfect, like during summer. We hiked west of Zermatt into the Zmutt valley, enjoying plenty of views of the Matterhorn all day. Probably we took the most pictures during this day. We made three plots over base-rich grounds: one on a moraine, one on a scree and one in high mountain grassland. During the way we learned a lot, not only about plants, but also about grasshoppers. After this day we had to say goodbye our two super nice lichenologists - Christian and Patrick.
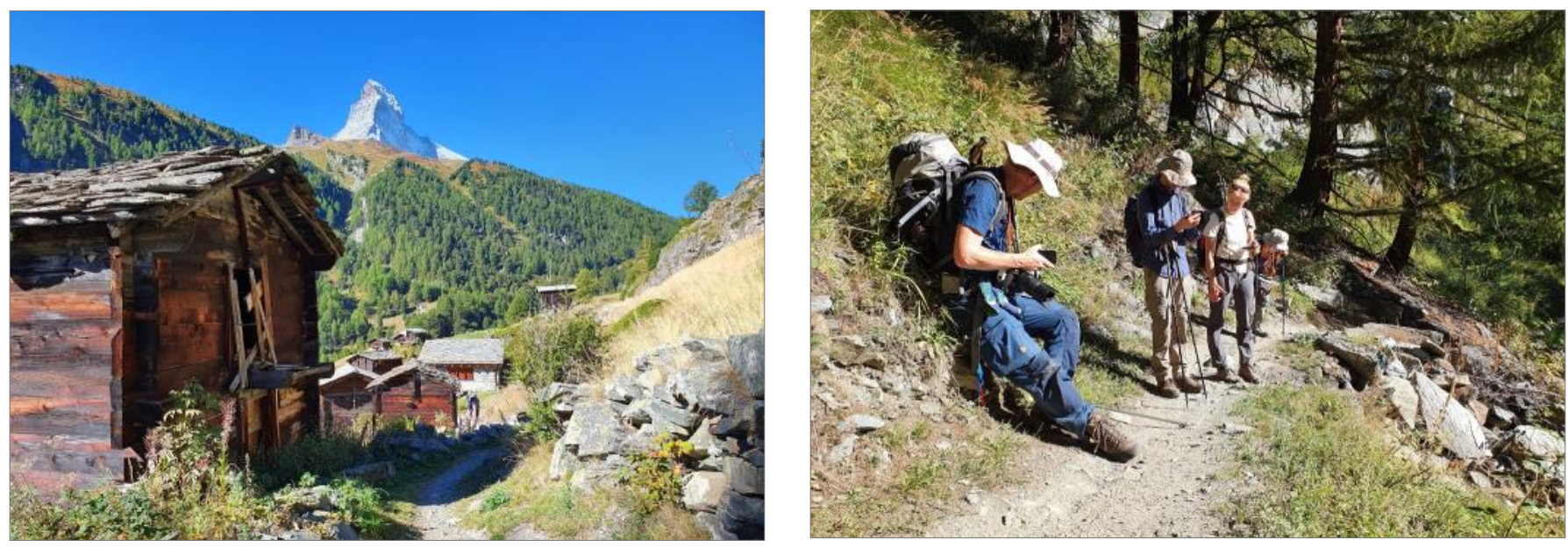

On the way to our first plot, we took the "Kulturweg" with many old, traditional houses and beautiful views.
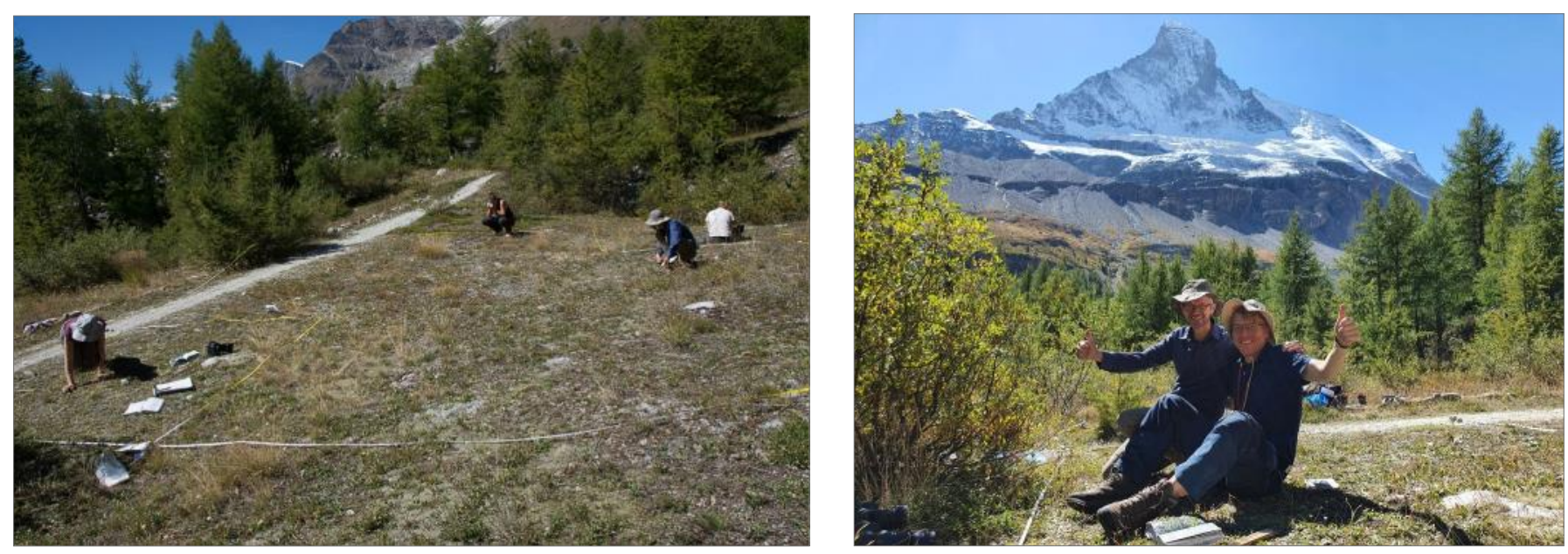

Our plot on moraine (CHA14) (left) and goodbye with Christian (right). Both of our lichenologists, Christian and Patrick, moved on for a BLAM meeting.
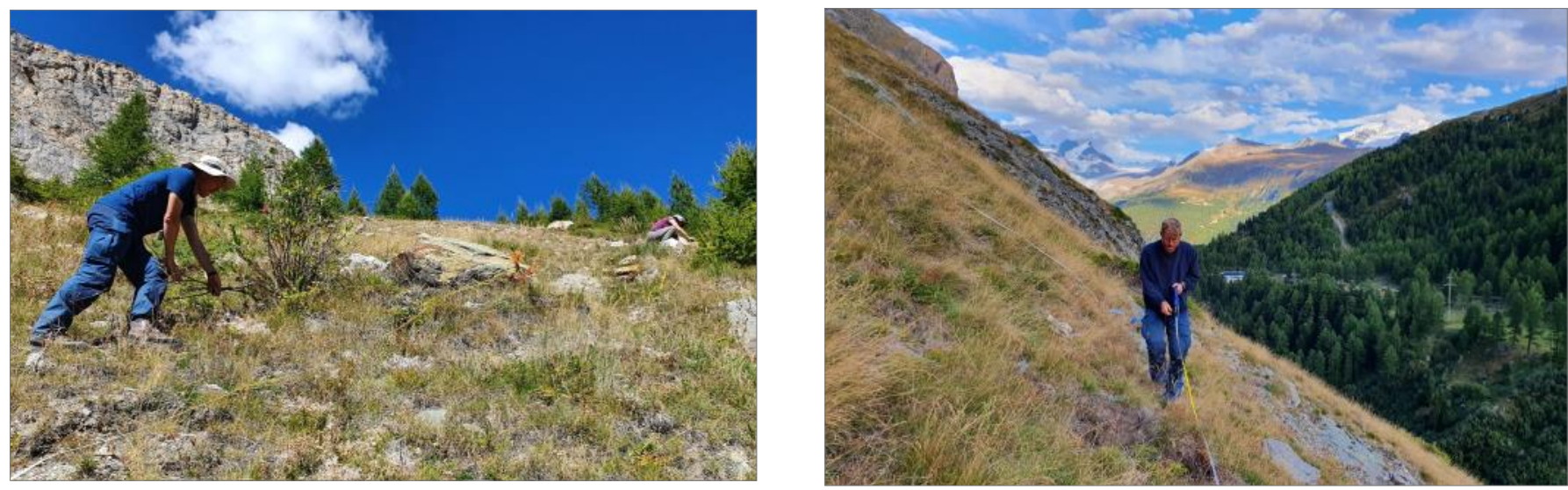

Left: second plot on a scree (CHA15). Right: third plot in a grassland (CHA16). 
Day 7 (10 September 2020)

The last day in Zermatt welcomed us with clouds and cold. We decided to take the train to Gornergrat and probably made the highest complete EDGG Biodiversity Plots in the European Alps so far. It was difficult to concentrate on our work with such beautiful views! At the end of this day, we travelled back to Wädenswil.
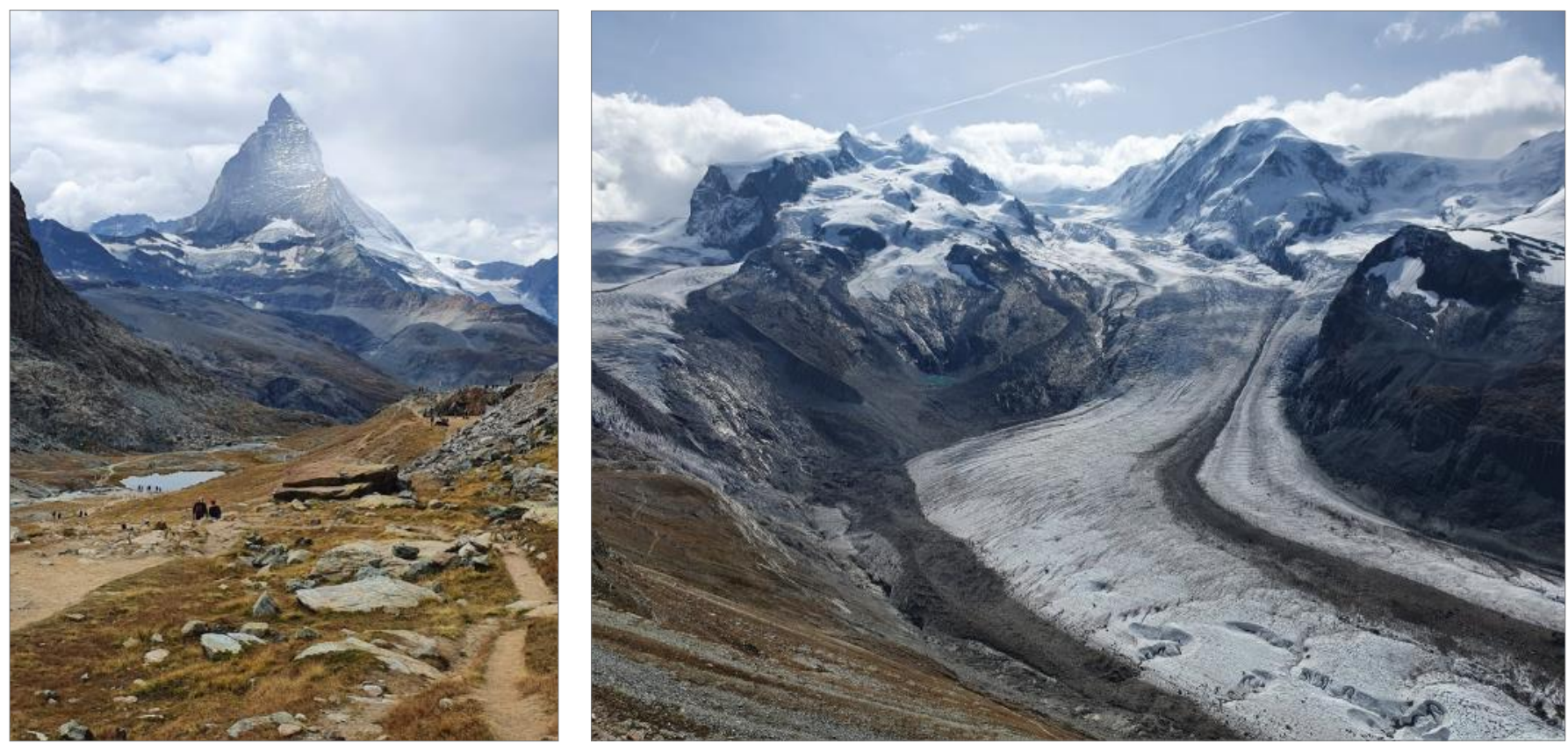

The surroundings of our research plots were noble today. Left: Toblerone, oops sorry - Matternhorn, $4478 \mathrm{~m}$ a.s.l. Right: Dufourspitze, $4637 \mathrm{~m}$ a.s.l., in the Monte Rosa Massif, the highest mountain of Switzerland.
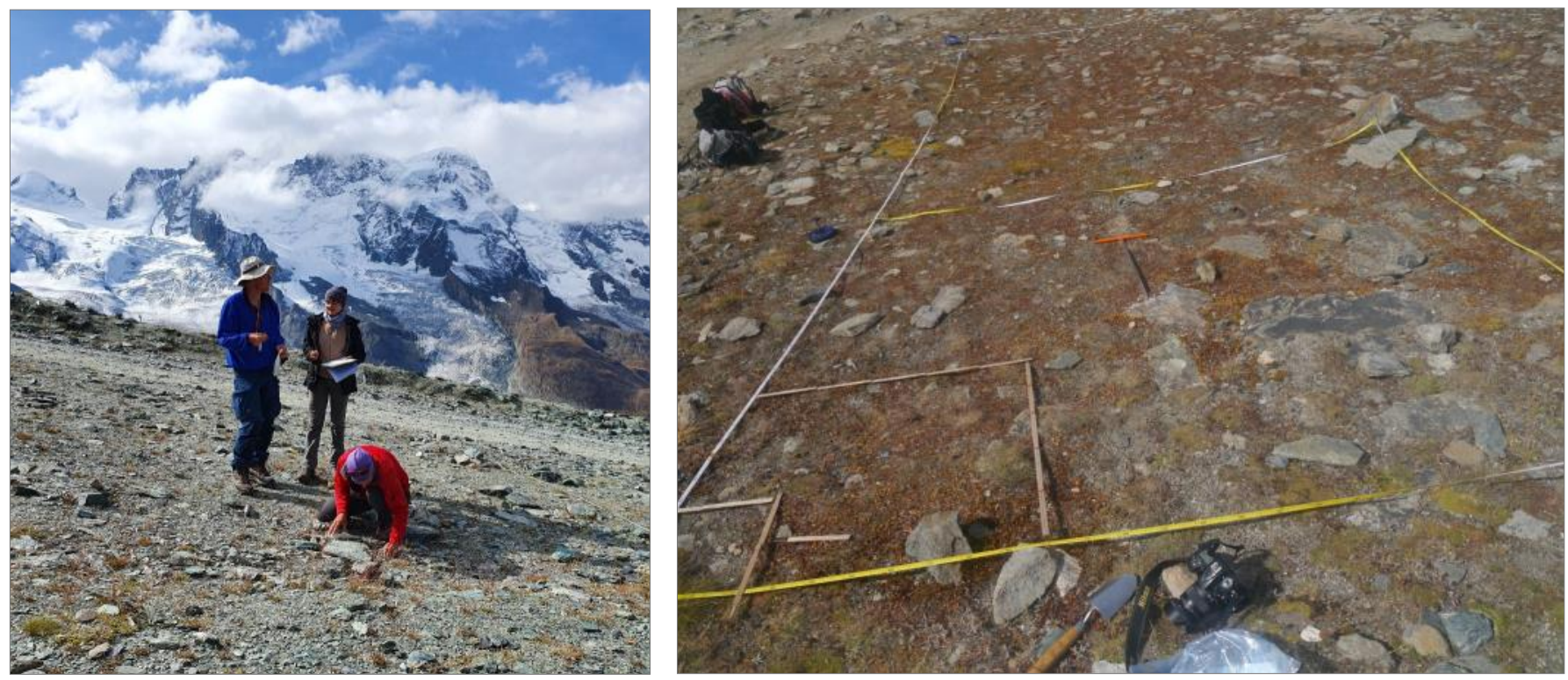

The highest plot from the expedition, $3084 \mathrm{~m}$ a.s.l., on a scree (CHA17) and the second highest in a snowbed at around $3000 \mathrm{~m}$ a.s.l. (CHA18) (right). 

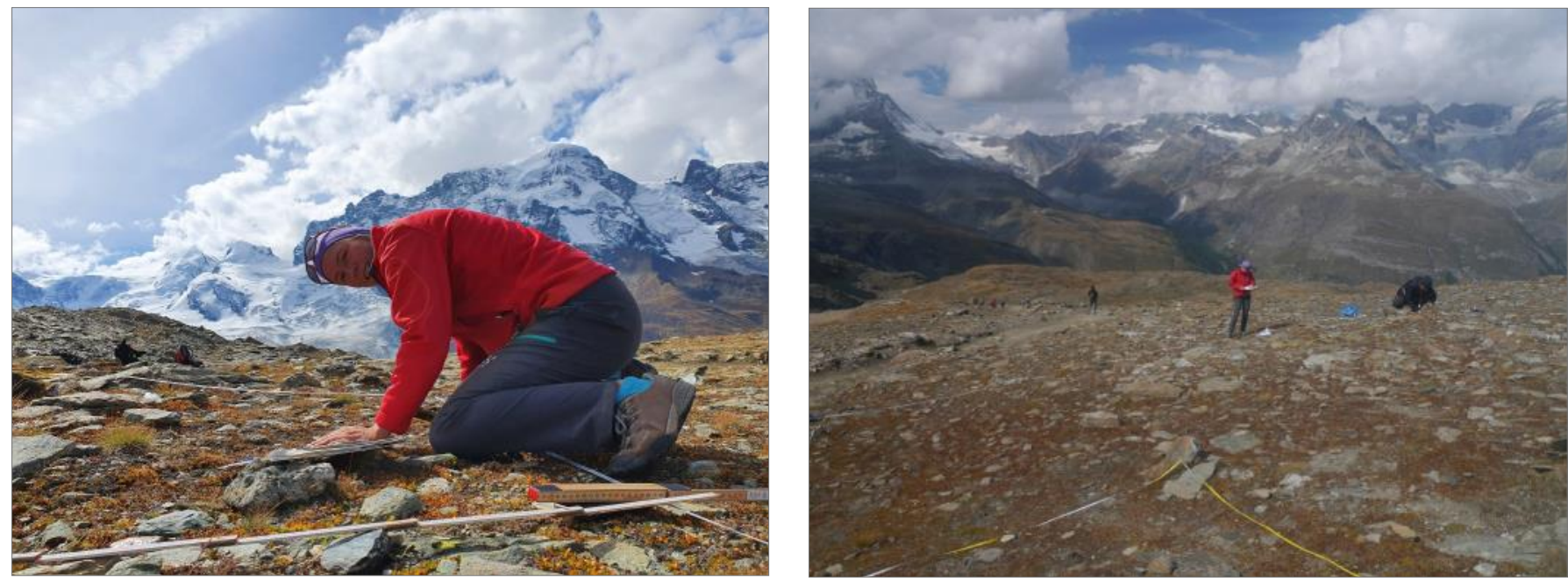

While we were working in the snowbed plot, many people asked Susanne what we were doing, and she answered in three languages! She is the best!
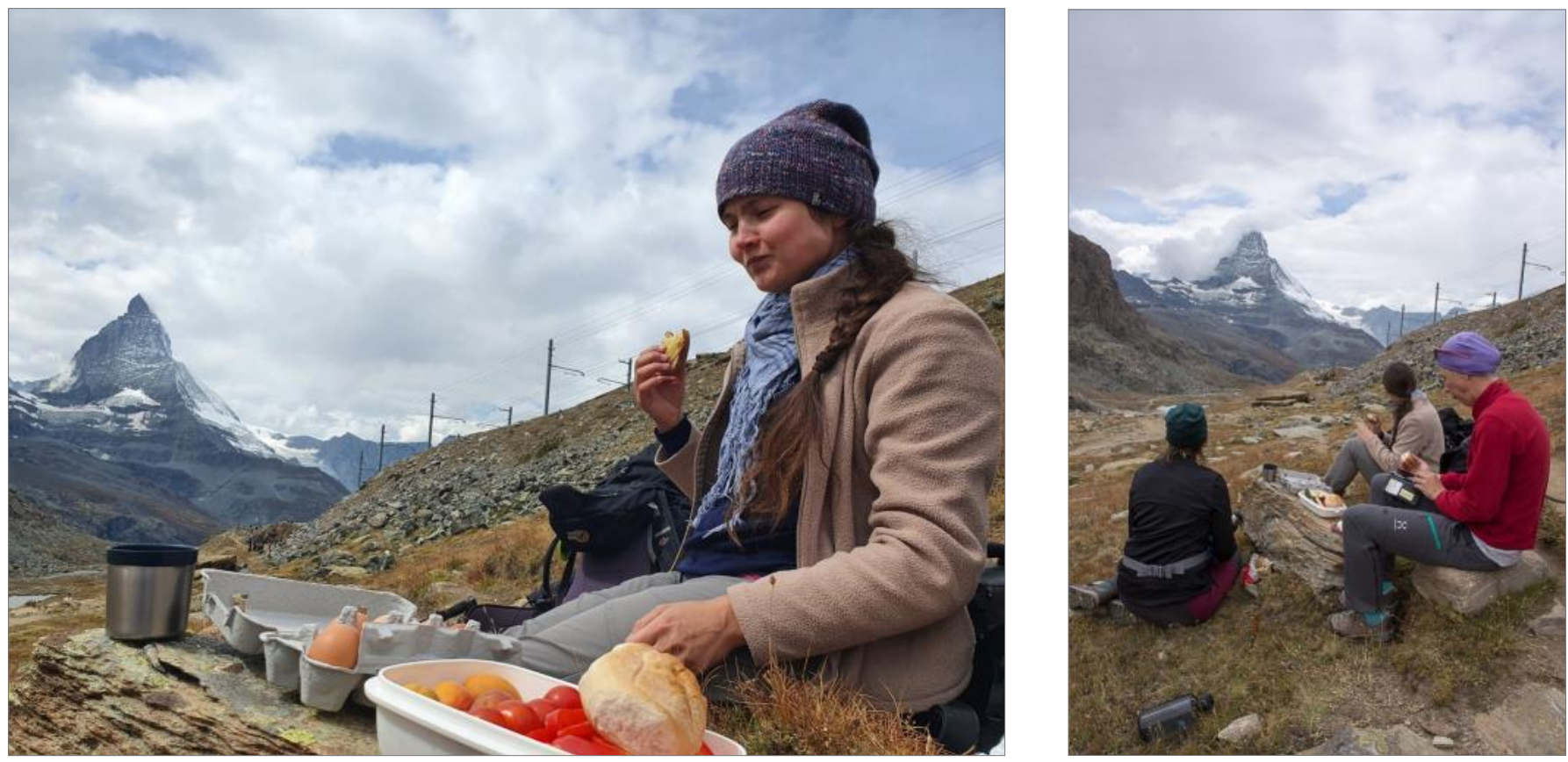

No matter how beautiful the view, you still need to eat! Picnic before the third plot.

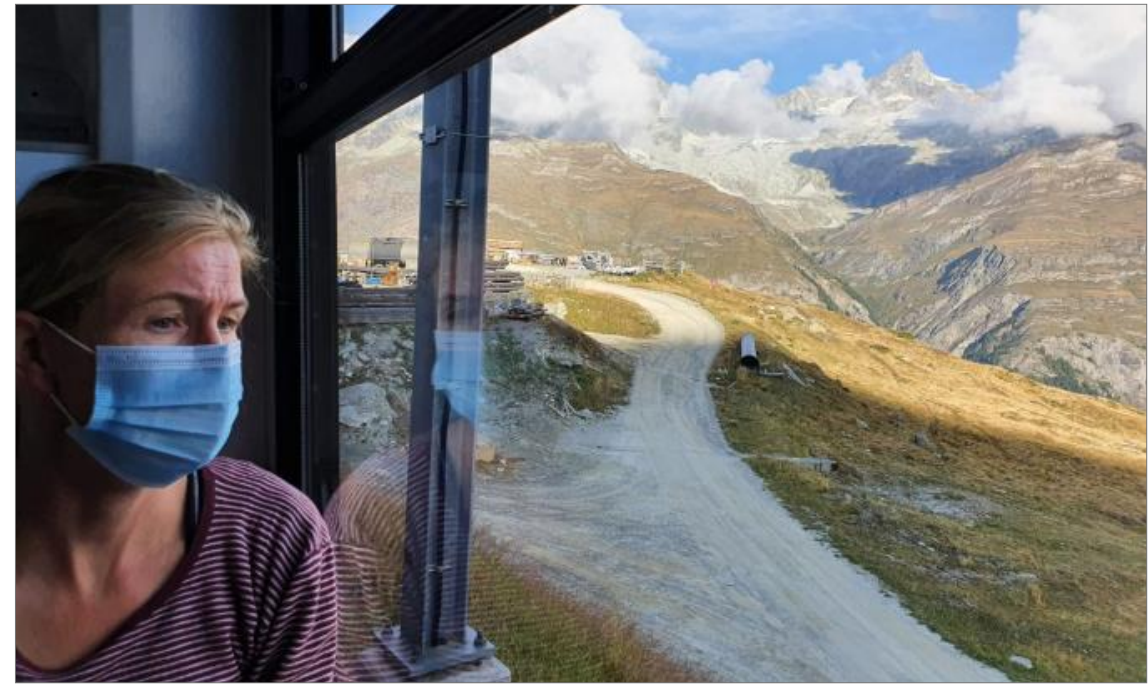

Way back with obligatory masks and later a small disinfection.

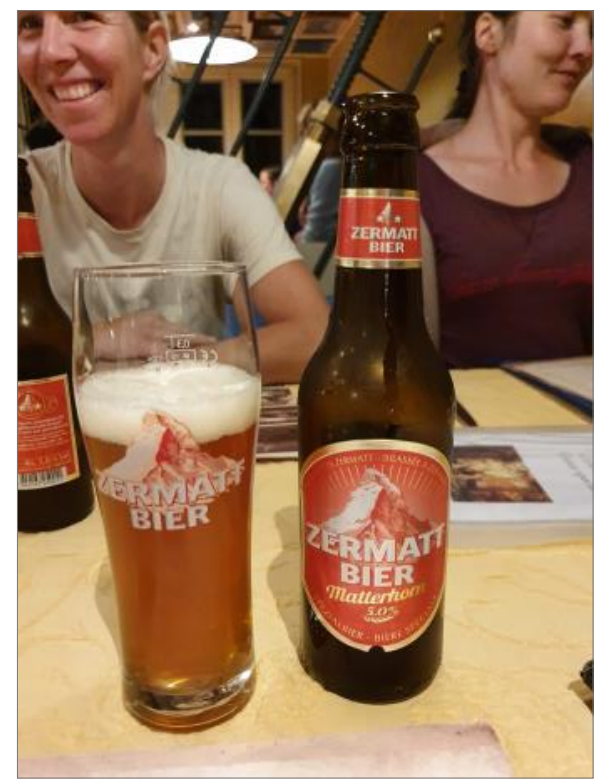


Day 8 (12 September 2020)

On this and the following two days we started from Wädenswil as base camp to the Glarus Mts., a high alpine range that can be reached by public transportation. This day, Jinghui, Jürgen's Chinese postdoc, joined the small team of Iwona and Jürgen. We sampled at Gumen above Braunwald, which we could reach, by taking two cable cars, without much walking. Only our plot sampling took too long so that for the way back, we had to replace the upper cable car by hiking as it was already closed.
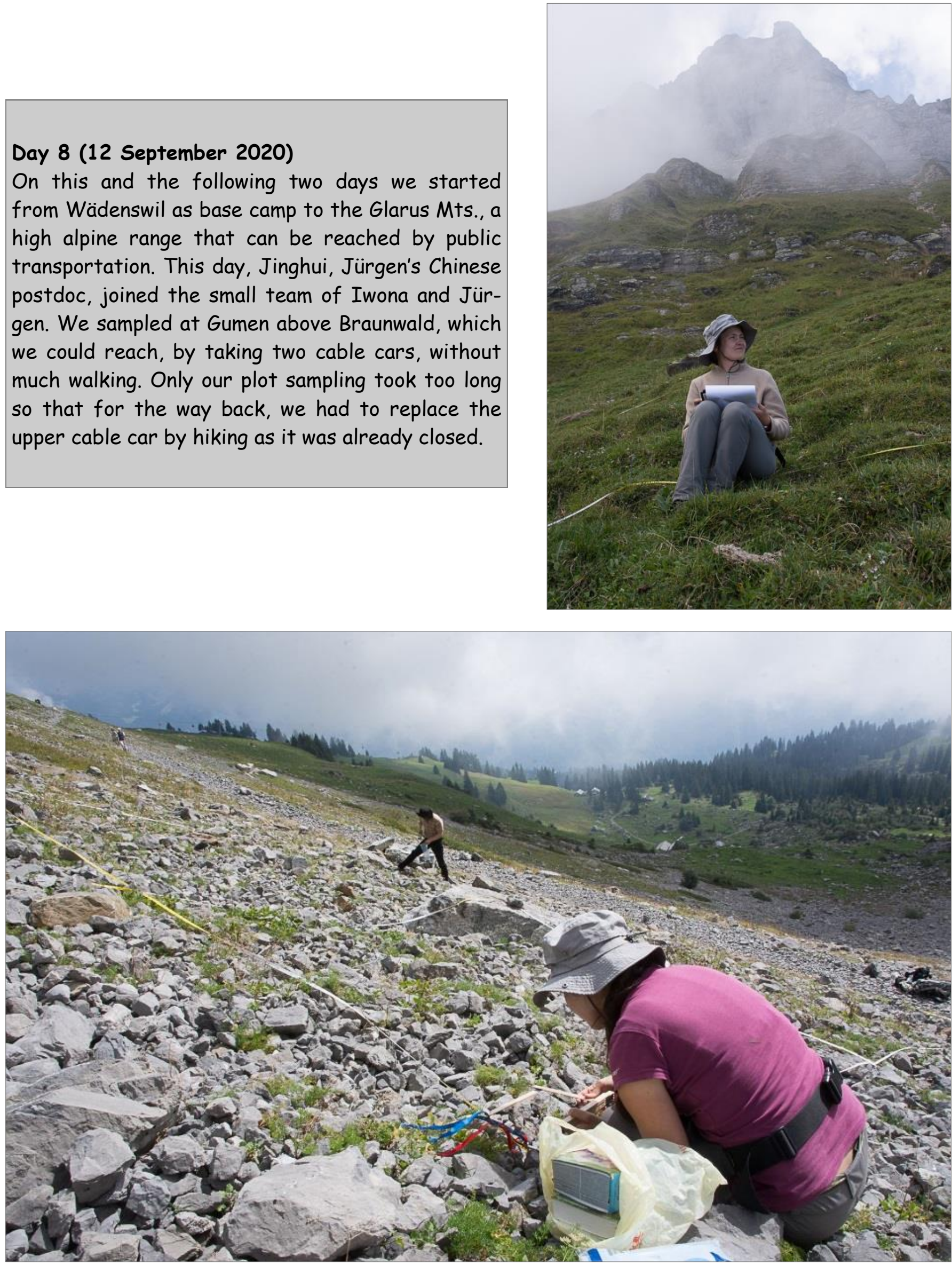

The two plots of the day, left a limestone scree (despite it looks rather empty, it still contained 27 species) (CHA20), right a limestone grassland (CHA21). 


\section{Day 9 (13 September 2020)}

We departed from Wädenswil and drove directly to the Klausenpass, $1952 \mathrm{~m}$ a.s.l. There, we left our car and hiked up the moraine of the glacier below Mt. Clariden. On this recent moraine, we could observe and record different vegetation types: moraine, snowbed and low-grown heathland. The fragments of the glacier falling into the lake were very photogenic.
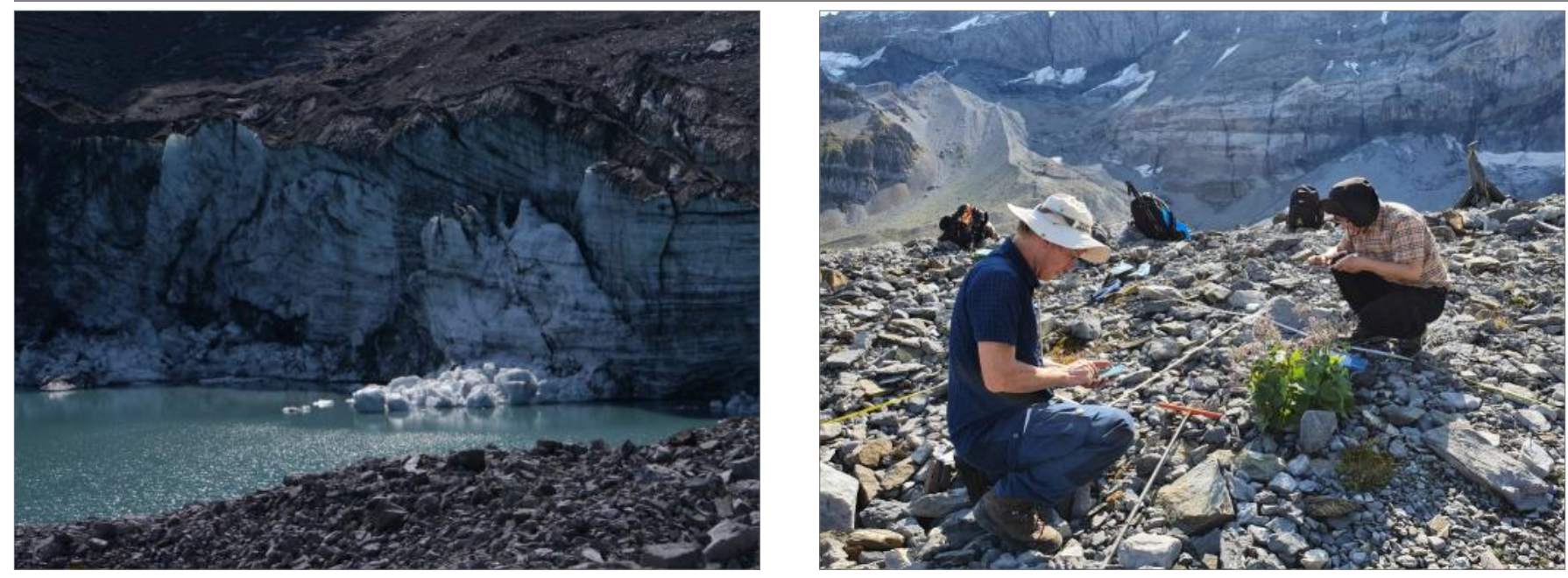

Left: the glacier below Mt. Clariden. Right: sampling a moraine plot CHA22.
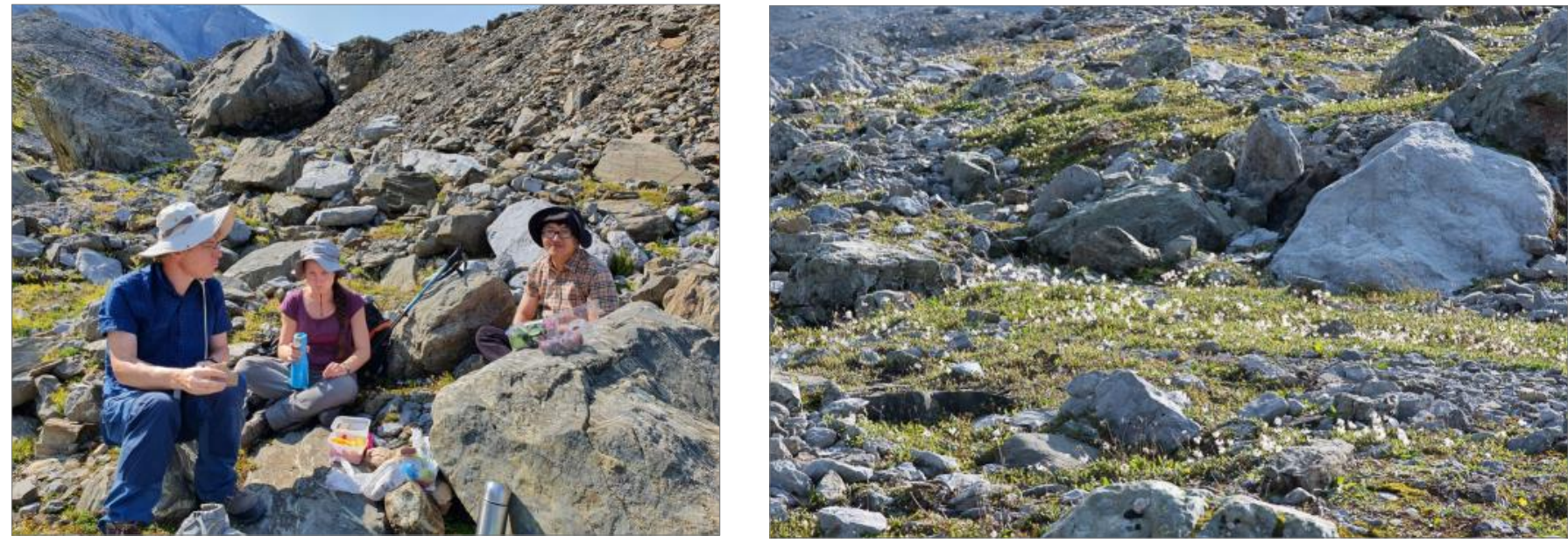

Our picnic in the snowbed plot (CHA23) and the last plot of the day in a Dryas octopetala heath (CHA24).
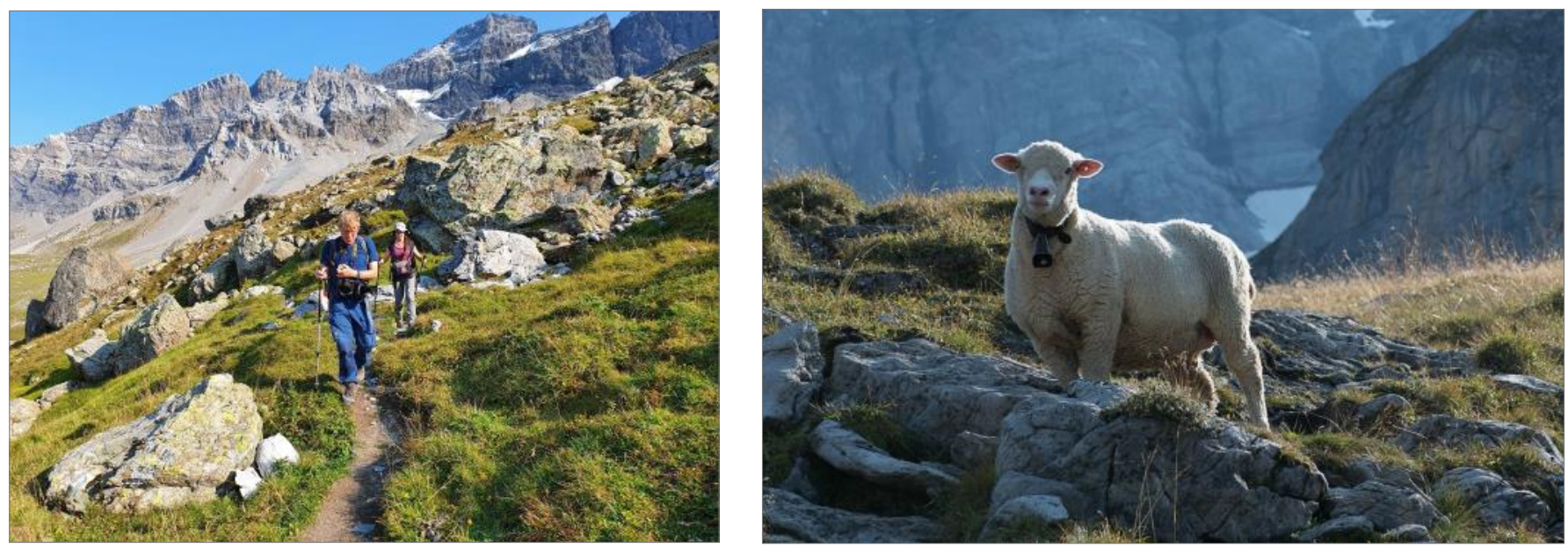

Our way back... 


\section{Day 10 (14 September 2020)}

On our last day, we again started from Wädenswil and went to Urnerboden, where we took a cable car to the Fisetenpass, $2036 \mathrm{~m}$ a.s.l. We spent quite some time walking along the ridge, searching for a limestone grassland plot that we could sample without risking our lives (because of the very steep slopes).
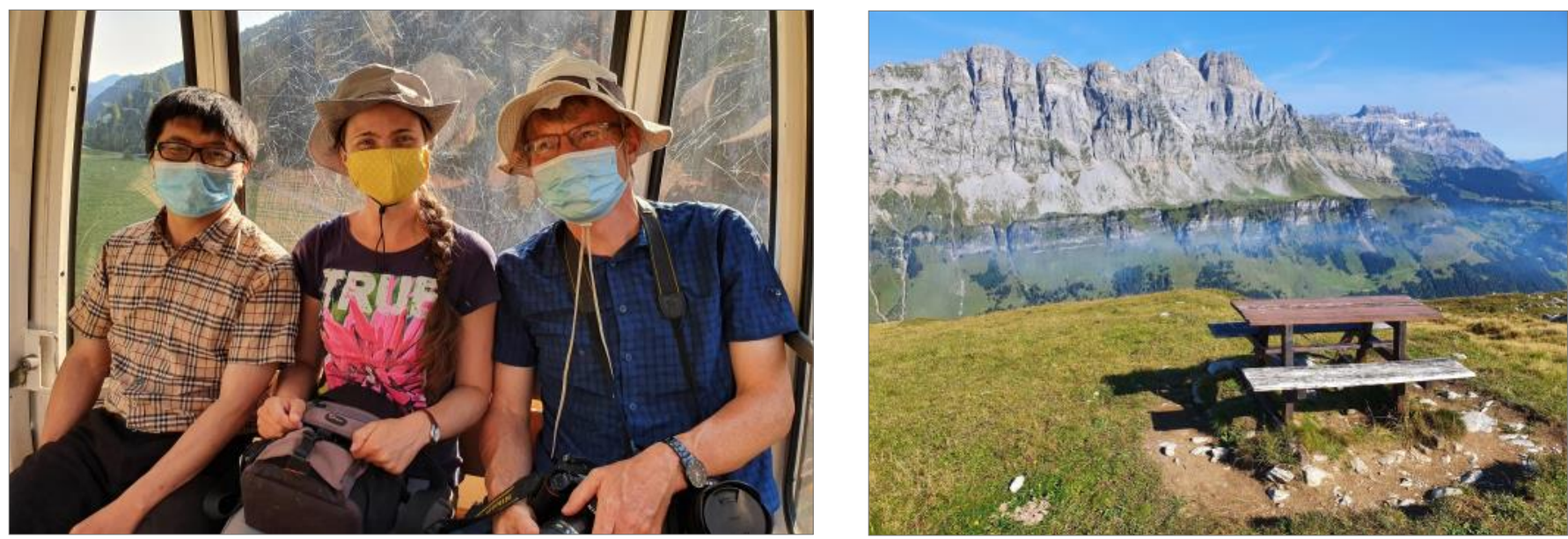

In the cable car (left) and on the way to the "ideal" plot.
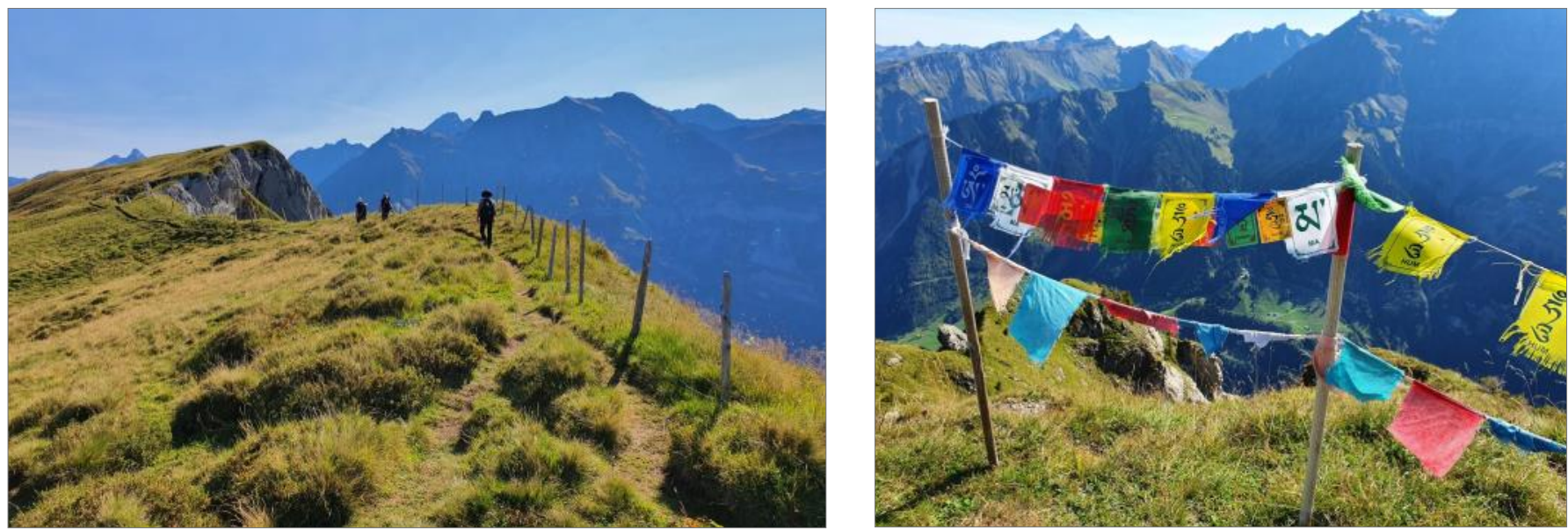

On the ridge, looking for a plot in limestone grassland (despite being over limestone, most of the grasslands were acidic here due to leaching of the top soil).
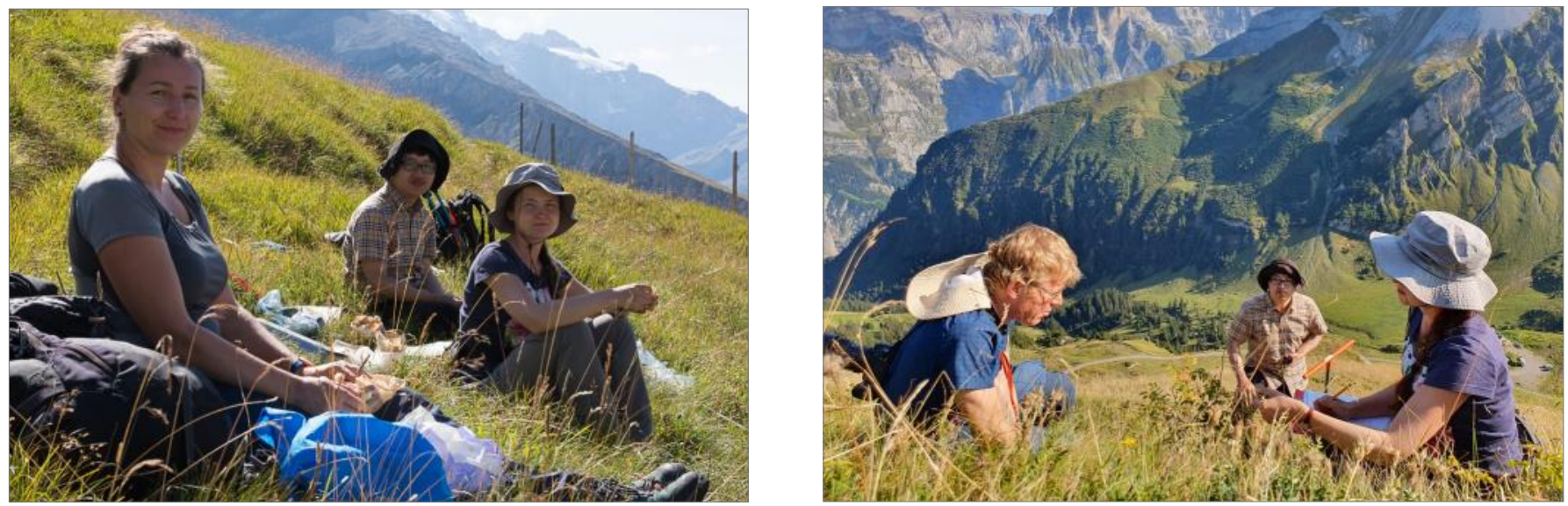

Picnic after several hours of sampling to obtain the richest plot ever (CHA25) (left) and the last plot of this Field Workshop (CHA26) (right). 


\section{Selected pictures of vascular plants}

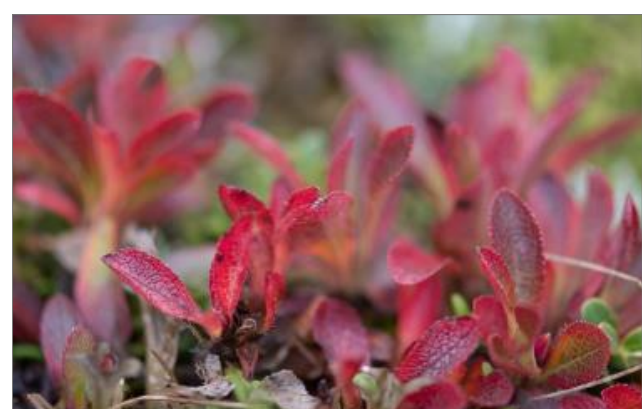

Arctostaphylos alpina

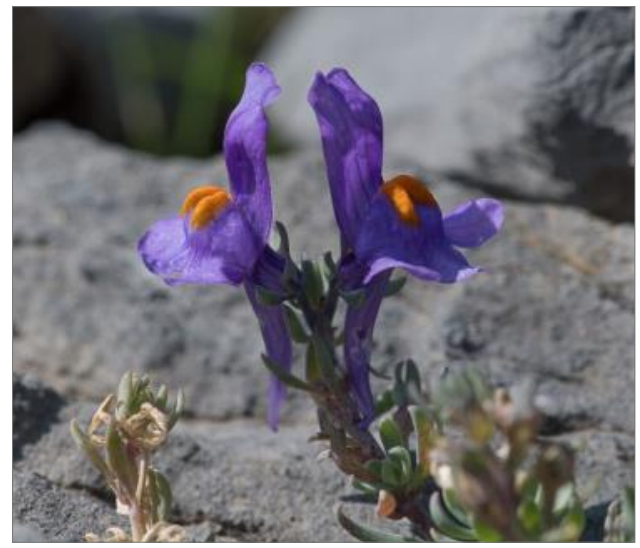

Linaria alpina

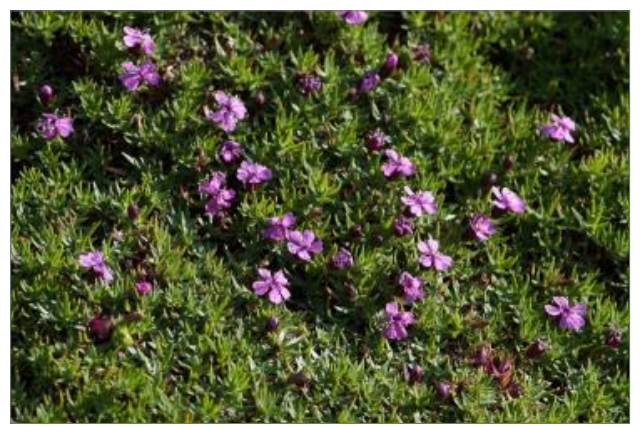

Silene acaulis

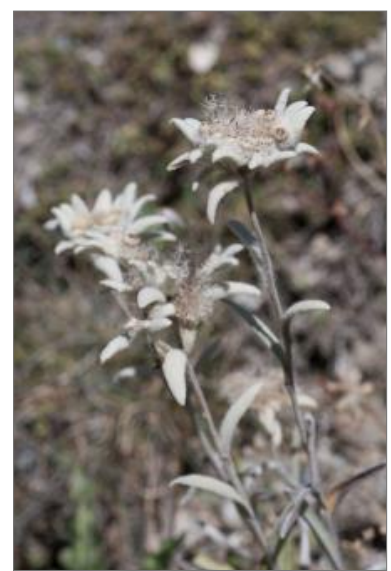

Leontopodium alpinum

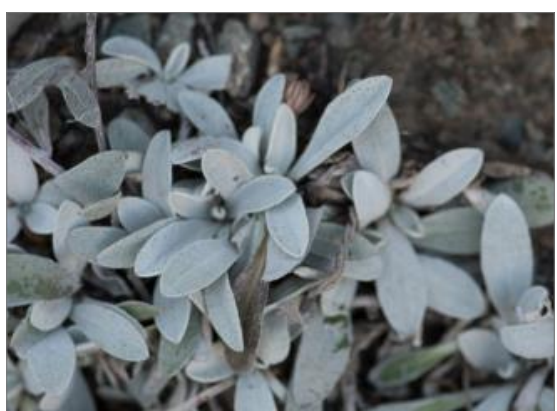

Hieracium pilosella subsp. velutina (easily recognizable, ecologically and biogeographically distinct, but not yet accepted in the Swiss checklist)

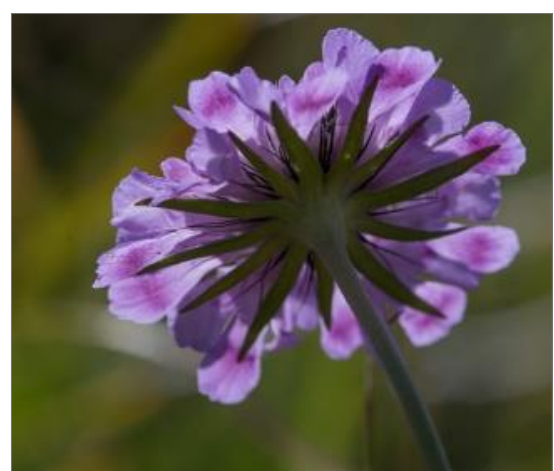

Scabiosa lucida

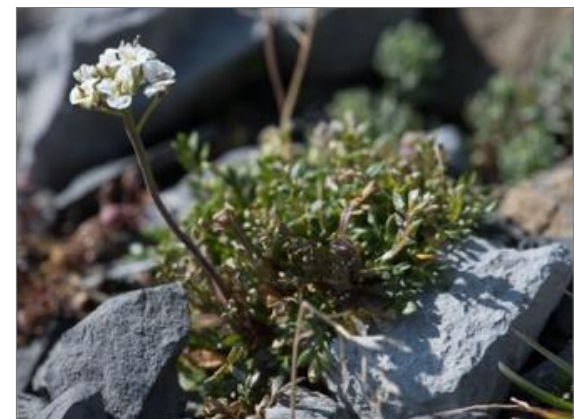

Pritzelago alpina

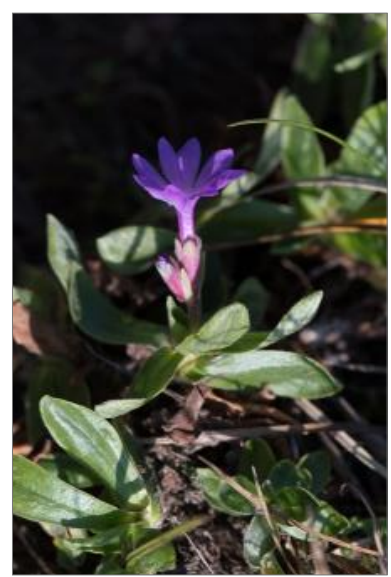

Primula integrifolia

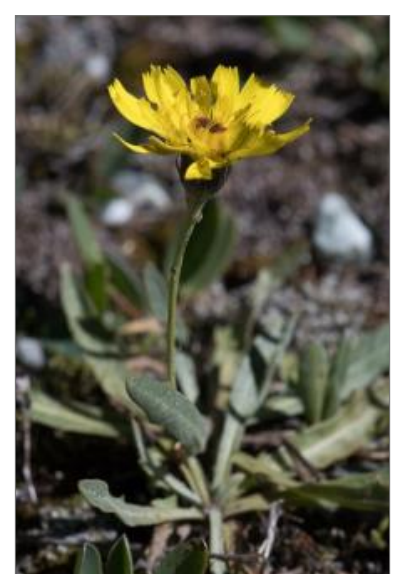

Hieracium staticifolium

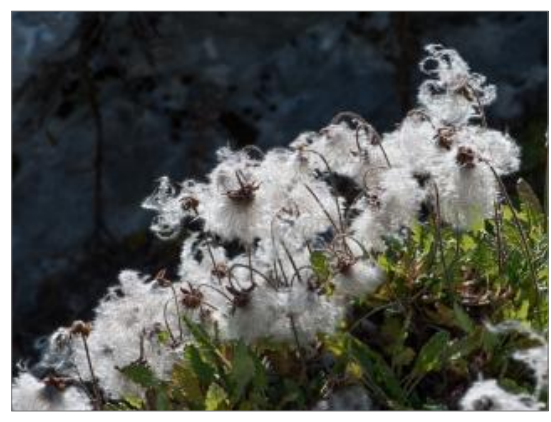

Dryas octopetala

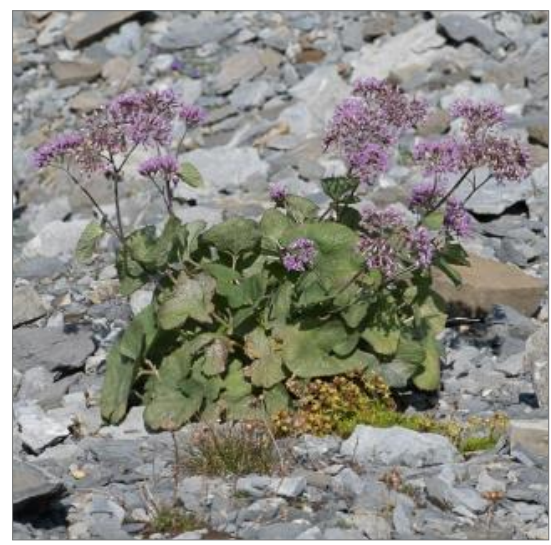

Adenostyles alpina

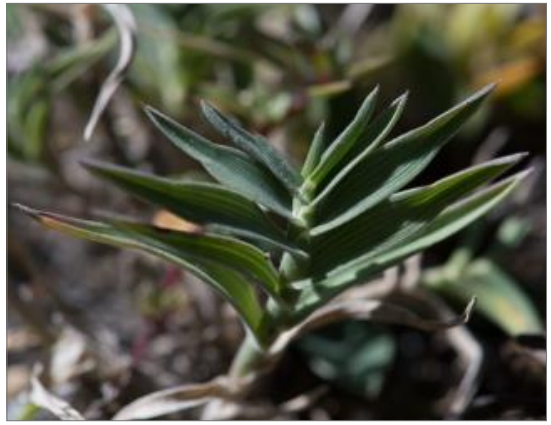

Trisetum distichophyllum

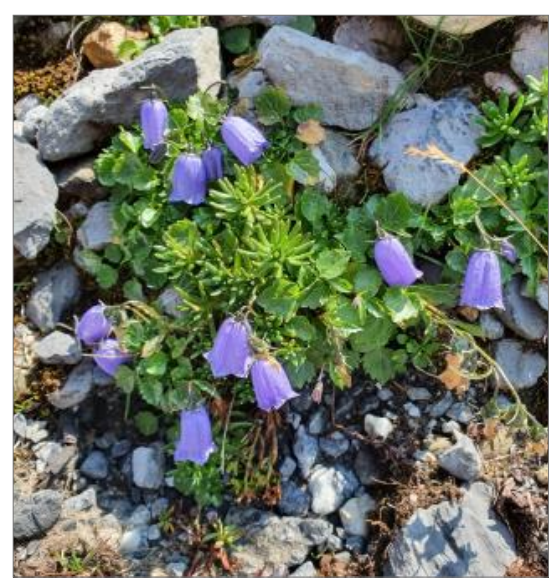

Campanula cochleariifolia 


\section{Selected pictures of bryophytes and lichens}

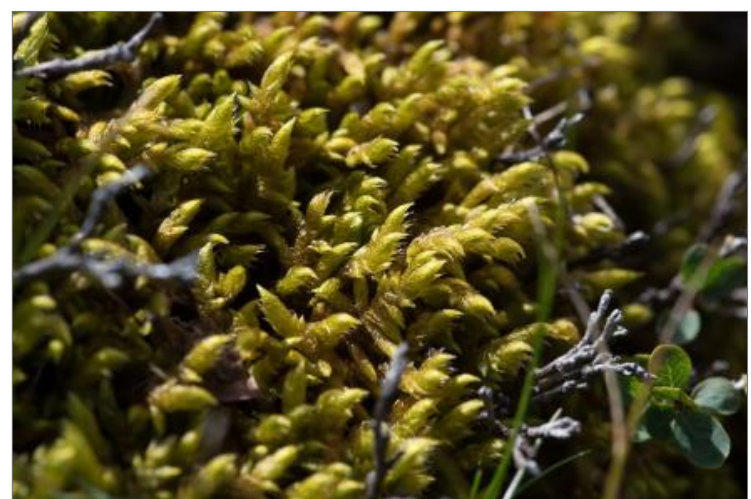

Rhytidium rugosum

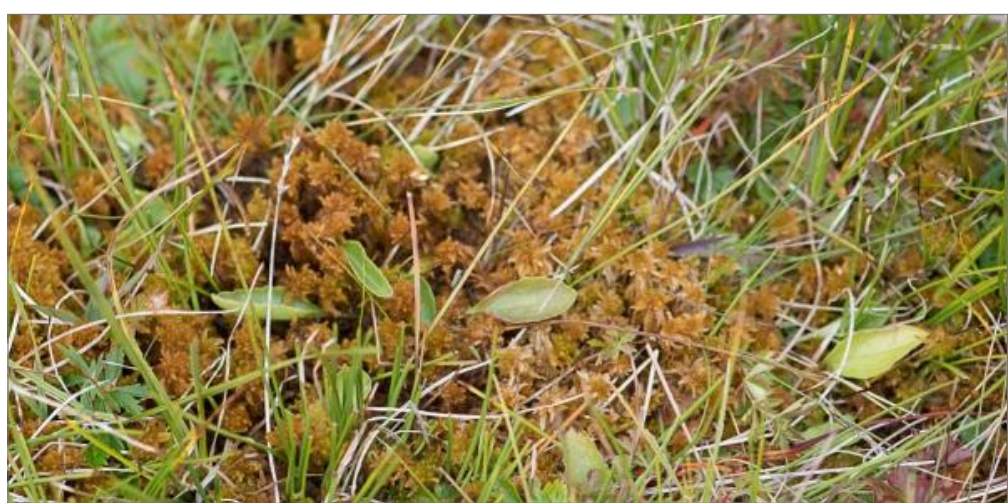

Sphagnum inundatum

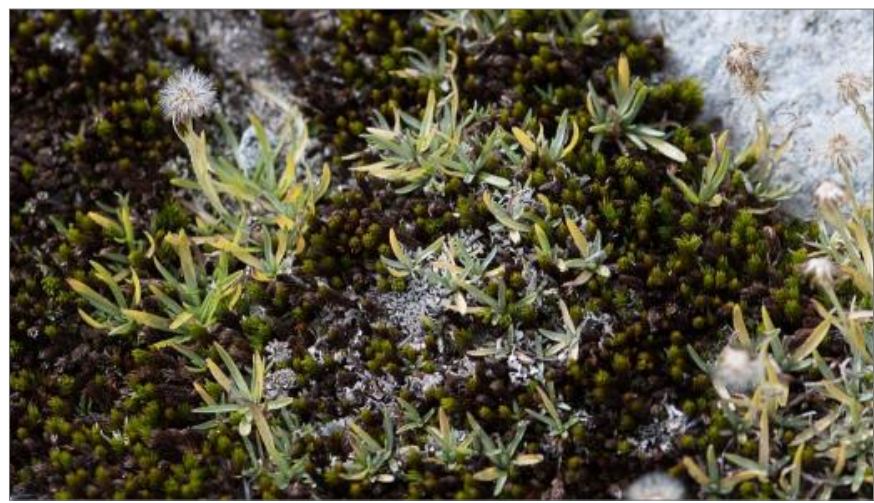

Polytrichastrum sexangulare

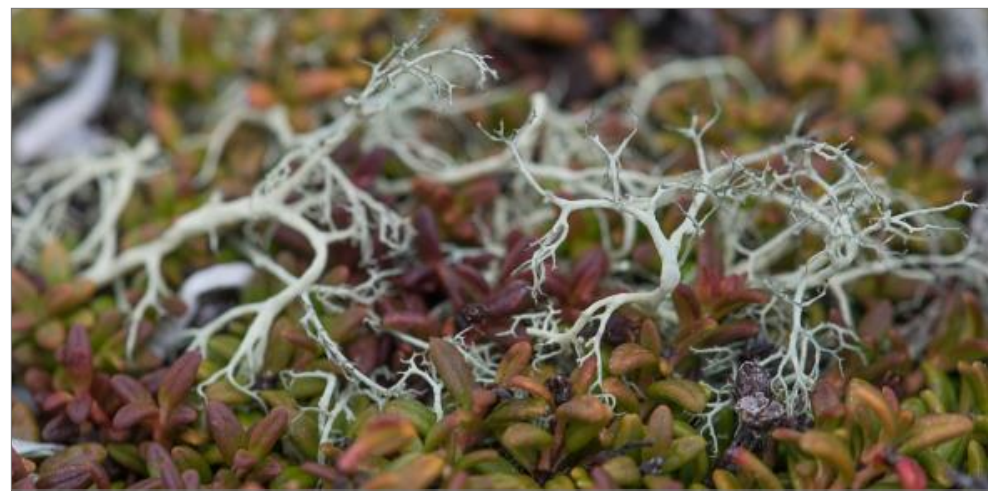

Alectoria ochroleuca

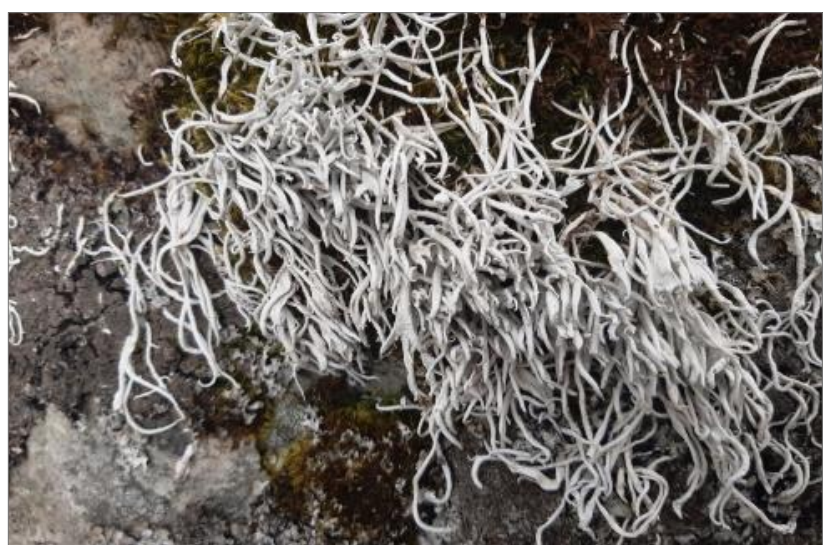

Thamnolia vermicularis

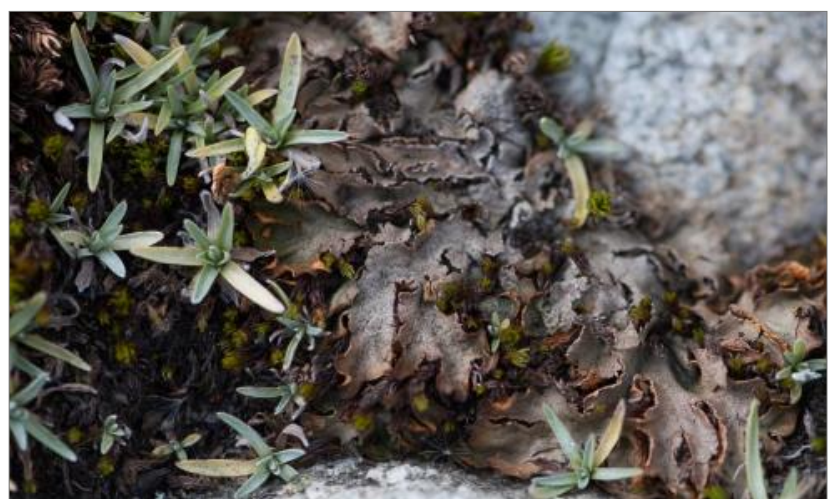

Solorina crocea

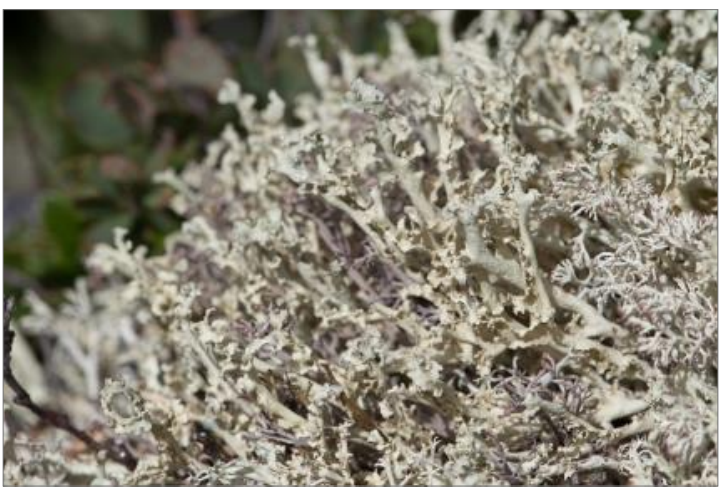

Flavocetraria cucullata

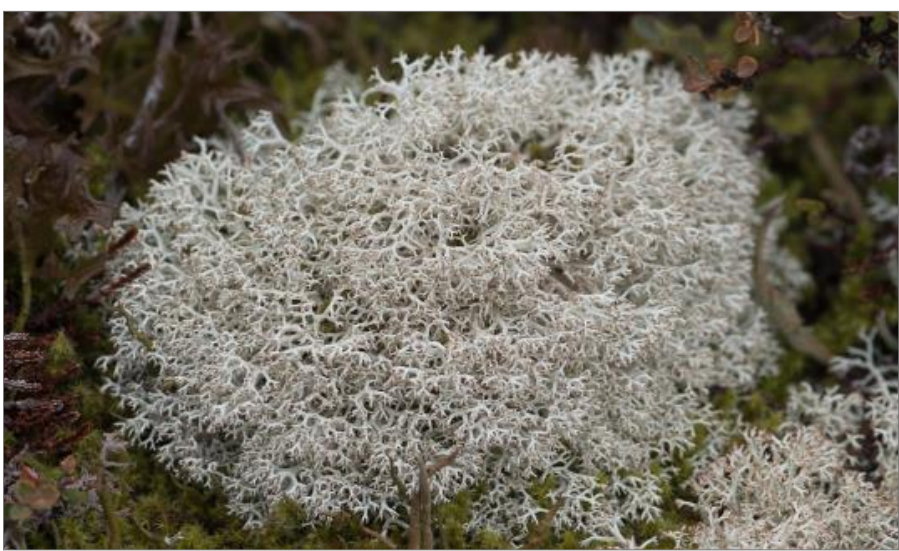

Cladonia arbuscula 


\section{Participants of the $14^{\text {th }}$ EDGG Field Workshop in Switzerland}

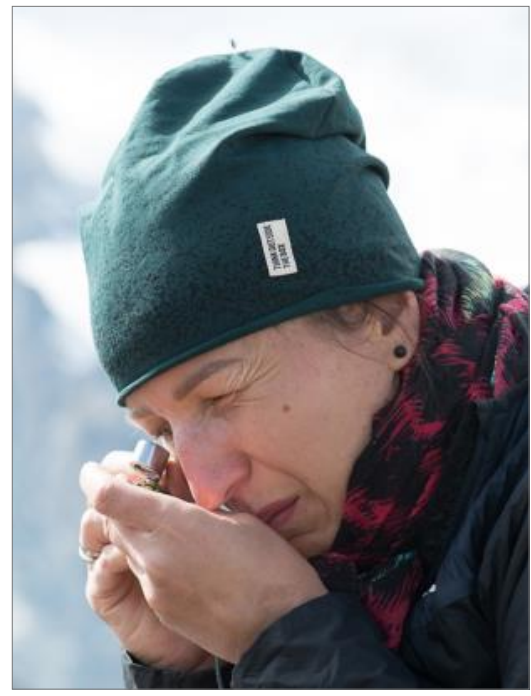

Beata Cykowska-Marzencka

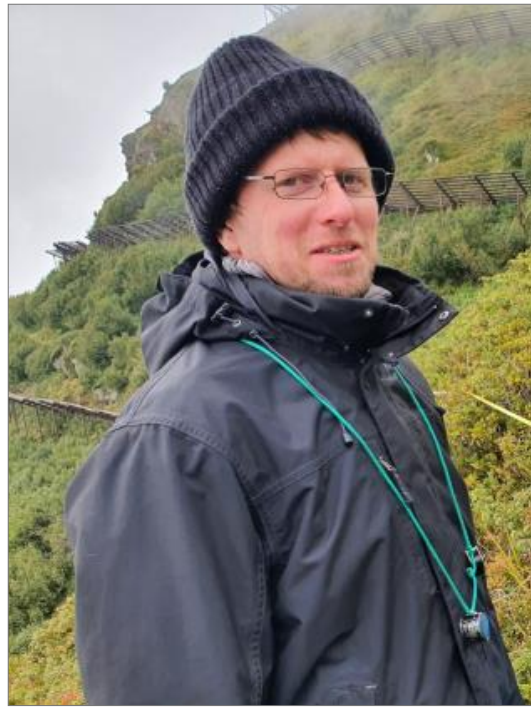

Patrick Neumann

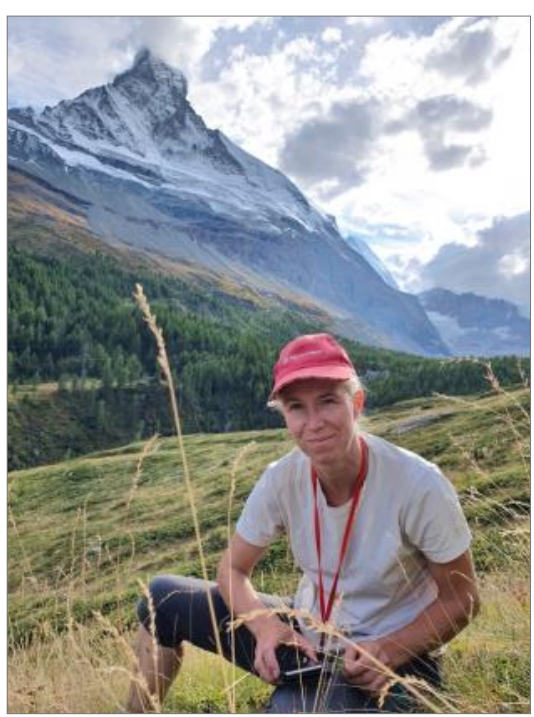

Susanne Riedel

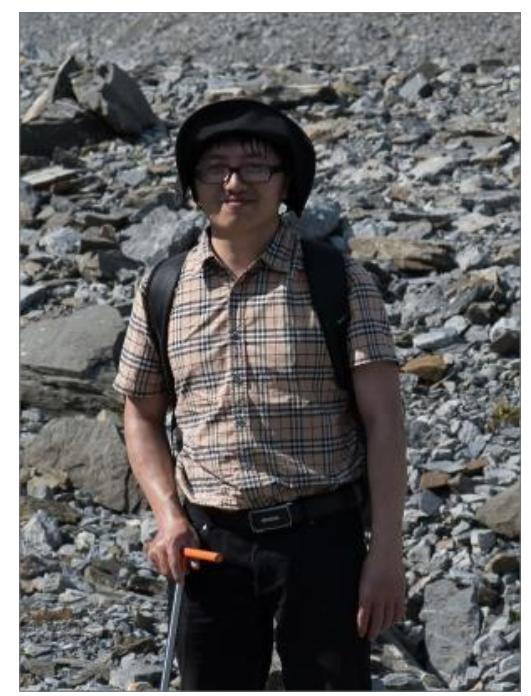

Jinghui Zhang

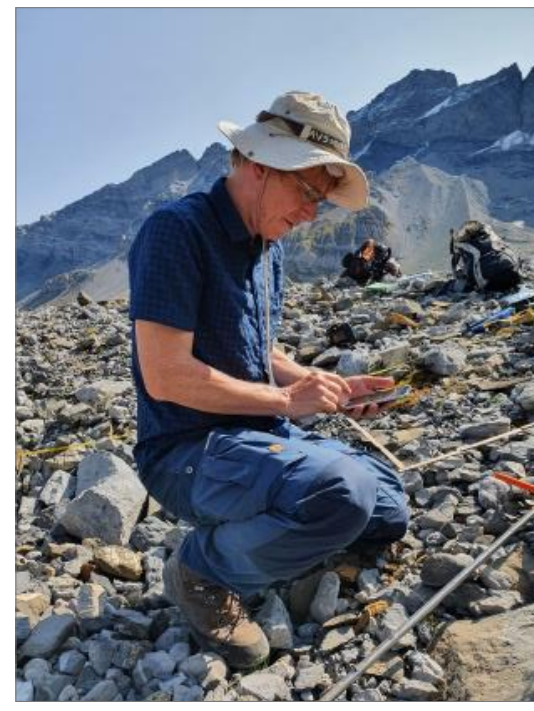

Jürgen Dengler

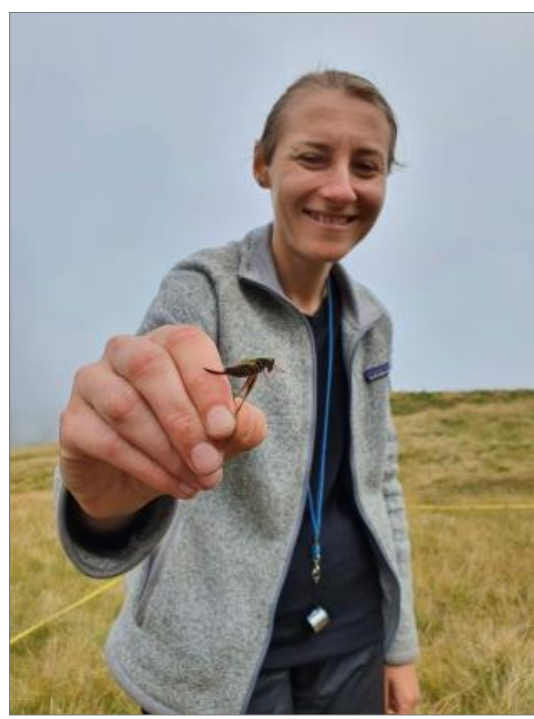

Hallie Seiler

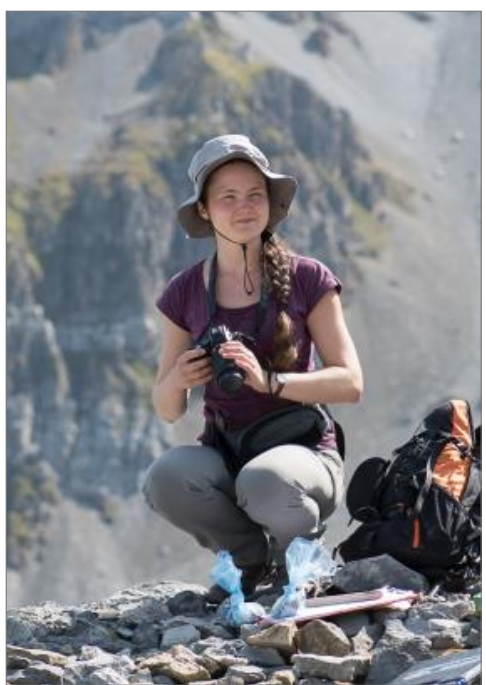

Iwona Dembicz

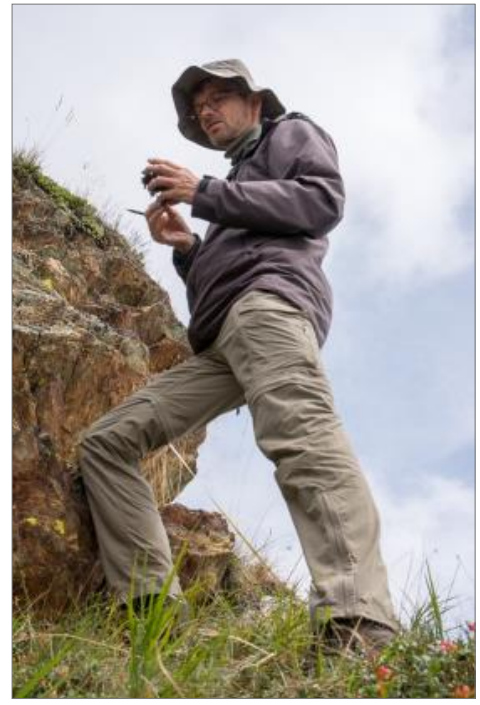

Christian Dolnik

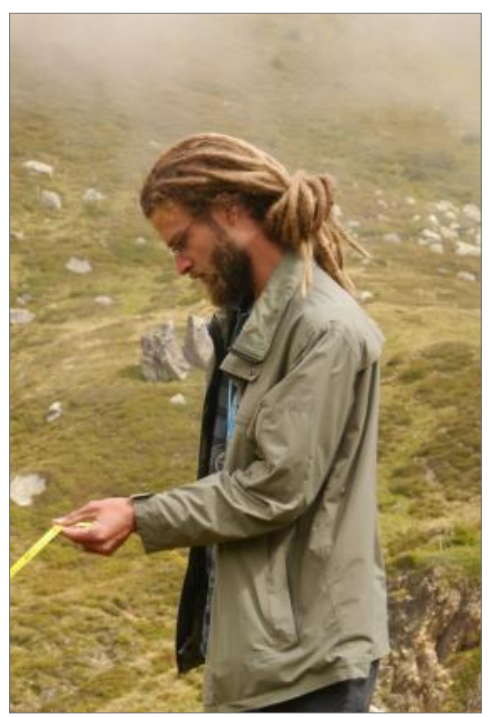

Timon Bruderer 


\title{
Grasslands of the mineral islands in the Biebrza National Park, Poland
}

\author{
Photos and text by Iwona Dembicz ${ }^{1}$, Łukasz Kozub ${ }^{1}$, Inga Bobrowska ${ }^{1,2}$ \& Jürgen Dengler ${ }^{3,4,5}$
}

${ }^{1}$ Department of Ecology and Environmental Conservation, Institute of Environmental Biology, Biological and Chemical Research Centre, Faculty of Biology, University of Warsaw, ul. Żwirki i Wigury 101, 02-089 Warsaw, Poland, e-mails: I. Dembicz: i.dembicz@gmail.com, Ł. Kozub: lukasz.kozub@biol.uw.edu.pl, I. Bobrowska: borsuczanka@gmail.com

${ }^{2}$ College of Inter-faculty Individual Studies in Mathematics and Natural Sciences, University of Warsaw, ul. Stefana Banacha 2c, 02-097 Warsaw

The Biebrza National Park is located in Northeast Poland (Fig. 1), in the basin of the river Biebrza. The park was established in 1993. It is the largest national park in Poland with a total area of 59,233 ha, of which 25,494 ha are wetlands. The Biebrza marshes, fens and wet meadows are famous particularly for their very diverse avifauna with many rare
${ }^{3}$ Vegetation Ecology, Institute of Natural Resource Management (IUNR), Zurich University of Applied Sciences (ZHAW), Grüentalstr. 14, 8820 Wädenswil, Switzerland; e-mail: dr.juergen.dengler@gmail.com

${ }^{4}$ Plant Ecology, Bayreuth Center of Ecology and Environmental Research (BayCEER), University of Bayreuth, Universitätsstr. 30, 95447 Bayreuth, Germany

${ }^{5}$ German Centre for Integrative Biodiversity Research (iDiv) Halle-JenaLeipzig, Deutscher Platz 5e, 04103 Leipzig, Germany

species, such as aquatic warbler (Acrocephalus paludicola) and greater spotted eagle (Clanga clanga). The park was designated as a wetland site of global significance and is under the protection of the Ramsar Convention.

The park landscapes are not wild, but represent one of the last large remnants of semi-natural landscapes of river val-

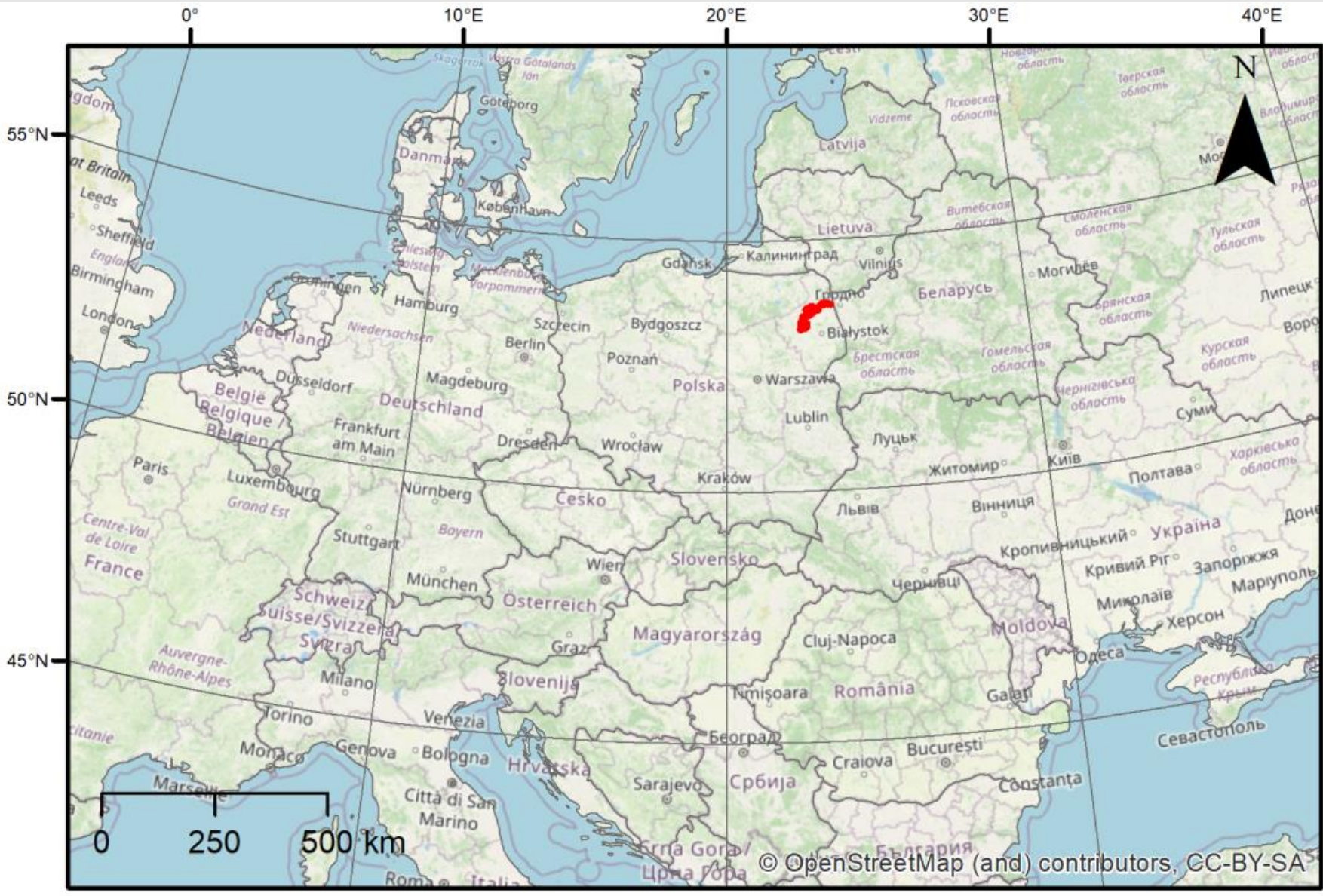

Fig. 1. Location of the Biebrza National Park (marked in red). 
leys of lowland temperate Europe once stretching from Belgium and the Netherlands to the Polesia region in Belarus and Ukraine along the southern margins of the Pleistocene glaciation. However, the park and the valley are more than wetlands: embedded in the wet plains, there are small mineral islands with mesic or even dry habitats, isolated or arranged in distinct archipelagos. We call them 'mineral islands' as they are built mostly of sand in contrast to the organic soil of the surrounding wetlands. Those mineral islands are of various origins: mostly aeolian, being tops of dunes formed during the dry early Holocene, which then became largely submerged in the growing fen peat, but also fluvial or glaciofluvial. The size is variable (from just a few hundreds of square meters up to a few hectares) as well as their height above the wetlands (from nearly flat to about a dozen meters). Their sandy soils are drought-prone and are often quite calcium rich.

In the past, when the whole valley was used by local people mostly for cattle husbandry, also the mineral islands were used for grazing. The largest ones even had permanent settlements with small arable fields. Since the mid- $20^{\text {th }}$ century, traditional agriculture has successively disappeared from the valley but free-ranging cattle still roam some of the mineral islands. Others are slowly converting to oak-limehornbeam forests but a significant portion is still kept open by large populations of wild ungulates (wild boar, roe deer, red deer and the king of the wetland - the elk).

Mineral islands are known as biodiversity hotspots of the area. It is estimated that they support half of the national park flora, although they cover only a small fraction of the park area. Some plant species of dry grassland and thermophilous forests occur here in isolated outposts, far from the main range (e.g. Iris aphylla, Cimicifuga europaea and Gymnadenia conopsea), and other, overall very rare, form numerous populations (Cypripedium calceolus, Pulsatilla patens, Dracocephalum ruyschiana, Thesium ebracteatum). The same applies for animals, especially insects, including Phengaris (Maculinea) arion and Parnassius mnemosyne. The vegetation of those hills generally comprises dry sandy grasslands (both acidic and calcareous), Nardus grasslands, mesic and litter meadows, thermophilous fringe communities and even communities close to meso-xeric dry grasslands (despite prevalence of sandy substrates). However, no in-depth phytosociological studies have so far been carried out.

Regardless of their acknowledged values, the mineral islands are not receiving much attention from the national park authorities with respect to their active conservation. The main focus in the park is on conservation of seminatural wetland habitats and landscapes, and the dry hills are mostly left unmanaged or are managed only if they are in proximity of mown or grazed wetlands. Even though the pressure of ungulate browsers slows their succession towards forest, the lack of grazing, mowing and/or fire disturbance leads to deterioration of their habitats and dominance of strongly competitive grasses, such as Calamagrostis epigeios, Molinia caerulea, Bromus inermis or Brachypodium pinnatum.

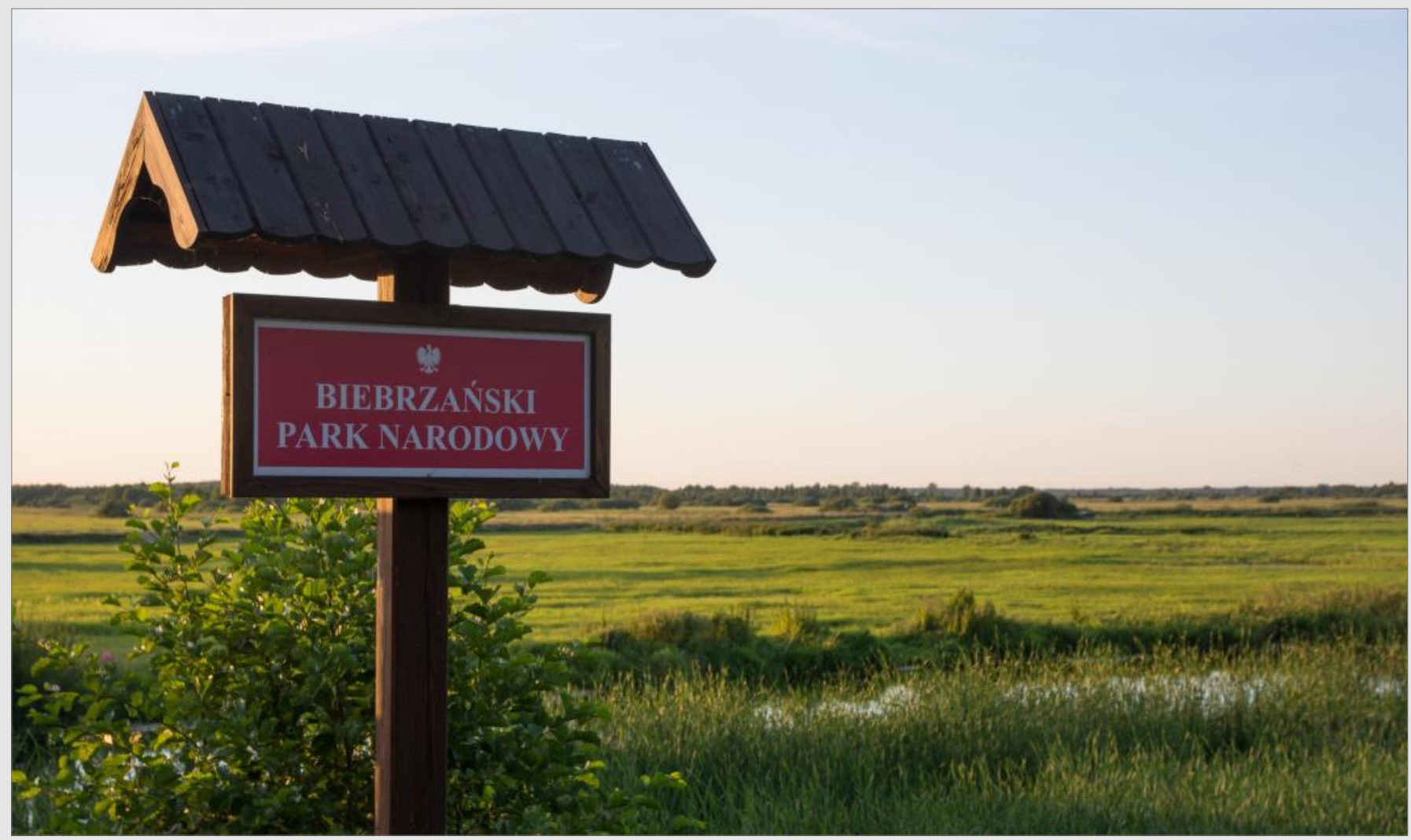

Sign at the border of the Biebrza National Park near Dolistowo Stare. Behind it is the Biebrza river and typical landscape of the national park: vast plains dominated by marshes, fens and wet meadows. Photo: J. Dengler. 


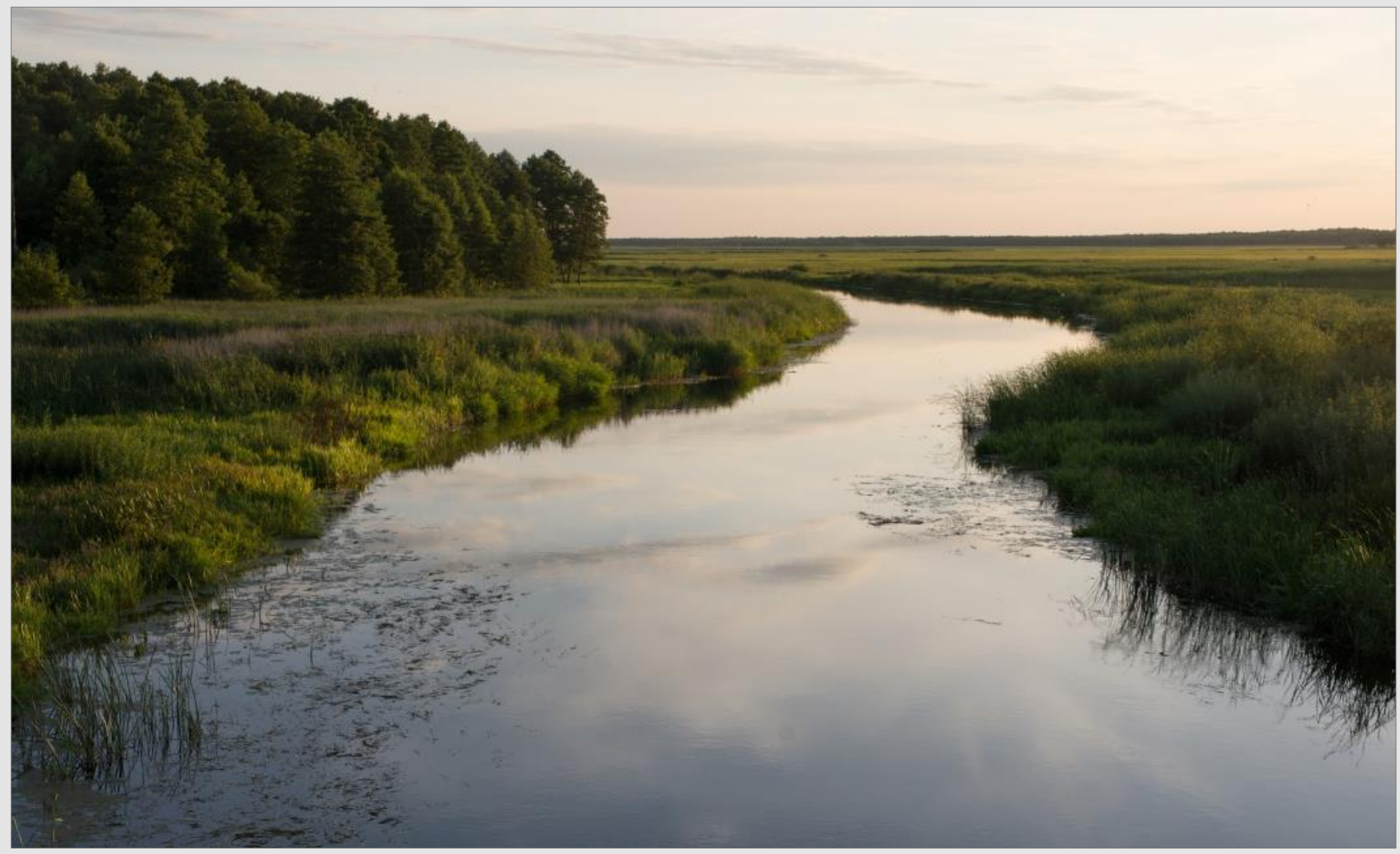

View of the Biebrza river from the bridge near Dolistowo Stare. Photo: J. Dengler.

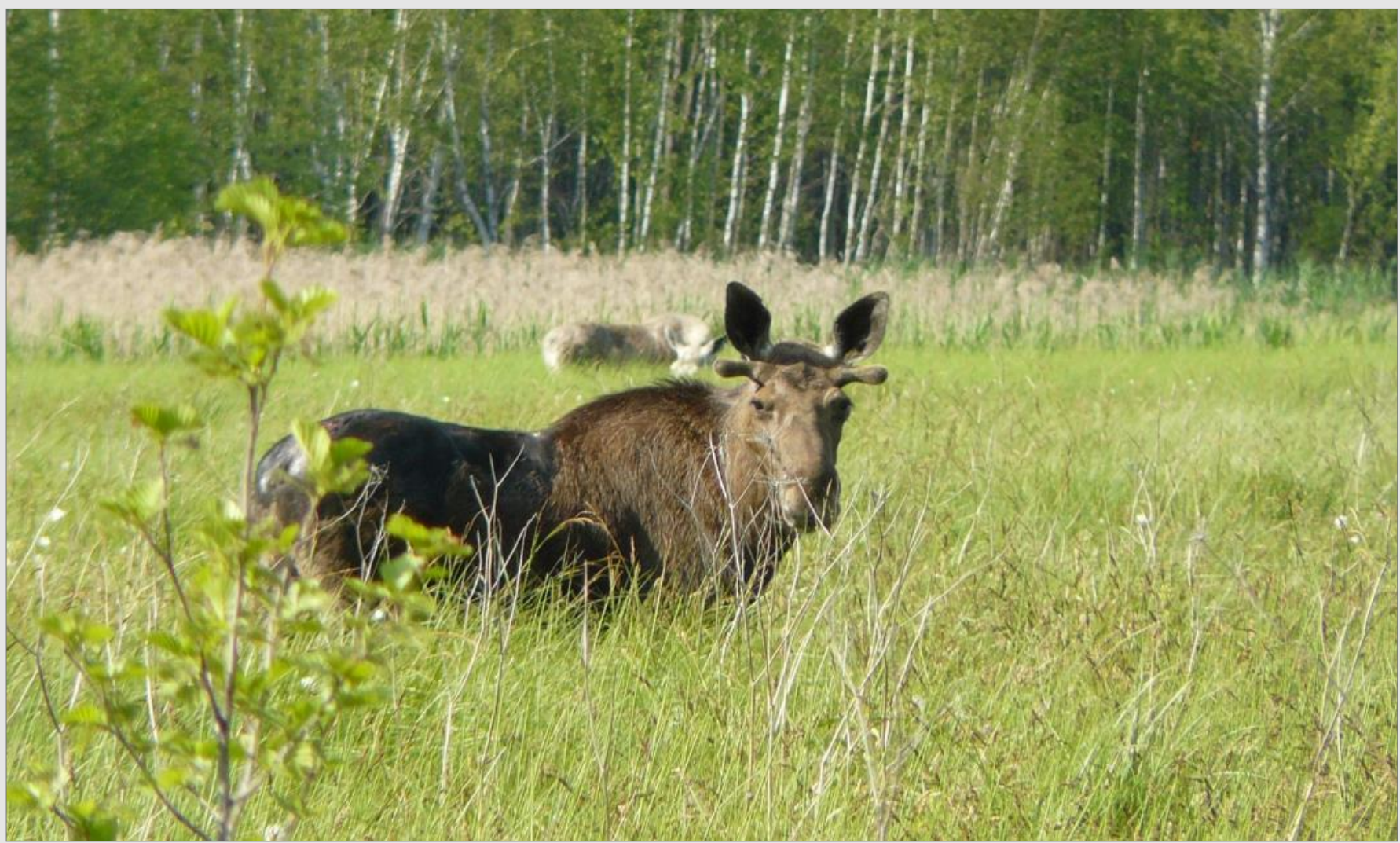

Two elk (Alces alces) within fen vegetation (fruiting Eriophorum angustifolium in the foreground). The Biebrza basin is very important for conservation of this emblematic species: it contains the largest population of this species in Poland, estimated at 1,400 individuals. Elk are browsers, which can help to preserve open vegetation on mineral islands. Photo: Ł. Kozub. 


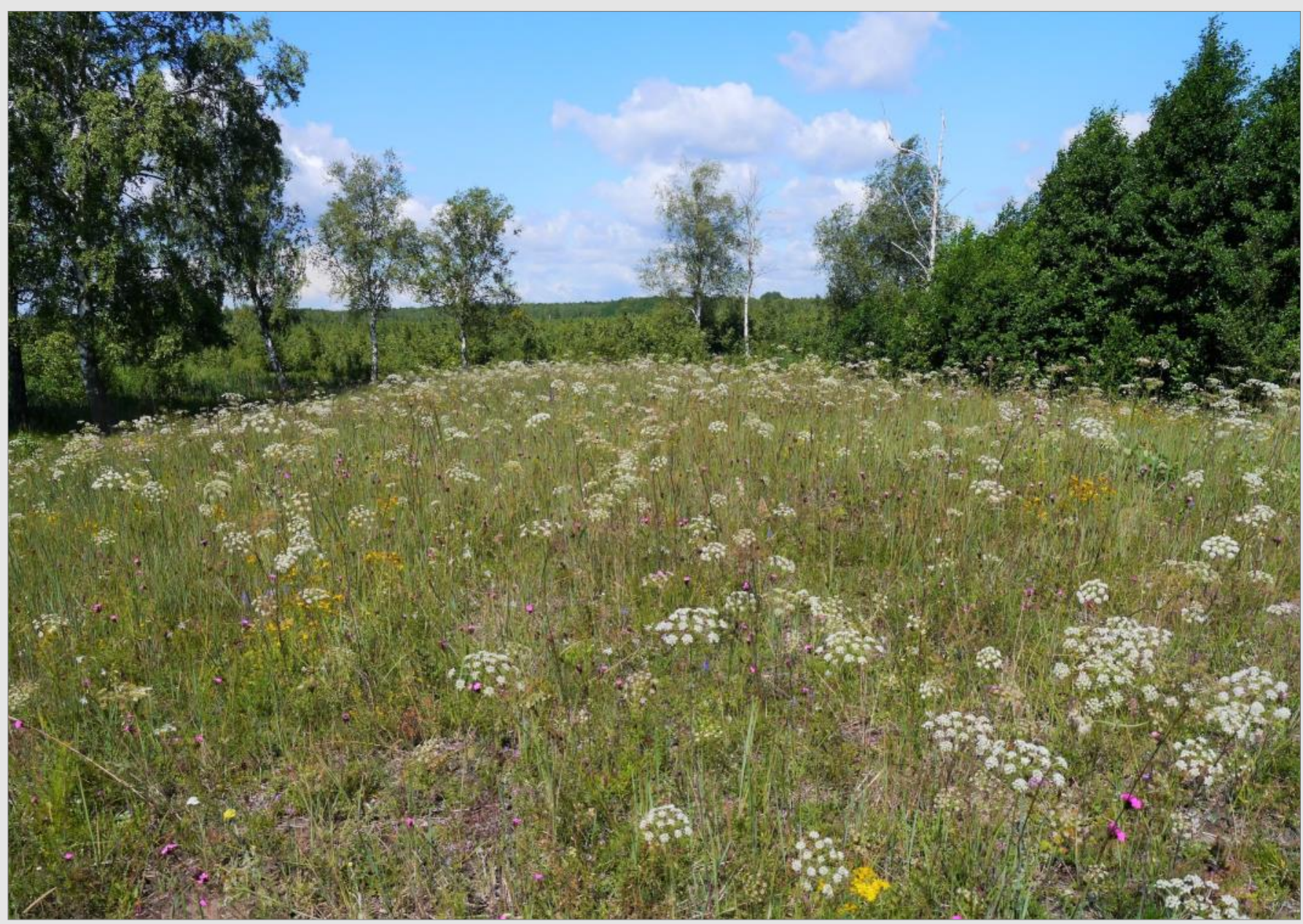

Top of the mineral island near Grzędy in the first half of July - a species rich patch of a dry grassland with flowering Peucedanum oreoselinum, Dianthus carthusianorum, Hypericum perforatum and Veronica spicata. Photo: I. Dembicz.

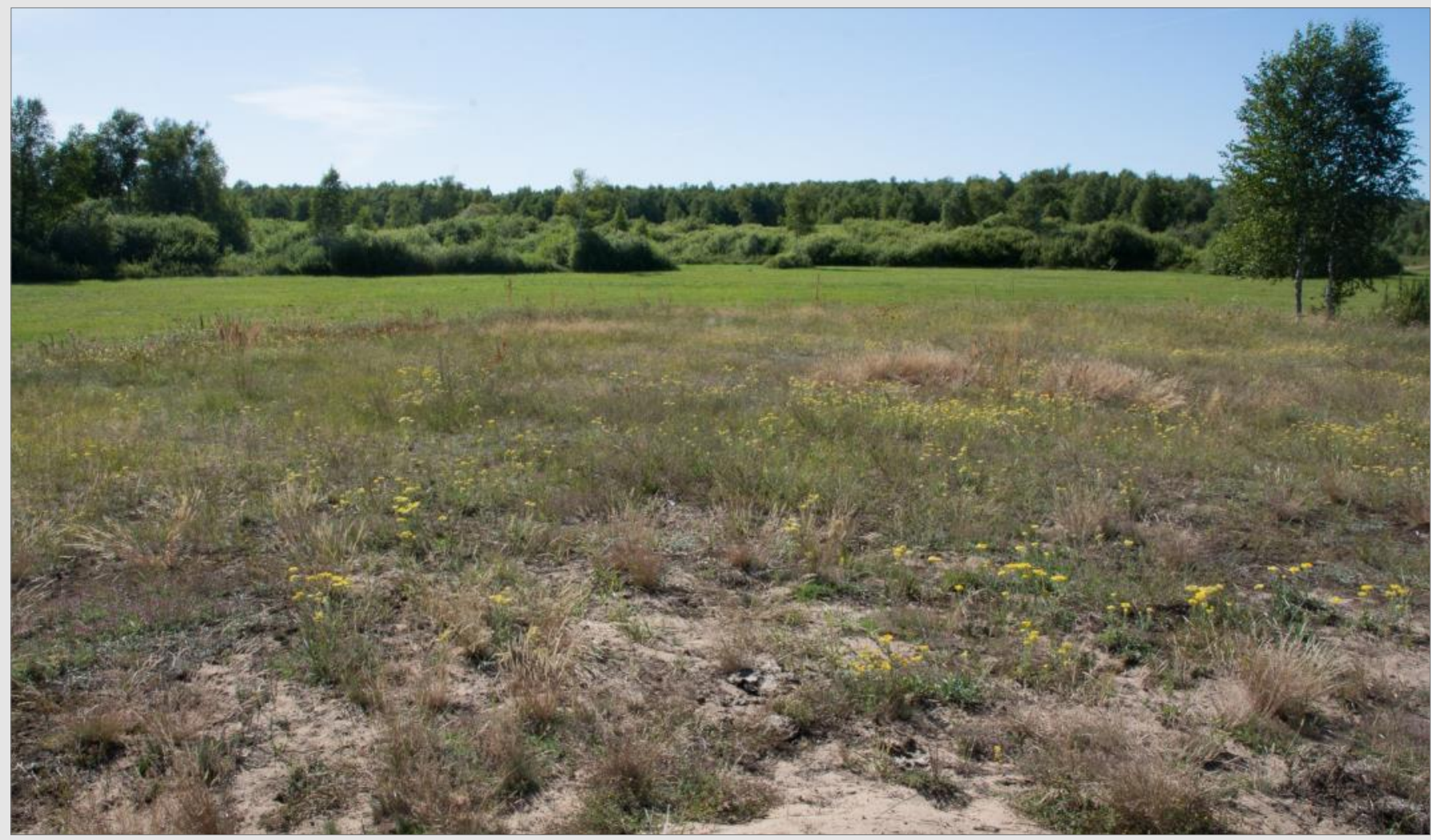

Dry grassland with Corynephorus canescens, Hieracium pilosella and Helichrysum arenarium on the top of a mineral Island near Polkowo, at the national park border, surrounded by intensively used meadows on drained peat. Photo: J. Dengler. 


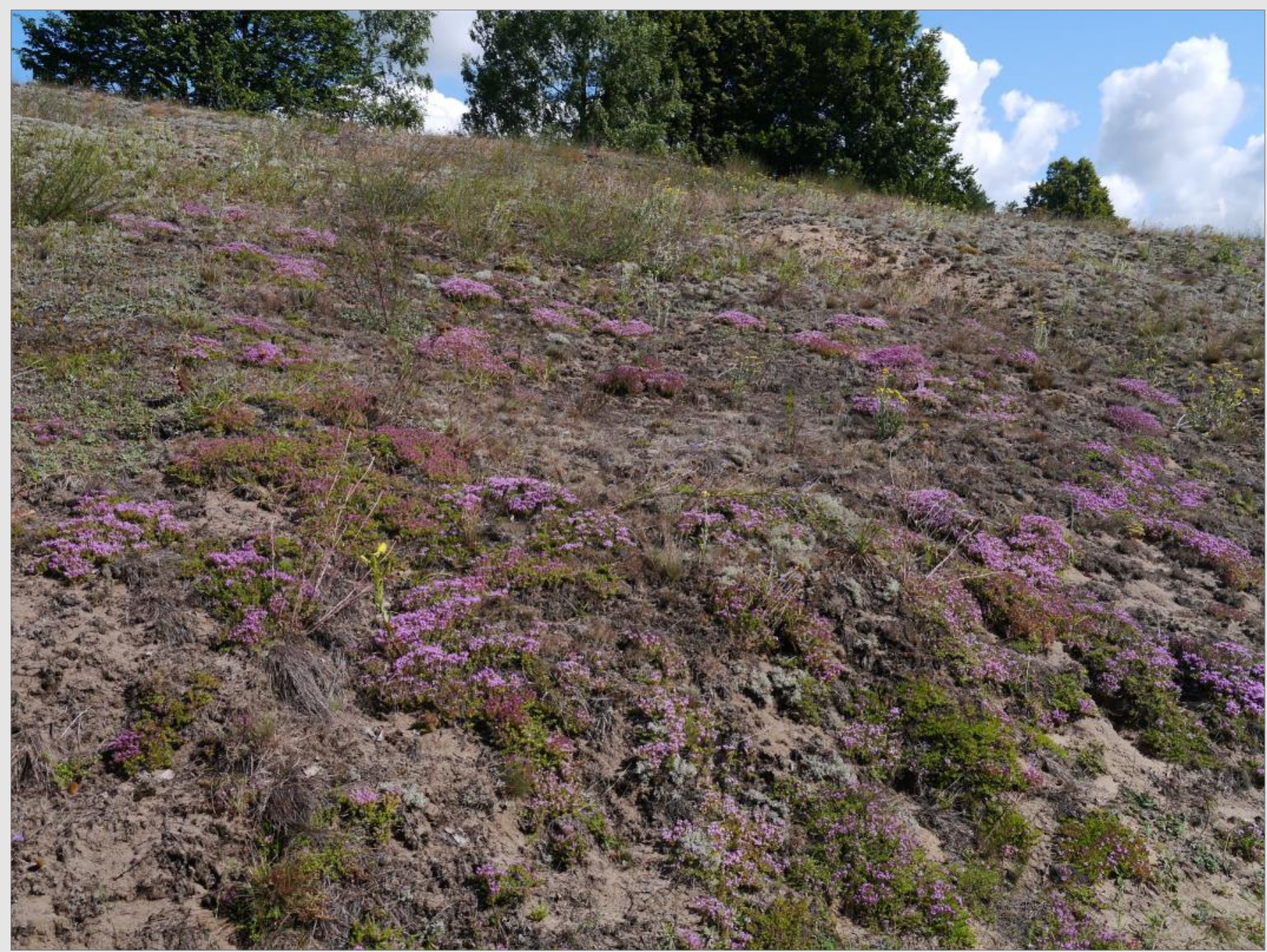

Slope of large mineral Island covered by dry psammophytic grassland with Thymus serpyllum. Photo: I. Dembicz.
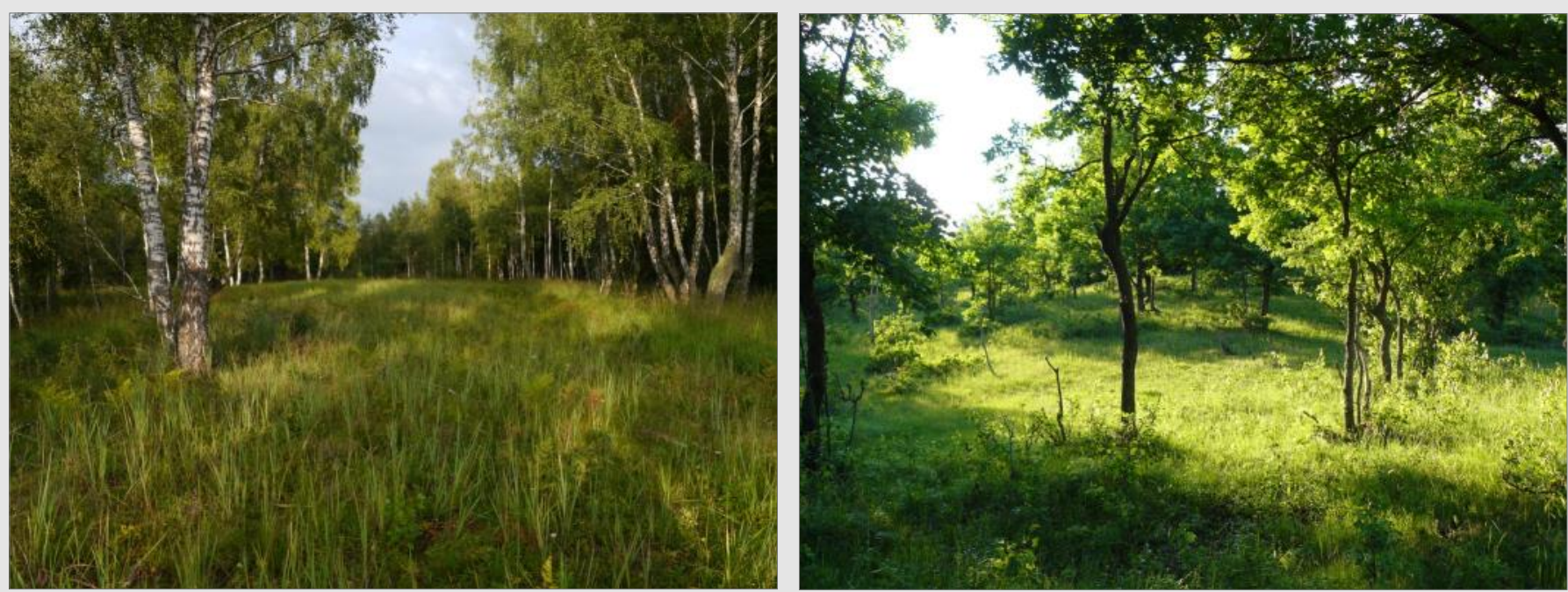

The most species-rich and valuable habitats of the mineral islands are light forests consisting mostly of birch Betula pendula (on the left) or oak Quercus robur (on the right) resembling forest-steppe mosaics of lowlands of Eastern Europe or even Western Siberia. Photos: I. Dembicz, t. Kozub. 


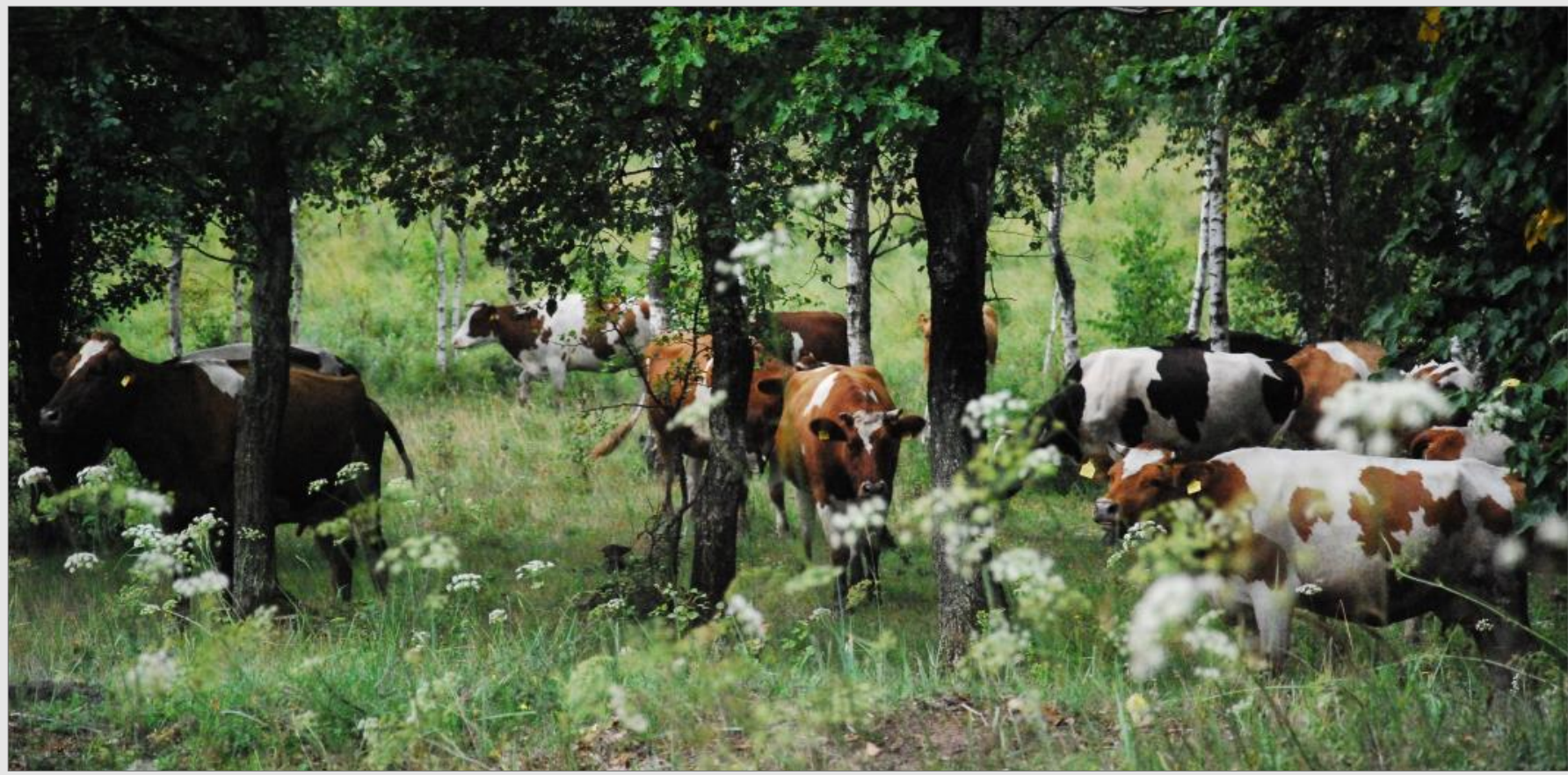

In the southern part of the Biebrza National Park a few herds of free-ranging cattle are still present. Each morning they walk from their barn many kilometres into the fens on their own, often resting on the mineral islands, and return in the evening to their owner. Photo: I. Bobrowska.

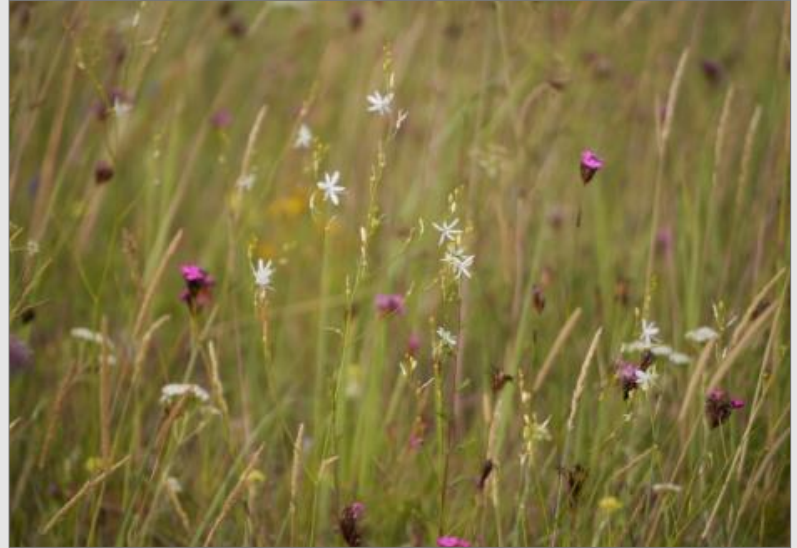

Colourful dry grassland with blooming Anthericum ramosum, Dianthus cathusianorum and the grasses Phleum phleoides and Koeleria grandis. Photo: I. Dembicz.

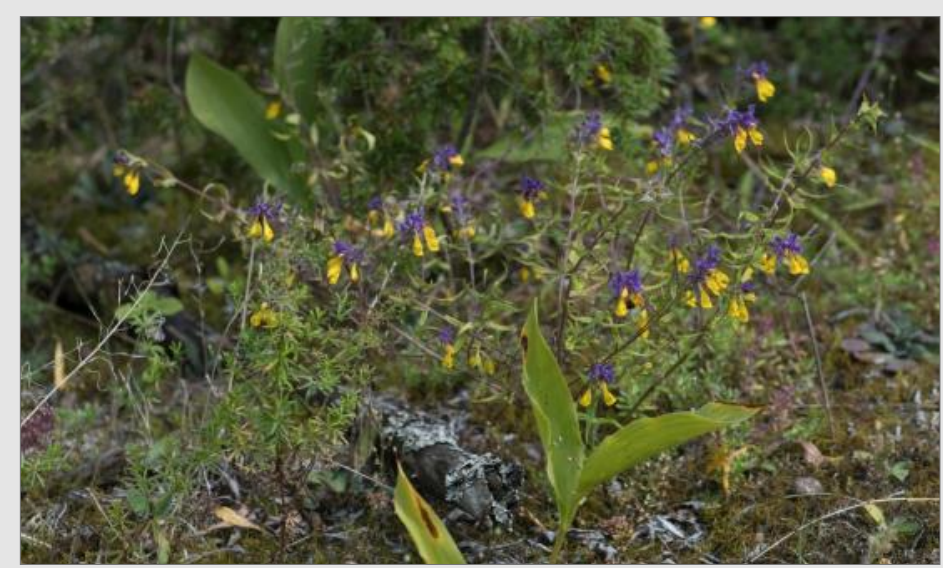

Fringe community with Melampyrum nemorosum, Convallaria majalis and Galium album. Photo: J. Dengler.

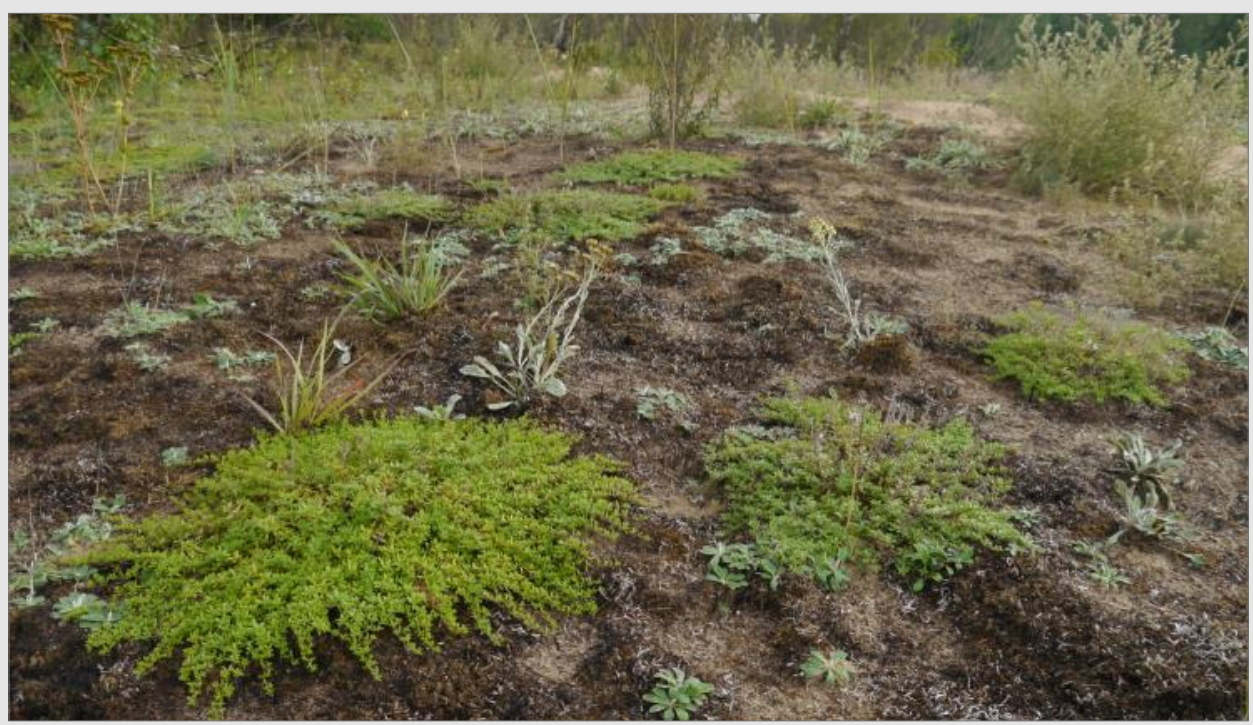

During the exceptionally dry spring of 2020, a large fire has spread over large areas of the Biebrza National Park. The fire mostly burned reed and sedge beds but some of the mineral islands were also impacted. In summer 2020, mosses and lichens still were affected while Thymus serpyllum has regrown fast. Photo: I. Dembicz. 


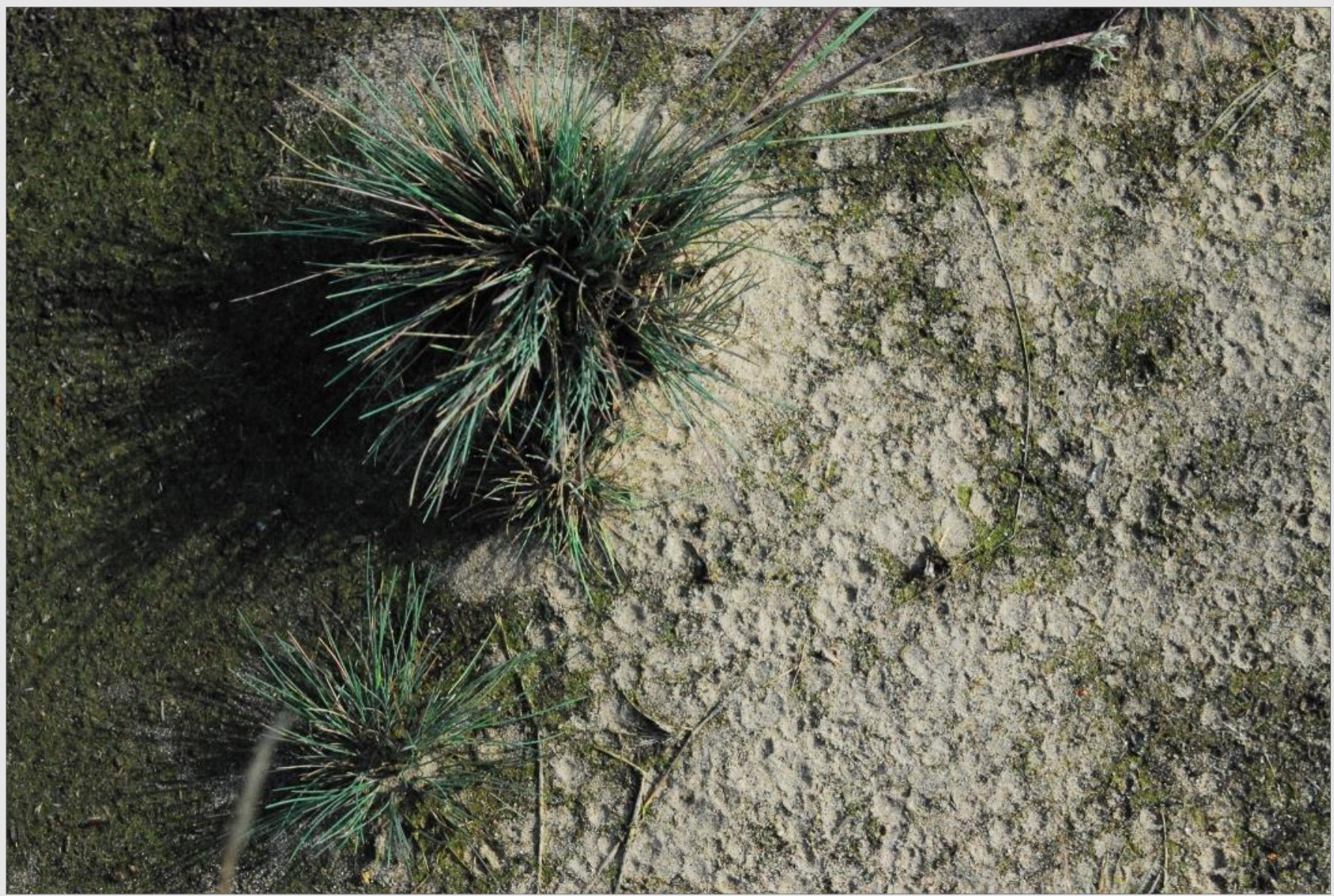

After the rain, droplets of water falling from the birch tree on the sand and breaking algal soil crust form a distinct pattern around Corynephorus canescens tussocks. Photo: I. Bobrowska.
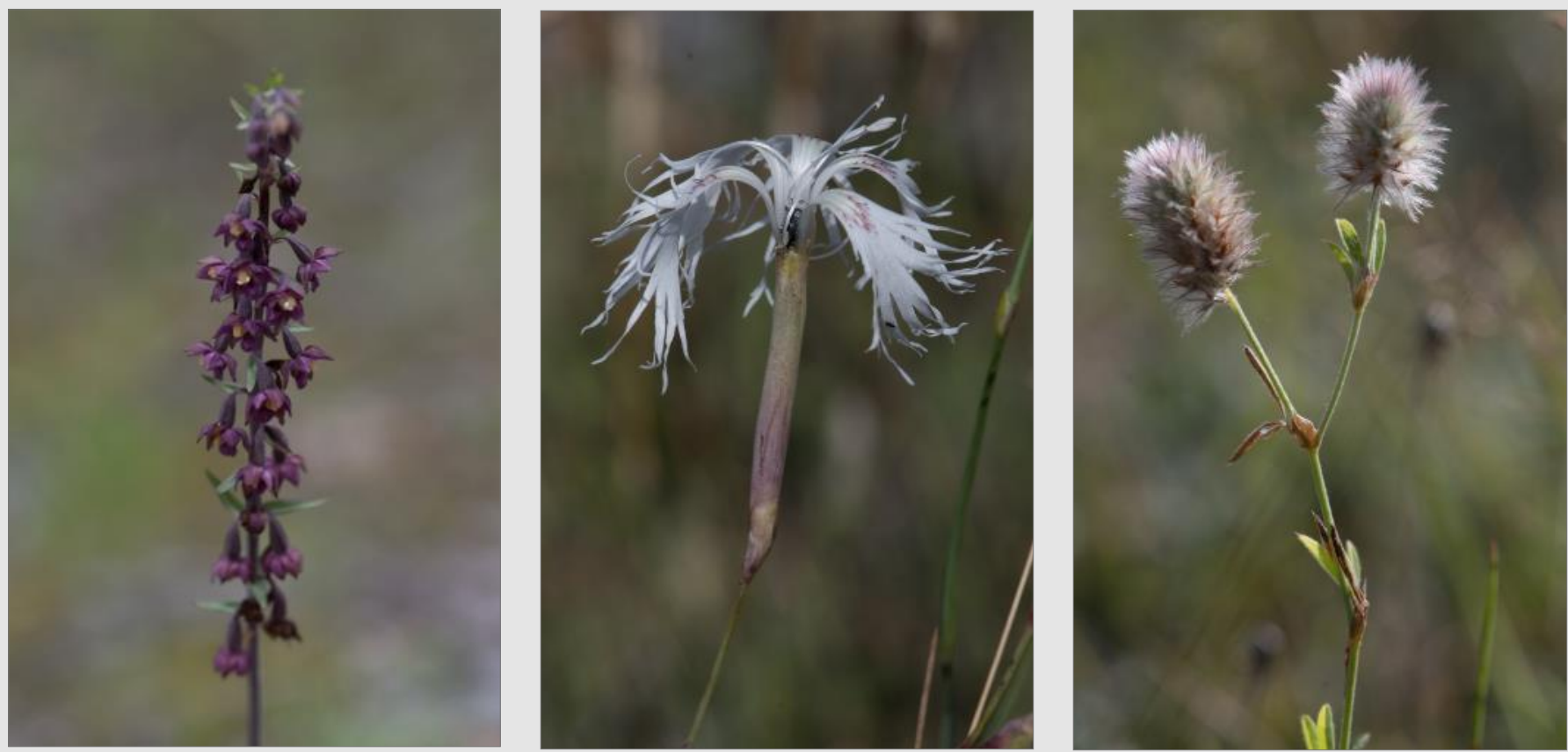

Plants of the sandy soils, occurring in both grassland and forest fringe communities: Epipactis atrorubens, Dianthus arenarius and Trifolium arvense. Photos: J. Dengler. 

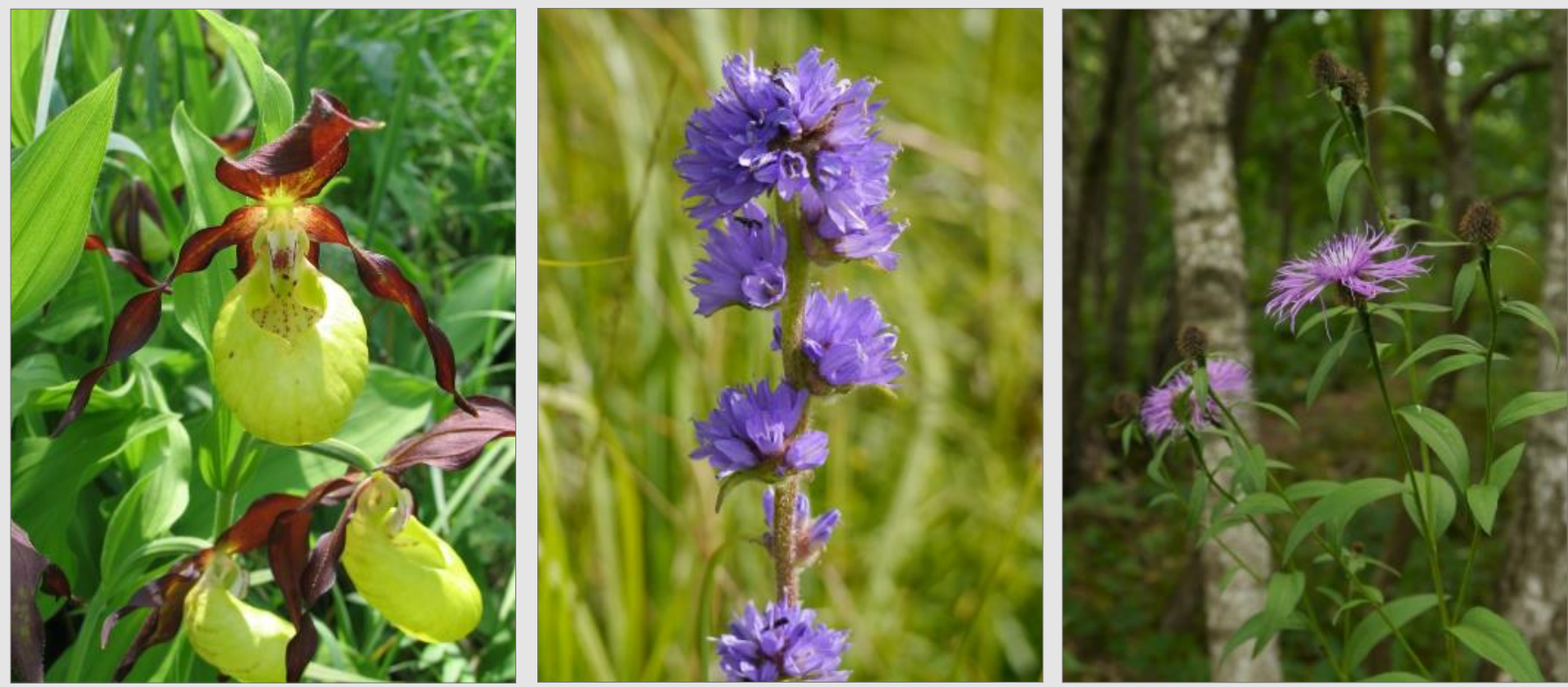

Forest fringes and light forests are home to many tall herbs with large and colourful flowers as (from the left to the right): Cypripedium calceolus, Campanula cervicaria and Centaurea phrygia. Photos: I. Dembicz.

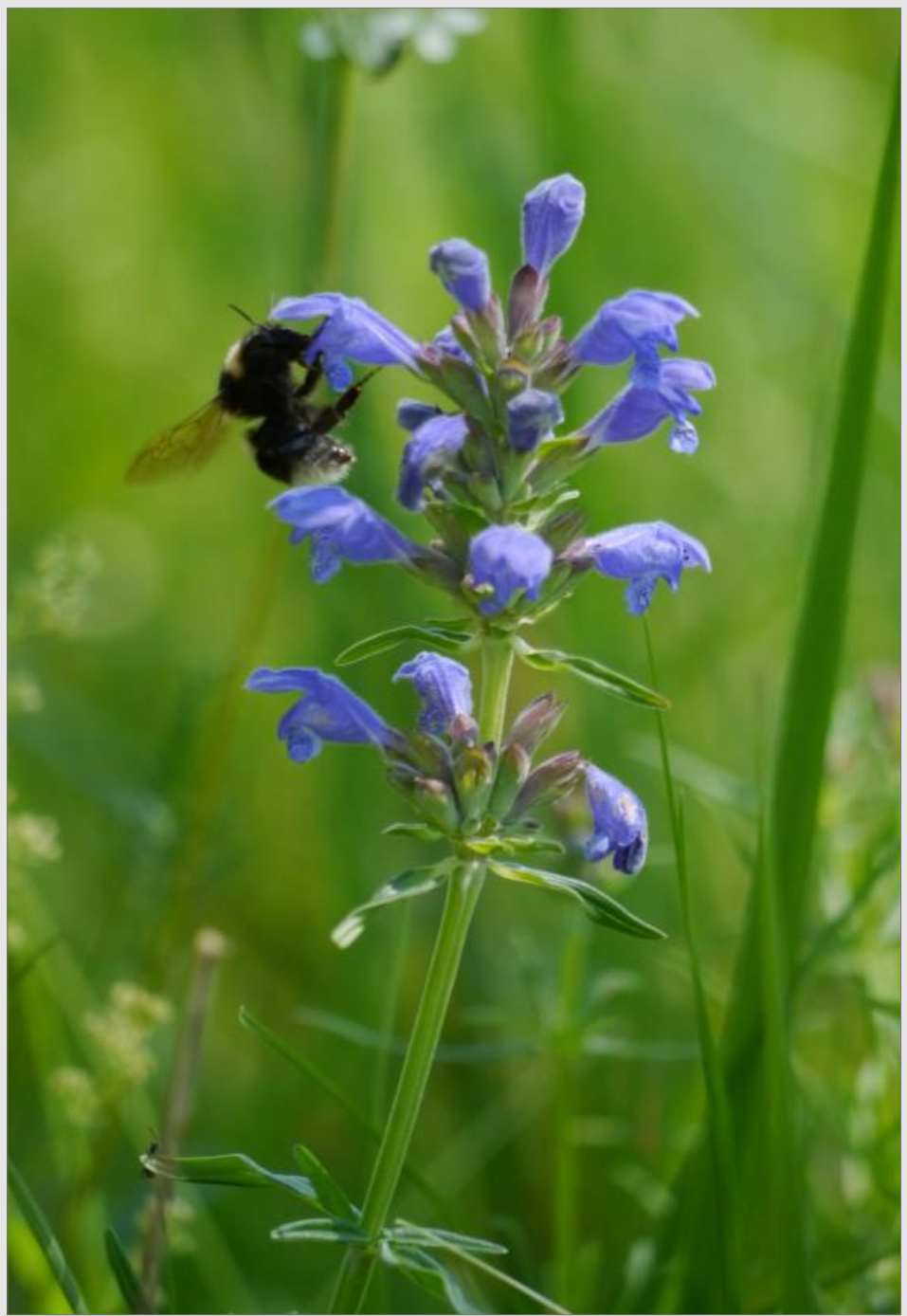

The mineral islands of the Biebrza valley are the last stronghold for Dracocephalum ruyschiana, one of the rarest plants of Poland. On the picture with its pollinator Bombus lucorum agg. Photo: I. Dembicz.
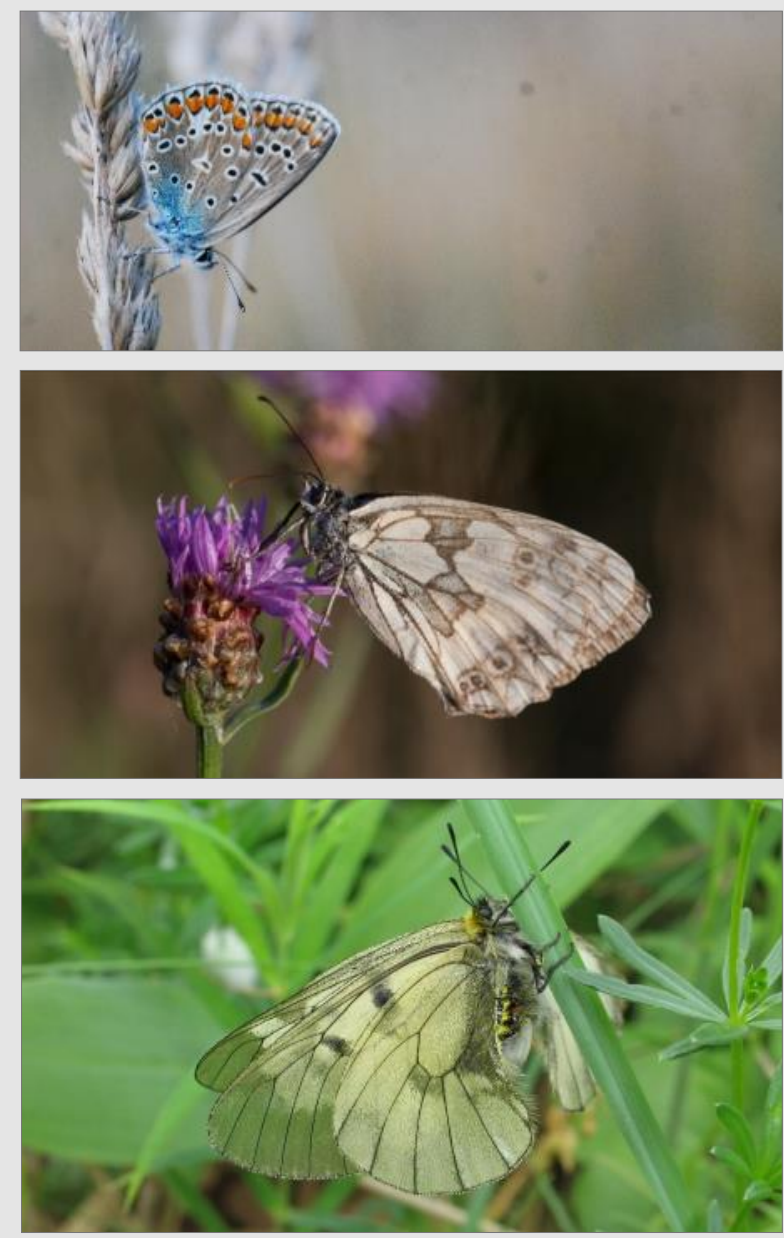

Butterflies of the mineral islands include more common species, such as Polyommatus icarus (top) and Melanargia galathea but also rare and threatened ones like Parnassius mnemosyne (here during mating). For the last species, typical for the mineral islands, proximity of warm, sunny grassland patches and oak-lime-hornbeam forests with Corydalis spp. is especially important. Photos: I. Bobrowska, J. Dengler, I. Dembicz. 

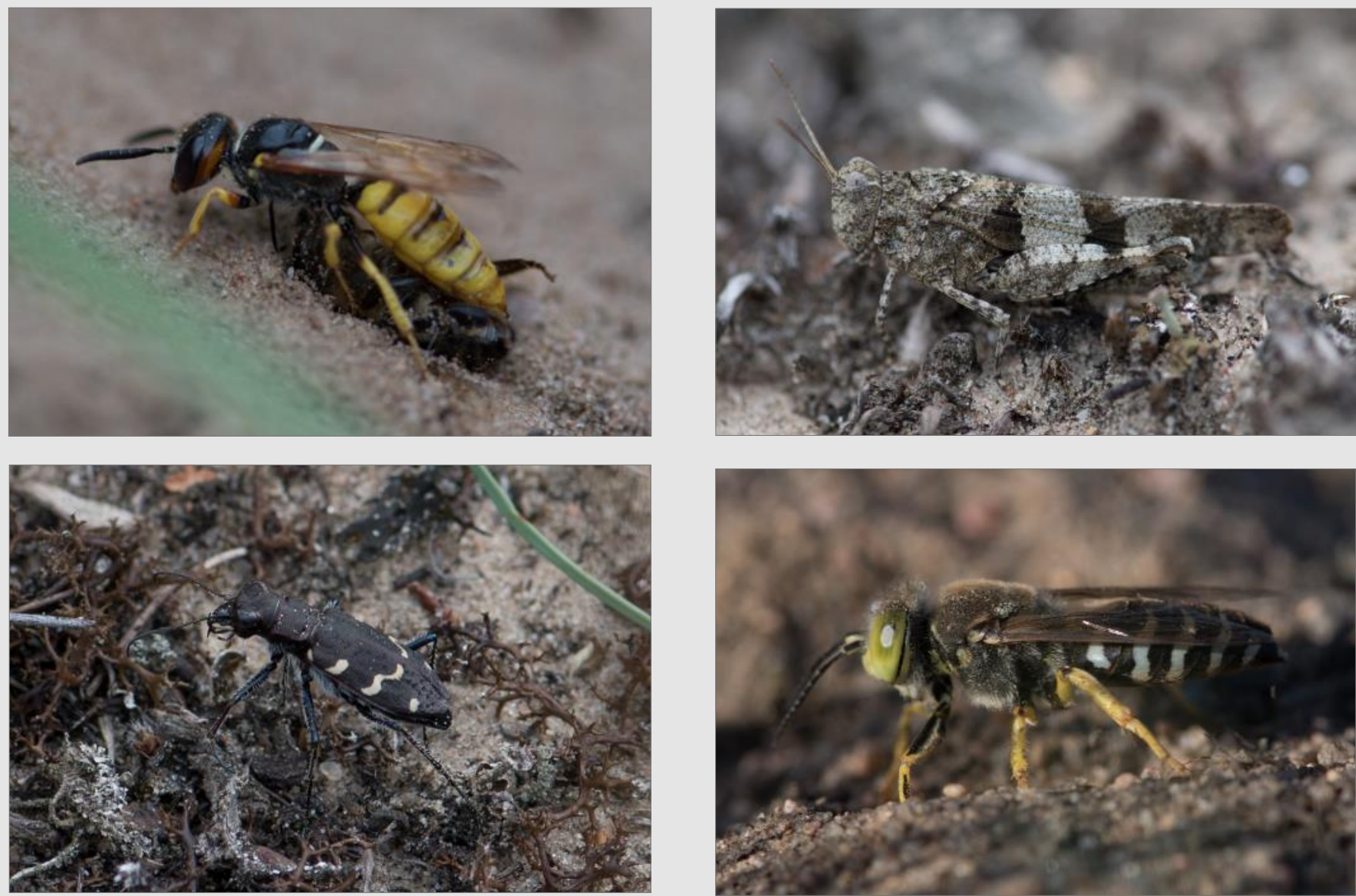

Open sandy areas are home to a specialised insect fauna: Philanthus triangulum with its prey Apis mellifera carried to the hole in the sand to feed the larvae (top left), well camouflaged Oedipoda caerulescens (top right), Cicindela silvatica running among Cetraria spp. and Cladonia spp. (bottom left), and Bembix rostrata (bottom right) - females of this species put a lot of effort in caring for their larvae and they are very faithful to its nest sites, often nesting in the same places year -on-year. Photos: J. Dengler.

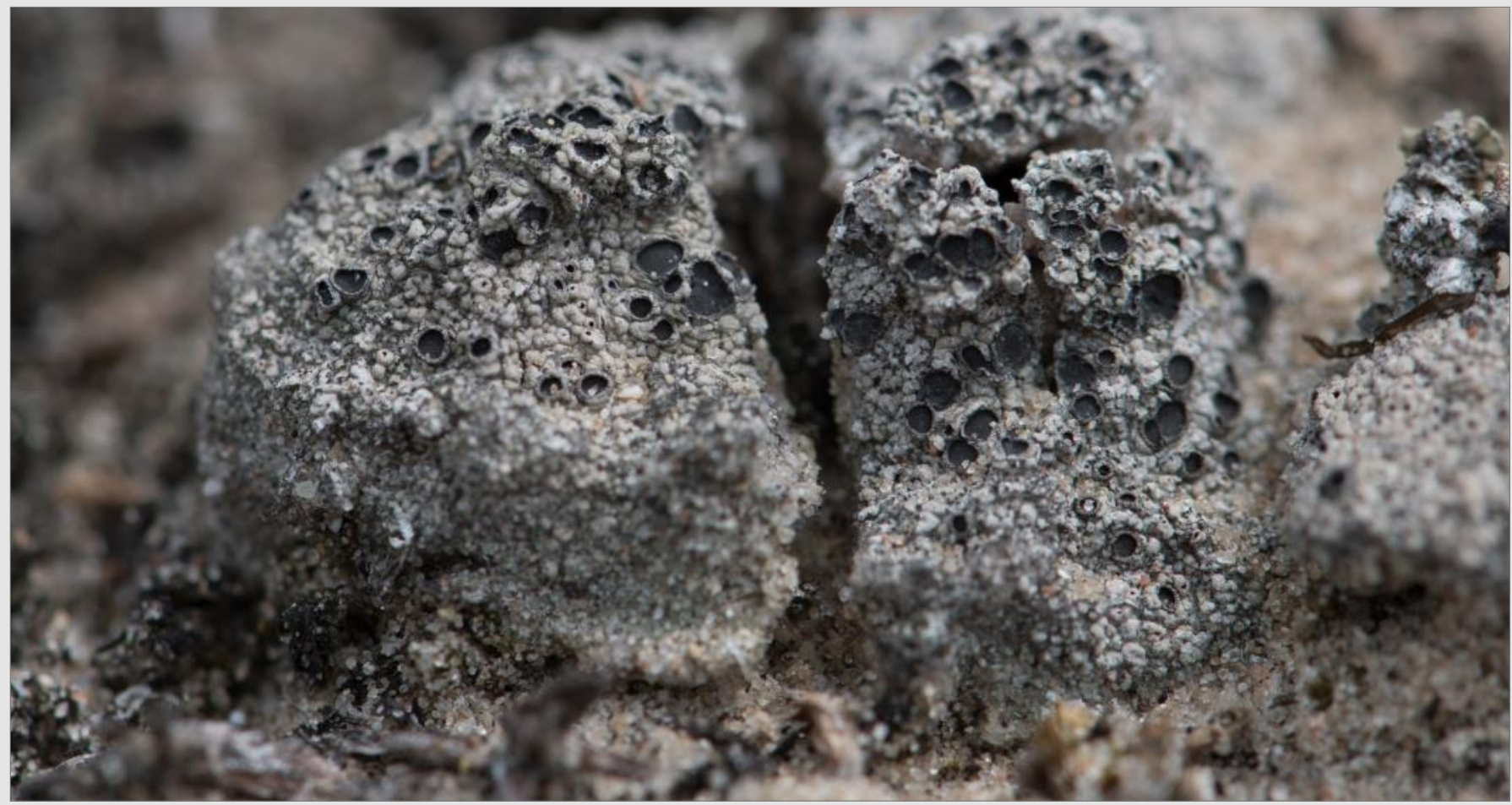

Diploschistes muscorum - lichen occurring in dry grasslands on sandy and calcium-rich soil. In early growth stages it parasites on lichens of the genus Cladonia. Photo: J. Dengler. 


\title{
New peasants: locals caring for a city meadow, and the haymaking holiday
}

\author{
Photos and text by Nadezhda Kiyatkina ${ }^{1}$, Liudmila Volkova ${ }^{2}$, Timofey Levchenko ${ }^{3}$, Nikolay Sobolev ${ }^{4}$
}

${ }^{1}$ The Cherished Meadow Project, Dm.Ulyanova st., 6-1-65, 117292, Moscow, Russia; kunape@gmail.com

${ }^{2}$ A.N. Severtsov Institute of Ecology and Evolution, Russian Academy of Sciences, Leninskiy av., 33, 119071, Moscow, Russia; Ivolkova55@yandex.ru

There are 3 hectares in Moscow, 7 kilometres away from the Kremlin, that are now known as the Cherished Meadow. This plot used to house car sheds, but after they were pulled down a few years ago, the natural growth and wildlife began to slowly take over. A discussion started among the district residents about what the place should be likewhether it should become a car park, an entertainment park, or be converted into a space sustaining biodiversity. As a result, more than 3,000 people voted in favour of creating a "refugium" for Moscow's flora and fauna on the plot. An interdisciplinary team of biologists and architects, including those from the Institutes of the Russian Academy of Science and Moscow Institute of Architecture, then proposed that the territory should have its own development project - the city's very own Cherished Meadow.

That place is cared for by the locals, as, officially, the plot is 'no-man's-land'. The city is keeping it in reserve for road widening or another use that may be required in the future. So, to prolong community interest in the meadow, the Cherished Meadow team has developed associated environmental activities, such as undertaking joint cleanups of the territory and botanical and zoological guided tours. The pinnacle of the creative approach to caring for the former barren land was a haymaking holiday that took place in the meadow this autumn.

The idea of haymaking was, on the one hand, an allusion to the harvest holiday in Rus' (the state that existed in the Eastern European territory until the late $17^{\text {th }}$ century) that used to take place in rural areas and, on the other hand, to the modern experience of some countries, such as Poland, that is actively restoring meadows in their cities. As we discovered, scythes are extensively used in Warsaw to cut the grass: the method by which the stems are kept intact and the appropriate height of certain plants is main-
${ }^{3}$ Department of collections, State Darwin Museum, 57 Vavilova st., 117292, Moscow, Russia; antimofa1@yandex.ru

${ }^{4}$ Institute of Geography, Russian Academy of Sciences, Staromonetniy lane, 29, 119017, Moscow, Russia; sobolev nikolas@igras.ru

tained. Nevertheless, the grass is cut all over the meadow in mid-summer and in autumn. This helps the meadow to flower for the second time, but many insects perish - for example bumblebees that collect nectar from the flowering plants or butterflies whose caterpillars and pupa (chrysalis) normally stay in the grass until the following year.

With the Cherished Meadow, we decided to try mosaic cutting in strips of 4-5 m width and equally distanced from each other. Such a small mosaic pattern, on the one hand, prevents young trees from taking over the meadow and, on the other hand, ensures that no special habitat is removed by mowing and no overwintering insect species is lost. On this occasion, we chose an experimental plot of $100 \times 20$ meters, but in the future, the basic treatment regime will consist of mowing $30 \%$ or $50 \%$ of the meadow territory in strips, with an annual rotation of the processed area. The next summer will be the first one when we will be able to evaluate the results of the experiment.

To attract more attention to this environmental initiative, the works in the meadow were promoted as "revisiting the roots." Over 50 people answered the call posted on the Cherished Meadow Facebook page for people to come and enjoy the haymaking holiday in the meadow, to find scythes, and to wear elements of traditional Russian clothing. Two people came carrying scythes, two brought rakes, and one even provided a gigantic 36 -litre (!) samovar. The locals found professional musicians with a balalaika who sang chastushkas (a traditional type of short Russian humorous folk song with high beat frequency). Those involved also made hay dolls and commissioned professional architects to construct an enormous effigy using cut grass. A separate spot was chosen as a compost heap, and the hay was taken there when the event was drawing to a close. 


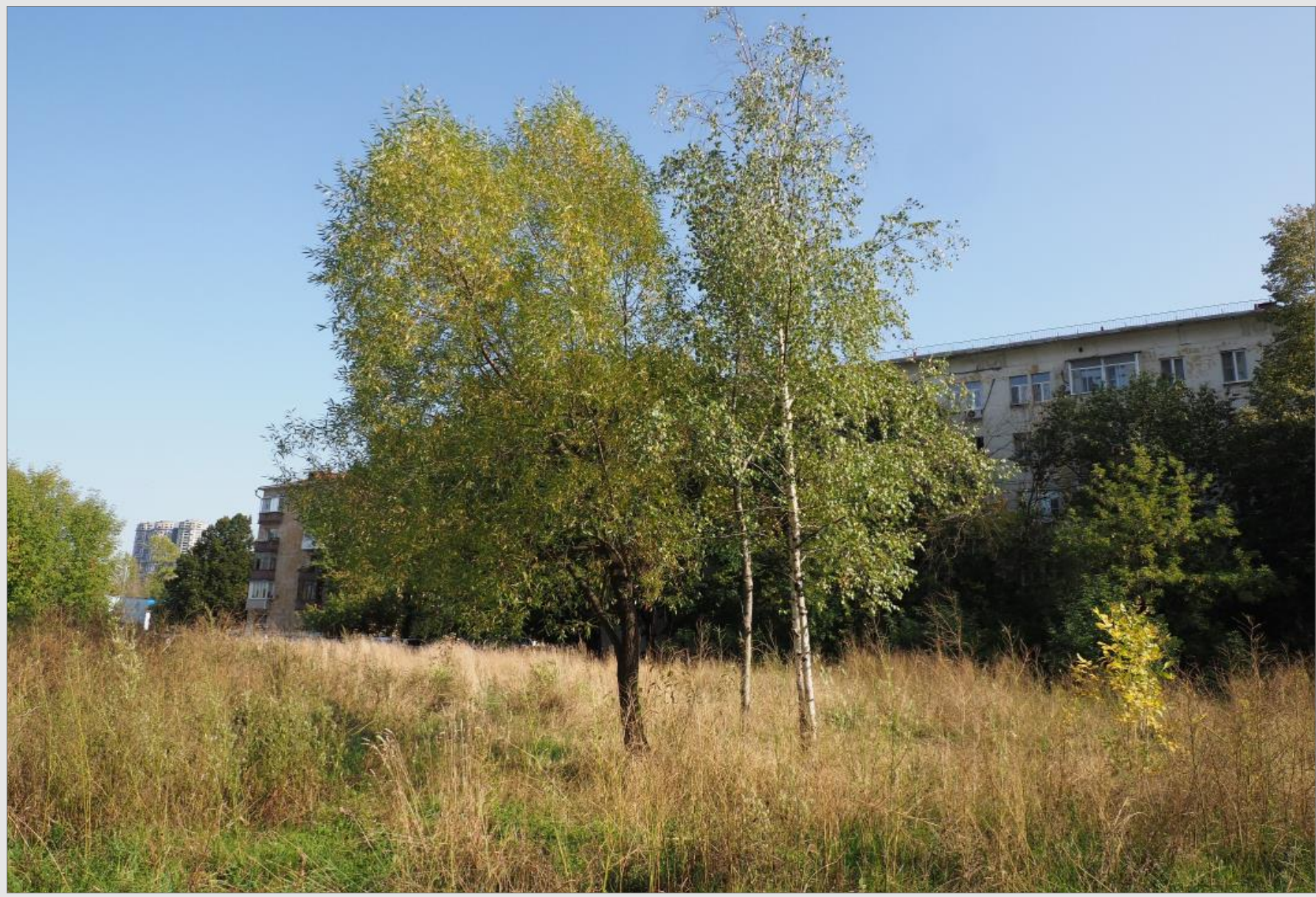

The meadow is situated not far from Moscow city centre and consists of a narrow strip of grassland between houses. September 2020. Photo: T. Levchenko.

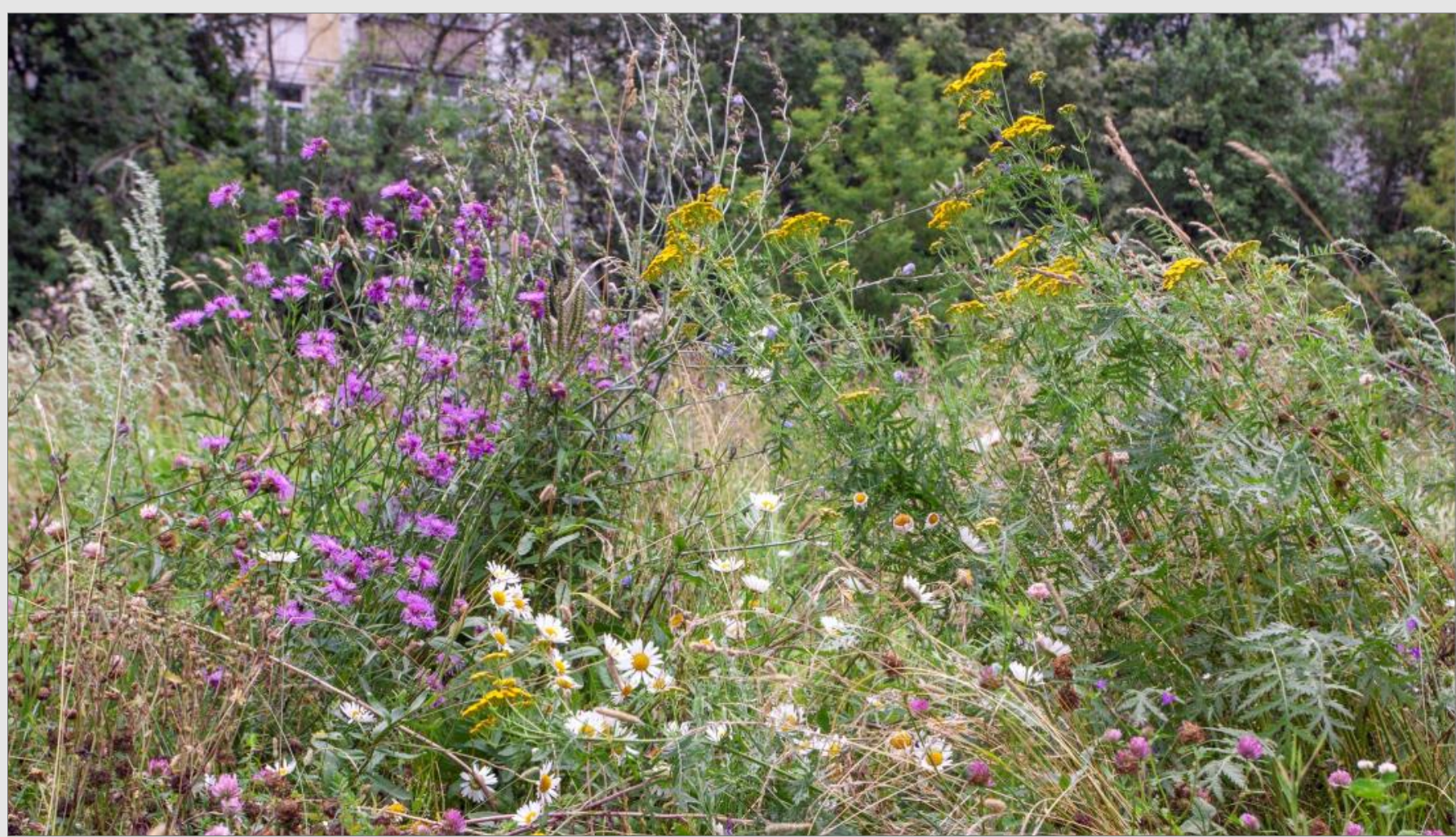

Since 2017, over 500 animal, plant, and mushroom species have been observed in the meadow. Meadow in July. Photo: A. Denisov. 


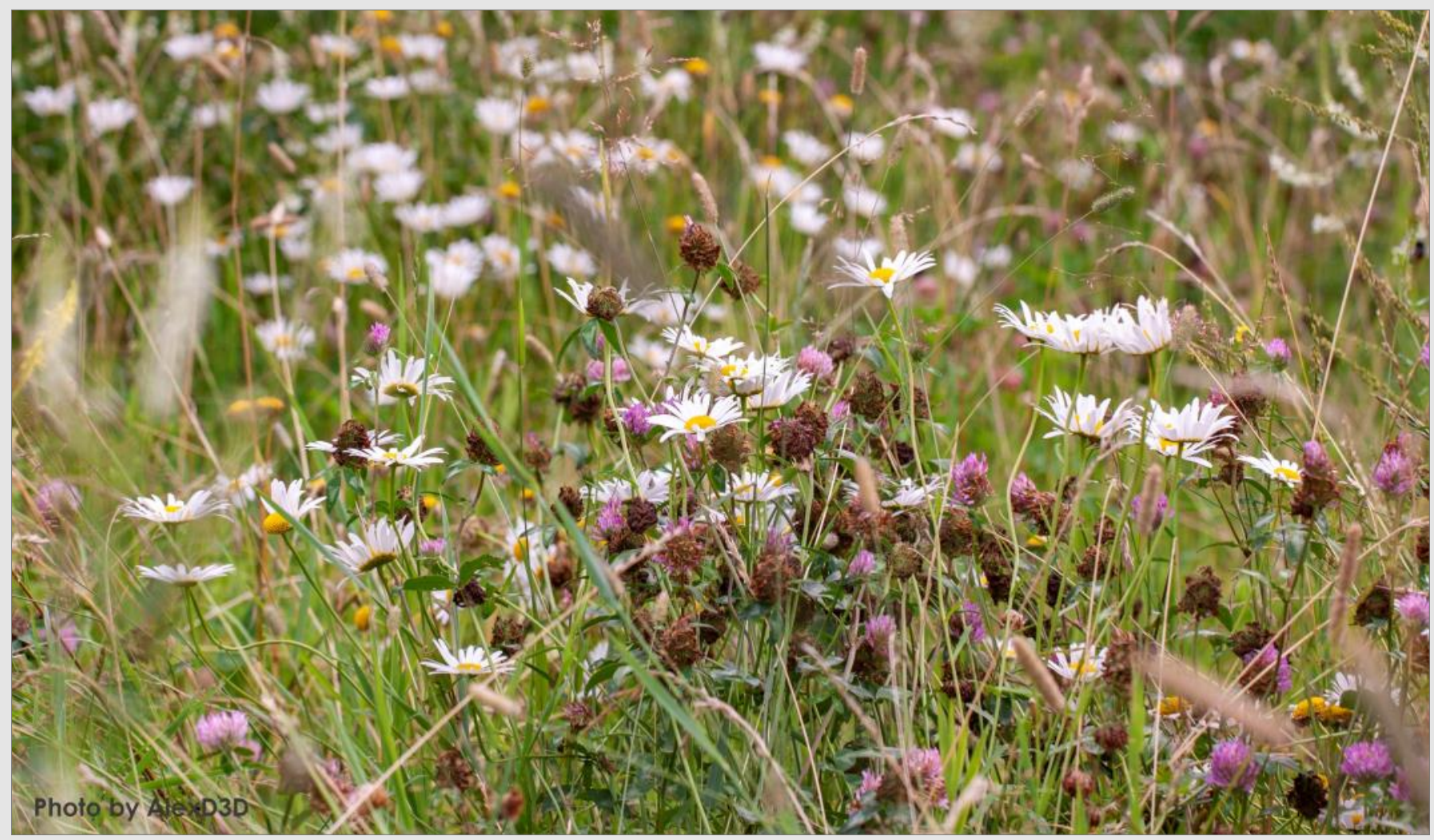

During lockdown periods, district residents were enjoying local plants more often than usual - for many, the meadow next to their house became the only opportunity to access nature. Thus, parallel paths at a social distance of 1.52.0 meters from each other, have developed within the meadow. July 2020. Photo: A. Denisov.

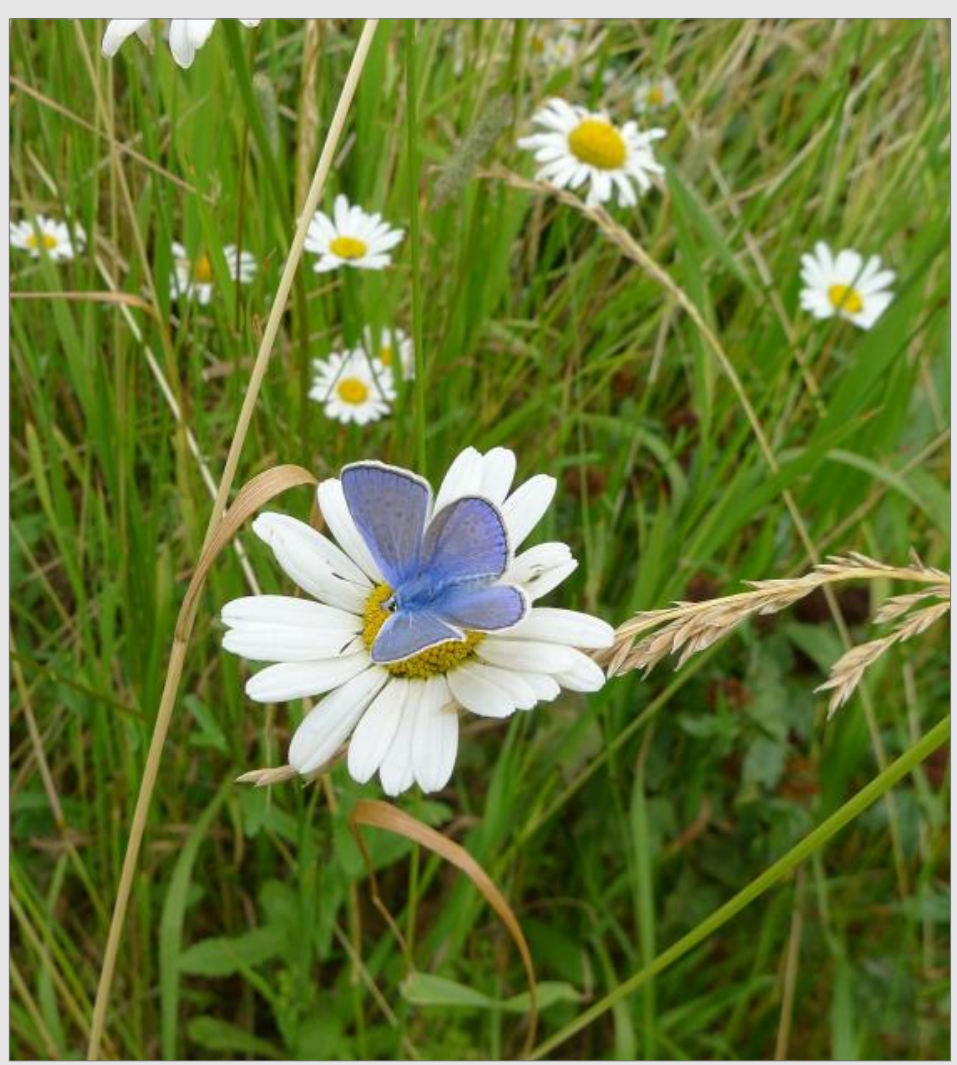

The meadow is home to over 300 animal species. The image shows a specimen of Common Blue (Polyommatus icarus). Photo: T. Levchenko.

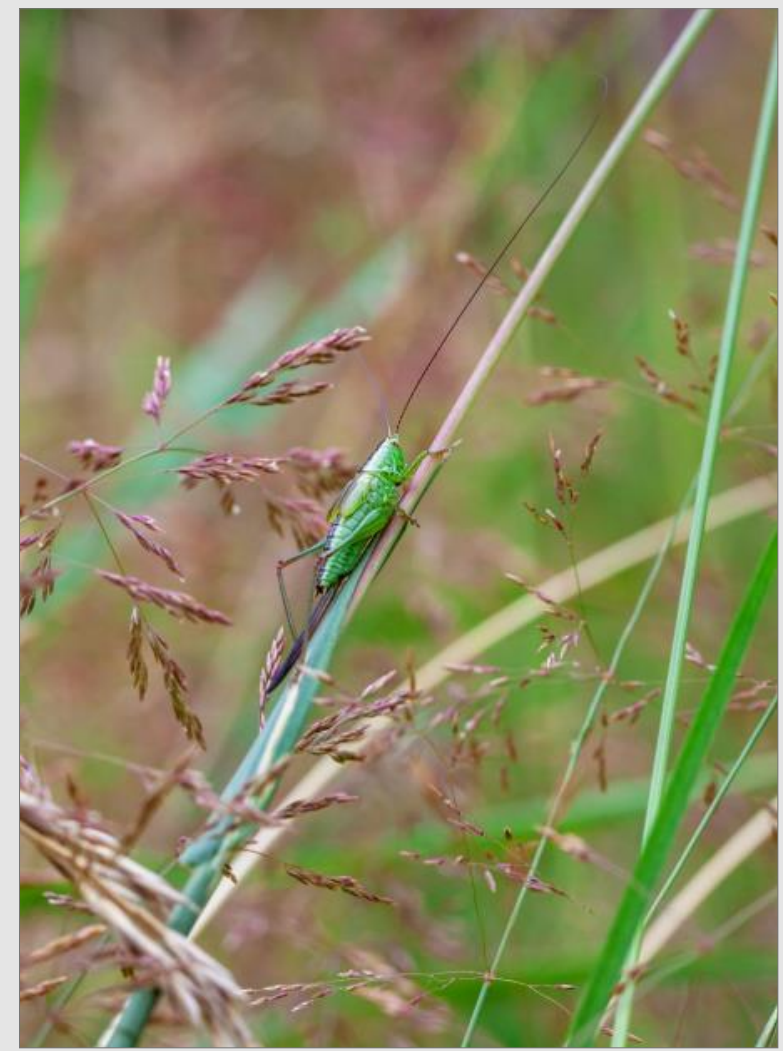

The meadow now supports 19 species from the Moscow Red List (according to the decree by the city government dated 2019). The image shows a specimen of the long-winged conehead (Conocephalus discolor). Photo: A. Denisov. 


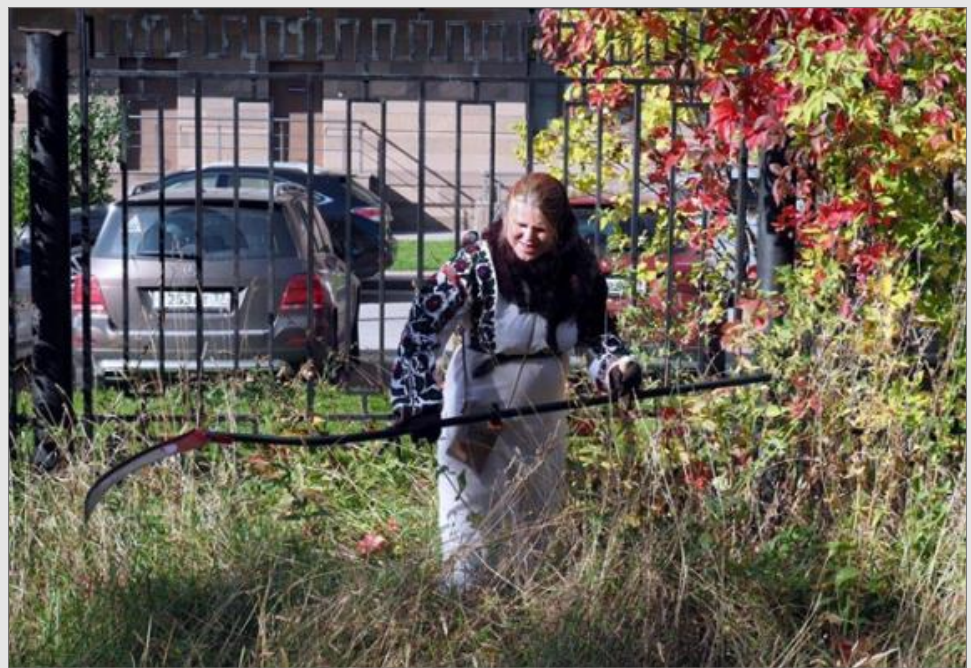

For the haymaking holiday, district residents agreed to wear traditional outfits or Russian clothing accessories. The scythe was bought in an online shop. Photo: B. Maksimov.

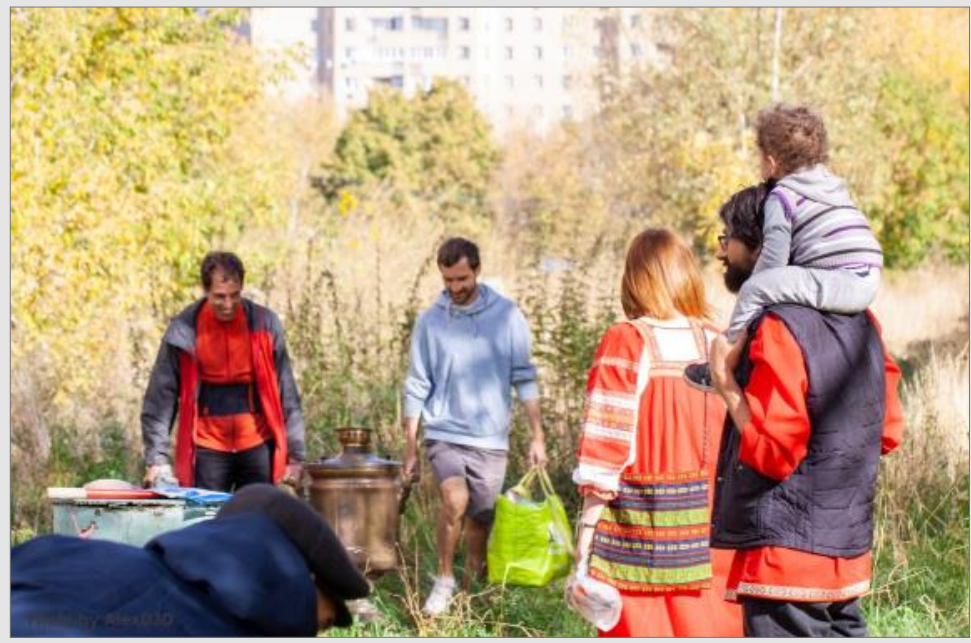

When Alexander Rappoport, the Moscow State University Botanical Garden deputy director (left), brought a samovar, the work got even merrier. Photo: A. Denisov.

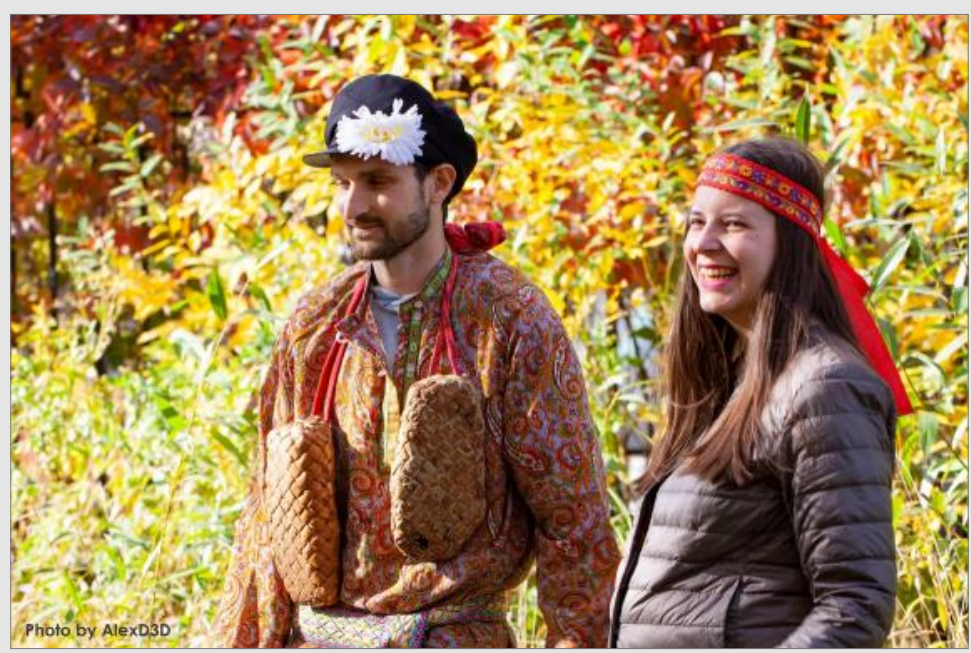

Dmitry (and birchen lapti on his neck) and Assya, local residents who have recently moved to a house nearby. Assya: "I've been longing to do something like that with my neighbours for so long!". Photo: A. Denisov.

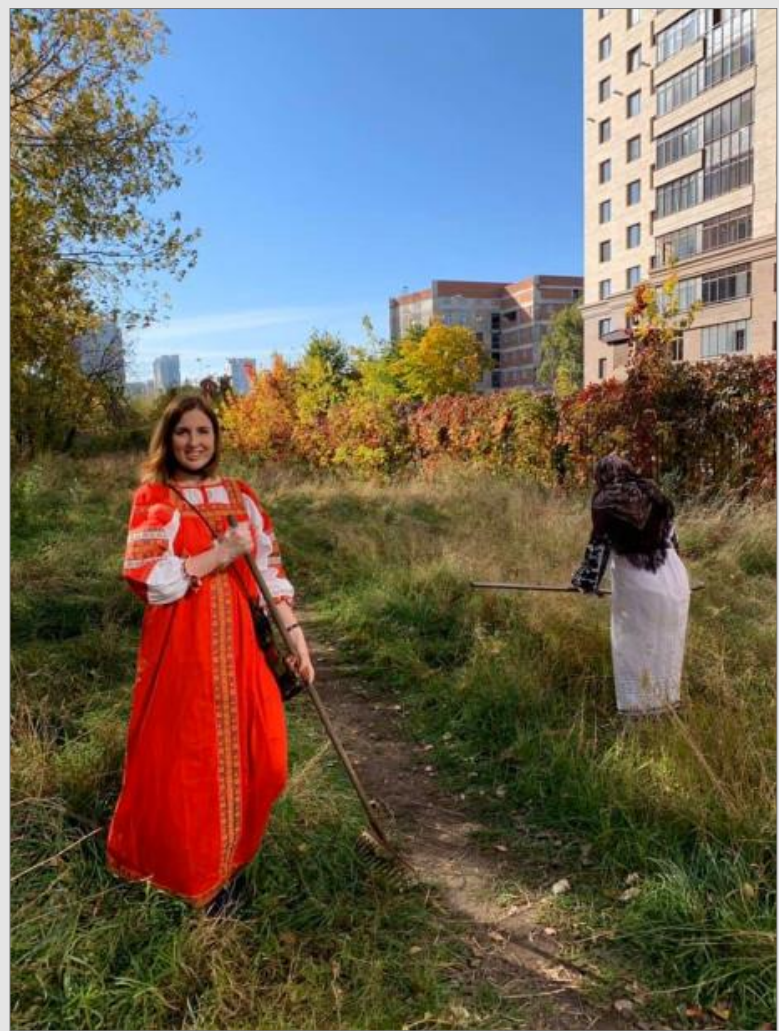

The grass-cutting was zealous and socially distanced. On the left is Nadezhda Kiyatkina, one of the haymaking holiday organizers and the Cherished Meadow project coordinator. Photo: A. Kiyatkin.

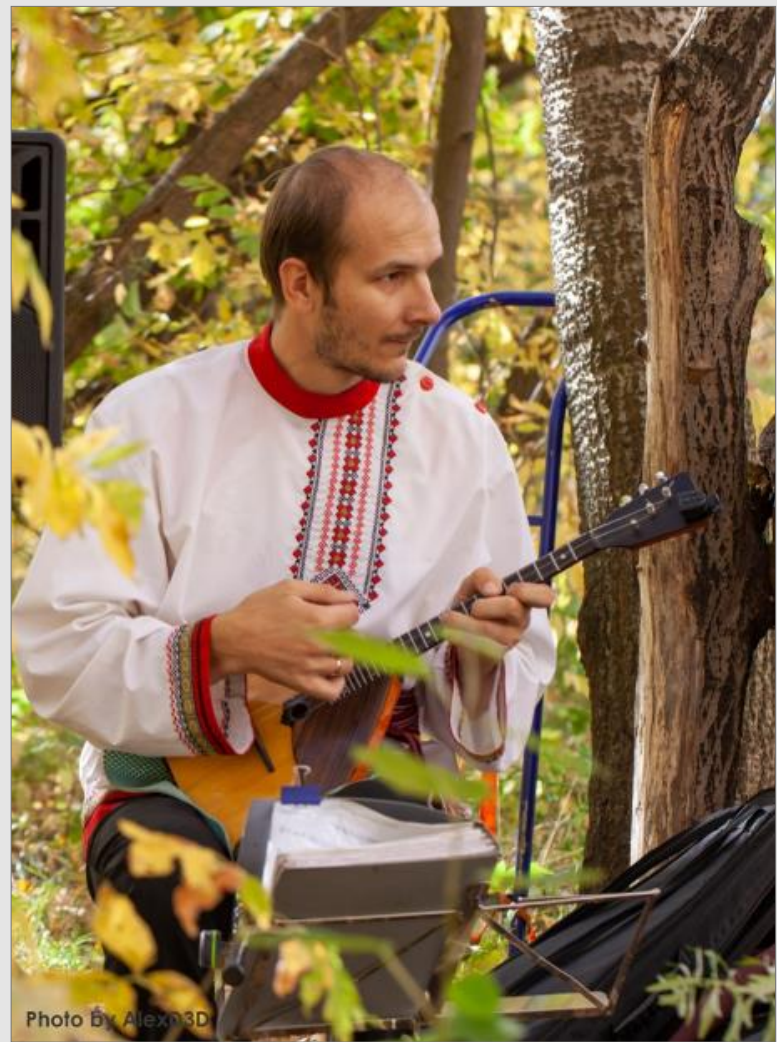

The locals found professional musicians with a balalaika who sang chastushkas. Even the Despasito song was played on that very balalaika. Photo: A. Denisov. 


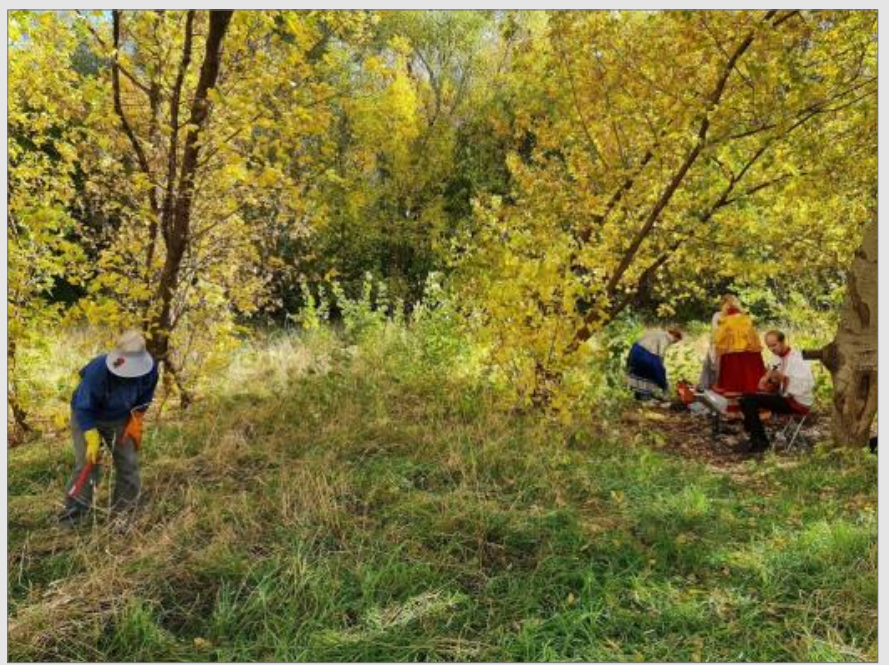

The work gets done more quickly when accompanied by a balalaika. Photo: A. Pishchalnikov.

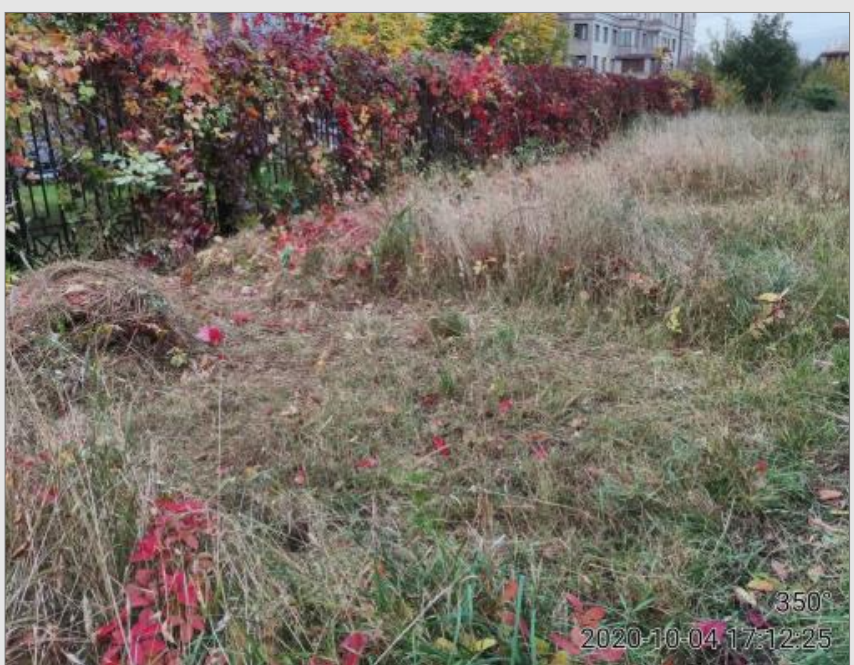

Strips of 3-4 meters were left untouched. The fiveleaved ivy creeping over the meadow was removed by hand. Photo: L. Volkova.

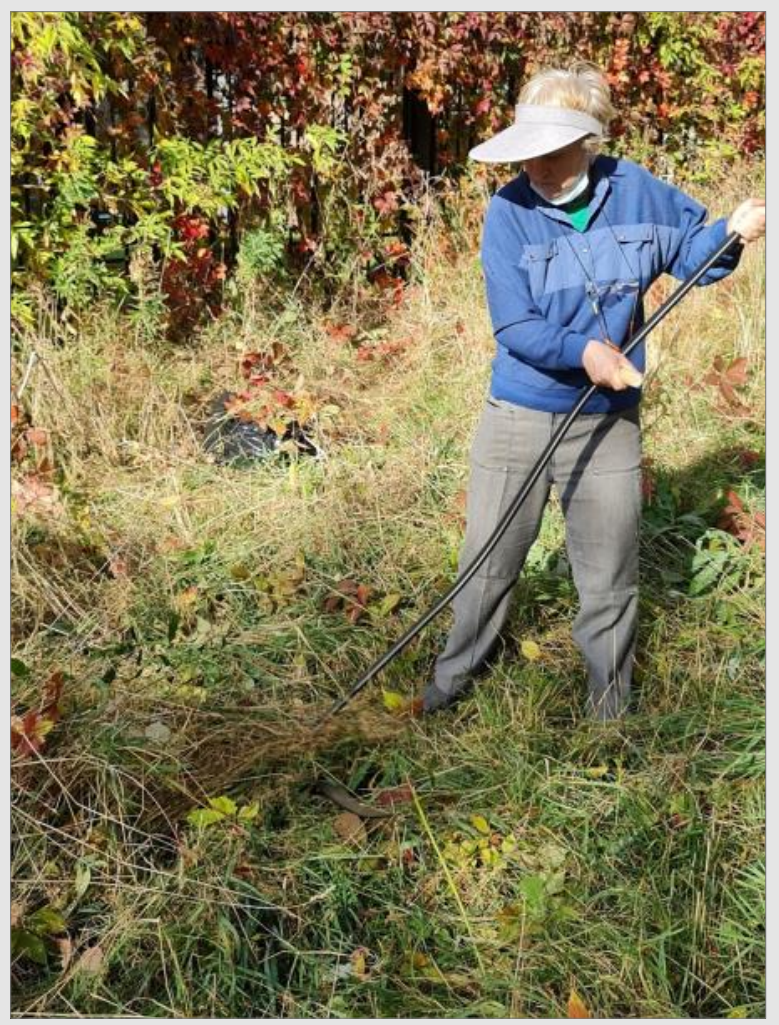

The five-leaved ivy on the fence turned out to be a real challenge for those who were cutting the grass. Tall grass concealed the amount of ivy that had managed to creep into the meadow! The cut ivy vines were arranged in a separate heap to be disposed of later. The image shows Liudmila Volkova, a scientific researcher at the Institute of Ecology and Evolution of the Russian Academy of Sciences and the Moscow Red Book editor. Photo: A. Pishchalnikov.

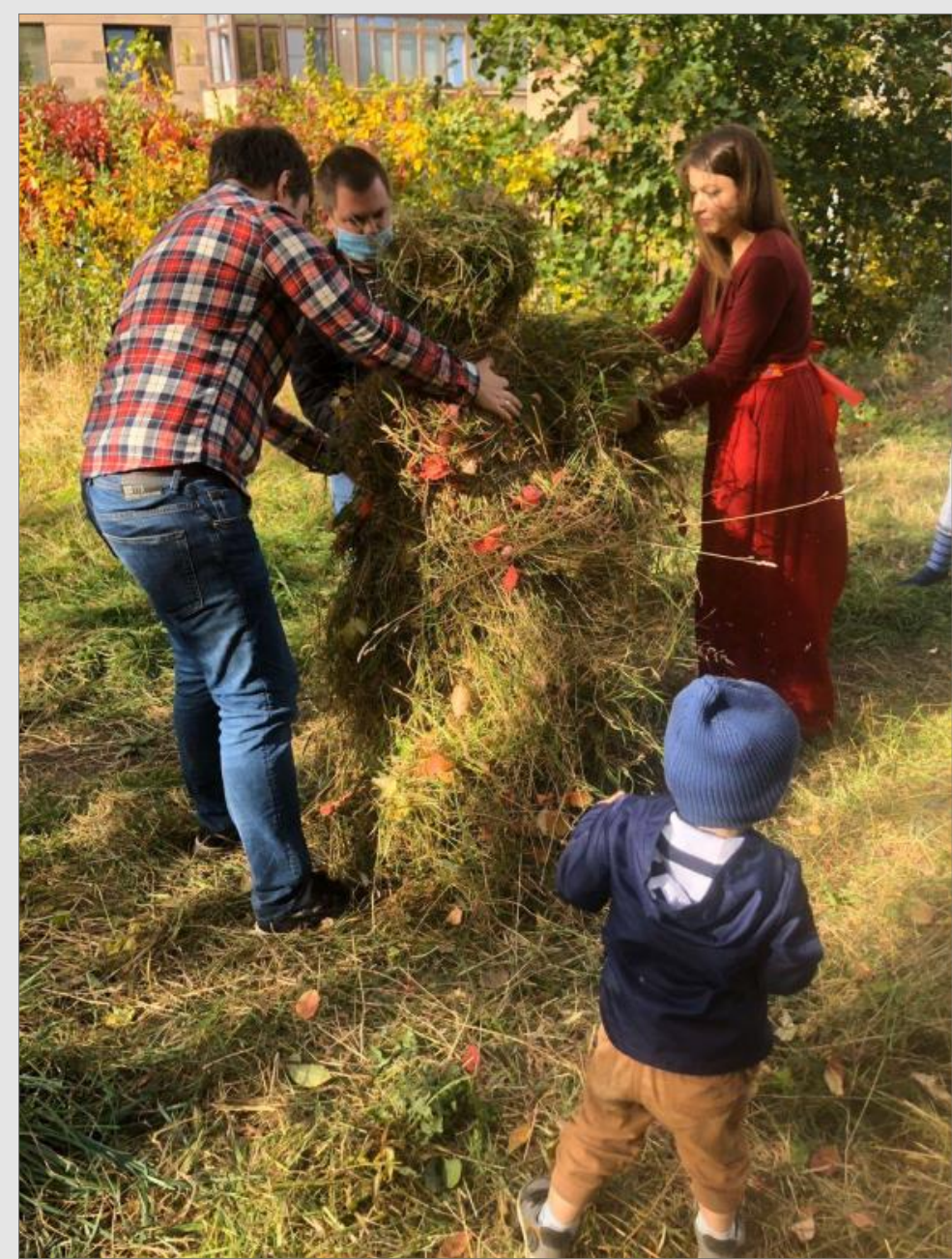

Anna Antokhina, the Cherished Meadow architect, assisted by family and neighbors, is using hay to construct an enormous effigy. Photo: N. Kiyatkina. 


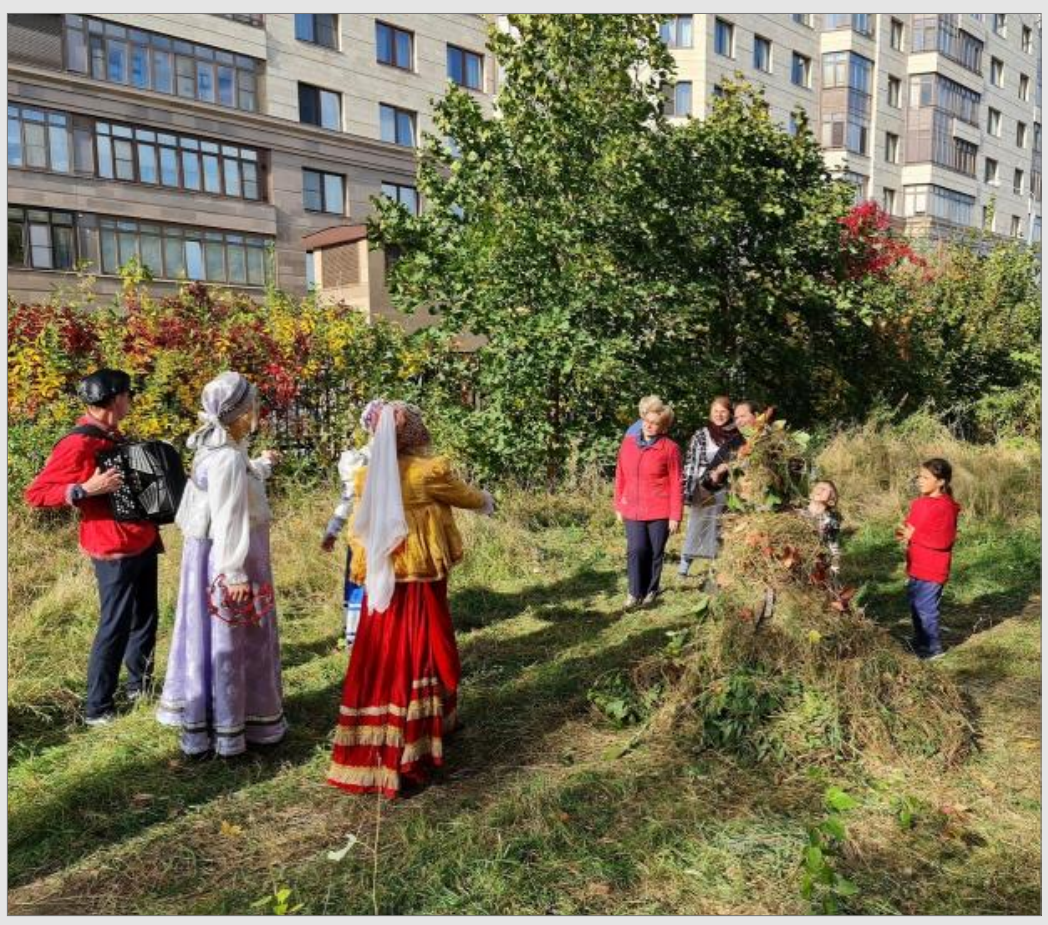

A gaily decorated festival hay centerpiece amongst those celebrating. Photo: A. Pishchalnikov.

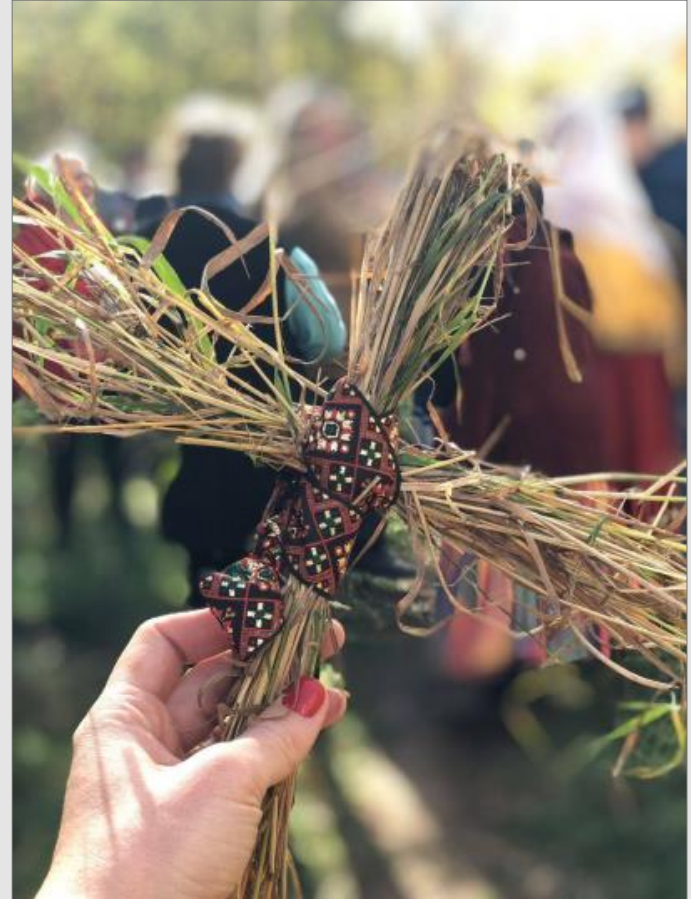

Tiny dolls can be woven with hay and decorated with lace. Photo: N. Kiyatkina.

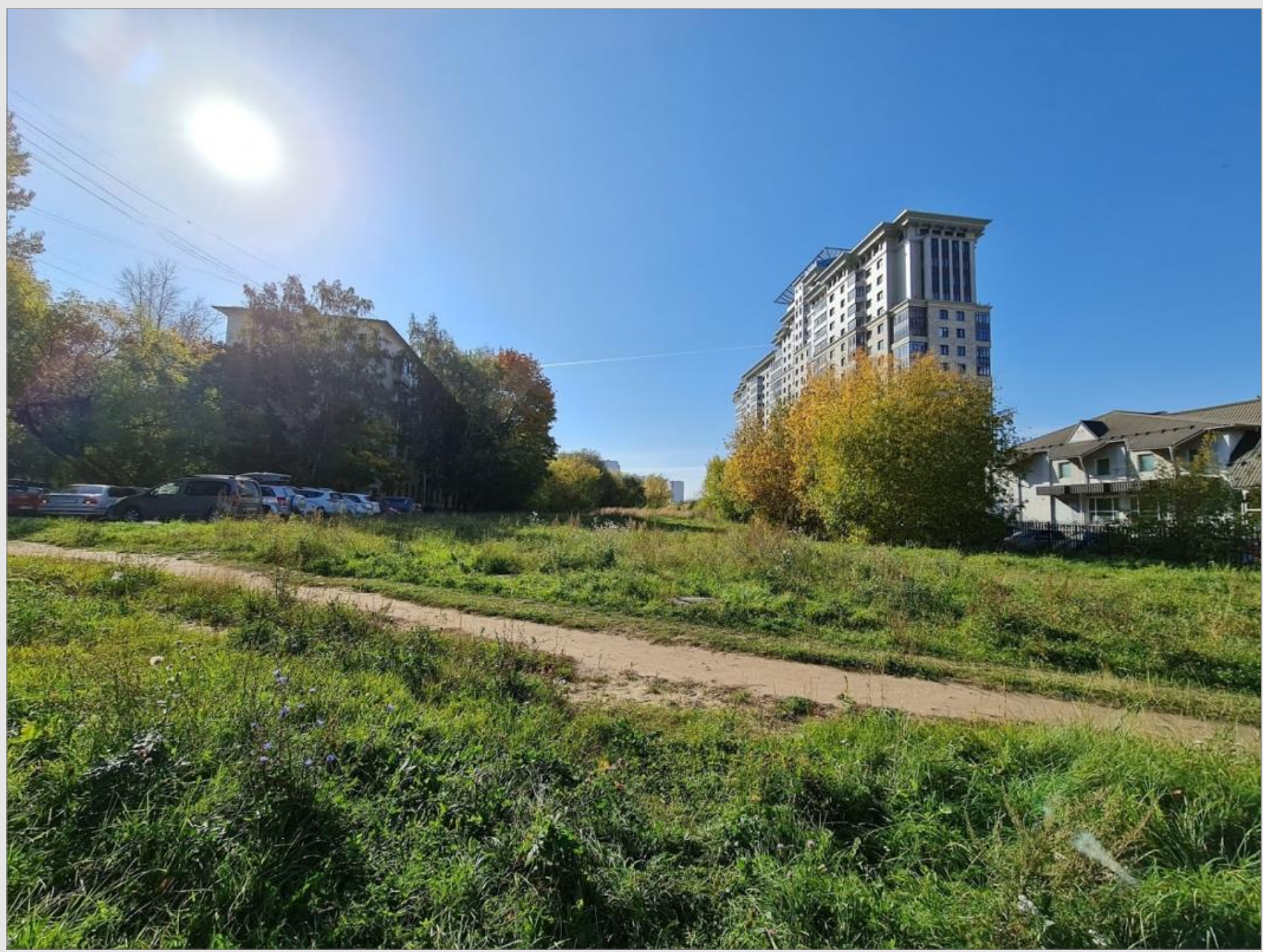

The meadow is easy to pass by unnoticed. To a stranger's eye, it is nothing more than a small overgrown strip of land, and passers-by don't realise how much fun (and beauty) they are missing. Photo: A. Pishchalnikov. 


\title{
Photo Story
}

DOI: $10.21570 / E D G G . P G .47 .58-62$

\section{Wild bees in the Cherished Meadow, Moscow, Russia}

\author{
Photos and text by Timofey V. Levchenko
}

Department of collections, State Darwin Museum, 57 Vavilova st., 117292, Moscow, Russia; antimofa1@yandex.ru

The Cherished Meadow (Russian: Zapovedniy lug) is a nature site in the Akademichesky district, Moscow. It is a 3hectare (7.5-acre) strip surrounded by urban structures. More than a half of the territory is represented by wild grassland.

In line with the latest trends in Moscow's greening efforts, wild grasses are being replaced with artificial turf grass and mown lawns lacking entomophilous flowers. Some wild grasslands have also been eliminated by tree planting. So now wild grasslands in Moscow are under threat of destruction, and this is especially true of important sites along the Moskva river plain in Krylatskoe Hills, Kolomenskoe, Brateevo, and some others.

Sooner or later, the idea of conserving wild grasslands will grow, and not only in the minds of biologists. Coincidently, residents, architects, local officials, and biologists did get together in Akademichesky district in 2017. The aim of the Cherished Meadow project is to organize a public park with natural habitats in the urban environment. Architects tried to consider everyone who lives in the vicinity: people, birds, insects, and other animals. Here's a link to an inspiring story of the Cherished Meadow by Nadezhda Kiyatkina, the one who provided the spark for the project's initiation:

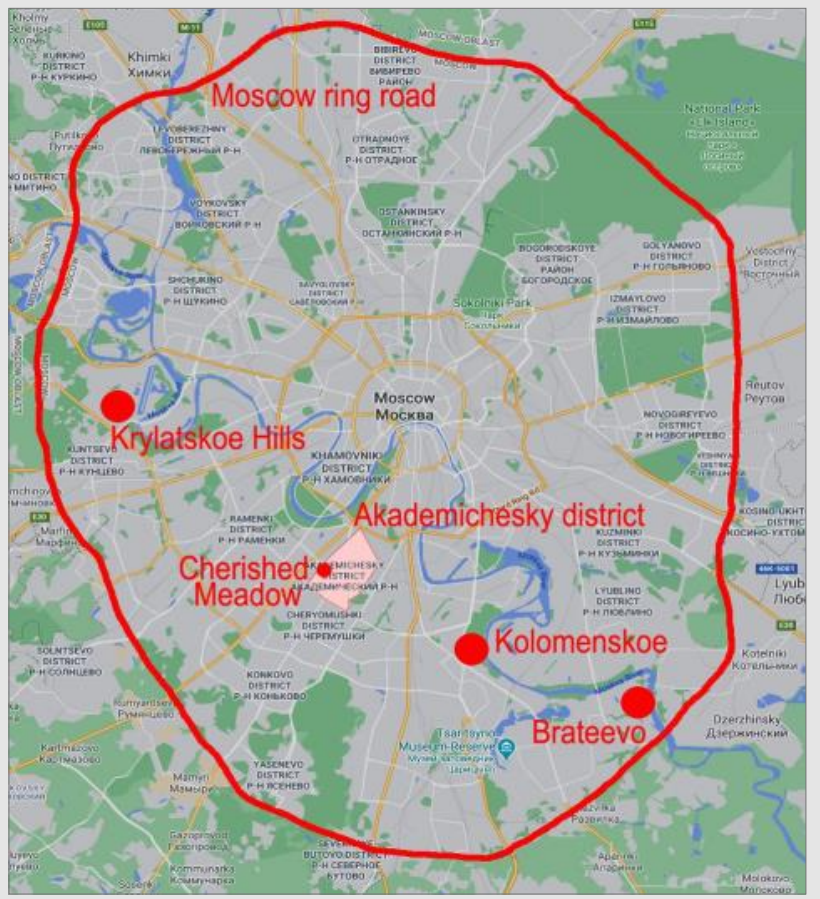

Location map of Cherished Meadow in Moscow. https://www.thenatureofcities.com/2019/11/29/inspiringdistrict-residents-specialists-and-government-officials-towork-together-to-create-a-park-that-would-sustainbiodiversity-and-meet-peoples-desires/

At present the project cannot be implemented. However, thanks to the efforts of those involved, the grassland has been saved and authorized at municipal level. It is the only official wild grassland site in the 583-hectare Akademichesky district.

More than 300 animal species, including over 60 bee species, were found in the Meadow over the period 20182020:

\section{https://www.inaturalist.org/projects/zapovednyy-lug- cherished-meadow}

This amounts to about $28 \%$ of the recently registered wild bee fauna of Moscow within the boundaries of the Moscow Ring Road. In comparison, the well-studied local bee fauna of the most valuable wild grassland in Krylatskoe Hills is twice as rich:

\section{https://www.researchgate.net/publication/338123951}

In this Photo Story, you'll meet some remarkable bee species from the Meadow.

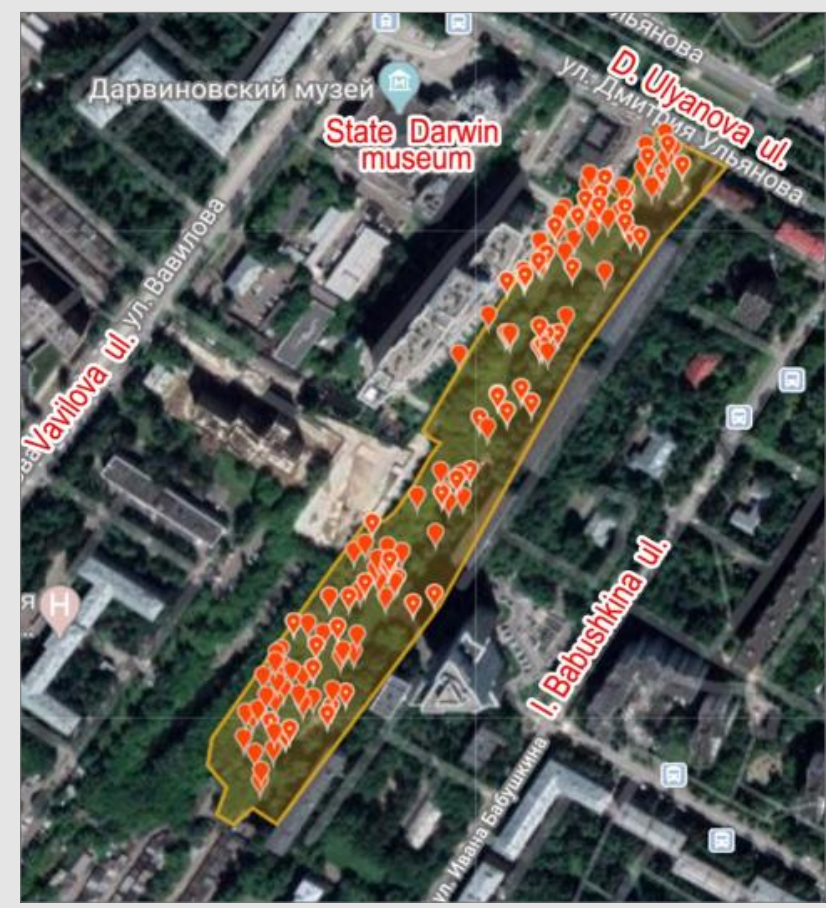

Map of observations in the Cherished Meadow (iNaturalist project). 


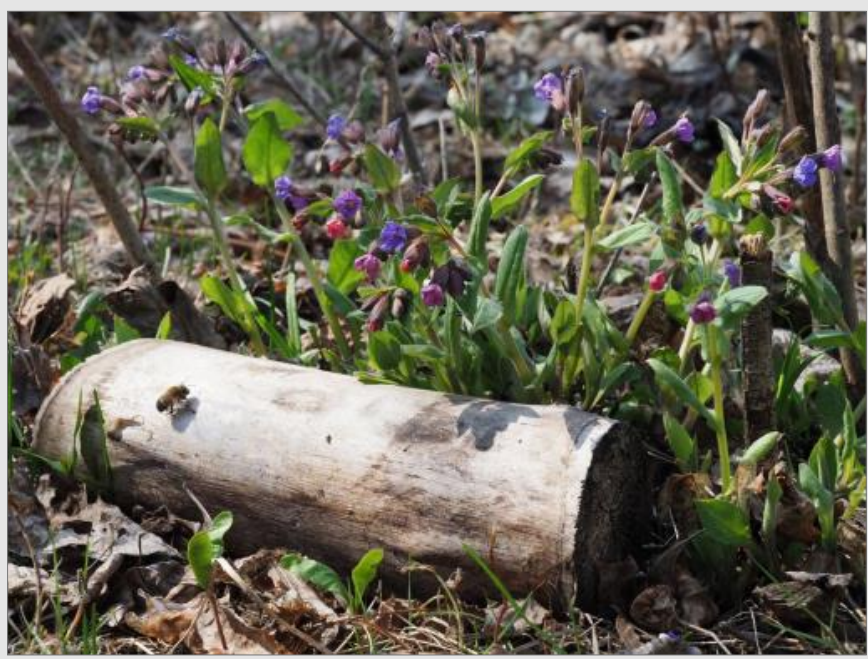

You can see wild bees during the growing season, usually from April to September. The flying season begins with first spring flowers, including Pulmonaria obscura.

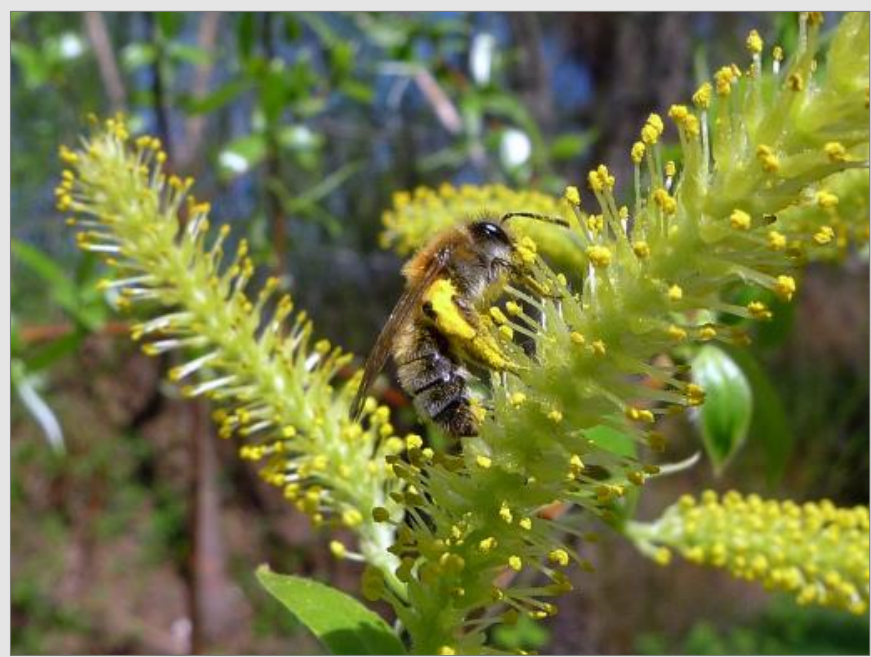

Female of Andrena praecox collecting pollen from Salix alba. This spring species feeds its larvae exclusively on pollen collected from Salix flowers.

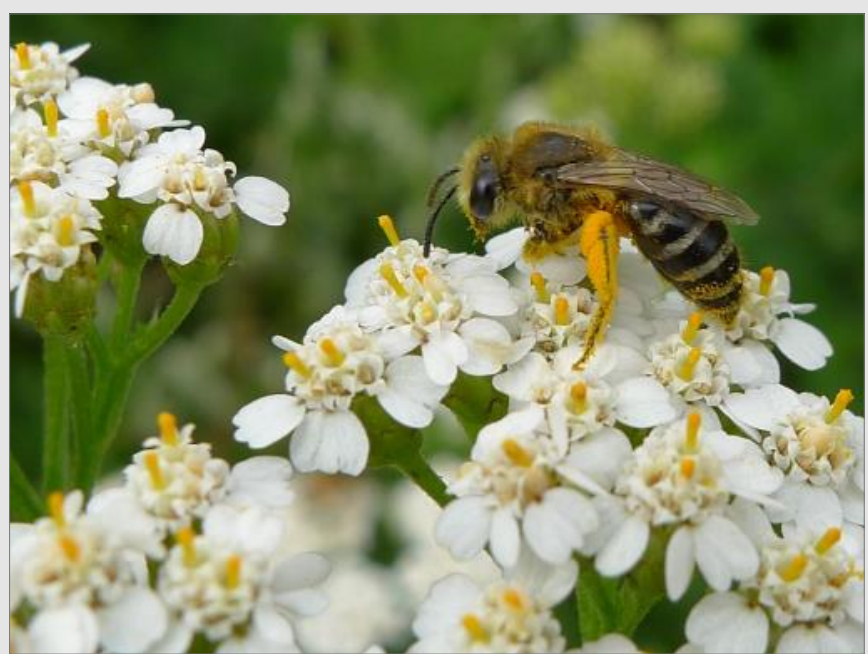

The bee species Colletes daviesanus is a specialist feeder on flowers of the family Asteraceae. This plant family accounts for about one tenth of the flora of Middle Russia. The success of the Asteraceae could be due to coevolution with many bee species.

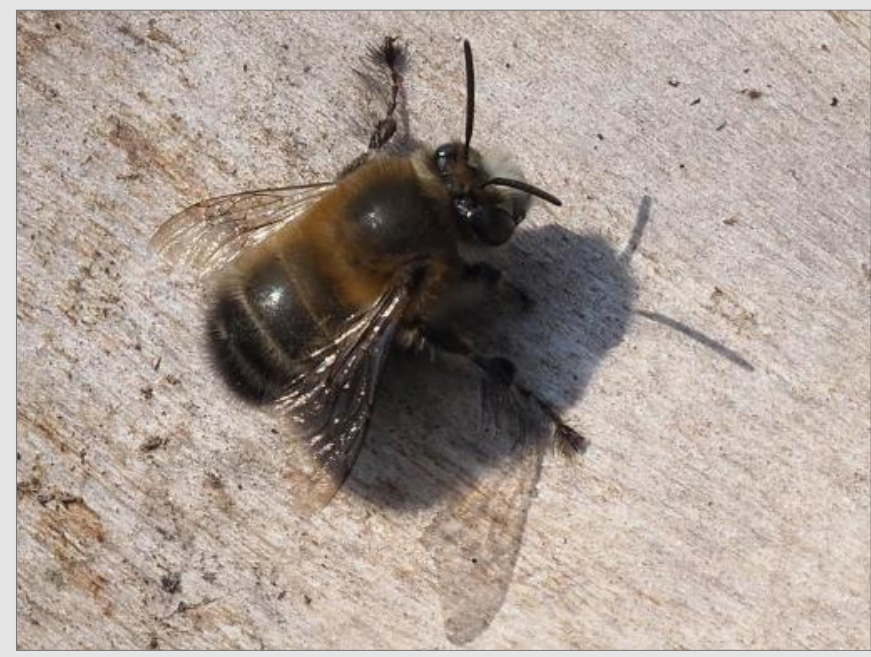

Anthophora plumipes male with remarkable middle legs is waiting for the female near some Pulmonaria. In Moscow, the species has restricted distribution range and flies for only 2-4 weeks in spring.

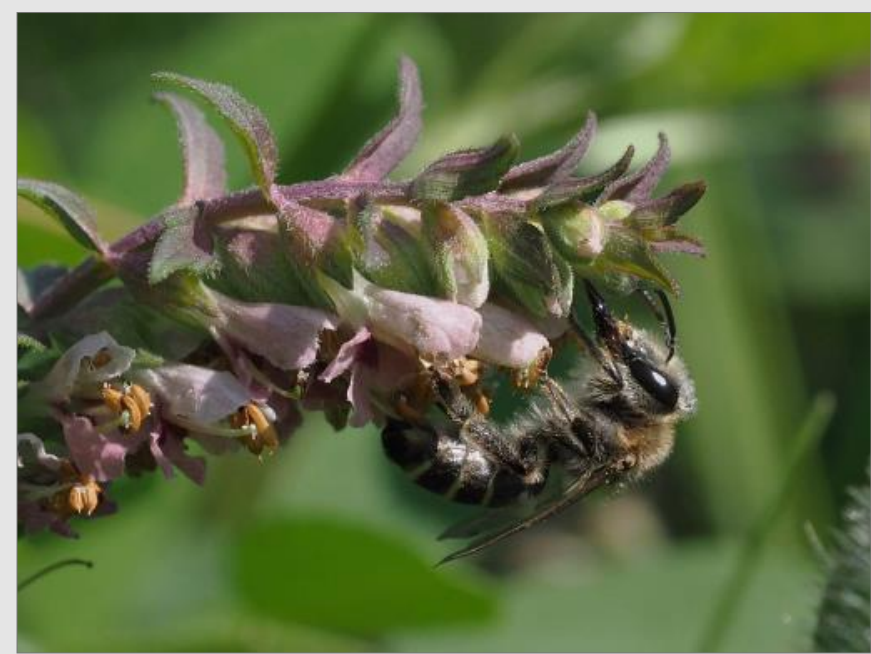

Melitta tricincta is a very special bee species. It feeds on the pollen of the semi-parasitic plant Odontites vulgaris. The bees fly during the Odontites' flowering period at the end of summer.

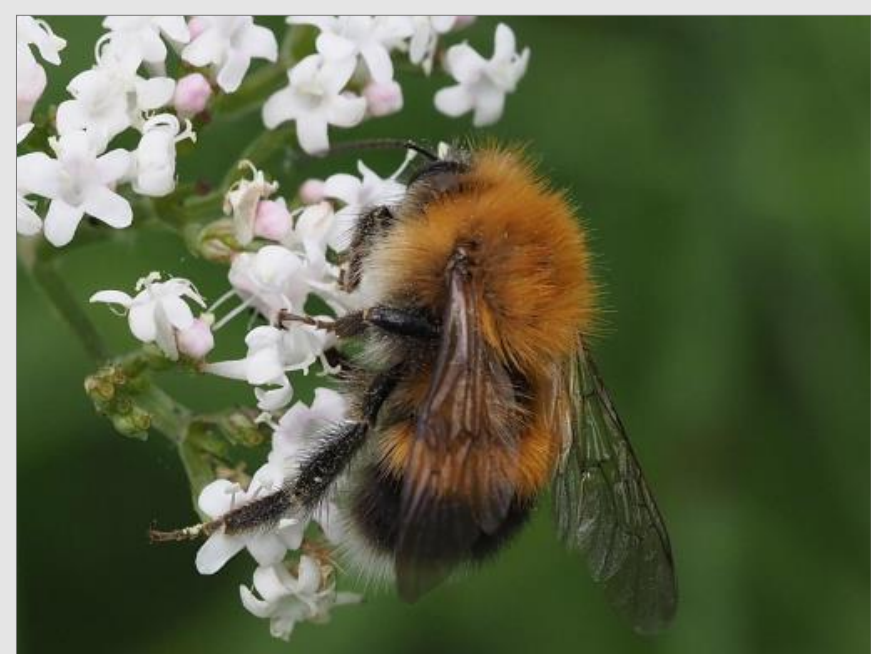

Most bees are not specialists. For example, Bombus hypnorum is a social species and flies during the whole warm season. It thus needs a constant supply of flowers providing pollen and nectar over the season. 

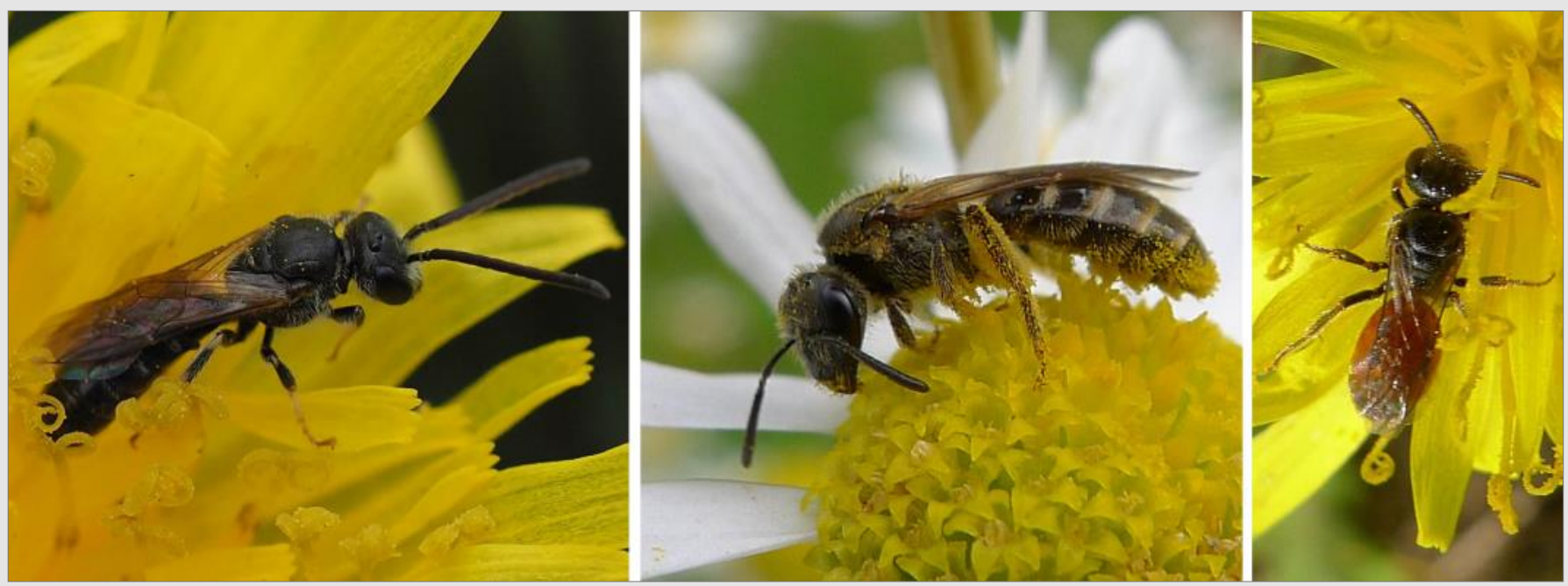

Bees exhibit distinct sexual dimorphism. The images above show a resting male of Lasioglossum pauxillum (image on the left) and a working female (image in the middle). It is a ground-nesting social species. Its colonies comprise a female queen and a few female workers. The egg cells and food provisioned by the female workers are used by cuckoo bees, Sphecodes crassus (image on the right). Cuckoo bees do not build nests of their own and can only survive if host nests are numerous.

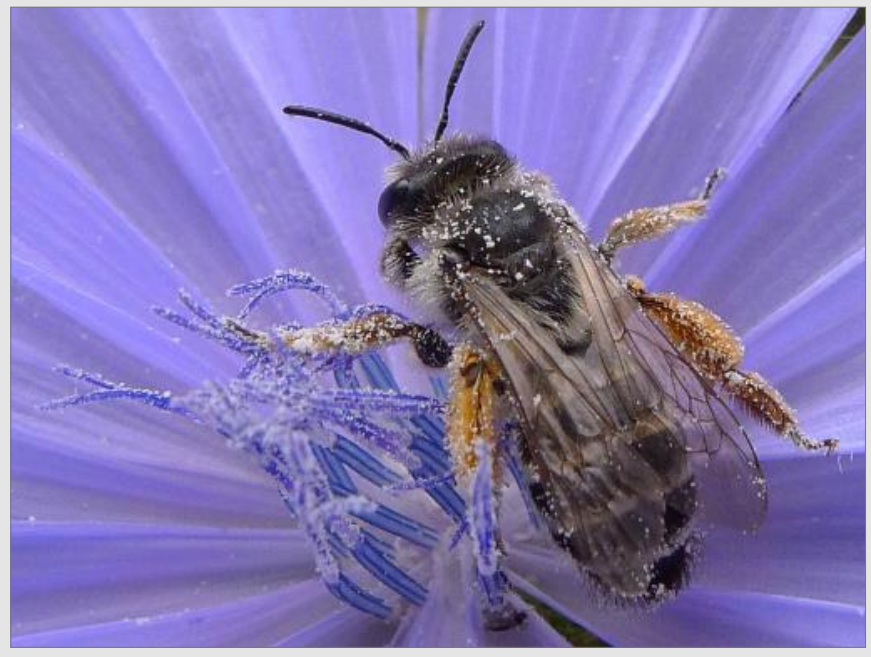

Andrena flavipes has two generations a year: early spring and mid-summer. The female in the photo is pollinating Cichorium intybus.

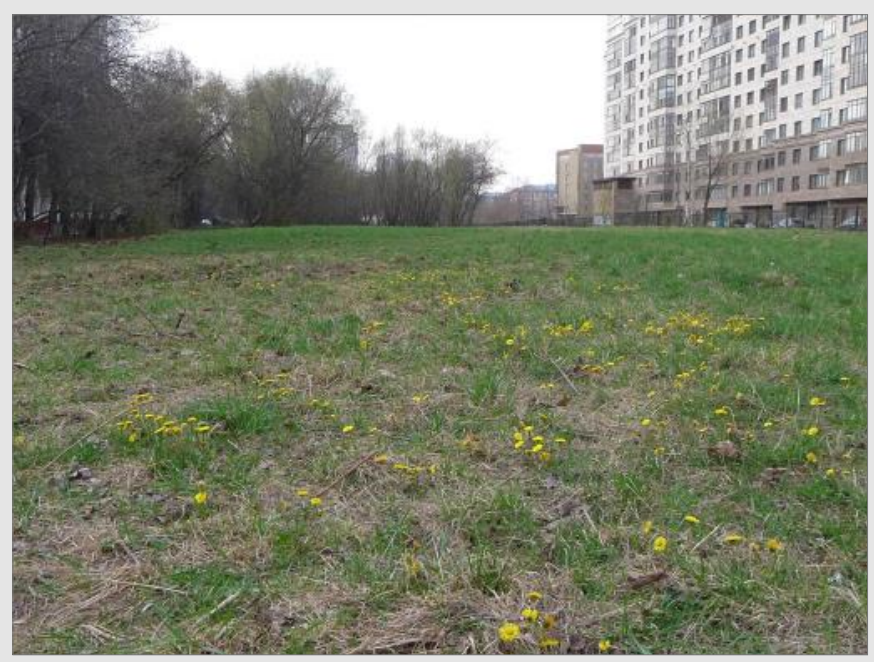

Andrena flavipes build their nests in the soil. This species can be observed in spring in the part of the meadow shown in the image above.

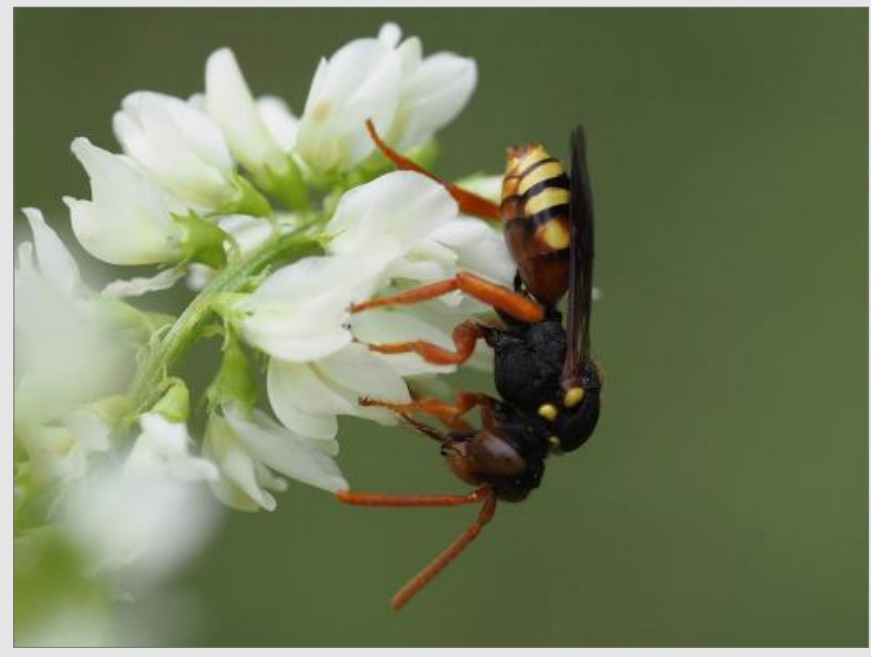

Female cuckoo bee Nomada fucata drinking nectar from Melilotus albus. The bee lays eggs in the nests of Andrena flavipe. It can also be seen twice during the warm season.

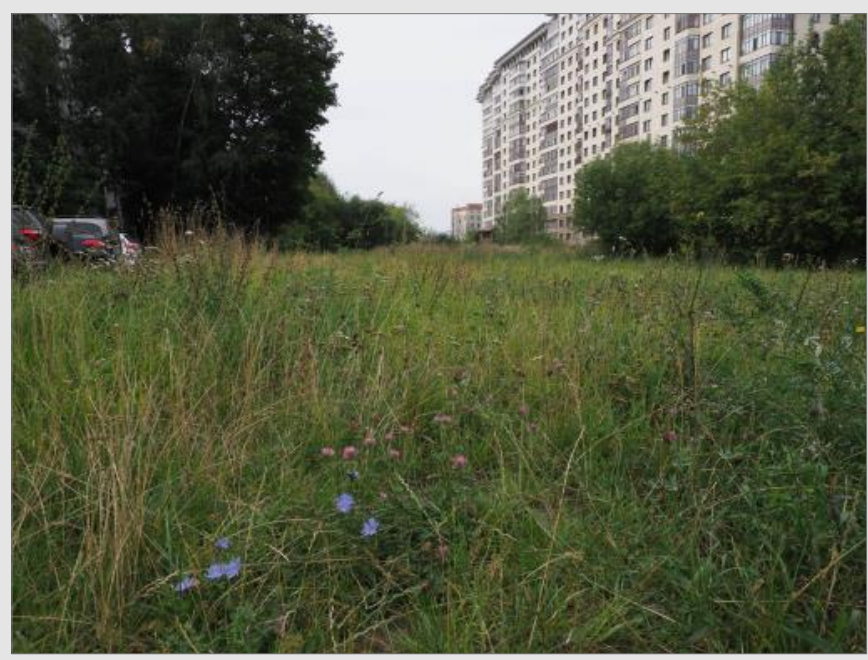

Biotope of Andrena flavipes in the late summer. At this time of year it uses other flowers. 


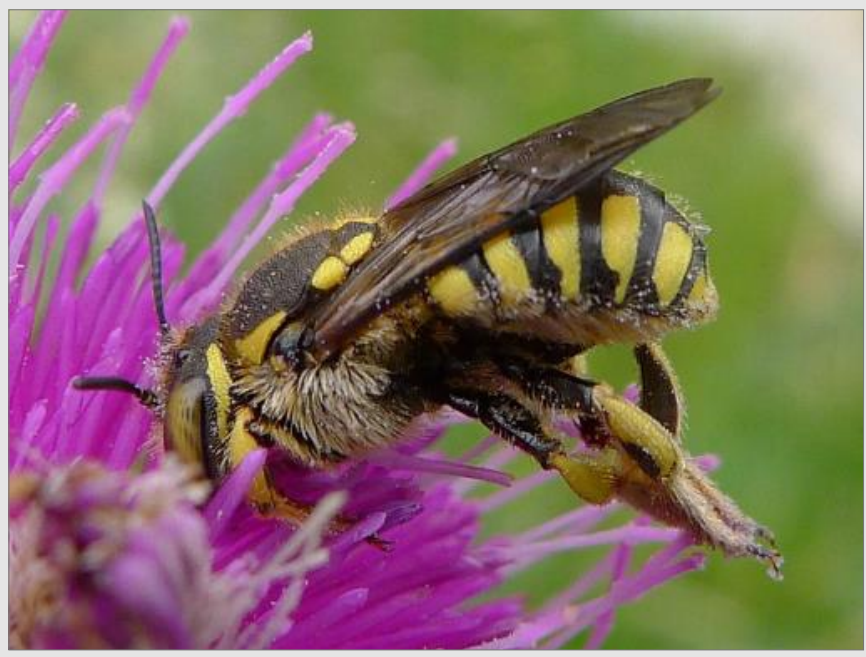

Female of Anthidium florentinum using its middle and hind legs to place pollen of Cirsium vulgaris onto its abdominal pollen brush. Females also need plant hair taken from Arctium, Leonurus and some other species to build their nest cells.

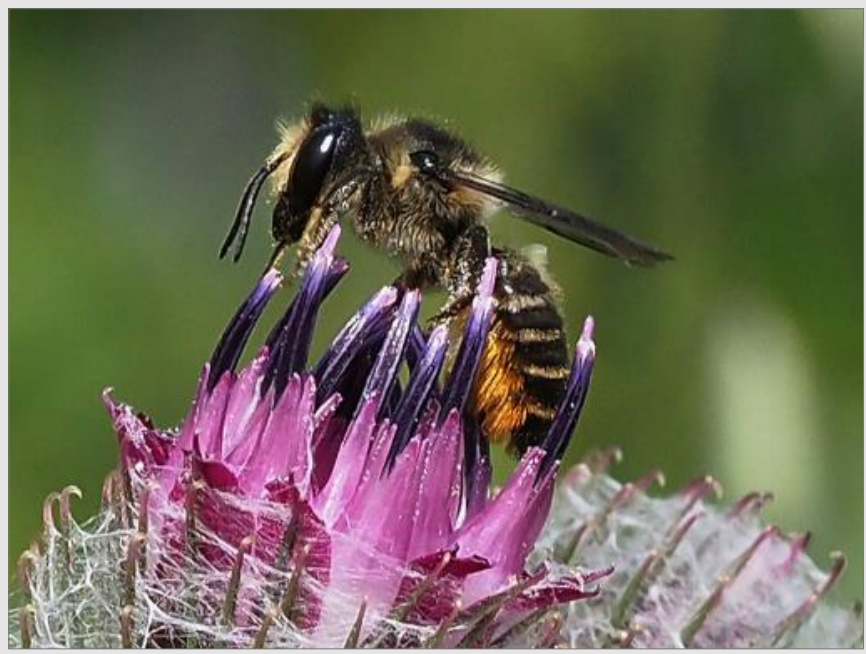

Megachile centuncularis is the most common leaf-cutter bee species in the Meadow. A female is visiting Arctium tomentosum in the image above.

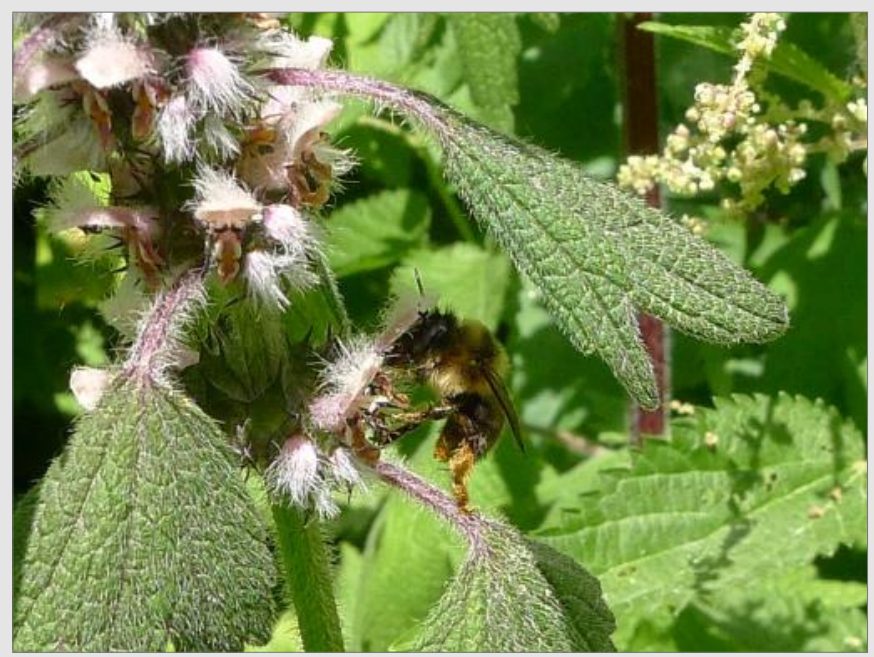

Female of Anthophora furcata visiting Leonurus quinquelobatus. This species forages for pollen in grasslands and builds nests in nearby rotten wood.

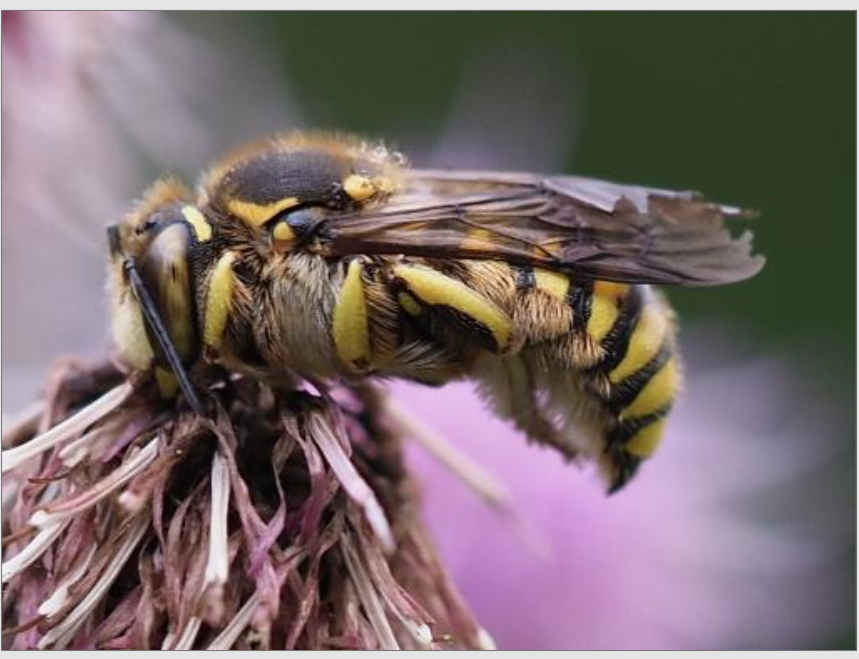

Male of Anthidium florentinum is sleeping after a hard day spent protecting its territory from other males. When male bees sleep, they only use mandibles to secure their body. Females do not allow them to sleep in the nest.

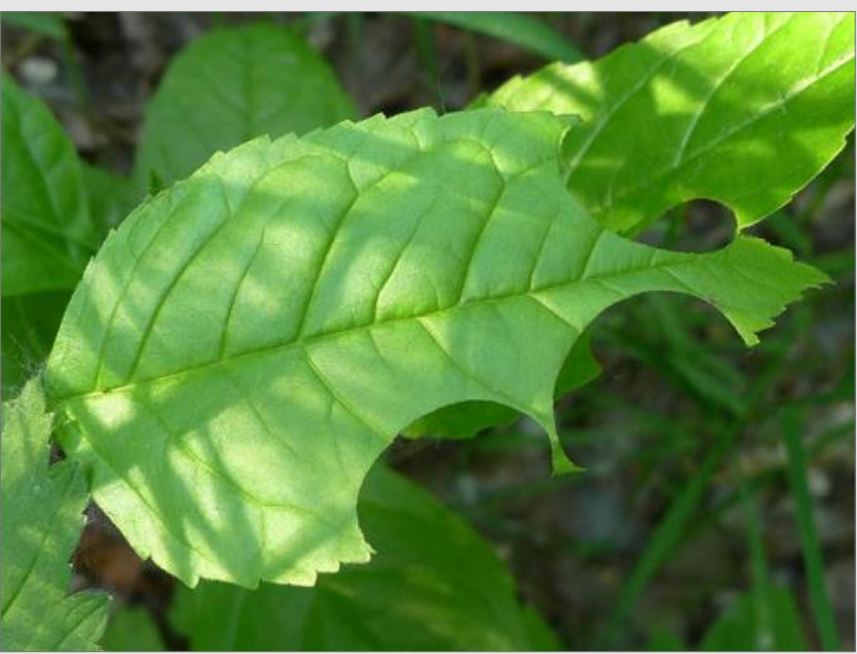

Leaf damage caused by a Megachile female's mandibles. It cuts rounded pieces of leaves to build its nest cells.

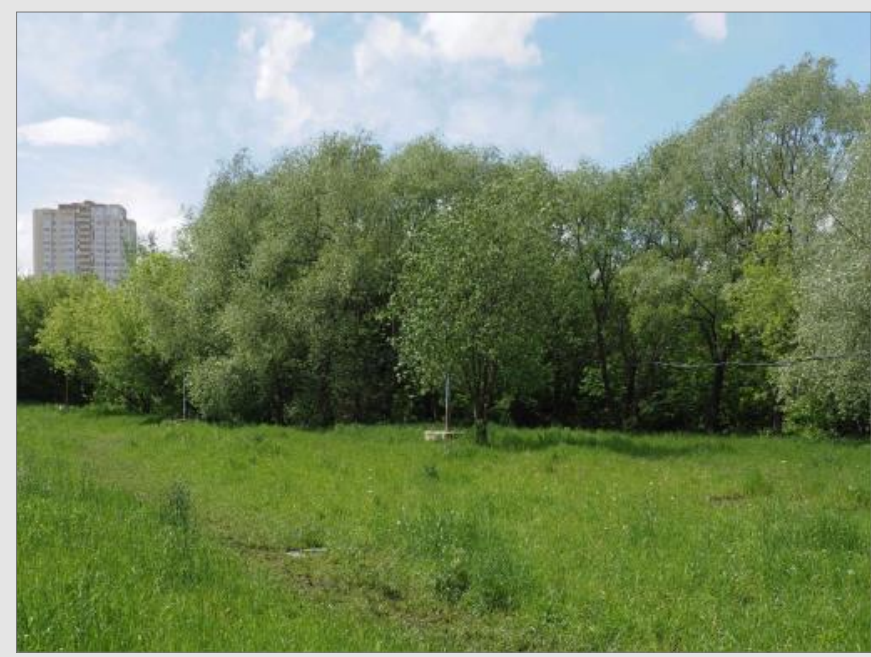

Anthophora furcata possibly uses rotten branches of Salix alba. Last summer, a female was seen near the trunks (right side of the image). 

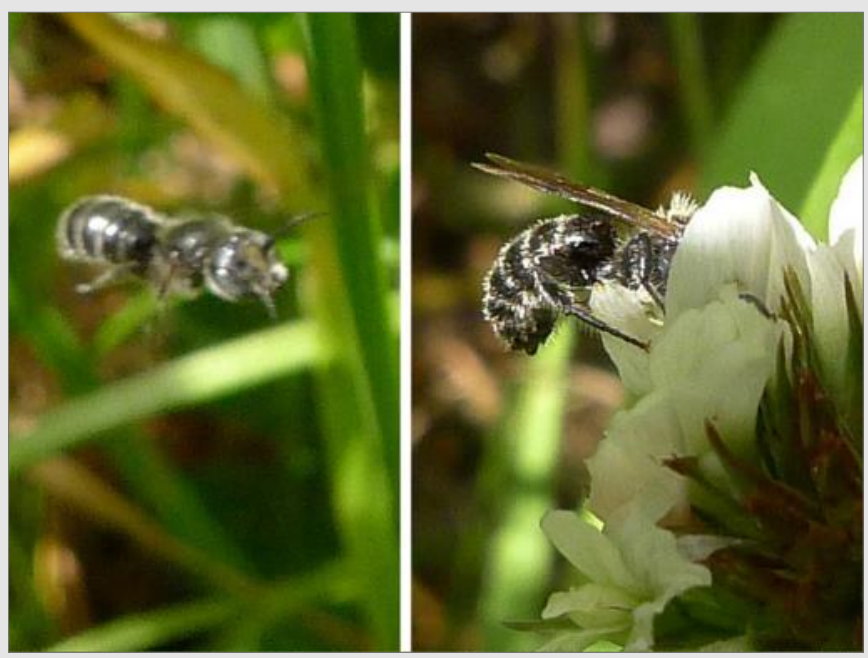

This tiny summer bee is Hoplitis leucomelaena. It builds nests in holes. It uses wood, raspberry branches and herb stems. In the Meadow, it will use Artemisia stems.

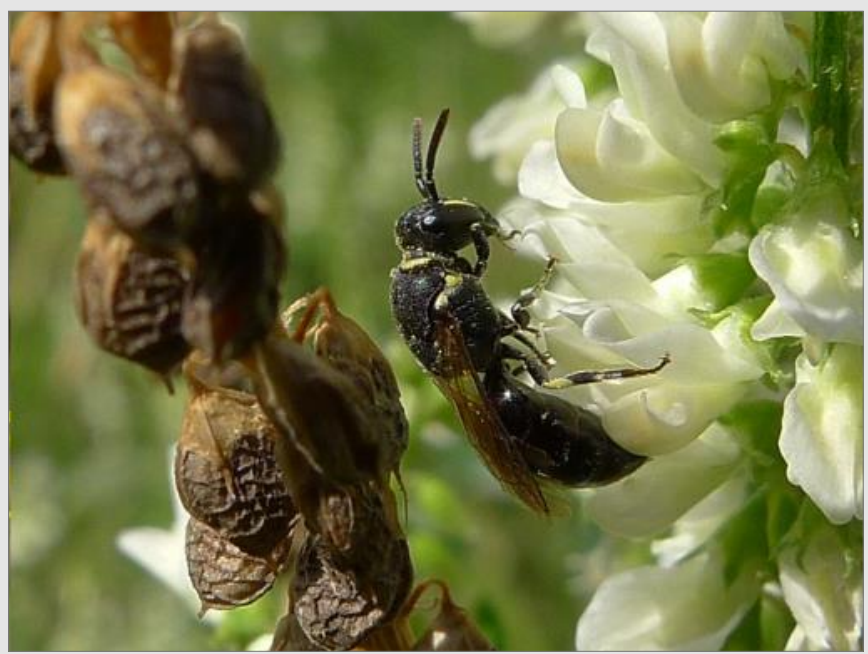

Hylaeus leptocephalus resembles a small wasp. It has no special pubescence. Thus Hylaeus collects pollen in its mouth. It builds nests in different hollows, including those found in dead wood.

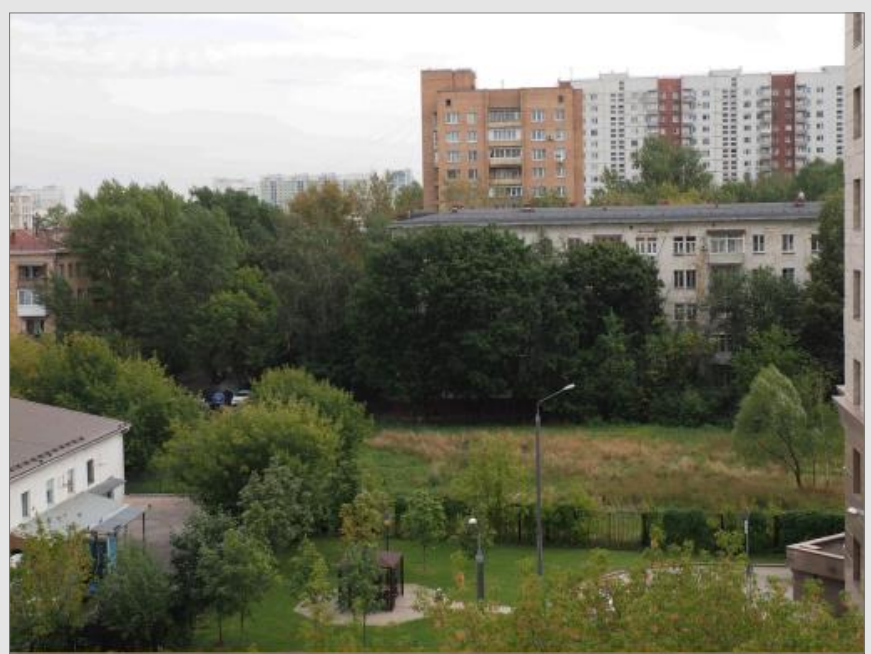

Part of the Cherished meadow seen from the roof of the State Darwin Museum. Dried grass stems (beyond the fence) are saved for bees and other overwintering insects.

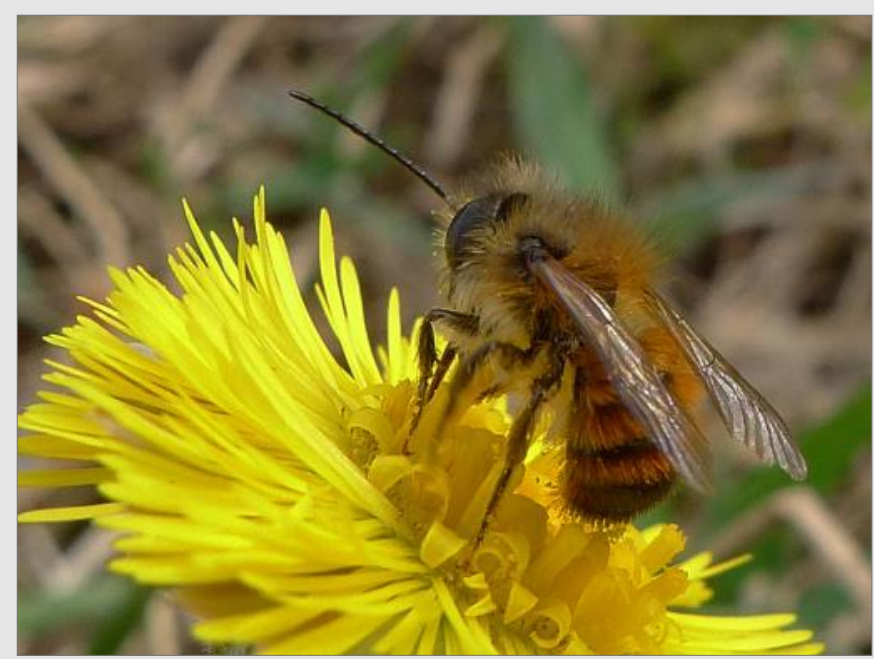

Osmia bicornis builds nests in the hollows found in trees, stones, and bricks. Consequently it is able to locate suitable nesting sites in the city. However, it also needs spring flowers to survive.

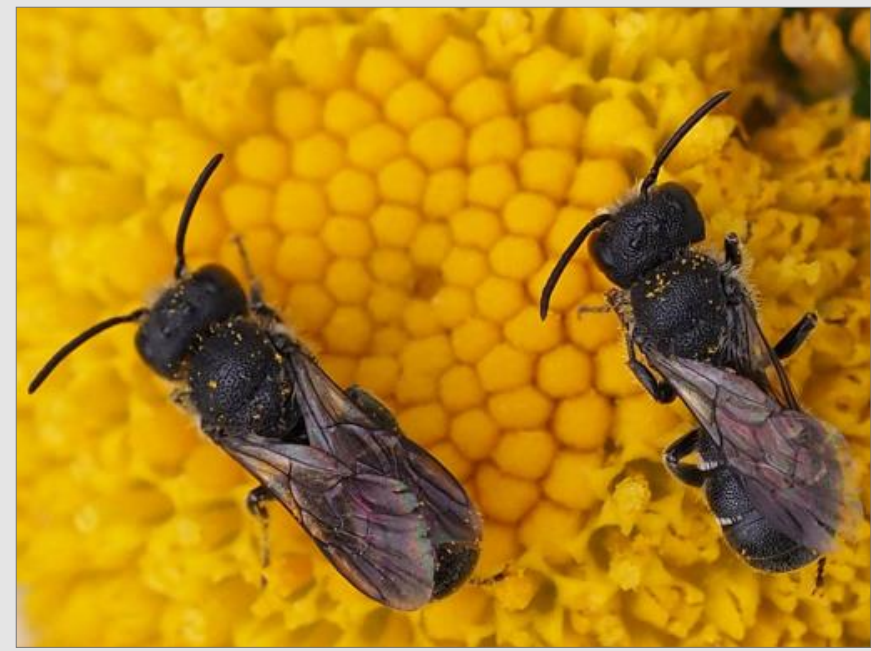

Heriades truncorum is a very common bee in the Meadow. It is known to be a tree hollow nester. However, in Moscow's streets, it seems to use other materials for nesting.

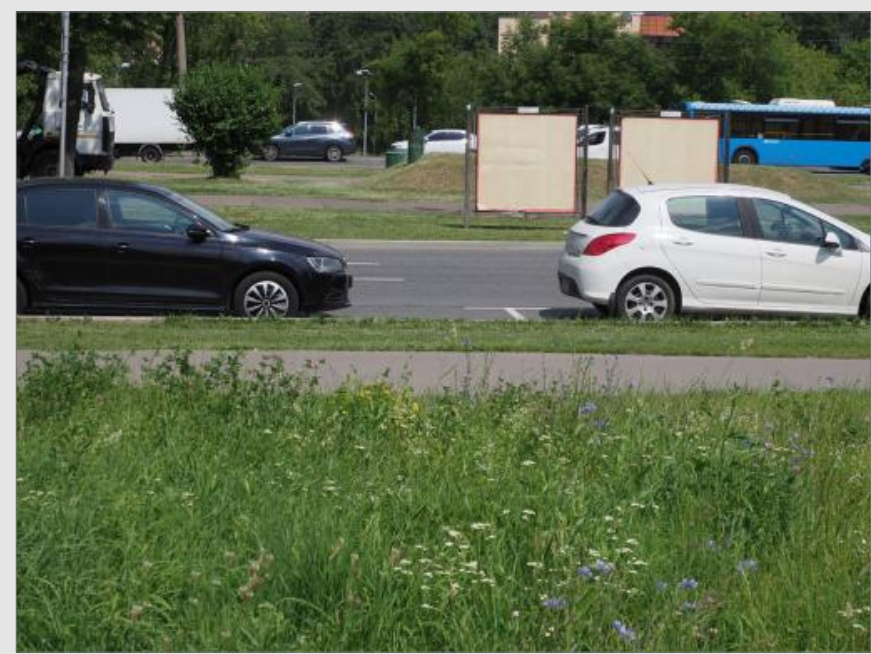

Contrast between the flowering wild grassland of the Meadow and the mown lawn on D. Ulyanova ul. Bees could use the sparse herbage for ground nesting. However, the lawn does not provide food for bees to survive. 


\section{Glimpses of a Grassland}

This new section titled as "Glimpse of a Grassland" is intended to present short stories and nice photos of grasslands. In this current issue, the section includes 2 grasslands across the Palaearctic (see the Map below). We hope you will enjoy reading it. If you'd like to share your stories, please send them to anyameadow.ak@gmail.com following a few rules:

- 1-2 authors; please provide also your current city, country and e-mail;

- Appealing title followed after an en-dash by a subtitle that indicates the locality and country;

- Each "glimpse" should deal with one grassland site, but can do this with very different focus: landscape, animals, vegetation types, management.

- You should pick a grassland site that is dear to you, for example, because it is extraordinary or beautiful, you worked there a lot or you would normally be there in this season (if there would not be the Corona restrictions)

- Please provide the coordinates of your grassland site (lat/lon in decimal degrees, elevation in $\mathrm{m}$ a.s.l.)

- Please provide 3-8 photos with captions (including the scientific names of illustrated species and the name of the photographer). One photo should be an overview photo of your grassland site in landscape format, suitable for printing the title across it. Instead of photos also scans of drawings and paintings are possible.

- We expect a personal text written in the first person and in a less "dry" style than usual scientific articles. Also a poem would be a possibility. Maximum length is 600 words.

- Please do not cite references in your text, but you can give up to three references (in normal PG style) at the end under the heading "Further reading"

Didem Ambarlı \& Chief Editor Team

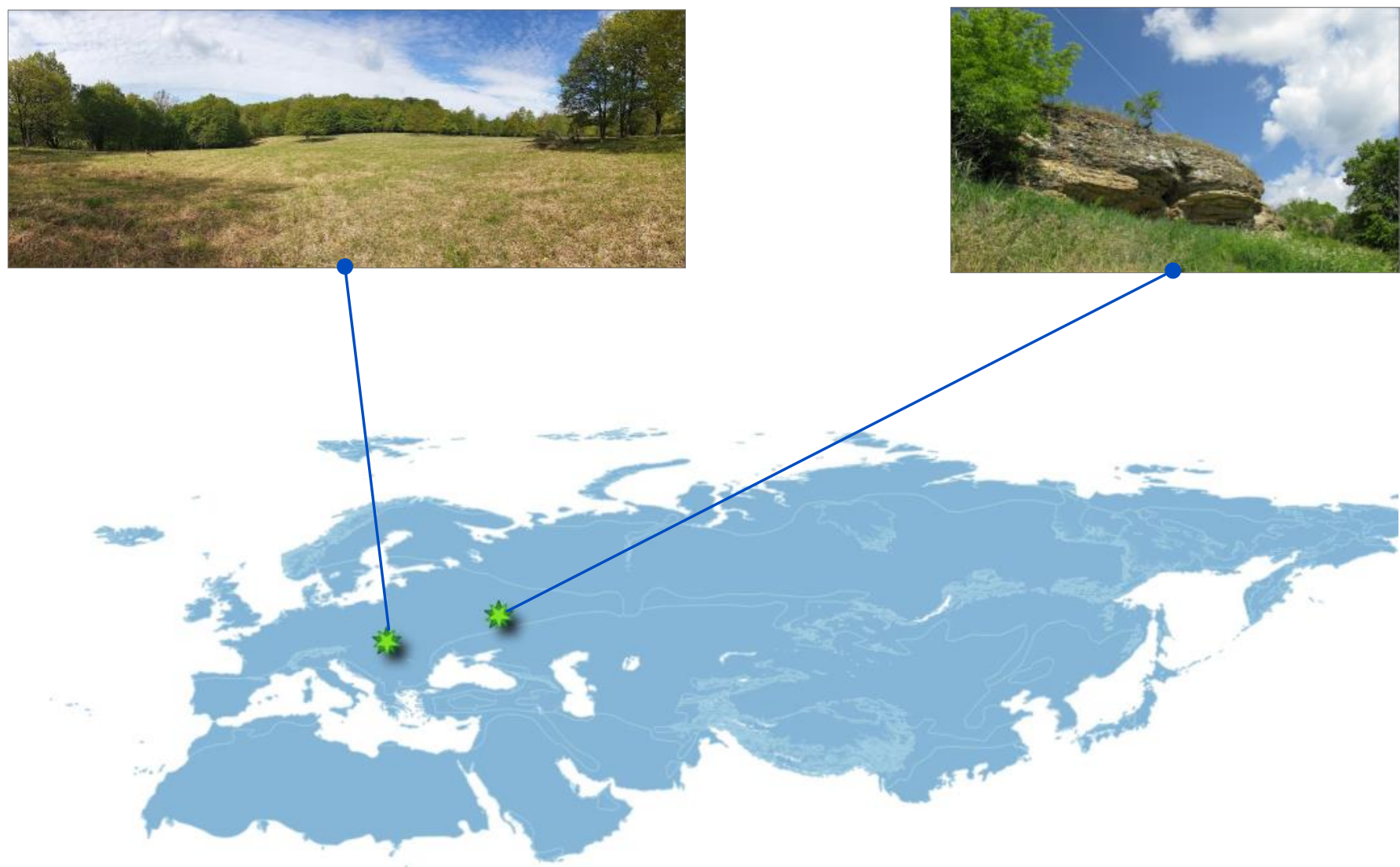




\section{Glimpses of a Grassland}

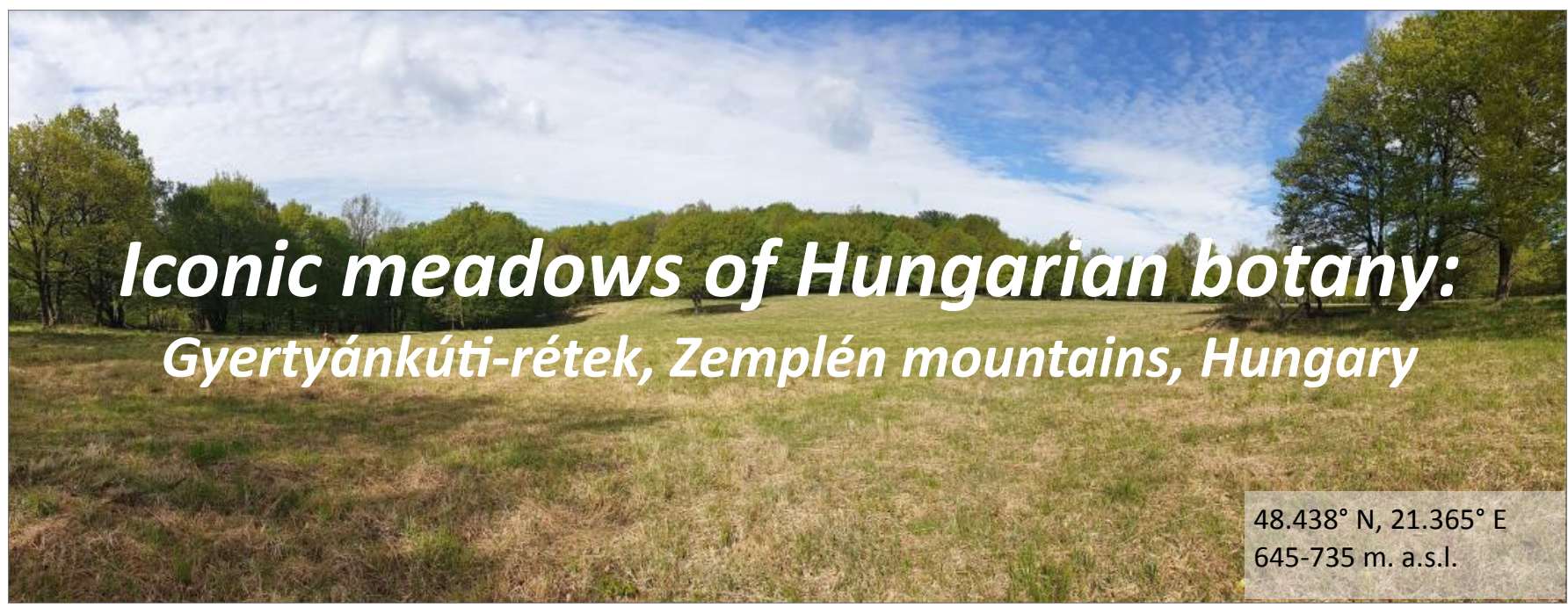

The center part of the meadow in the Spring. Photo: M. Prommer.

Situated deep in Zemplén Mountains (NE Hungary) - the remotest and mightiest mountains of Hungary - Gyertyánkúti-rétek (Gyertyánkút meadows) is a famous and iconic site of Hungarian botany. The meadows which are surrounded by forests, have evolved on acidic-bedrock-formed compact forest soils with moderately rich humus content.

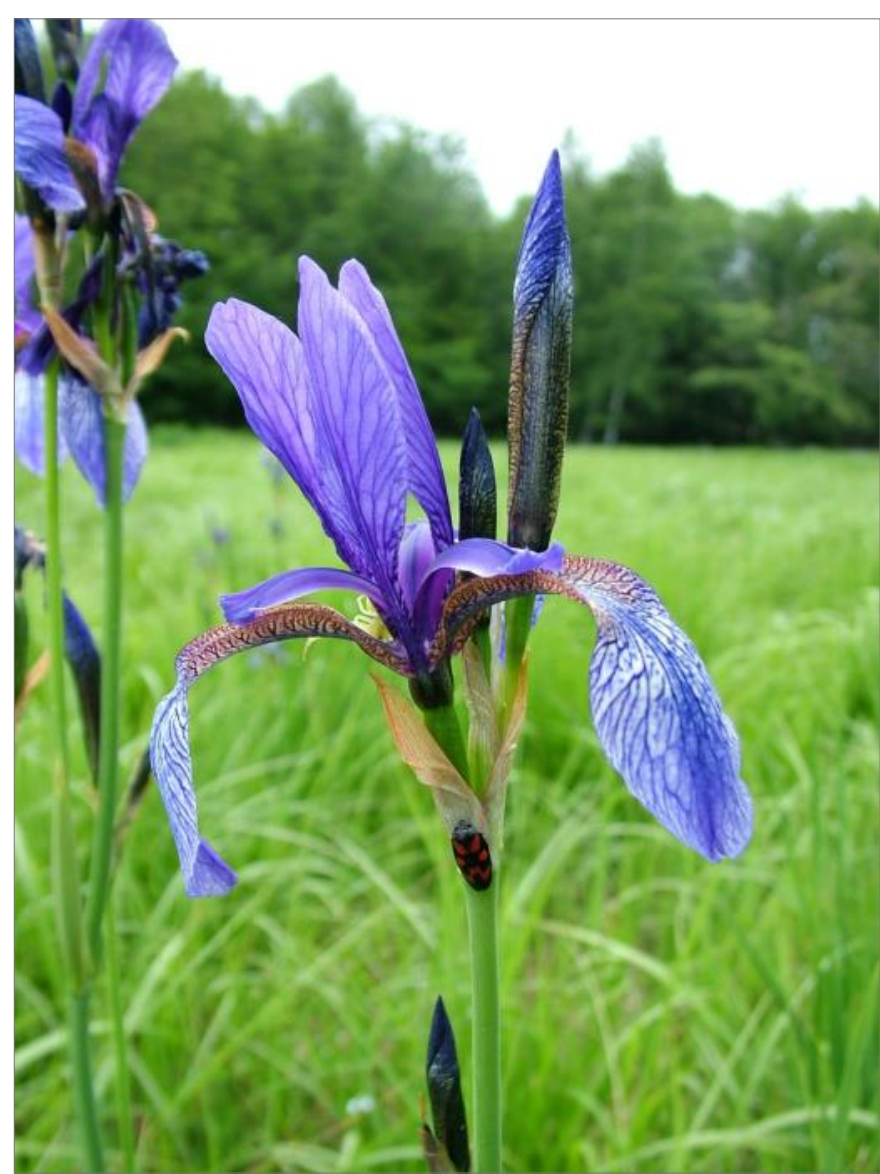

Iris sibirica. Photo: P. Török.
The Molinion meadows have high cover of Molinia arundinacea and the adjacent dry-mesophilous meadows are characterised by Brachypodium pinnatum, Calamagrostis arundinacea and Carex montana. The strictly protected meadows provide home for a diverse flora and fauna. They are inhabited by 350 vascular plant species ( 41 protected by the law) including 18 orchids and threatened species such as the protected Gladioulus imbricatus, Adenophora liliifolia, Achillea ptarmica, Gentiana pneumonanthe, Dactylorchiza fuchsii, Gentianella livonica, or Traunsteineria globosa. The fauna has a Carpathian subendemic Orthoptera species: the flightless Pholidoptera transsylvanica, and hosts other rarities including Brenthis ino, various Maculinea species and Vipera berus.

Most mountain hay meadows in the region were created by cuts of oak, oak-hornbeam, and beech forests, thus creating a diverse quasi-subalpine grassland habitat within the forest zone, considerably lower than the subalpine zone can be found. The creation of the hay meadows in the Zemplén Mountains dates back to the $17-18^{\text {th }}$ centuries, when settlers from the Carpathians moved in the uninhabited region abandoned by previous inhabitants as a result of wars. Until the $20^{\text {th }}$ century, the meadows were maintained by hand-mowing once a year, typically in July or early August. In the 1960's, socio-economic changes in the communist era lead to the gradual abandonment of the meadows and forest started to reclaim this realm immediately. Birch and hornbeam occupied most meadows, and some parts were even afforested by spruce. Thus, the once 100 ha meadows shrank to about 12 ha by the early 1980's. In order to preserve the grassland habitat and its species, students and professors of Kossuth Lajos University (now University of Debrecen) started restoration works unofficially, in the late 1980's, and in 1993 a formal restoration plan was developed in cooperation with conservation authorities. 
The meadows "served" also as education sites for three generations of Hungarian botanists and conservation biologists. Authors of this paper started to work as students on the restoration of Gyertyánkút meadows. We hand-mowed and raked, which were more difficult tasks than we expected in the beginning. We were monitoring vegetation changes in permanent plots established at the very beginning of restoration works in three habitat types: Molinion meadows, drymesophilous meadows and former birch forest stands. We learnt much about species, especially grasses and sedges and their identification in various life-stages (especially in vegetative forms without flowers). For us, the evenings far from settlements, making suppers often of mushroom collected nearby, sitting around the campfire consuming local vines or/and beers and exchanging stories with and about our supervisors, not even mentioning the unpredictable and often pouring rains, hordes of mosquitos, painful bites from various insects and injuries from hooky plants, became unforgettable memories. Nowadays, the meadows are mowed by Aggtelek National Park Directorate. We hope that the meadows will fascinate further generations of botanists and ecologists in the forthcoming centuries.

\section{Further reading}

Török, P., Arany, I., Prommer, M., Valkó, O., Balogh, A., Vida, E., Tóthmérész, B. \& Matus, G. 2009. Vegetation, phytomass and seed bank of strictly protected hay-making Molinion meadows in Zemplén Mountains (Hungary) after restored management. Thaiszia - Journal of Botany (Kosice) 19: 67-77.

Valkó, O., Török, P., Matus, G. \& Tóthmérész, B. 2012. Is regular mowing the most appropriate and cost-effective management maintaining diversity and biomass of target forbs in mountain hay meadows? Flora 207: 303-309.

Valkó, O., Török, P., Tóthmérész, B. \& Matus, G. 2011. Restoration potential in seed banks of acidic fen and drymesophilous meadows: Can restoration be based on local seed banks? Restoration Ecology 19: 9-15.

Péter Török, Debrecen, Hungary molinia@gmail.com

Mátyás Prommer, Debrecen, Hungary mprommer@yahoo.com

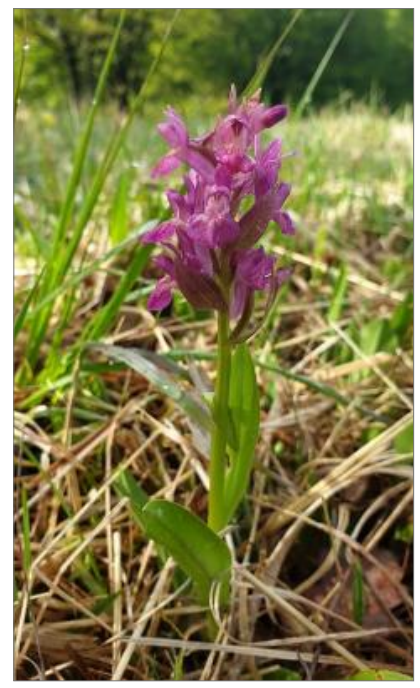

Dactylorhiza incarnata. Photo: M. Prommer.

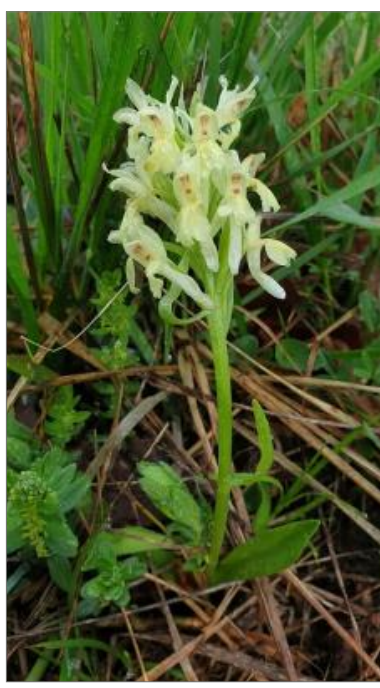

Dactylorhiza sambucina. Photo: M. Prommer.

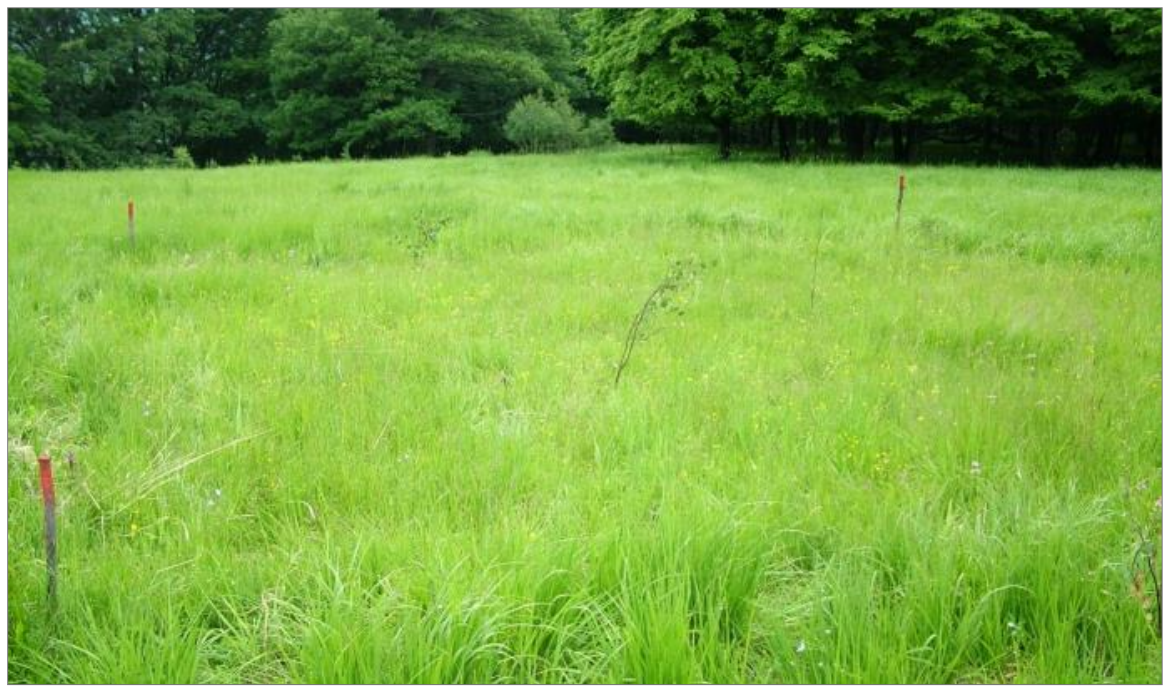

Mown experimental Molinion meadow plot in 2006. Photo: P. Török.

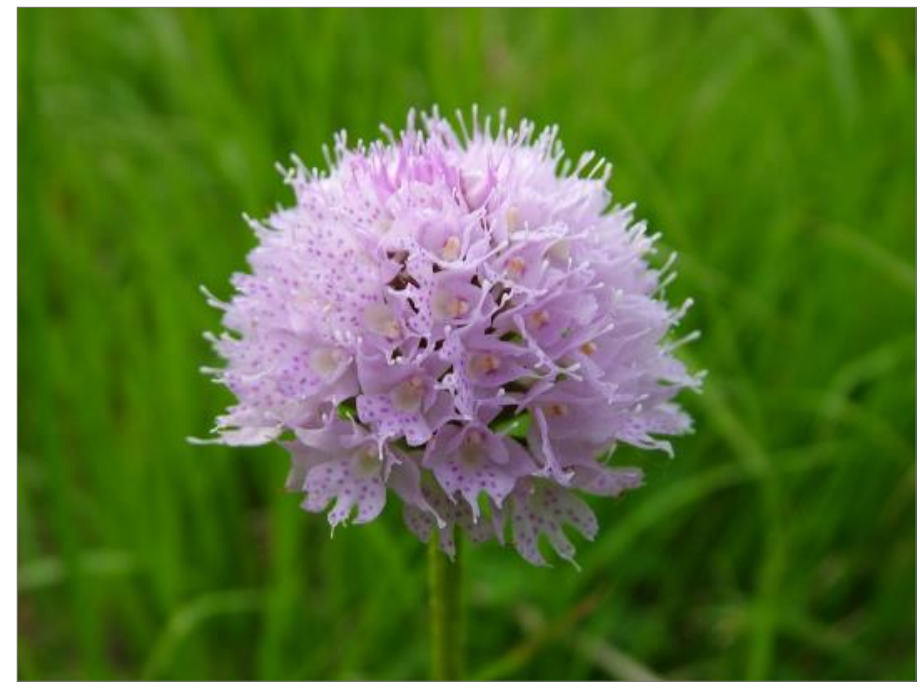

Traunsteineria globosa. Photo: P. Török.

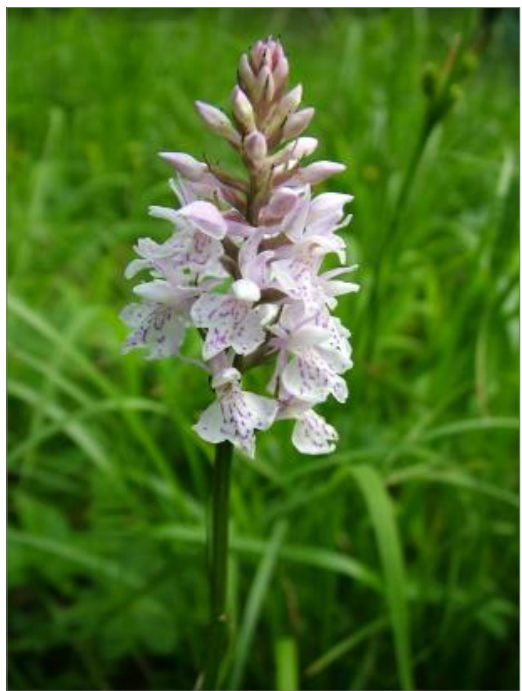

Dactylorhiza fuchsii. Photo: P. Török. 


\section{Glimpses of a Grassland}

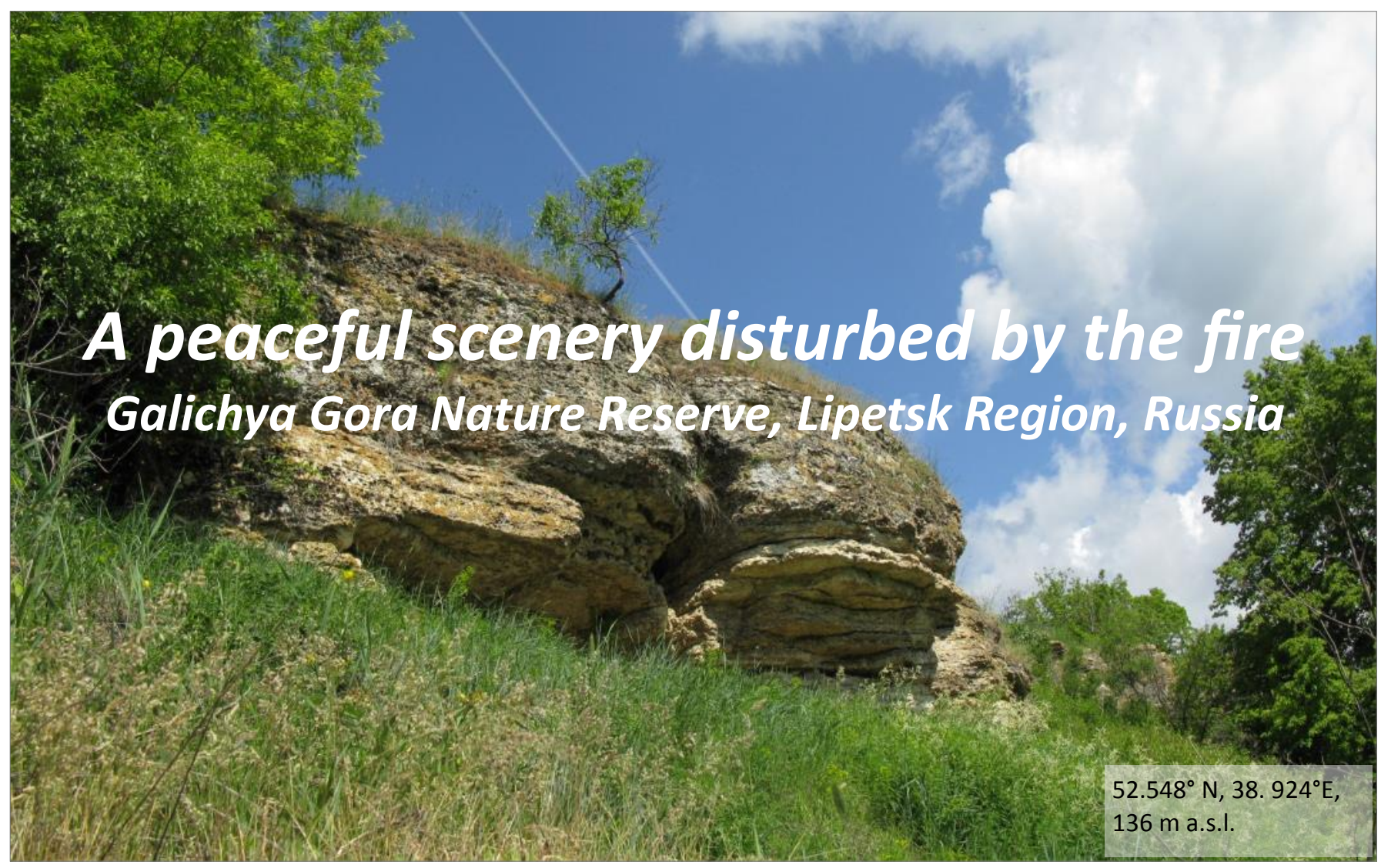

Galichya Gora Nature Reserve is located in the forest-steppe part of the Central Russian Uplands. Six reserve segments with a total area of 234 ha present the typical natural habitats of the Upper Don region - oak and birch forests, steppes and meadows. The gem of the region is rocks of Devon limestone with karst sinkholes. The most famous is the Galichya Gora segment discovered in 1880s, which surprised Russian botanists with rare species originating from the Alps, Caucasus and Mountain Altai. At that time, it was a sensation. Later on, the area was described as a Northern Don Relic Botanical Region, which hosts a number of plants, which exist far away from their main areas (Potentilla pimpinelloides L., Campanula rotundifolia L., Draba sibirica (Pall.) Thell, Schivereckia podolica (Besser) Andr. ex DC, Alyssum gmelinii Joed., etc). Despite the small size, the reserve is a biodiversity hotspot. There are over 1000 species of vascular plants, over 5700 invertebrate species, and 1600 species of mycobiota recorded from its territory.

I arrived at the reserve in July 2010 with the purpose of organizing arachnological research. Together with the reserve staff, we investigated three sites and planned the future study. The day was extremely hot and windy. Morozova Gora and Glichya Gora faced each other on opposite sides of the riverbank admiring their reflections in the calm Don flow. Suddenly, we smelled burning and in half an hour, the fire burst into our life. In a moment, it engulfed the steppe plot, leaving bare soil with the bumps of anthills and started devouring the forest. Then it slowed down in the floodplain meadow and finally died away near the river. It was all over in a few hours. Luckily, people and households were not affected, but nearly the whole Morozova Gora segment was burnt.

The next day we observed the territory to assess the consequences. The trees in the forest were still smoldering, but we met butterflies and grasshoppers on the charred steppe shrubs, and I counted from three to seven spiders on each inflorescences of surviving umbellifers in the meadow. Life was getting back on track!

I already had experience in investigating an extended fire in the Ukrainian steppes, but that day I understood that fire ecology is my destiny. Since then, I have been studying arthropod responses to grassland fires, revealing new details with every fire event. Fruitful fieldwork conducted with Mikhail Tsurikov, a scientific researcher of the Galichya Gora Reserve, resulted in a compilation of annotated spider lists of the reserve segments, identification of rare species in need of protection, and an analysis of the fire impact on the reserve's fauna. The devastating fire did not profoundly change the communities of steppe arthropods. In the first post-fire year, spider and beetle assemblages manifested 
small differences in the assemblage structure, but the twoyear studies revealed that the annual fluctuations in arthropod diversity in the same habitat were higher than their differences at the burnt and unburnt plots. The forest arthropods were slower in their recovery. This requires further research.

This essay is dedicated to the memory of Mikhail Tsurikov, a keen entomologist and my fellow worker in the arthropod study in 2010-2012.

\section{Further reading}

Polchaninova, N., Tsurikov, M. \& Atemasov, A. 2016. Effect of summer fire on cursorial spider (Aranei) and beetle (Coleoptera) assemblages in meadow steppes of Central European Russia. Hacquetia 15: 113-132.

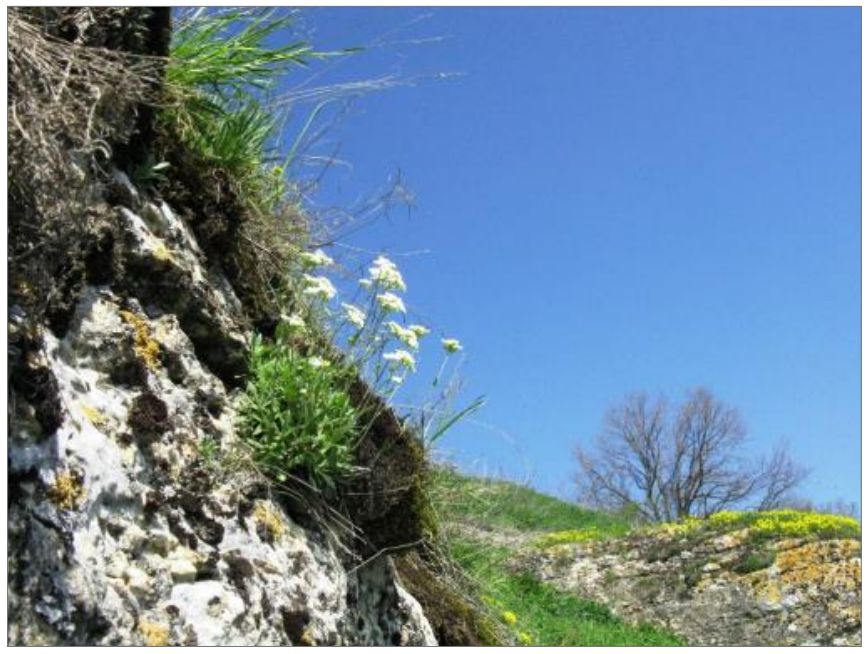

Schivereckia podolica and Alyssum gmelinii (background).

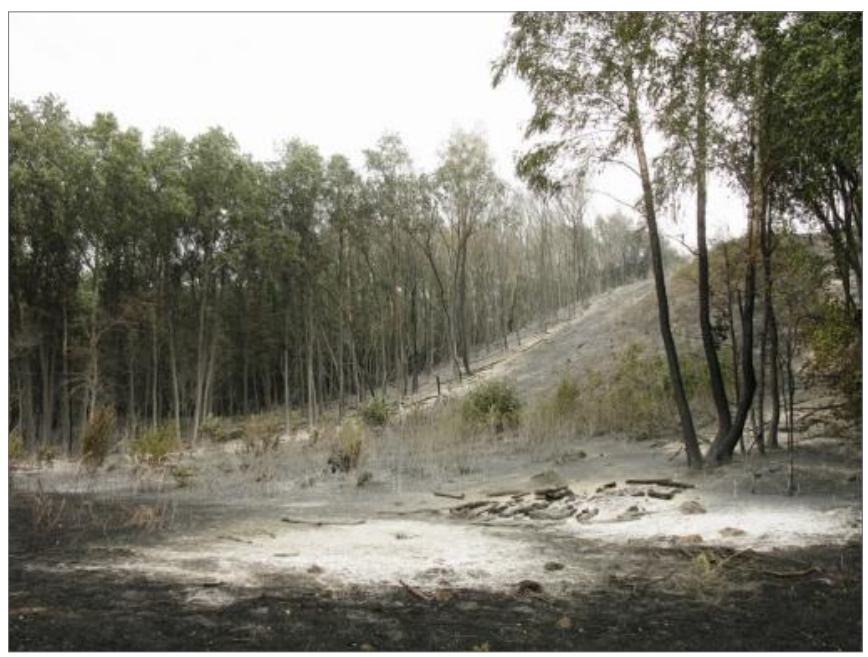

First post-fire morning.
Tsurikov, M.N. 2016. Invertebrates of the Nature Reserve 'Galichya Gora'. Isdatelskij Dom VGU, Voronezh. [in Russian]

Tsurikov, N.M. \& Polchaninova, N.Y. 2015. Post-fire recovery of the ground dwelling beetles (Coleoptera) and spiders (Araneae) in a steppe gully 'Bykova Sheya' (Lipetsk Region, Russia). In: Chibilev A.A. (ed.) Steppes of Northern Eurasia: Materials of VII International Congress, pp. 899903. IS UrD RAS, "Dimur", Orenburg: [in Russian with English summary]

Nina Polchaninova, Kharkiv, Ukraine polchaninova n@ukr.net

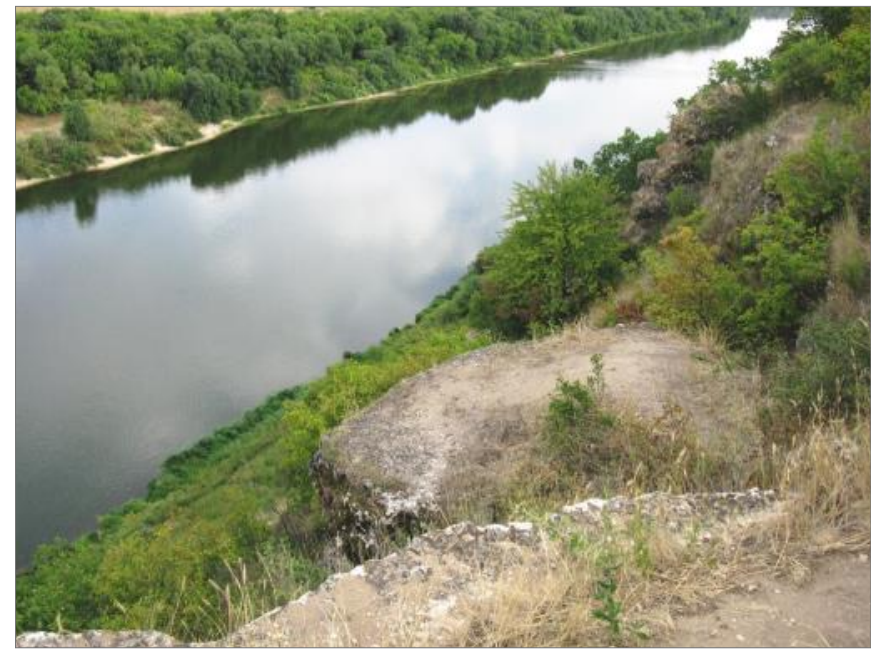

River Don.

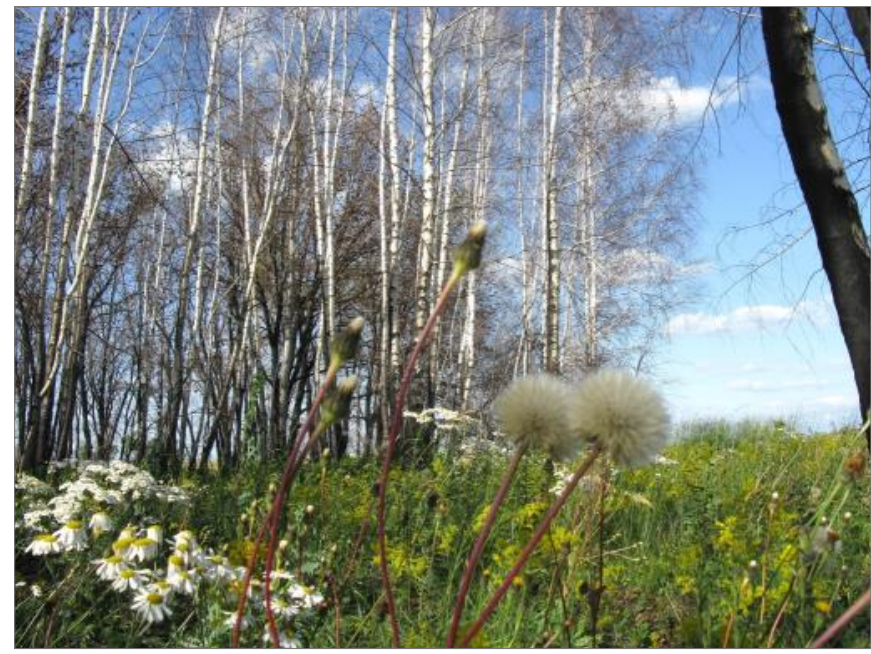

July 2011, a year after the fire. 


\section{Photo Competition}

\section{Home grasslands}

We wish to thank all authors of photographic contributions received for the current issue!

As submissions of Photo Competition were considered too few by the jury, we apologize that we could not select winners for this edition. We look forward for a greater participation for the next issue of Palaearctic Grasslands!

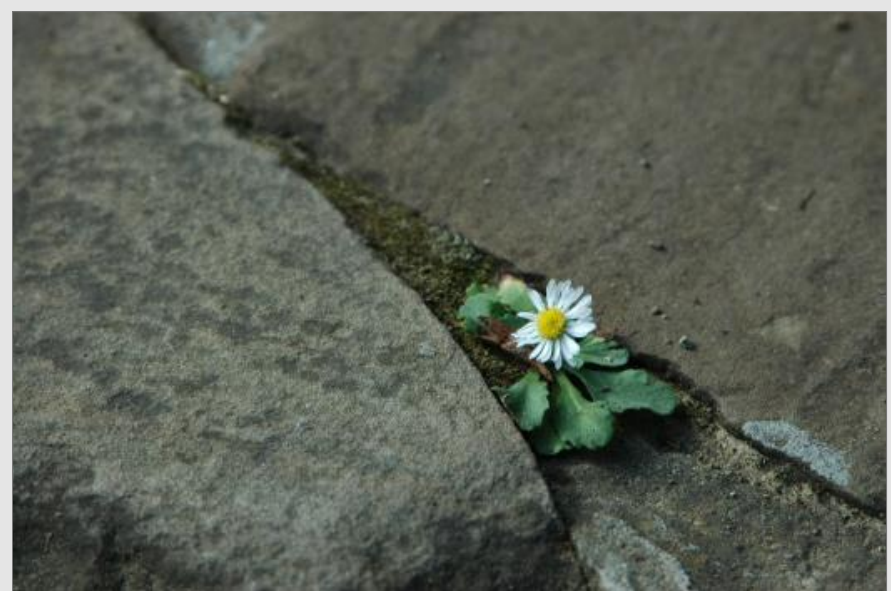

Bellis sp. grows on the street in the old part of Veliko Tarnovo, Bulgaria. Photo: I. Sirenko.

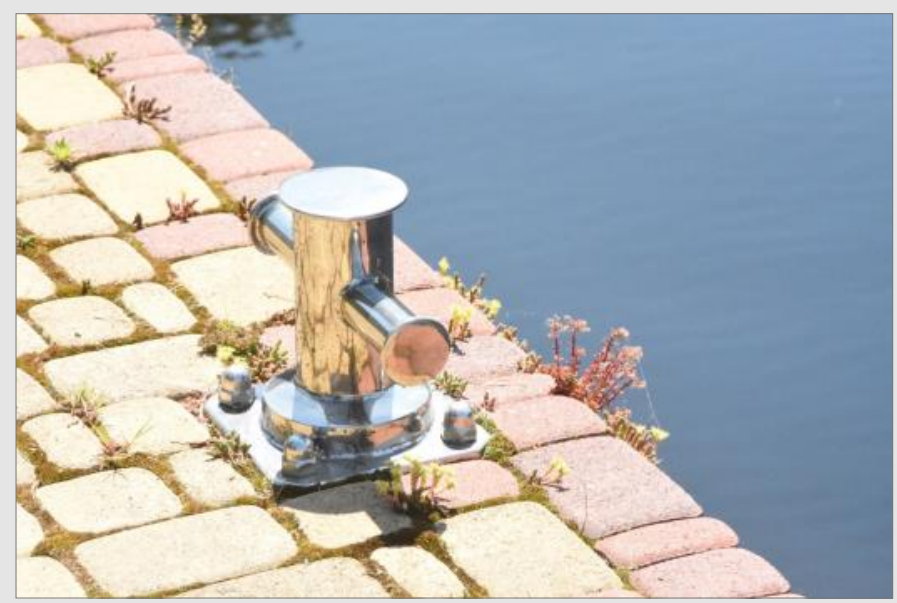

Sedum spp. growing on the berth of the yacht harbor in the Kyiv reservoir, Ukraine. Photo: I. Sirenko.

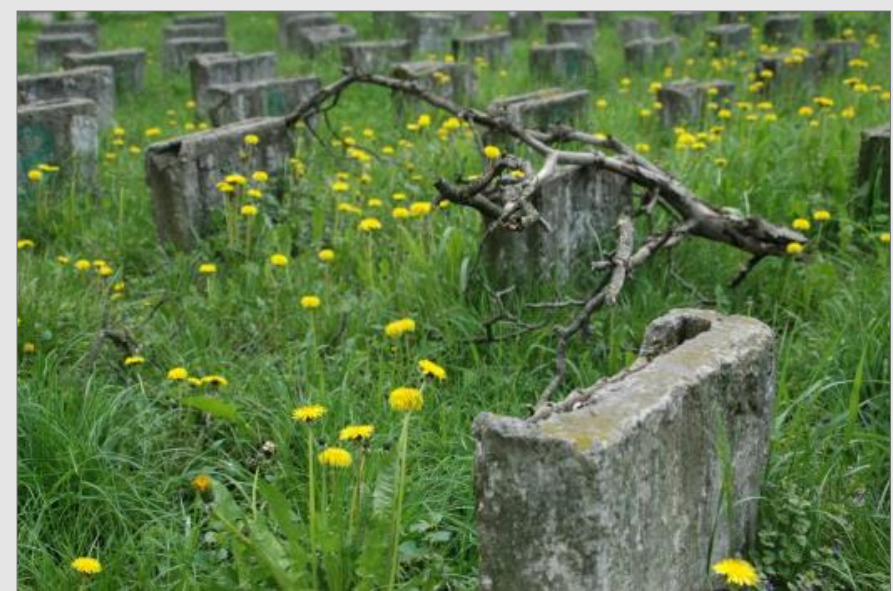

Wild lawn replaced the benches in a depressed residential district of Kyiv, Ukraine. Photo: I. Sirenko.

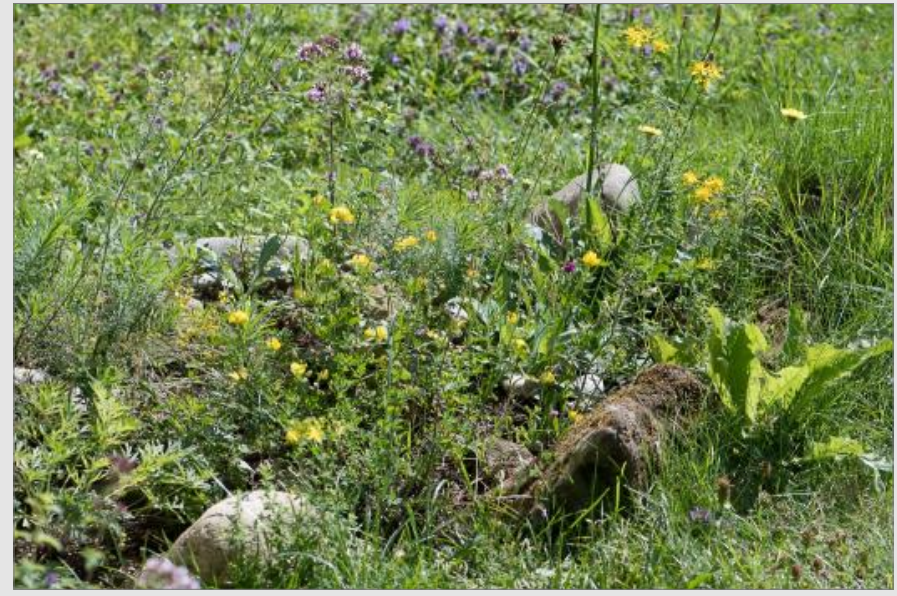

A $2 \mathrm{~m}^{2}$ dry grassland created during the lockdown to replace a formerly species-poor lawn. Photo: J. Dengler. 


\section{Short Contributions}

\section{Photos of the Ukrainian steppes in protected areas}

The international Wiki Loves Earth competition was launched in Ukraine in 2013. The photography competition is in its eighth year and in 202034 countries took part. The purpose of the competition is to collect photographs of natural heritage and draw attention to the wildlife within the protected areas of the participating countries. In previous years contestants have uploaded more than 80,000 images of national parks, nature reserves, and botanical gardens to Wikimedia Commons. Over the eight years of the competition Ukrainian participants have taken more than 110,000 photographs of the country's wildlife and it is the largest repository of such images in Ukraine.

This year, at the suggestion of the Ukrainian Nature Conservation Group and the charitable fund Biodiversity Conservation Fund of Ukraine the special category of 'Wildlife photographs of the Ukrainian steppes' was announced as part of the competition. It is hoped that this special category will help draw attention to the large-scale problem of plowing within the last remnants of the steppes.

The jury evaluated all the photographs within this new category, which included images which either fully or partially depicted steppe landscapes, plants, or animals. The jury were stunned by the number of images that were sent in, especially considering that steppe landscapes are only present in a few regions of Ukraine and are mostly located outside protected areas. In total, the participants uploaded 3,431 steppe photos, which was more than $15 \%$ of all competition entries!

The jury for this special category were:

- Anna Kuzemko, Dr. habil. of Biological Sciences, Institute of Botany of the National Academy of Sciences of Ukraine

- Ivan Moysiyenko, Dr. habil. of Biological Sciences, Head of the Botany Department of Kherson State University

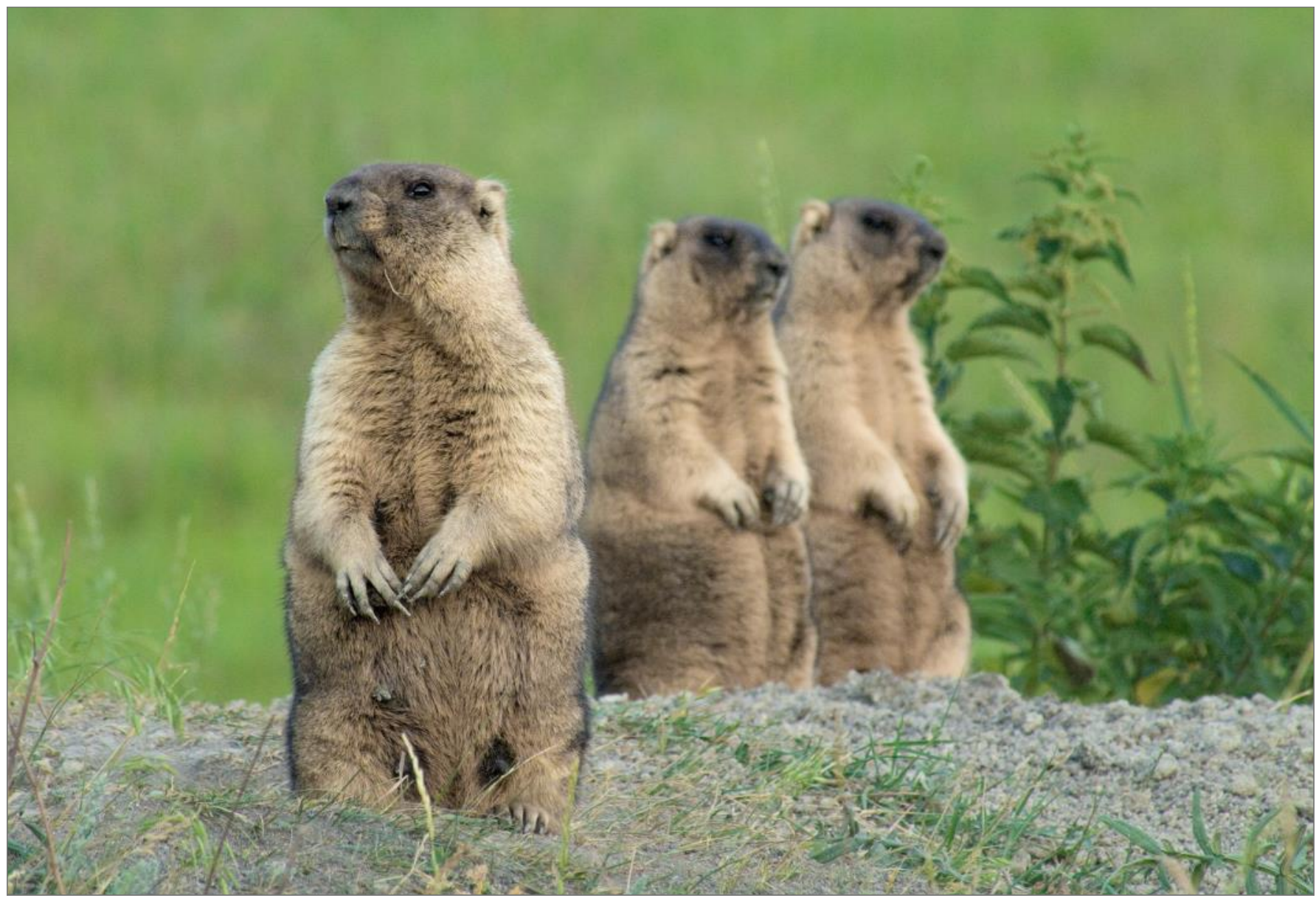


- Kateryna Strypko, Director of the charity fund Biodiversity Conservation Fund of Ukraine, Competition Partner

- Olga Chusova, Ph.D. of Biological Sciences, Junior Researcher at the Institute of Botany of the National Academy of Sciences of Ukraine

- Olena Bronskova, a researcher at Meotida National Nature Park

From the photos entered into this special category the competition jury plan to create a photo album that will raise awareness of the importance of protecting the Ukrainian steppes. The accompanying text for the photos has already been prepared by a well-known defender of the steppes, eco-blogger Oleksiy Burkovsky.

There were hour winners of this special category, who each scored the same number of points.

1. Reserve "Cretaceous Flora," Donetsk region, author Oleksiy Solovkin

https://w.wiki/d28

https://w.wiki/d2A
2. National Natural Park "Dvorichansky," Kharkiv region, author Alsamua

https://w.wiki/d29

https://w.wiki/d2D

3. Reserve "Dnieper Thresholds," Zaporizhzhia, author Yana Moseiko

https://w.wiki/d2B

4. Tiligul Regional Landscape Park, Odessa region, author Victor Krasyuk

https://w.wiki/d2C

We are extremely grateful to all participants for submitting their photos and we look forward to the 2021 competition.

Tetiana Shamina, Kyiv, Ukraine tatanavrotskaya@gmail.com

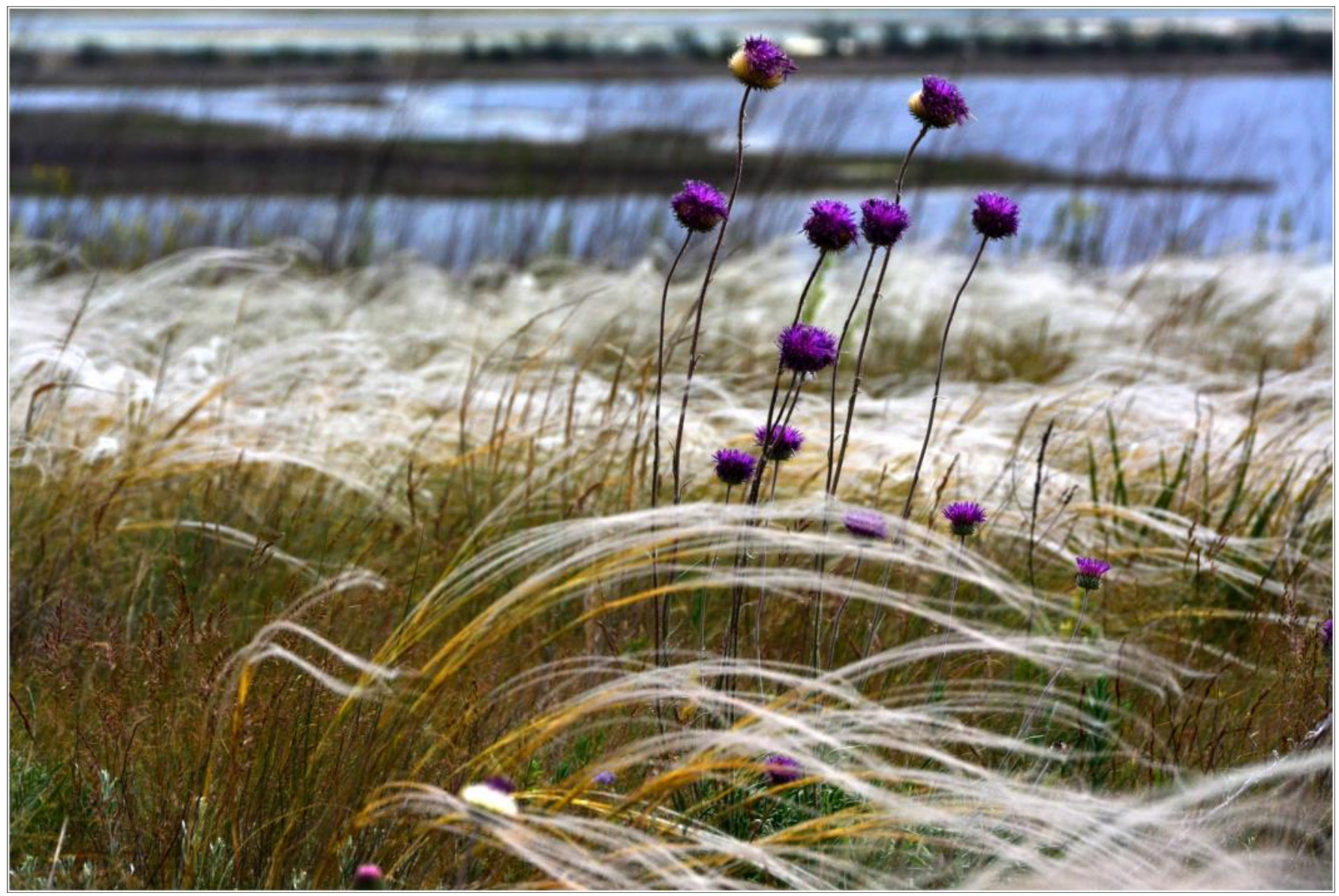

Feather grass (Stipa sp.) and Jurinea sp. near Tiligulskaya embankment. Photo: V. Krasyuk. 


\section{6 hectares of Emerald steppe saved from destruction}

The Ukrainian Nature Conservation Group, along with the Ministry of Environmental Protection and Natural Resources of Ukraine, have managed to prevent the destruction of 166 hectares of steppe forming part of the Emerald Network of Ukraine.

This autumn, as a part of the "Million Trees" action at state level, it was planned to create forest plantations within the territory of existing forestries. The Ukrainian Nature Conservation Group agrees with this approach, since creating integral forest plantations and their further inspection by foresters is more effective than spontaneous planting of individual trees. Without specialist knowledge, planting may take place in locations where trees cannot survive or thrive, may cause the spread of invasive species, or may destroy unique steppe habitats and important populations of steppe or meadow plants.

Today we know that all areas of steppe are protected by law, most of them contain rare Red List species, and many are included in reserves or form part of the Emerald Network of Europe.

Since 2019, the problem of steppe afforestation has been recognized at state level. Moreover, the law "On the Basic Principles of the State Environmental Policy of Ukraine until 2030 " states that the creation of new forests should not be carried out on unique steppe areas. After all, afforestation of steppe habitats leads to the loss of most steppe species, not least because planting is preceded by soil preparation such as plowing. In addition, due to the changing climate, it is inappropriate to create new forests in open areas of the steppe climate zone as they are likely to die within a few years of planting. As a result, such planting leads to the destruction of the steppe, does not lead to forest creation and ultimately provokes soil erosion.

To create forests as a part of the "Million Trees" action, some forestries offered the following areas: unique steppes included to the Emerald Network.

In order to prevent their destruction, experts of the Ukrainian Nature Conservation Group, together with the Ministry of Environmental Protection and Natural Resources of Ukraine, analyzed all of the sites proposed by forestries for tree planting. In 12 cases, they were revealed to be steppes included in the Emerald Network in Mykolayiv, Luhansk, Kirovohrad, Odesa, Kherson and Zaporizhia regions. Thanks to the work of environmentalists, these areas were all excluded from afforestation plans.

During the next year, the Ukrainian Nature Conservation Group plans to survey most of the steppe areas which have been afforested in the past, document Red List species and seek to justify the creation of reserves in all these areas. Environmentalists have a chance to save at least 50,000 hectares of steppe in various regions of Ukraine.

Olexiy Vasyliuk, Vasylkiv, Ukraine vasyliuk@gmail.com

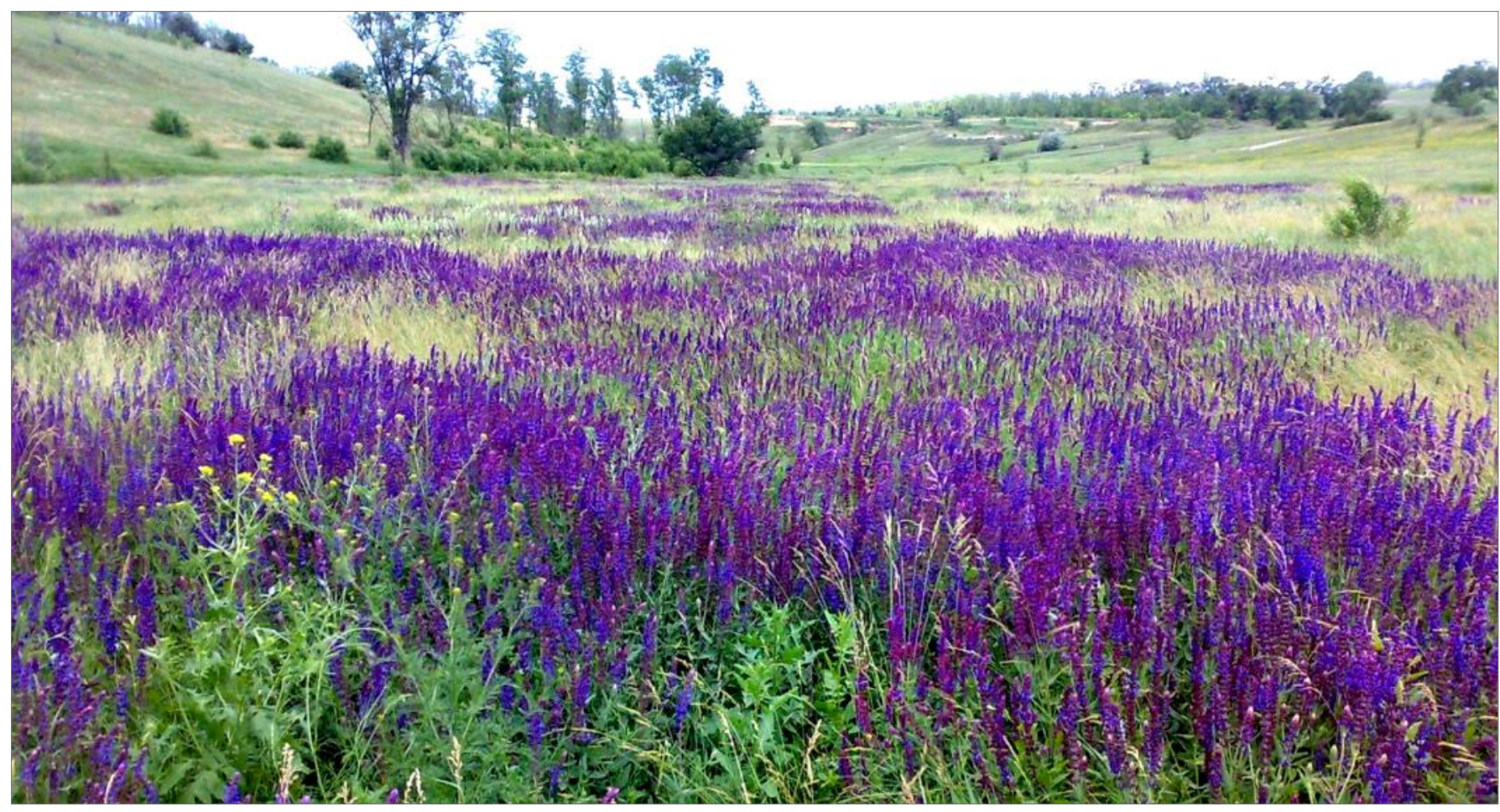

Gully on the right bank of the Dnieper River in the north of Kherson oblast, Ukraine. Photo: O. Dnipro. 


\section{Stroh, P., Walker, K., Smith, S., Jefferson, R., Pinches, C. \& Blackstock, T. 2019. Grassland plants of the British and Irish lowlands - ecology, threats and management. Botanical Society of Britain \& Ireland, ISBN: 9780901158611 Hard- back}

Species-rich grasslands are among the most threatened habitats types worldwide and have suffered dramatic magnitude of the decline in area (some grassland types extents decreased more than $90 \%$ in the last century - Dengler et al. 2014 and citations therein; Habel et al. 2013). In the Palaearctic, the most crucial driver of grassland biodiversity is the change of management intensity (Dengler et al. 2020).

Decline of grassland biodiversity by management change is caused either by the decrease in management intensity cessation of former extensive management and abandonment, or by the increased use - intensive management and overuse (increased rate of fertilisation, seeding by cultivars, increased frequency of cut or overgrazing, Dengler et al. 2014).

Stroh et al. (2019) book focuses on threatened grassland plants (categorised from critically endangered to near threatened based on IUCN criteria) of British and Irish lowlands (grasslands situated at an elevation below $300 \mathrm{~m}$ a.s.l.). The backbone and most voluminous part of the book introduces all 109 threatened plant species by focusing on their identification, habitat requirements, biogeography and ecological characteristics. It is very important that the authors tried to collect - based on published evidences - the management and conservation requirements of each species. Following a short intro, the authors introduce the most important grassland habitats in lowlands following the NVC classification. After the classification section, the authors introduce the most important drivers of lowland grassland biodiversity.

I found of great interest the section where the authors tried to compare the plant characteristics / trait spectra of threatened lowland grassland plants with that of other nonthreatened ones based on the expert list containing 458 lowland grassland species. With these analyses the authors have tried to answer why some lowland grassland plants are more threatened than others.

The book is well organised, nicely illustrated and is supplemented by several appendices listing for example to each of the 109 threatened species in which grassland habitat types they occur. It is of high-quality print with a nice, artistic de-

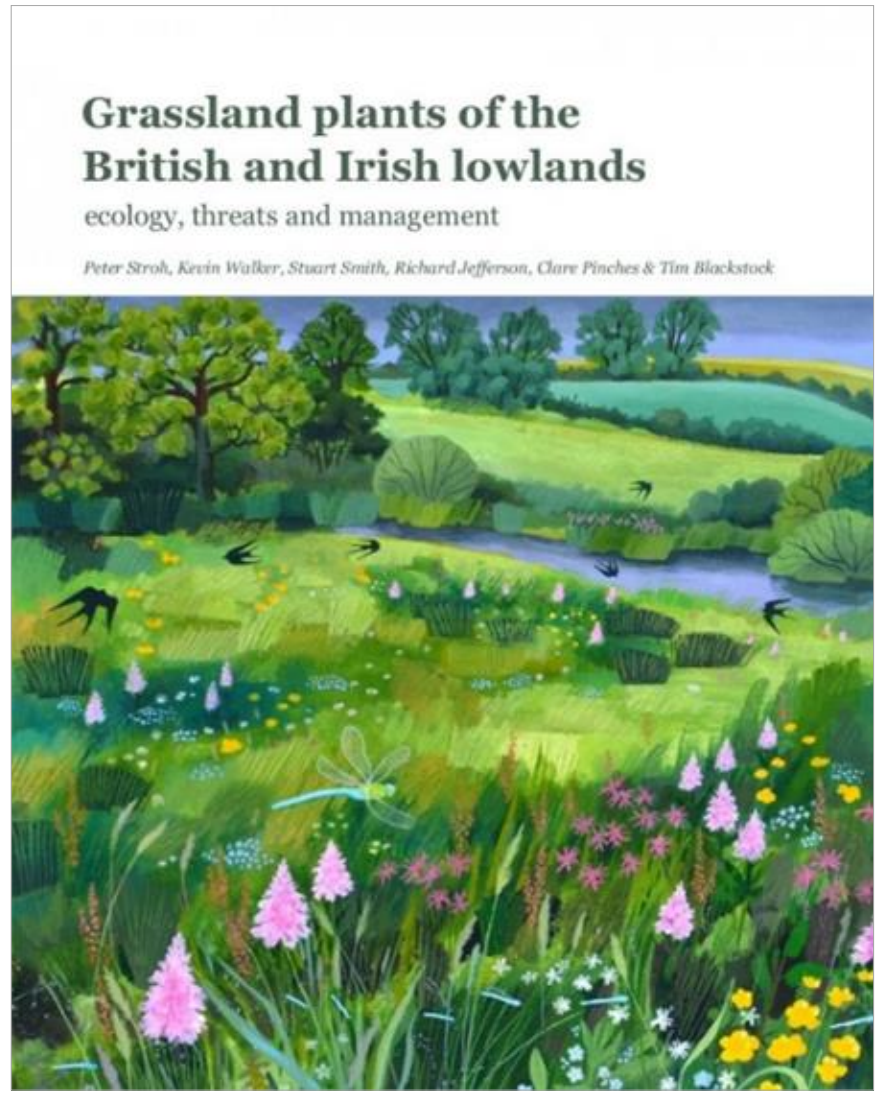

signed cover. To sum up, I think it is a useful guide of lowland grassland plants for all readers - including naturalists and researchers and site managers working in conservation and restoration.

\section{References}

Dengler, J., Janišová, M., Török, P. \& Wellstein, C. 2014. Biodiversity of Palaearctic grasslands: a synthesis. Agriculture, Ecosystems \& Environment 182: 1-14.

Dengler, J., Biurrun, I., Boch, S., Dembicz, I. \& Török, P. 2020. Grasslands of the Palaearctic biogeographic realm: introduction and synthesis. In: Goldstein, M.I. \& DellaSala, D.A. (eds.) Encyclopedia of the world's biomes, pp. 617-637. Elsevier, Amsterdam, NL

Habel, J.C., Török, P., Dengler, J., Janišová, M., Wiezik ,M., Stork, N. \& Wellstein, C. 2013. European grasslands: A threatened ecosystem biodiversity hotspot. Biodiversity \& Conservation 22: 2131-2138.

Péter Török, Debrecen, Hungary molinia@gmail.com 


\section{Recent Publications of our Members}

In this section, the contents of which will also be made available via our homepage, we want to facilitate an overview of grassland-related publications throughout Eurasia and to improve their accessibility. You are invited to send lists of such papers from the last three years following the format below to Iwona Dembicz, i.dembicz@gmail.com. We will include your e-mail address so that readers can request a pdf. For authors who own full copyright, we can also post a pdf on the EDGG homepage.

\section{Methodology, classification, databases}

Chytrý, M., Tichý, L., Hennekens, S.M., Knollová, I., Janssen, J.A.M., Rodwell, J.S, Peterka, T., Marcenò, C. Landucci, F., Danihelka, J., Hájek, M., Dengler, J., (...) \& Schaminée, J.H.J. in press. EUNIS Habitat Classification: expert system, characteristic species combinations and distribution maps of European habitats. Applied Vegetation Science. DOI: 10.1111/avsc.12519.

\section{Biodiversity \& ecology}

Dembicz, I., Velev, N., Boch, S., Janišová, M., Palpurina, S., Pedashenko, H., Vassilev, K. \& Dengler, J. in press. Drivers of plant diversity in Bulgarian dry grasslands vary across spatial scales and functional-taxonomic groups. Journal of Vegetation Science. DOI: 10.1111/jvs.12935.

Dembicz, I., Moysiyenko, I.I., Kozub, Ł ., Dengler, J., Zakharova, M. \& Sudnik-Wójcikowska, B. in press. Steppe islands: where island biogeography meets the reality of a severely fragmented habitat. Journal of Vegetation Science. DOI: 10.1111/jvs.12930.

Koncz, P., Vadász-Besnyői, V., Csathó, A.I., Nagy, J., Szerdahelyi, T., Tóth, Z., Pintér, K., Fóti, S., Papp, M., (...) \& Bartha, S. 2020. Carbon uptake changed but vegetation composition remained stable during transition from grazing to mowing grassland management. Agriculture, Ecosystems \& Environment 304: 107161. DOI: 10.1016/i.agee.2020.107161.

Kouba, Y., Merdas, S., Mostephaoui, T, Saadali, B. \& Chenchouni, $\mathrm{H}$. in press. Plant community composition and structure under short-term grazing exclusion in steppic arid rangelands. Ecological Indicators 120. DOI: 10.1016/j.ecolind.2020.106910.

Sporbert, M., Keil, P., Seidler, G., Bruelheide, H., Jandt, U., Aćić, S., Biurrun, I., Campos, J.A., Čarni, A., Chytrý, M. Ćušterevska, R., Dengler, J., (...) \& Welk, E. in press. Testing macroecological abundance patterns: The relationship between local abundance and range size, range position and climatic suitability among European vascular plants. Journal of Biogeography. DOI: $10.1111 /$ jbi.13926.

Valencia, E., de Bello, F., (...), Dengler, J., (...) \& Götzenberger, L. in press. Directional trends in species composition over time can lead to a widespread overemphasis of year-to-year asynchrony. Journal of Vegetation Science. DOI: 10.1111/jvs.12916.

Valencia, E., de Bello, F., Galland, T., Lepš, J., Vojtkó, A., van Klink, R., Carmona, C.P., Adler, P.B., Danihelka, J., Dengler, J., (...) \& Götzenberger, L. in press. Global drivers of plant community stability in natural ecosystems: synchrony matters more than species richness. Proceedings of the National Academy of Sciences of the USA. DOI: 10.1073/pnas.1920405117.

Valkó, O., Lukács, K., Deák, B., Kiss, R., Miglécz, T., Tóth, K., Tóth, Á., Godó, L., Radócz, S., (...) \& Tóthmérész, B. 2020. Laundry washing increases dispersal efficiency of cloth-dispersed propagules. NeoBiota 60: 1-16. DOI: 10.3897/neobiota.61.53730.

Valkó, O., Tölgyesi, C., Kelemen, A., Bátori, Z., Gallé, R., Rádai, Z., Bragina, T.M., Bragin, Y.A. \& Deák, B. in press. Steppe Marmot (Marmota bobak) as ecosystem engineer in arid steppes. Journal of Arid Environments. DOI: 10.1016/j.jaridenv.2020.104244.

\section{Conservation and Restoration}

Deák, B., Valkó, O., Tóth, C.A., Botos, Á. \& Novák, T. 2020. Legacies of past land use challenge grassland recovery - An example from dry grasslands on ancient burial mounds. Nature Conservation 39: 113-132. DOI: $\underline{10.3897 /}$ natureconservation.39.52798.

\section{Regional surveys/monographs}

Moysiyenko, I.I., Khodosovtsev, A.Y., Pylypenko, I.O., Boiko, M.F., Malchykova, D.S., Klymenko, V.M., Ponomarova, A.A., Darmostuk, V.V. \& Zaharova, M.Y. 2020. Perspective nature protected objects of Kherson region. Helvetica, Kherson UA. DOI: 10.32782/978-966-992-049-2/1-166 (in Ukrainian)

Didukh, Y.P., Borsukevych, L.M., Davydova, A.O., Dziuba, T.P., Dubyna, D.V., lemelianova, S.M., Kuzemko, A.A., Kolomiychuk, V.P., Kucher, O.O., (...) \& Shyriaeva, D.V. 2020. Biotopes of Steppe zone of Ukraine. DrukArt, Chernivtsi, UA (in Ukrainian) pdf

\section{Contact persons:}

András István Csathó: csatho@verge.hu

Balázs Deák: debalazs@gmail.com

Iwona Dembicz: i.dembicz@gmail.com

Jürgen Dengler: juergen.dengler@uni-bayreuth.de

Anna Kuzemko: anyameadow.ak@gmail.com

Saifi Merdas: saifieco@gmail.com

Ivan I. Moysiyenko: ivan.moysiyenko@gmail.com

Orsolya Valkó: valkoorsi@gmail.com 


\section{Forthcoming Events}

$11^{\text {th }}$ International Conference on Ecological Informatics (ICEI:2020)

17-21 November 2020, Thiruvnanthapuram, India

Event website: https://www.iiitmk.ac.in/cvrlei/icei2020/index.html

$15^{\text {th }}$ EDGG Field Workshop:

May 2021 South Ukraine

FW webpage https://edgg.org/fieldworkshop2020

$64^{\text {th }}$ Symposium of the International Association for Vegetation Science (IAVS)

28 June -3 July 2021, Madrid, Spain

$30^{\text {th }}$ International Congress for Conservation Biology (ICCB) 2021

18-22 July 2021, Kigali, Rwanda

Conference website: https://conbio.org/mini-sites/iccb-2021

$17^{\text {th }}$ Eurasian Grassland Conference: Grassland dynamics and conservation in a changing world

September 2021, Tolosa, Spain

Conference webpage https://edgg.org/egc2020 $29^{\text {th }}$ Workshop of the European Vegetation Survey (EVS) 26-30 September 2021, Roma, Italy

$30^{\text {th }}$ Workshop of the European Vegetation Survey (EVS) Spring 2022, Bratislava, Slovakia

$16^{\text {th }}$ EDGG Field Workshop:

Summer 2022, South Tyrol (Vintschgau, Veltlin, etc.), Italy

$18^{\text {th }}$ Eurasian Grassland Conference

Summer 2022, Hungary

$31^{\text {st }}$ Workshop of the European Vegetation Survey (EVS)

May 2023, Kyiv, Ukraine,

$17^{\text {th }}$ EDGG Field Workshop

Summer 2023, Picos de Europa, Northern Spain

$19^{\text {th }}$ Eurasian Grassland Conference

Late summer 2023, Bolzano, Italy

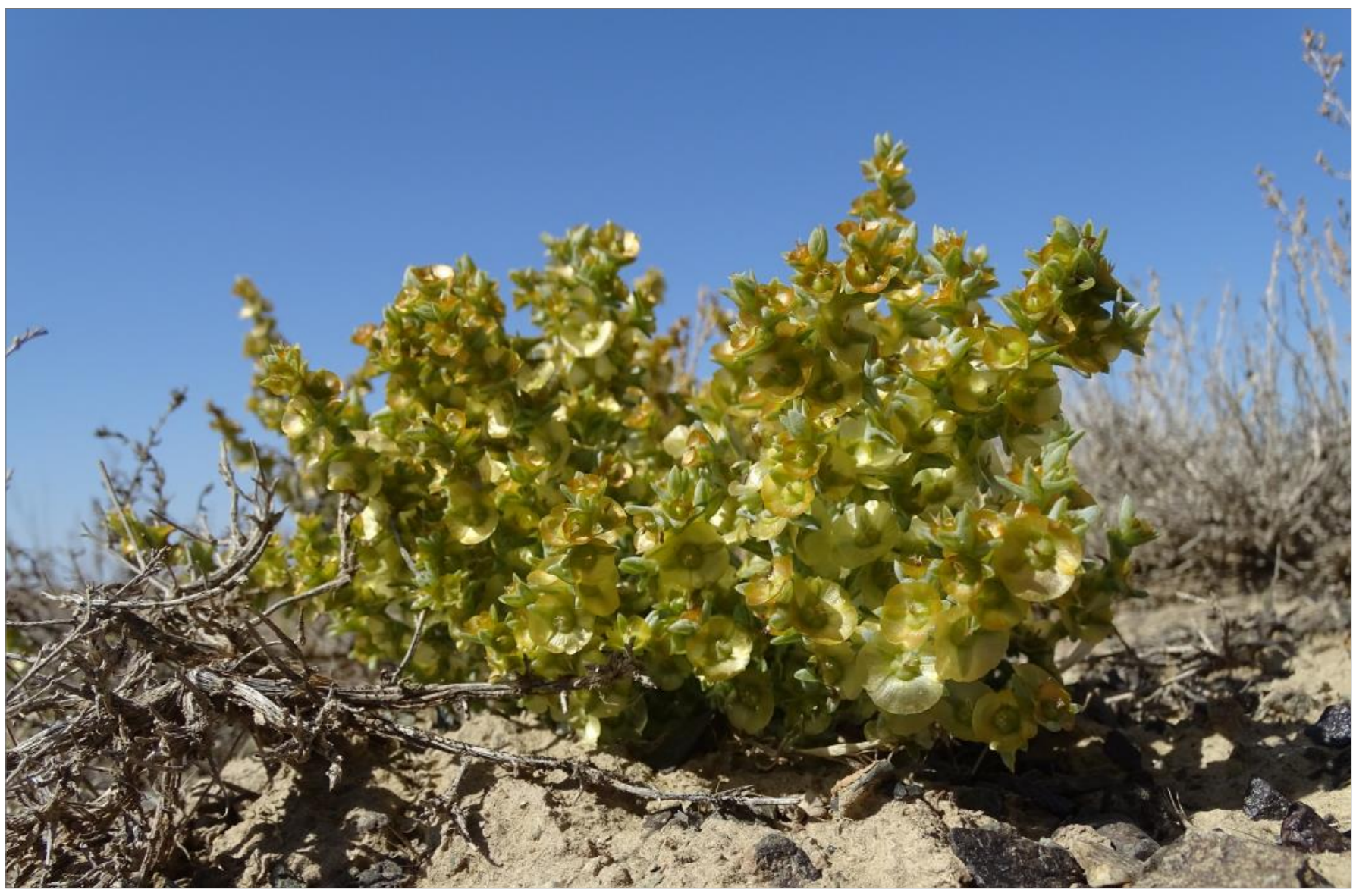

Climacoptera crassa in desert steppe. Almaty Province, Kazakhstan. Photo: I. Smelansky. 


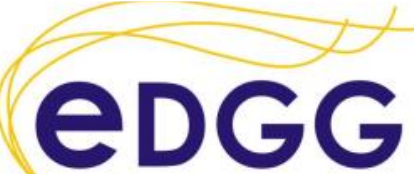

Grass|ลกd] research and conservation
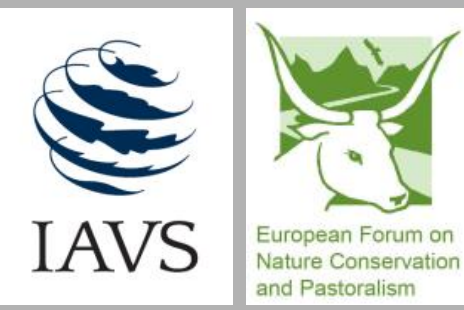

EDGG on the web:

http://www.edgg.org

EDGG in Facebook:

https://www.facebook.com/groups/938367279561202

EDGG on the ResearchGate

https://www.researchgate.net/project/EDGG-Eurasian-

DryGrassland-Group

The Eurasian Dry Grassland Group (EDGG), founded in 2008, is a working group of the International Association for Vegetation Science (IAVS) and member of the European Forum on Nature Conservation and Pastoralism (EFNCP). On 26 October 2020, it had 1339 members from 64 countries.

The Eurasian Dry Grassland Group (EDGG) is a network of researchers and conservationists interested in any type of Palaearctic natural and semi-natural grasslands. It is an official subgroup of IAVS (http://www.iavs.org) but one can join our group without being an IAVS member. We live from the activities of our members. Everybody can join the EDGG without any fee or other obligation.

The EDGG covers all aspects related to grasslands, in particular: plants - animals - fungi - microbia - soils - taxonomy - phylogeography - ecophysiology - population biology - species' interactions - vegetation ecology - syntaxonomy - landscape ecology - biodiversity - land use history - agriculture - nature conservation - restoration - environmental legislation - environmental education.

\section{EDGG Executive Committee and responsibilities of its members}

Alla Aleksanyan, Armenia, alla.alexanyan@gmail.com Chief Editor of the Website; Deputy Conference Coordinator; member of the Editorial Board of Palaearctic Grasslands

Didem Ambarlı, Turkey \& Germany, didem.ambarli@gmail.com

Conference Coordinator; Deputy Chief Editor of the Website; member of the Editorial Board of Palaearctic Grasslands

Idoia Biurrun, Spain, idoia.biurrun@ehu.es

Membership Administrator; Deputy Chief Editor of Palaearctic Grasslands; Deputy Field Workshop Coordinator

Jürgen Dengler, Switzerland, dr.juergen.dengler@gmail.com

Secretary-General; Coordinator for Special Features; Deputy Chief Editor of Palaearctic Grasslands
Iwona Dembicz, Poland, i.dembicz@gmail.com

Field Workshop Coordinator; member of the Editorial Board of Palaearctic Grasslands

Anna Kuzemko, Ukraine, anyameadow.ak@gmail.com Chief Editor of Palaearctic Grasslands; Deputy Facebook Group Administrator

\section{Péter Török, Hungary, molinia@gmail.com}

IAVS Representative and Treasurer; Deputy Coordinator for Special Features; Deputy Secretary-General; member of the Editorial Board of Palaearctic Grasslands

\section{Stephen Venn, Finland, stephen.venn@helsinki.fi} Facebook Group Administrator; member of the Editorial Board of Palaearctic Grasslands; Deputy Conference Coordinator

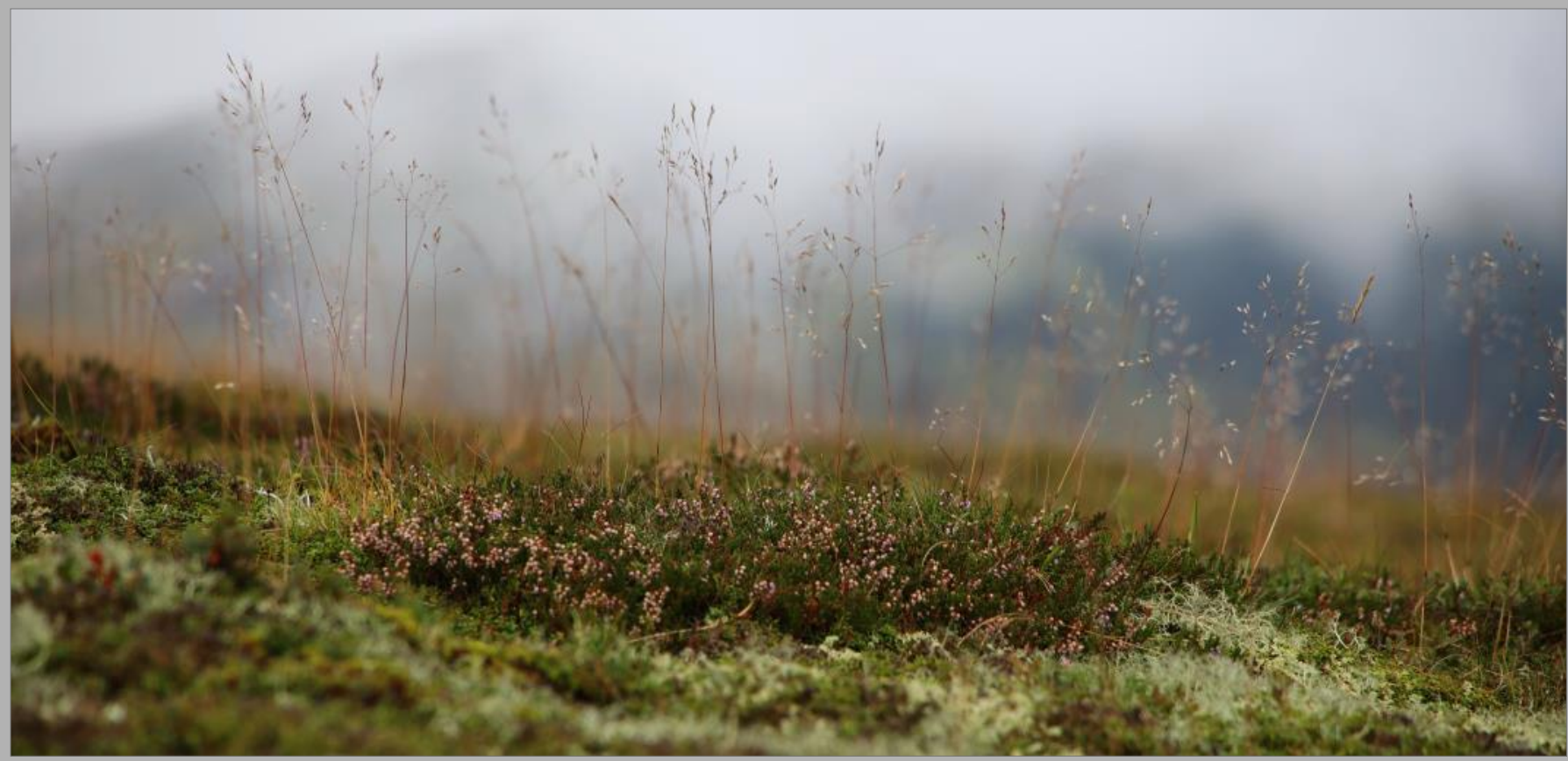

Avenella flexuosa in an alpine heathland community (Loiseleurio-Cetrarietum) consisting of Calluna vulgaris, Loiseleuria procumbens and numerous lichen species (i.e. Cladonia spp. and Cetraria spp.). Koralpe at $1850 \mathrm{~m}$ a.s.l. (at the border of Styria and Carinthia Southern Austria). Photo: P. Sengl. 